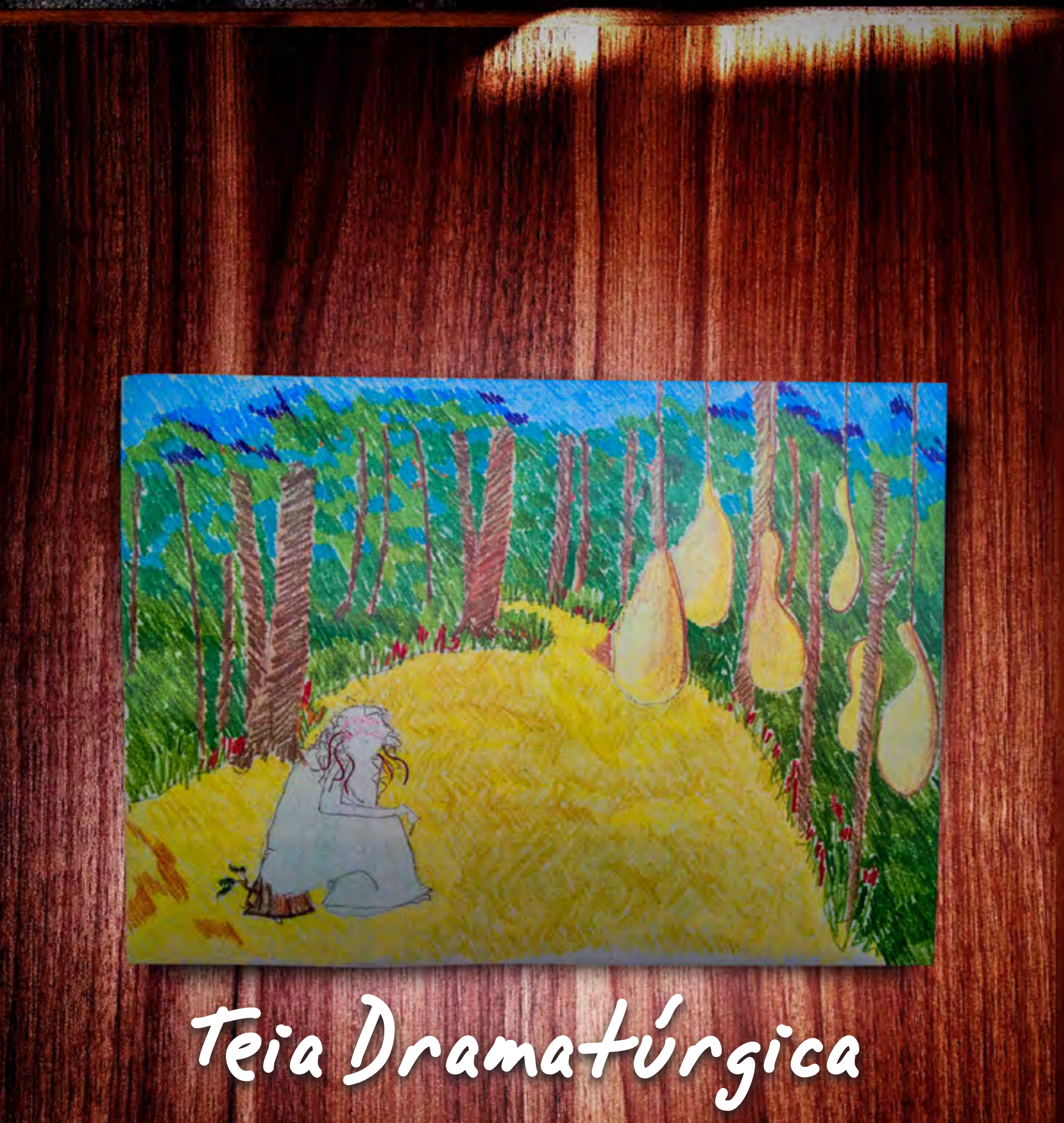

\title{
Trajetos sinuosos de uma atriz em fluxo e ritmo criativos
}

RENATA VENDRAMIN 
Universidade de São Paulo

Escola de Comunicação e Artes

Departamento de Artes Cênicas

\section{Teia Dramatúrgica}

\section{Trajetos sinuosos de uma atriz em fluxo e ritmo criativos}

RENATA VENDRAMIN

Dissertação apresentada ao Programa de Pós-graduação em Artes Cênicas,

Área de Concentração Pedagogia do Teatro, Linha de Pesquisa Formação do Artista Teatral, da Escola de Comunicação e Artes da Universidade de São Paulo, como um dos requisitos para a obtenção do título de Mestre em Artes Cênicas, sob a orientação do Prof. Dr. Eduardo Tessari Coutinho. 
Autorizo a reprodução e divulgação total ou parcial deste trabalho, por qualquer meio convencional ou eletrônico, para fins de estudo e pesquisa, desde que citada a fonte.

Catalogação na Publicação

Serviço de Biblioteca e Documentação

Escola de Comunicações e Artes da Universidade de São Paulo Dados fornecidos pelo(a) autor(a)

Vendramin, Renata

Teia Dramatúrgica: : trajetos sinuosos de uma atriz em fluxo e ritmo criativos / Renata Vendramin. -- São Paulo: R. Vendramin, 2015.

204 p.: il. + 2 DVDs.

Dissertação (Mestrado) - Programa de Pós-Graduação em Artes Cênicas - Escola de Comunicações e Artes / Universidade de São Paulo.

Orientador: Prof. Dr. Eduardo Tessari Coutinho

Bibliografia

1. Teatro 2. Trabalho do ator 3. Corpovoz 4. Cocriação 5. Pensamento sistêmico I. Coutinho, Prof. Dr. Eduardo Tessari II. Título.

CDD 21. ed. -792 
Dissertação defendida em de de 2015 .

Banca Examinadora 


\section{Respiro}




\section{DEDICATÓRIA}

À minha mãe Marilza Beraldi Vendramin, ao meu pai Lúcio Vendramin (que já cocriamundos em outro plano), aos meus irmãos mais velhos Márcio e Mariane Vendramin, e, através deles, a todas às VOZESINSPIRADASEINSPIRADORAS que são os fios da teia da vida.

Às minhas avós Ana Storto Beraldi e Lúcia Cardonha Vendramin.

Às minhas bisavós Rosa Tonhão Storto, Páscoa Santezzi Beraldi, Concheta Cardonha e Isabel Casanova Vendramin.

Às minhas tataravós...

À vó da vó da vó da vó da vó da vó

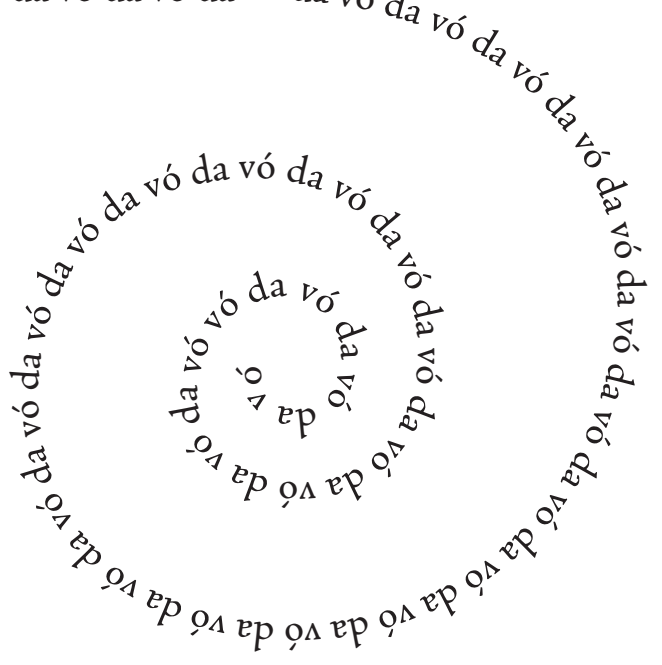


No saber da experiência não se trata da verdade do que são as coisas, mas do sentido ou do sem-sentido do que nos acontece. E esse saber da experiência tem algumas características essenciais que o opóem, ponto por ponto, ao que entendemos como conbecimento. Se a experiência é o que nos acontece e se o saber da experiência tem a ver com a elaboração do sentido ou do sem-sentido do que nos acontece, trata-se de um saber finito, ligado à existência de um indivíduo ou de uma comunidade bumana particular; ou, de um modo ainda mais explícito, trata-se de um saber que revela ao homem concreto e singular, entendido individual ou coletivamente, o sentido ou o sem-sentido de sua própria existência, de sua própria finitude. Por isso, o saber da experiência é um saber particular, subjetivo, relativo, contingente, pessoal. Se a experiência não é o que acontece, mas o que nos acontece, duas pessoas, ainda que enfrentem o mesmo acontecimento, não fazem a mesma experiência. $O$ acontecimento é comum, mas a experiência é para cada qual sua, singular e de alguma maneira impossivel de ser repetida. O saber da experiência é um saber que não pode separar-se do individuo concreto em quem encarna. (BONDÍA, 2002, p. 27)

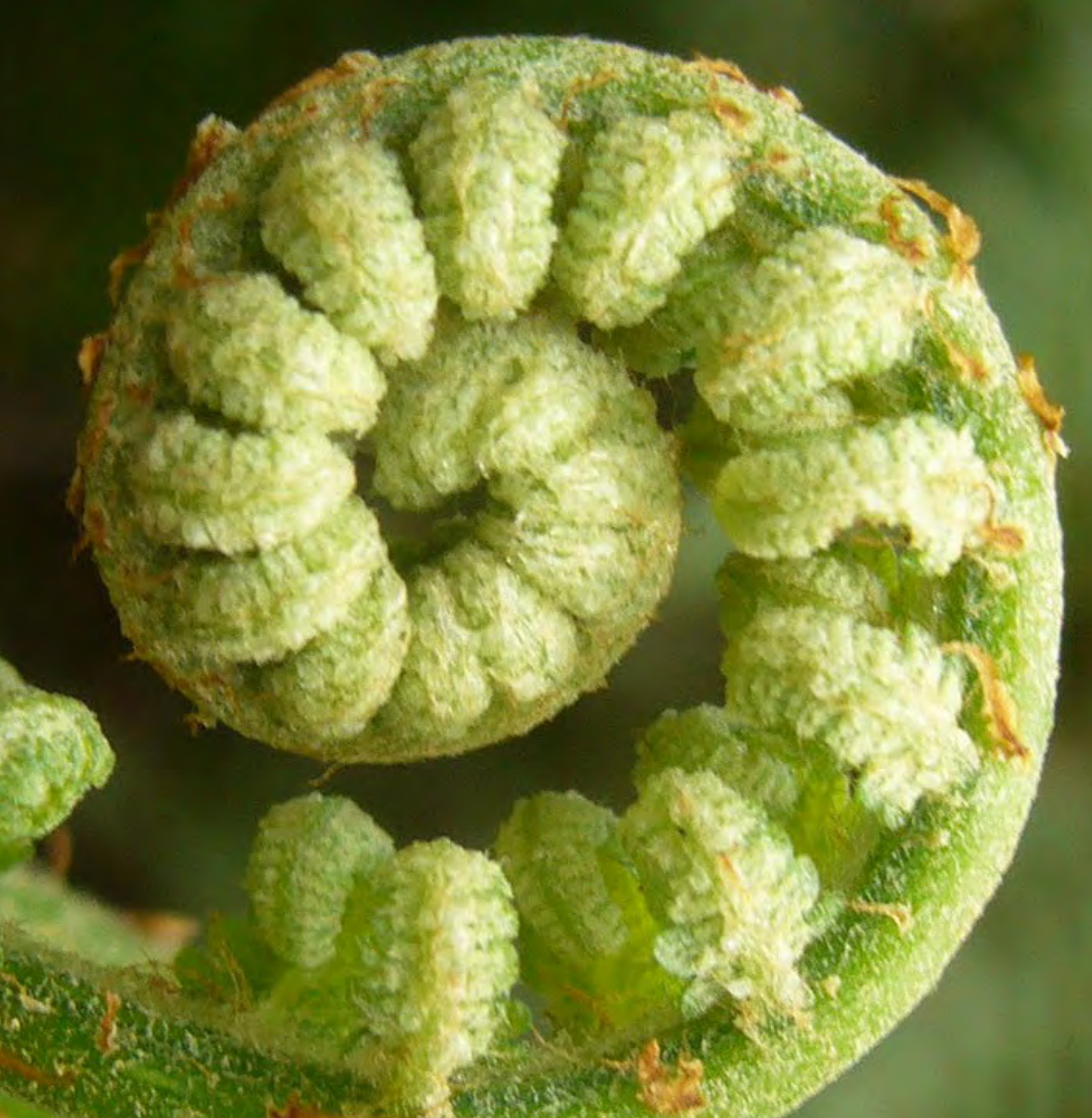




\section{RESUMO}

Essa é uma narrativa poéticoinvestigativa em que compartilho os caminhossaberesexperiênciasconhecimentos cocriados durante a feitura da peça teatral A Próxima História, pelo grupo AIvU Teatro, através da minha voz, uma das artistascocriadoras que vivenciou esse sistemaprocesso. A cada respiração dessa pesquisaexperiência, crio e recrio-me artistacocriadorapesquisadoraeducadora. Convido a todos a uma experiência de leitura que se fia no passo do caminhar, que cocriamundos em relação, que convoca o nosso SERSERPENTE - aquele sinuoso, fluido, conectivo, sensível, sistêmico, para pulsar em fluxo e ritmo criativos.

Palavras-chaveः teatro, trabalho do ator, corpo, voz, corpovoz, cocriação, pensamento sistêmico, cena contemporânea.

\section{ABSTRACT}

This is a poetic/investigative narrative which I share paths/knowledge/ experiences co-created during the making of the play A Próxima História with AIvU Theatre. Through my voice, one of co-creator/artist who experienced this system/process. Each single breath in that research/experiment, I have been creating and recreating myself as co-creator/researcher/educator/ artist. I invite everyone to a reading experience that weaves itself on a single walking step in relationship which co-create/worlds, summoning our BEING/SERPENT - that sinuous, fluid, connective, sensible, systemic, to pulse in flow and in a creative rhythm.

Keywords: theater, actor's work, body, voice, body/voice, co-creation, systemic thinking, contemporary scene. 



\section{TRAUKTÓKIA}

Faixa 01: Cobra Rasteira ${ }^{1}$

DVD 01 / Faixa 01

Caminhante em Escuta - 10

Bailarina Cocriadorademundos - 14

Convite à Experiência de Leitura - 15

PRIMEIRO CICLO:

O Antes do Antes de Antes... - 20

Primeiros Passos - 30

Encarnando - 44

A Chegada de Artistascocriadoras - 78

\section{O PONTO DE MUTAÇÃO:}

Movimentos de Transição - 92

Renascimento - 97

\section{SEGUNDO CICLO:}

Célula 1 - Prólogo - 108

Célula 2 - A Mais Velha que o'Tempo - 112

Célula 3 - Ecos do Mundo - 132

Célula 4 - Soluções Inúteis - 137

Célula 5 - Infância - 150

Célula 6 - Imaginamentos - 168

Célula 7 - Música Instrumental A Próxima História - 174

A Organização da Teia Dramatúrgica - 176

Parto... - 196

Agradecimentos - 201

Referências Bibliográficas - 203 


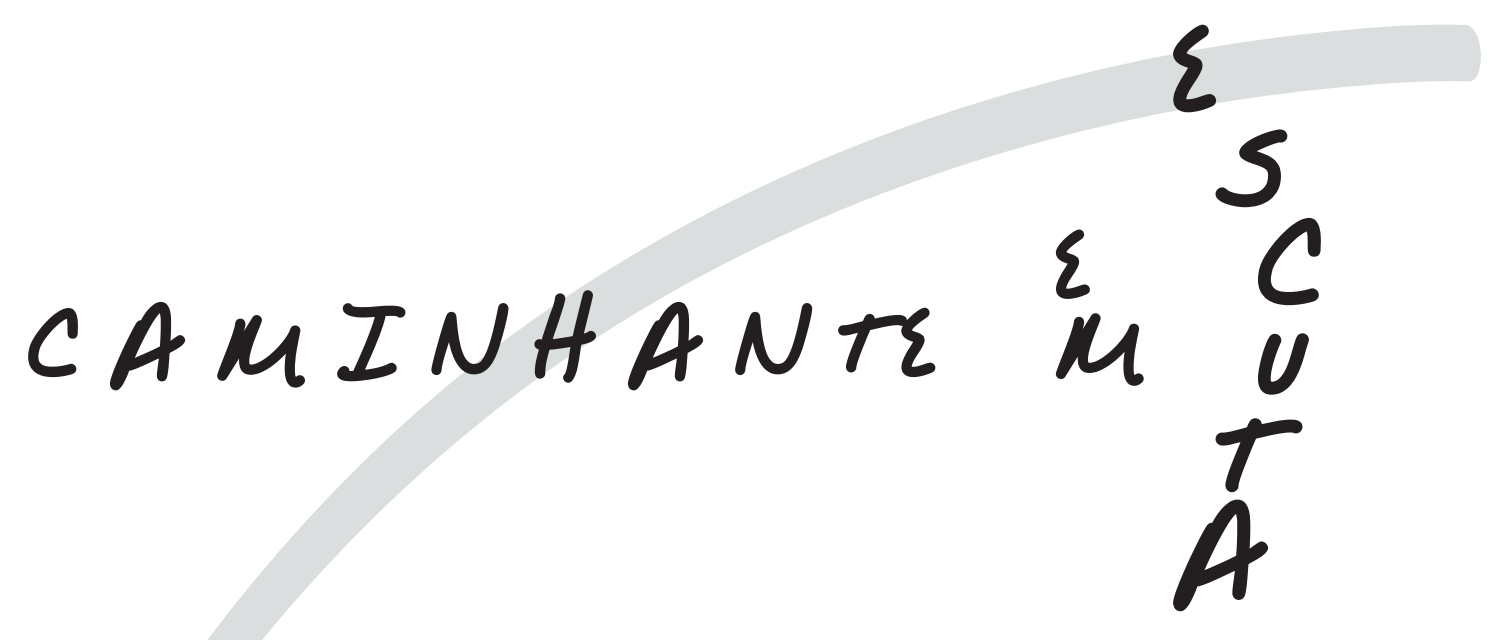

'Eu sou um outro você'?

Eu nasci pássaro solto como todo ser humano. $\mathrm{L} i \mathrm{v} \mathrm{r}, 1 \mathrm{i} \mathrm{v} \mathrm{e}, 1 \mathrm{i} \mathrm{v} \mathrm{r}$ e.

Com os pés no chão, o cabelo bagunçado pelo vento, comendo fruta gostosa tirada fresquinha da árvore e rolando com os bichos no quintal, comecei a bailar com o mundo.

Desde sempre fui uma meninaDESEJ An 6 G. Desejante de conhecer, de aprender, de experimentar, de inventar as coisas. Desde cedo tive um gosto especial por conhecer... conhecer o sentido e semsentido das coisas. Mais do que saber o que eram e como funcionavam, inquietava-me saber por que as coisas existiam e por que as pessoas faziam as coisas...

A meninaDFSEJdntG, que gostava de conhecerexperimentarin a sua criatividade brincando: dançava, cantava, inventava teatros, shows, alegorias e botava todos os familiares e amigos para participar (às vezes obrigava, confesso!), também desenhava, cozinhava, pintava, escrevia, fazia artesanatos que via na televisão com material improvisado que tinha em casa. Nem sempre dava certo, mas isso pouco importava para a menina.

A meninaDFSEJeAn 6 E encontrou uma maneira de existir que lhe parecia coerente, alegre, plena, necessária e essencial.

A menina não sabia disso na época em que vivia... usan ${ }_{d_{0} t_{O}}$

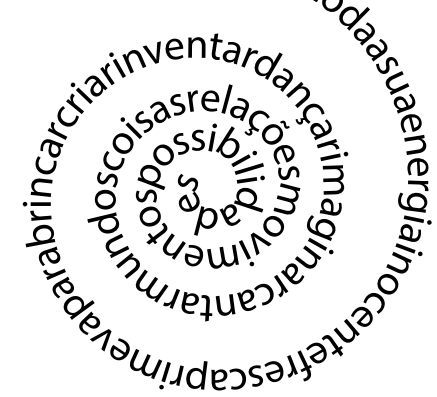

... ela só sentia que assim era gostoso viver. Assim dava gosto viver! E isso era o que importava.

Quando teve a oportunidade, a meninaDFSEJAnEG, já uma moça de 16 anos, saiu da pequena cidade do interior para descobrir outras possibilidades de ser, existir, pensar, agir, sentir, criar, aprender, amar... Foi morar na capital. 
A vida da meninaMocaDFSEJ⿻ In contos de fadas clichês não existem e que são tediosos, previsíveis e perigosos! Ela começou a perceber que as perguntas que para ela eram tão essenciais (Por que as coisas existem? Por que as pessoas fazem as coisas?) pareciam não importar muito para a maioria das pessoas adultas que eram responsáveis por criar o mundo em que ela existia. O mundo que ela era! Em algum lugar de si a meninaMocaDPSEJAn $\mathbf{E}$ sabia que a sua habilidade de criar e manifestar a sua criatividade eram o único caminho possível.

\section{PKA RKUMAVIDA QUEDÁ GOSTO DEVIVER, SABL?!?}

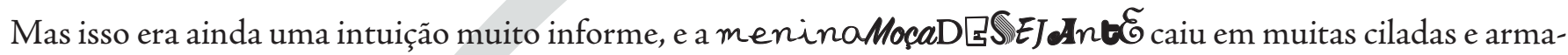
dilhas, embarcou em muitos padrões que - descobriu, mais tarde - não faziam nenhum sentido para si.

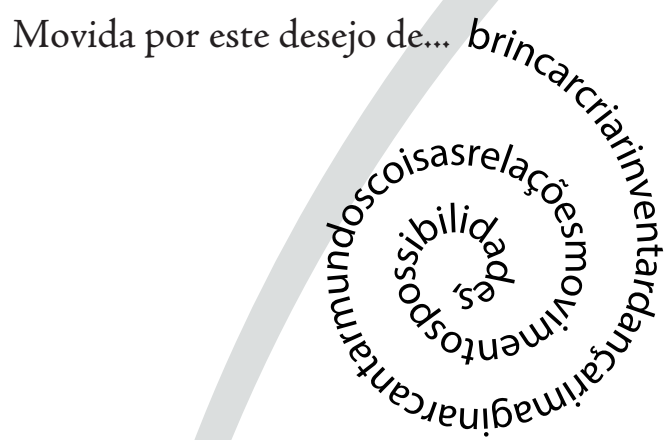

...aquele que estava com ela desde que ela encarnou lá na cidadezinha do interior, a meninaMocaDFSEJdntE foi tecendo seus cominhos $\triangle \mathrm{NU} O S O S$ de aprendizado: o jornalismo, o cinema, o teatro, a dança, o canto, o yoga, a percussão, a capoeira... experimentando, durante a sua existência, todas as modalidades de $m o$ vi me n to a que teve acesso, entrelaçando-as... e através delas, reinventando-se.

Mesmo nos momentos (que não foram poucos!) em que as escolhas que fez levaram-na a ter uma vida em

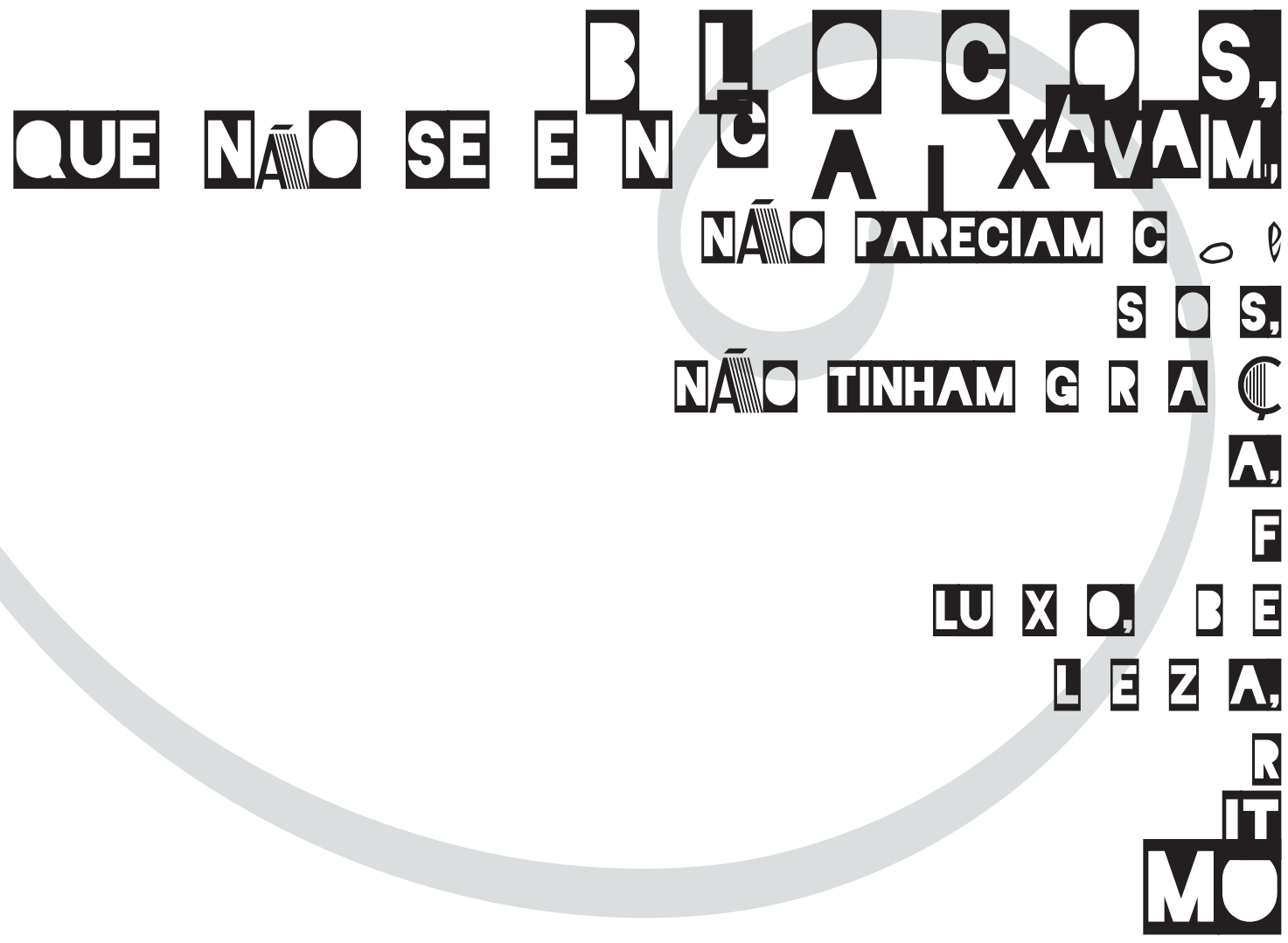


mesmo assim, mesmo blocada, a faísca da meninaDFSEJAn va-se em um átimo de criatividade, de luz, de intuição, de fractal, que a faziam encontrar outra possibilidade de caminho. Às vezes, é verdade, ela teve de chegar a lugares-limite de fragmentação, de ausência de sentido, para reencontrar o caminho da interconexão.

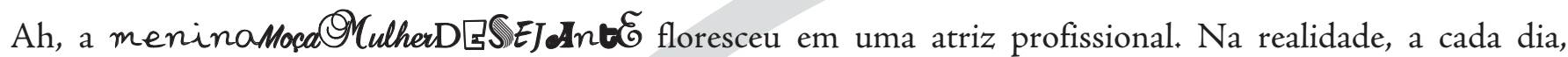
a cada respiração, ela experimenta um pouco mais a artistacriadora que se manifesta nela e através dela. Ser atriz é apenas um dos seus desdobramentos.

Nas suas andanças desejantesinuosas, ela encontrou com diferentes qualidades de conhecimento pelas quais tem enorme respeito e gratidão.

TNHO RESFEITO POR TODA QUALIDADEDE CONHECIMENTO QUE EXIST.

Ela encontrou, para além do conhecimento intelectual ofertado nas escolas, colégios, universidades, faculdades, academias - lugares na nossa cultura que reconhecemos como os espaços onde adquirimos conhecimento -, com o saberes das tradições populares, orais, como a indiana, a xamânica, a africana, a da sua família de pessoas do campo... ela deleitou-se no encontro com o outro, misturou-se com os seus fluxos, cheiros, ritmos, gostos, pensamentos, a ponto de borrar seus limites e criar novas fronteiras. Todos esses conhecimentosexperiênciassaberes pulsam na meninaMosa OM (uherDFSEJdn $\mathbf{E}$, fazem-na pulsar. Fizeram com que ela encontrasse um caminho que desse gosto de viver!

A meninaMoca M (ulherDESEJAn $\mathbf{E}$ E sempre achou, e continua acreditando, que todas essas possibilidades de conhecimento estão interligadas, complementam-se em sua diversidade e fazem parte de uma rede de conhecimento que está disponível para todos terem acesso.

UMA REDEDE CONHECIMENTO PRA VIDA DAR GOSTO DEVIVER!

Faz pouco tempo, numa encruzilhada das suas andançaserpentes, a meninaMosa OM (ulherDFSEJdn6 decidiu ingressar no mestrado do programa de Artes Cênicas da Universidade de São Paulo. Uma escolha muito intuitiva. $\mathrm{O}$ que tinha para iniciar essa trajetória era a sua experiência de artistacriadora e aquele

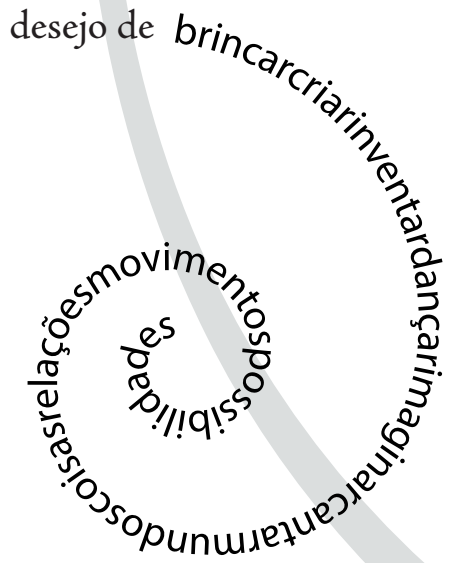

Ela fez uma prova, passou. Fez outra, passou. Mais uma entrevista, foi boa. Um passo por vez, respirando, deu certo. Começou.

O planejamento desde sempre foi $c$ a $m$ $\quad \begin{array}{llllll}n & b & a & r\end{array}$. Seguir caminhando, pois o conhecimento necessário apresenta-se para o caminhante em escuta. 
O mestrado para mim é caminhada, é risco, é o desconhecido, é cocriação, é processo, é um certo tempo que dura.

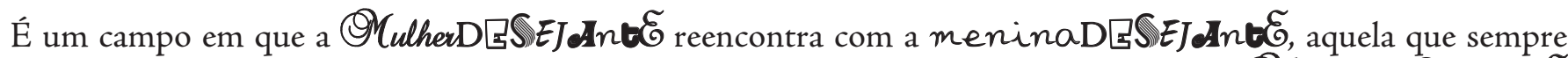

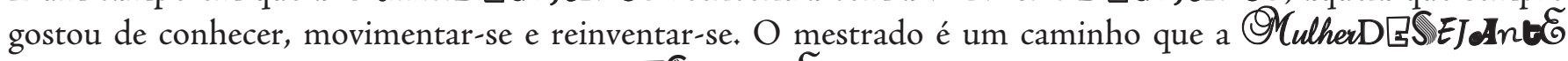
encontrou para deixar viva a sua meninaDFSEJAntE.

E trilhando esse caminho a meninaMosa (M (uherDFSEJdn cubro a cada passo, a cada respiração, que o mais importante não é o que se deseja, mas seguir desejante, pois é essa

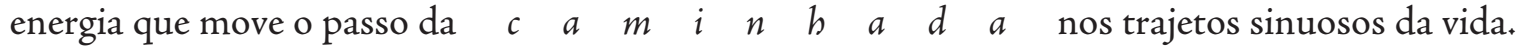

$\mathrm{E}$

o

ESSENCIAL

é

s e guir

b

a

i

1

a

n

d

o

criando

e

recriando

os

${ }^{c} a$

h ${ }_{\mathrm{n}}^{\mathrm{o}}{ }_{\mathrm{i}}^{\mathrm{m}}$ 


\section{BAILARINACOCRIADORADEMUNDOS}

Que pesquisadora é esta capaz de dissolver o seu ponto de vista no campo de investigação?

Capaz de mover-se com o campo em um movimento implicadoexplicado?

Que pesquisadora é esta capaz de vir a ser em um solo fecundo?

Capaz de ouvir, intuir, silenciar, até o limite de perder-se de si e encontrar-se no outro?

Que pesquisadora é esta, mais artista que cientista, capaz de recriar-se na criação?

Capaz de perceber e imaginar mundos com o frescor, a curiosidade e a inocência de uma criança?

Que pesquisadora é esta capaz de lançar-se no caos por amor e consciência?

Capaz de viver perguntas sem espremer respostas?

Que pesquisadora é esta que corre o risco de ser o fluxo?

Capaz de habitar uma região de transpasse, de deslocamento, de transformação?

Que pesquisadora é esta capaz de ser múltiplas, zona de entrelaçamento?

Capaz de fabular a vida para reinventar as relações?

BAILARINACOCRIADORADEMUNDOS
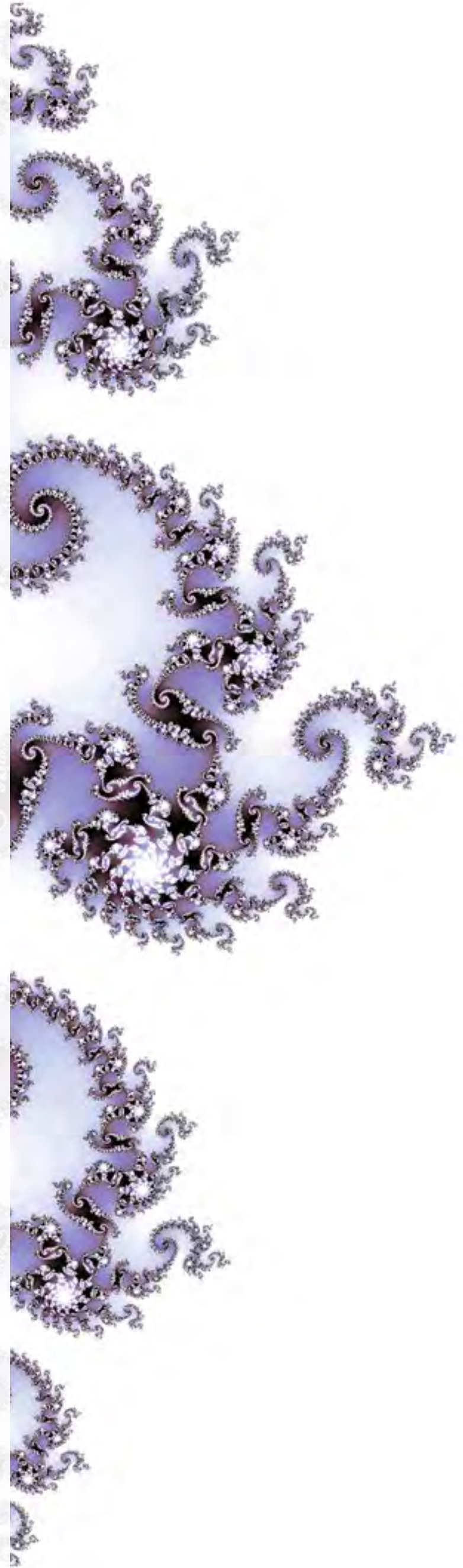


\section{Convite}

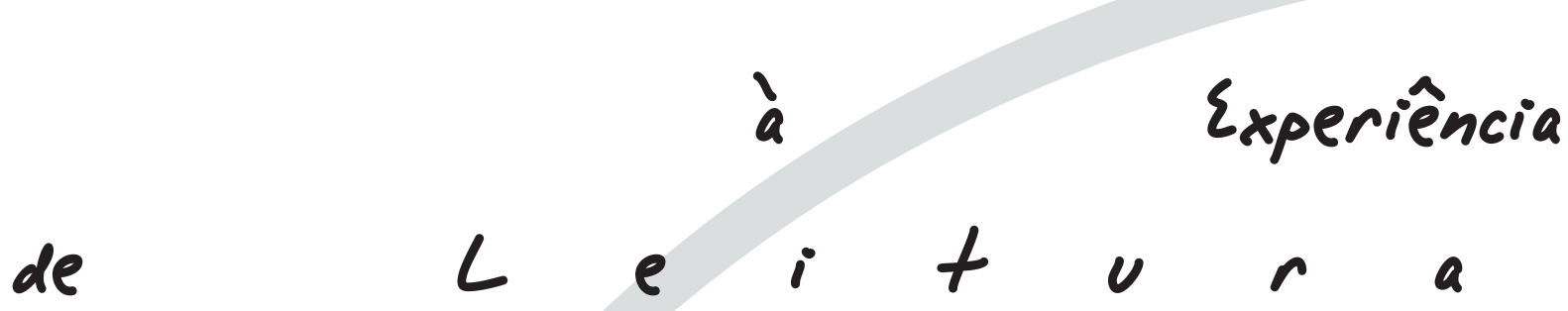

$\begin{array}{lllllllll}\text { A trajetória sinuosa e sistêmica dessa pesquisaexperiência não conseguiria } & R & E & S & P & I & R & A & R\end{array}$ dentro de padrões de escrita muito rígidos e/ou lineares. As múltiplas interconexões dos fios dessa teia precisam

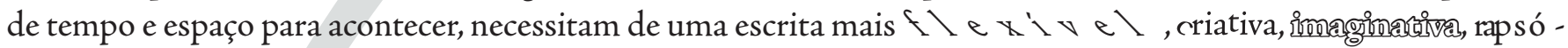
d i c a , de entrehạmento, em que o próprio padrão da escrita nasça da experiência vivida.

A experiência da escrita dessa dissertação foi também uma trajetória sinuosa e sistêmica cocriadora por inúmeras vozes poéticas e teóricas, que se construiu conforme eu caminhava. Desde o início, gostaria que o contato com esse texto criasse um espaçotempo para uma $E_{X}$ PERIÊNCIA ${ }_{D E} L^{E} I^{T} U^{R} A$.

Para que o texto, então, se expandisse para além das palavras, experimentei dar tempo e espaço a ele: brincando com espaços em branco, dando mais espaço entre um parágrafo e outro, descolando palavras e frases dos parágrafos, mexendo nos tamanhos e formas das fontes, criando um entrelaçamento das notas de rodapé, dando movimentos e ritmos para que o texto ressoasse e compartilhasse a experiência vivenciada durante os dois últimos anos. Foi como compor uma partitura musical ou corporal, ou ainda outra peça teatral, para além de A Próxima História - obra artística que é semente e fruto dessa pesquisaexperiência de mestrado. Um trabalho que se iniciou na minha escrita solitária e ganhou contornos mais definidos na cocriação com o designer Marcelo Tomasini que fez a diagramação do texto. Experimentamos possibilidades para deixar o...

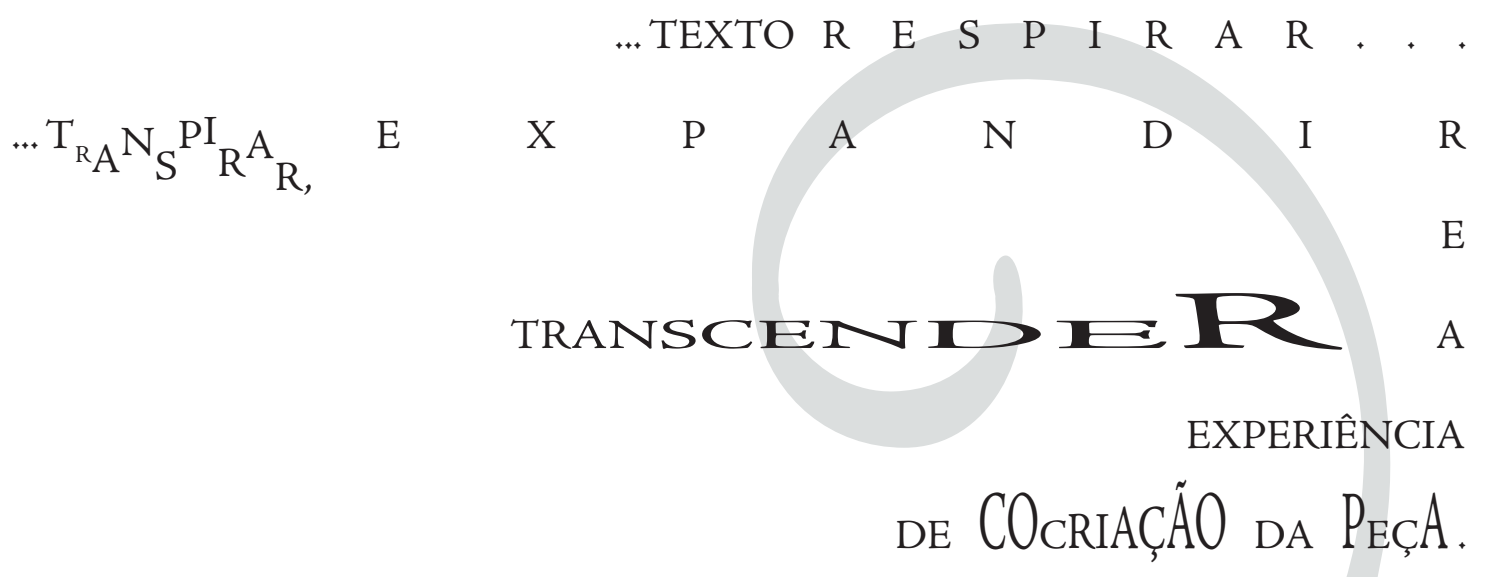

Os entrelaçamentos aconteceram de maneira orgânica. Entrelacei relatos das artistascriadoras, áudios de músicas (vozes de artistas que se conectaram à pesquisa), vídeos do sistemaprocesso, imagens que traziam texturas e cores que sensibilizassem nossas qualidades perceptivas. Na RELAÇÃO ENTRE ESSES ELEMENTOS, os sentidos e semsentidos da narrativa criaram-se, experimentando um equilíbrio dinâmico entre o investigativo e o poético. Mais do que aprofundar um ou outro elemento trazido no texto, interessava-me fortalecer as relações e os sentidos e semsentidos que nascem das conexóes dos fios dessa teia. 
A escrita que se cocria nessas páginas é um convite à ESCUTA, a uma experiência que é visual, sonora, tátil, sensorial, que visa colocar você EM RELAÇÃO a uma experiência que ocorreu durante um certo tempo que durou, com todos os seus ciclos e movimentos dinâmicos. Este não é um texto em que se leem alguns parágrafos de alguns capítulos e se consegue entender mais ou menos o que o autor quis dizer ou explicar, ou aonde ele pôde chegar; pelo contrário, é um convite a dar-se tempo e espaço, a experimentar uma relação,

\section{$\begin{array}{llllllllllllll}\mathrm{R} & \mathrm{E} & \mathrm{S} & \mathrm{P} & \mathrm{I} & \mathrm{R} & \mathrm{A} & \mathrm{R} & \mathrm{M} & \mathrm{O} & \mathrm{S} & \mathrm{UNNTOS}\end{array}$ a COCRIARMOS SERTIIDOS E SEMSERTIIDOS JUNTOS}

Durante a cocriação dessa narrativa ocorreu-me uma provocação, que é também feita a mim, artistapesquisadora que cocria essa pesquisaexperiência: decidi usar as palavras "atriz(es)" ou "artista(s)criadora(s)", no feminino, para designar todas as pessoas que compóem o sistemaprocesso, independente do gênero, quando me referir ao coletivo ou ao trabalho da atriz de maneira genérica ${ }^{3}$. Uma provocação para balançar e balancear nosso equilíbrio dinâmico das forças femininas (WWNN) e masculinas (YANG). Qual a sensação interna que isso traz a você? A mim, a primeira sensação foi de estranhamento, de algo estar errado, incorreto. Depois senti uma espécie de libertação, outra possibilidade de existir, mais flexível. Senti movimentos internos em meu cérebro.

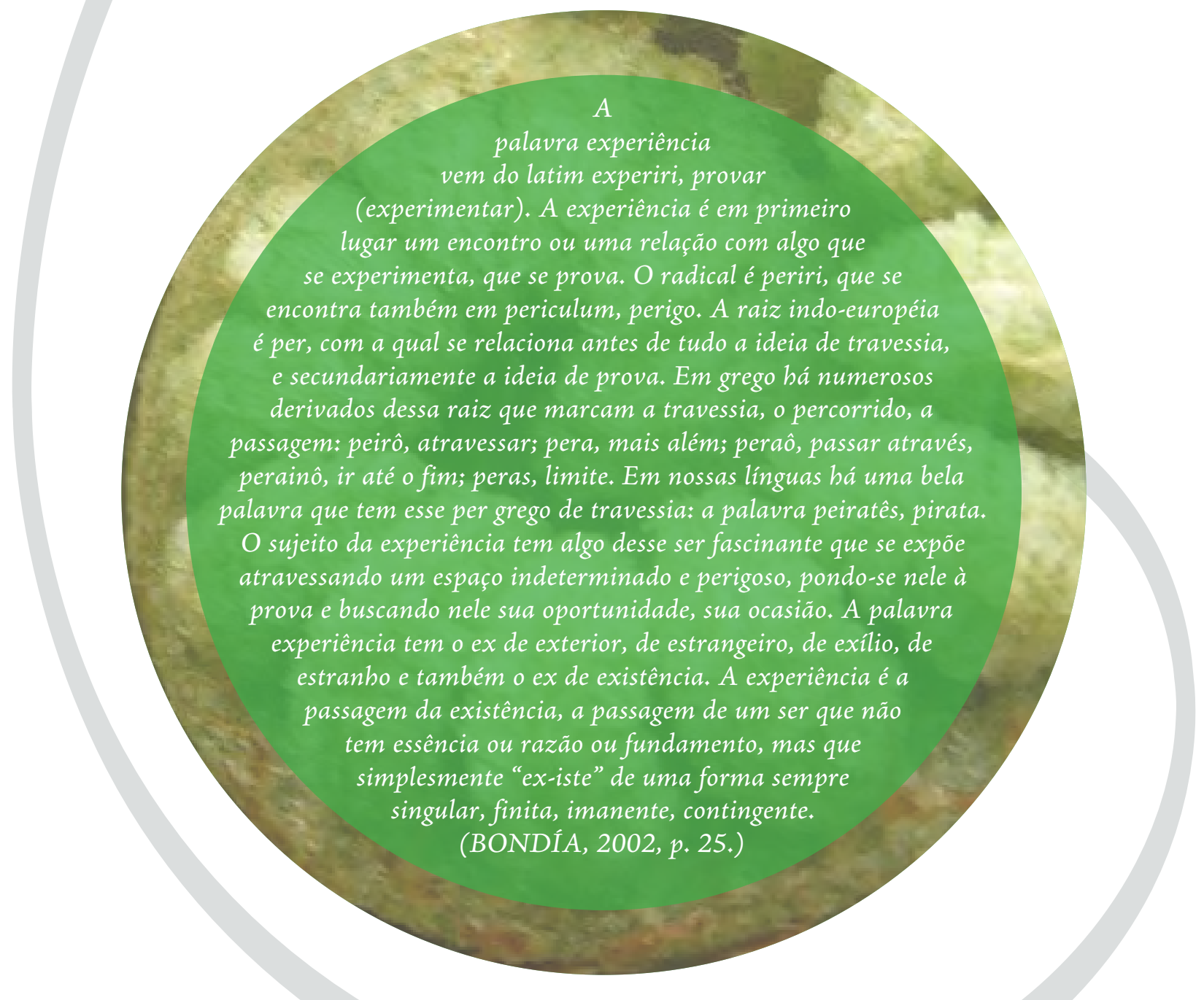

${ }^{3}$ Fritjof Capra, no livro O Ponto de Mutação, utiliza, alternadamente, os pronomes sua ("her") e seu ("his") para designar palavras que tanto podem se referir a mulher ou homem, como o termo pessoa. Ele comenta em uma nota de rodapé: "Penso ser essa a melhor maneira de evitar ser sexista ou deselegante". (CAPRA, 1982, p. 76.) 
Assim como a peça de teatro que é semente e fruto dessa pesquisaexperiência de mestrado, essa narrativa poéticoinvestigativa pretende ser uma experiência em si e em relação. Eu poderia apresentar uma lista dos nomes das pessoasvozes que fiam essa teia junto comigo durante a trajetória. Mas, assim como a vida, que não vem com bula, contraindicações, manual ou explicações preliminares, a intenção é que os encontros se fiem e cocriem-se no passo da caminhada, em fluxo e ritmo criativos. Com amor e gentileza, convido quem ler esse texto a, se decidir seguir essa experiência de leitura, silenciar as vozes vorazes por linearidades, resultados, métodos, metas e conclusões, e abrir espaço para o seu $s^{e} r_{s}$ e $p^{p} e^{n} t e$, aquele sinuoso, flexível, conectivo, com uma coerência, sensibilidade, inteligência e fluxo de outra natureza.

Vale ressaltar ainda que a narrativa aqui entrelaçada e compartilhada é uma vOZ da experiência de cocriação vivenciada. Simplesmente e somente uma vOZ, com todo o valor e todas as limitações que isso significa. Cada uma das pessoas que foi e continua sendo esse sistemaprocesso contaria à sua maneira as experiências compartilhadas, ressaltando e propondo reflexões a partir daquilo que mais lhe gerou sentidos e semsentidos - inclusive, acredito, contradizendo-me, complementando-me, negando-me, questionando-me. Como autora dessa dissertação, tenho plena consciência de que tudo aqui passa por mim - pela minha memória, imaginação e atualidade -, não só pelos meus olhos, também pelos meus ouvidos, pela minha pele, meu olfato, pela minha intuição, pelo meu coração, meu fígado, meu baço, pelos meus valores, minhas emoções, minhas crenças, minha ética, minha espiritualidade.

Por último, gostaria de dizer que não prometo que a experiência, que já começou quando você se conectou a essa dissertação, seja maravilhosa, transformadora, reveladora, salvadora, transcendental, intelectualmente primorosa, que lhe traga as respostas que busca. Convido você, com amor e gentileza, a libertar-se dessas expectativas e projeções, e colocar-se, junto comigo, na atitude, no estado, na presença de um C A -

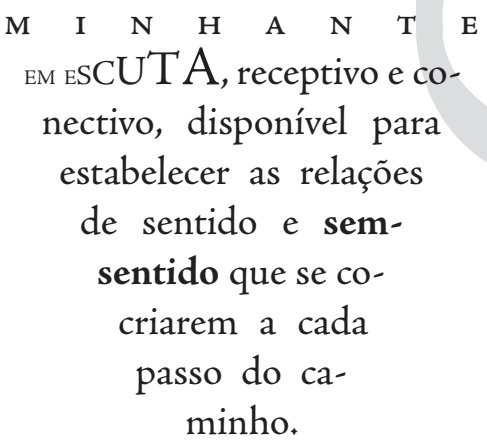




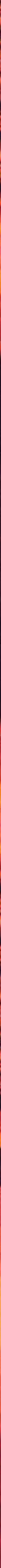




\section{DE ANTES}

Esta pesquisa começou antes do meu ingresso no mestrado e vai seguir para além dele, em movimento, em transformação, em evolução, em cocriação. Ela começou nos ensaios de um grupo, A I V U Teatro, no encontro de duas atrizescriadoras, Janaína Silva e eu, a partir de nossas intenções, desejos e paixões, da experiência de duas peças criadas anteriormente ${ }^{4}$, da vontade genuína de criar um terceiro trabalho, e com esse passo aprofundar o estudo e a investigação da nossa poética como grupo, bem como ter mais consciência da maneira como conduzimos nossos processos criativos. A investigação nasce da experiência. Revela-se necessária para o amadurecimento do trabalho criativo e artístico.

\section{Onde comegamos A Próxima História, pega que é, ao mesmo tempo, semente e fruto desta pesquisaexperiência de mestrado?}

Em um pequeno banco de madeira colocado no centro da sala de ensaio em finais de 2011, começo de 2012. Além do pequeno banco existia uma grande temática lançada no espaçotempo de cocriação: O R I G E M.

A escolha do banco poderia parecer simples demais, ou mesmo ingênua, para olhos com expectativas espetaculares, assim como a escolha do tema poderia soar pretensiosa ou complexa demais. Para nós eram escolhas cruciais, que diziam respeito à essência do trabalho e do nosso desejo de artistascriadoras. Para os nossos olhos, aquele não era somente um pequeno banco de madeira, ele era o nosso I A M Á.

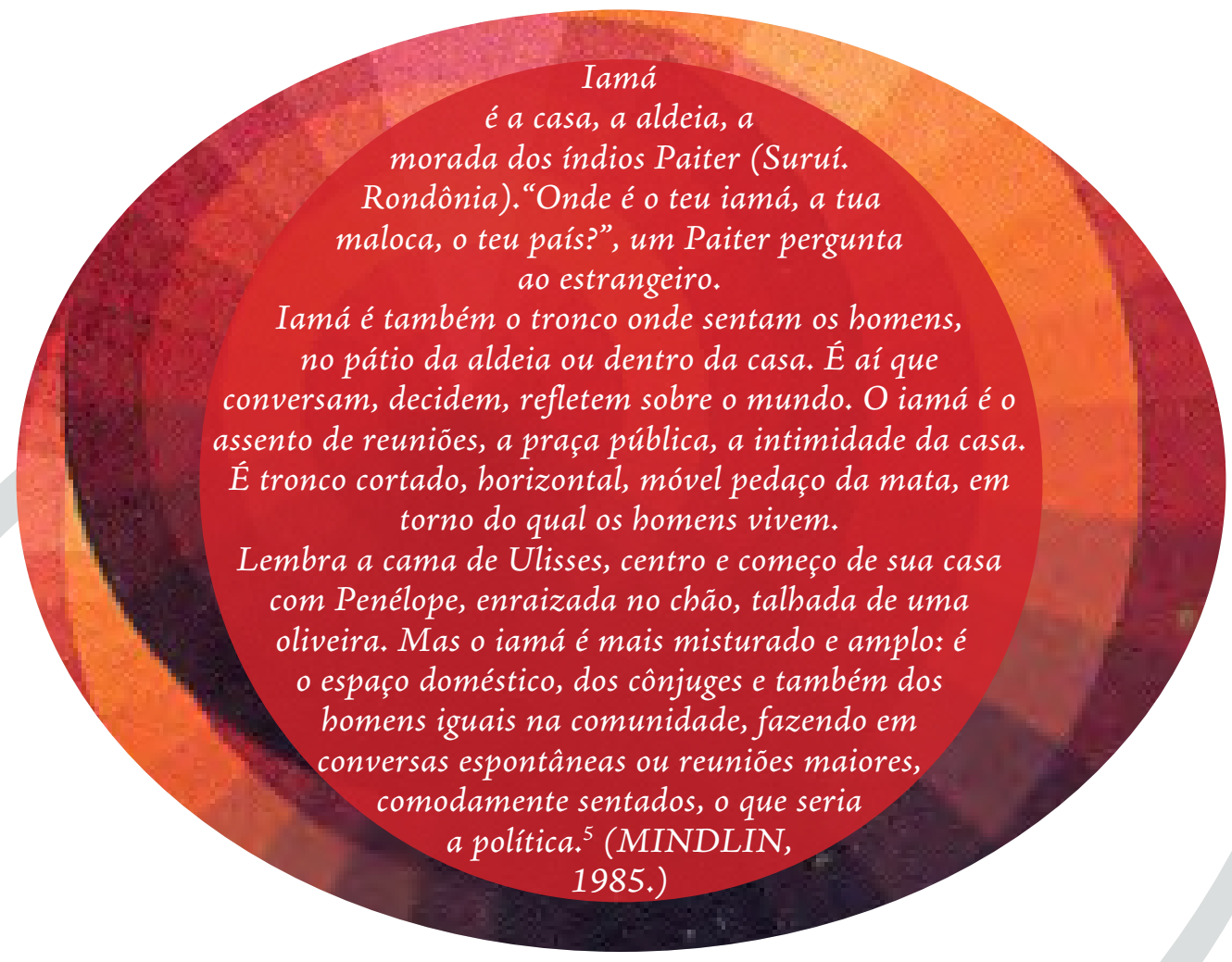

O fato de termos escolhido o iamá, elemento encontrado numa das tradições indígenas do Brasil (os Paiter Suruí, de Rondônia), também já nos colocava em relação com algo de nossas origens - a temática escolhida.

${ }^{4}$ Peça juvenil A moça de Bambuluá e o projeto de narração de histórias Círculo de giz, roda de gente, mundo de histórias. Informações sobre esses trabalhos podem ser obtidas em: <www.aivuteatro.com>. Acesso em: 10 jul. 2014.

"Consideramos dentro da experiência que vivíamos que a palavra "homens" diz respeito a todas as pessoas de uma comunidade ou de um contexto, independente do gênero. Devoramos da cultura Paiter Suruí aquilo que ressoava sentido para nós naquele momento: o iamá como o espaçotempo da política e, ao mesmo tempo, da intimidade e da praça pública. 
Trouxemos o iamá para os nossos ensaios com muito respeito à prática da sabedoria indígena e, com licença poética, transformamos esse elemento em uma ação que inspirasse o nosso trabalho criativo. Cada uma de nós, as atrizes, sentamos neste banco - o nosso iamá - para contar as nossas histórias pessoais, de vida. Iniciamos do princípio mesmo: histórias e álbuns de infância, fotos da família, da cidade do interior, dos bichos de estimação, narrativas de amor e sofrimento, momentos inesquecíveis de traumas e alegrias.

Sentar no banco era um encontro consigo mesma e, ao mesmo tempo, com o outro. Ao revelar a minha história, ia ao encontro de mim mesma. Como se, ao compartilhar minhas narrativas pessoais, na relação com o outro que me ouvia, fosse possível ter uma compreensão, um entendimento, do que cada história significava pra mim, de como cada história ressoava em mim, muito mais profundo do que pudesse imaginar se somente estivesse relembrando-as sozinha, em minha solitude.

Neste momento do compartilhar livre de nossas narrativas pessoais, também já investigávamos uma qualidade de presença e relação com o outro que nos interessa encarnar na cena teatral. A atriz sem nada mais (figurino, luz, maquiagem, contracena...) que a sua humanidade e a sua integridade, presentificando a sua força, a sua energia, a sua criatividade, a sua complexidade, os seus entrelaçamentos. Suportando permanecer neste lugar de transpasse, conexões significativas e exposição que é a cena. Fortalecendo a sua musculatura poéticaética, para a partir daí poder encarnar quantos outros personagens, seres, forças, desejar.

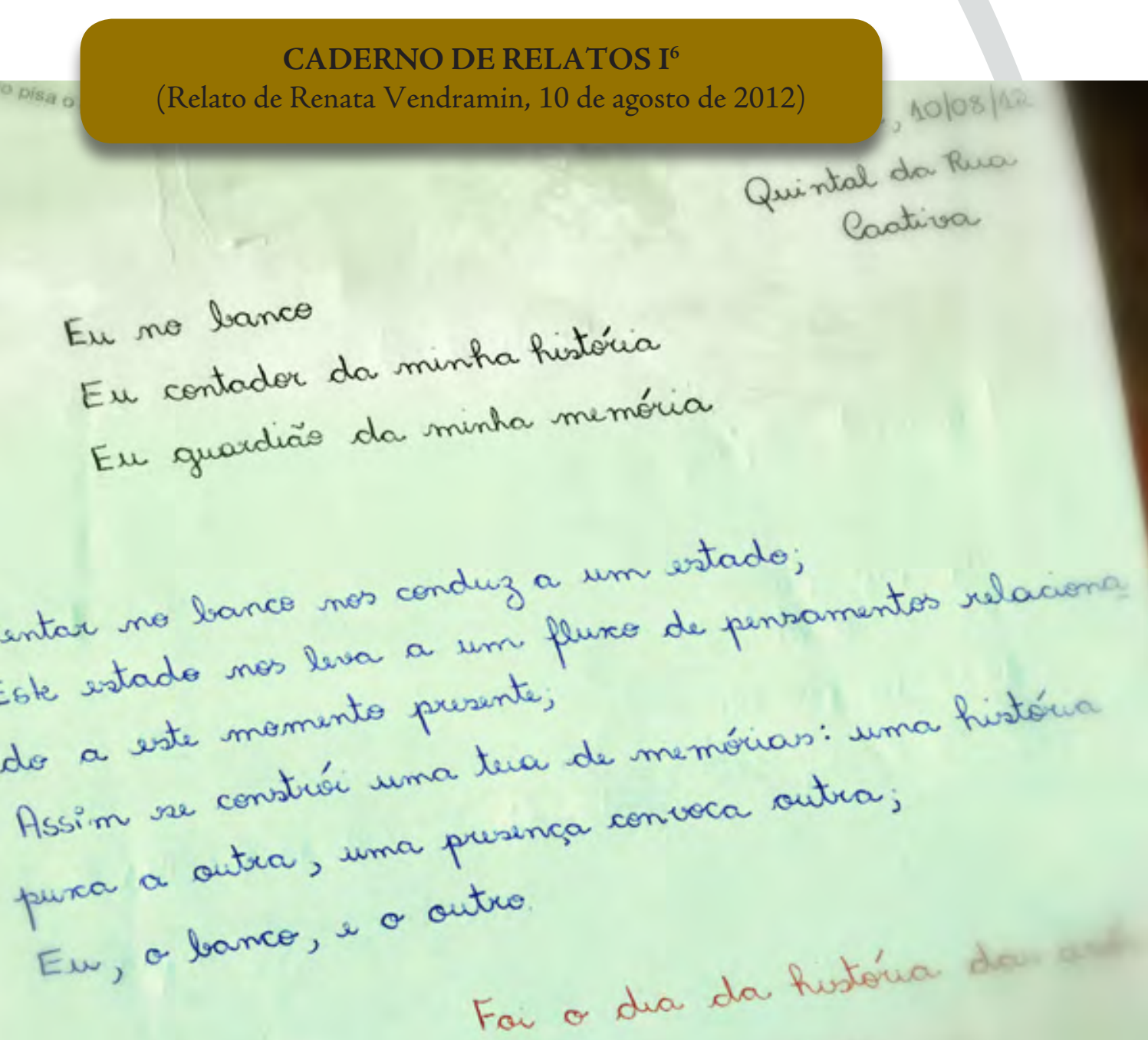

${ }^{6}$ Utilizamos desde o início do processo criativo Cadernos de Relatos coletivos do grupo. Ao final do ensaio, cada artistacriadora escolhia aleatoriamente um dos cadernos e relatava a experiência vivida no dia. Temos ao todo quatro Cadernos de Relatos coletivos do processo de cocriação de A Próxima História. Todos os relatos entrelaçados ao texto da dissertação foram fielmente reproduzidos, portanto podem aparecer alguns erros ortográficos que não foram corrigidos para que pudéssemos preservar as escritas originais. Entrelaçamento com o texto da página 30. 
Exercitamos o "sentar no pequeno banco". Neste momento inicial, privilegiamos o ato de contar as histórias usando a P A L A V R A. A força da palavra, a sua capacidade de encarnar sensações, movimento, música. Era a busca por uma experimentação mais pura da nossa relação com a palavra. A busca por ter uma compreensão mais afinada, por chegar mais próximo do lugar onde A P A L A V R A É o SER. Em que a linguagem está em perfeita sintonia com o que se é. A $A L M A-\mathrm{P}$ A L A V R A para a tradição oral guarani. ${ }^{7}$

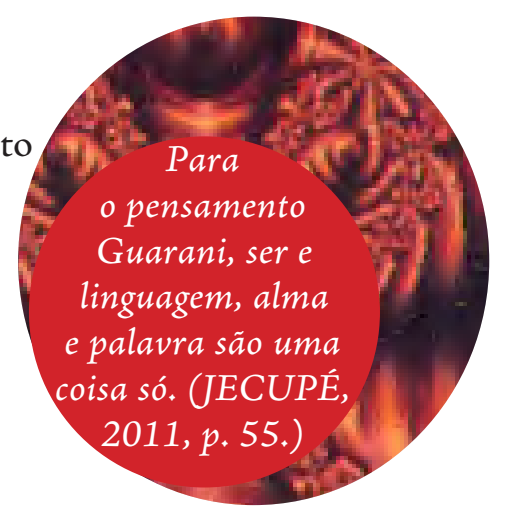

Palavra que já nos interessava desdobrar em sonoridade, em música, em movimento corporal, em gesto, em dança na cena, e para que isso aconteça é importante que exista uma relação fina com a palavra. Apesar de a palavra ser constituída de uma substância etérea, mais sutil (não podemos pegar as palavras nas mãos, como a oleira pode amassar o barro), a intenção era, sentada no banco, eu com minhas histórias, com minhas palavras, botar as mãos nestes sopros preenchidos de sentidos, lidar com eles, modelá-los em formas diversas. Exercitarmo-nos para tornarmo-nos mais íntimas das palavras, para sintonizar o nosso pensamento e ação de fala, de emissão da palavra.

\section{CADERNO DE RELATOS I}

(Relato de Janaína Silva, 03 de junho de 2012)
NARRATIVAS PESSOAIS

\section{DE CHUPETAS}

Eu sou a filla cafula de 3 irmíos. Suanio eu tinha 4 anos perd ra a minha mate para ir pra escom sem ninguém tara brincar en casa sozinha toda a Thou dó que nesta éfoca eu andava MinHA MAE GOSTOU DA UMA NA BOCA E OUTRA QUE EU

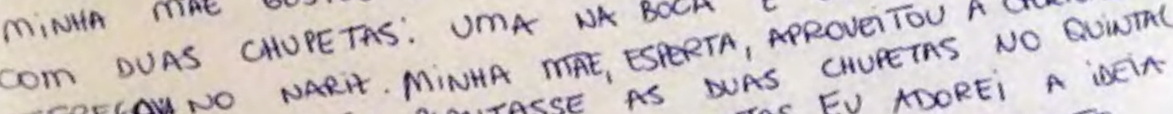

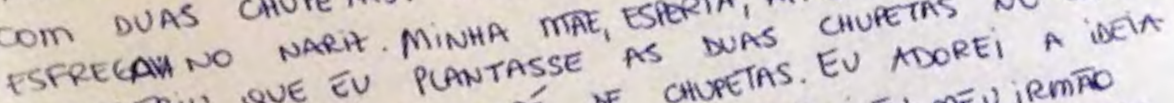
e sugeriu gue Evesse umpé de chupetas. Eú. Eu, mevirmáto

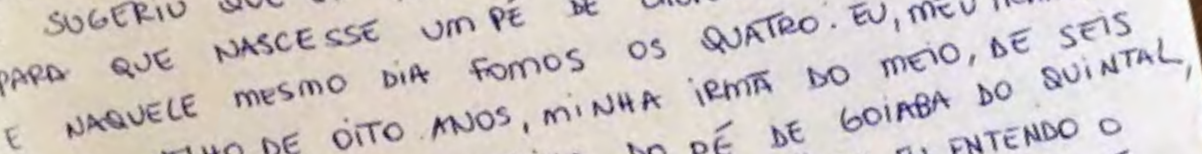
MAIS VEUHO, DE OITO ANOS, DEBXO DO PE DE GOIRO ENTENDO O E minHA MAE, PRA DEBMES DE CHUPETA. HOJE EU ENTENDES, QUE JÁ

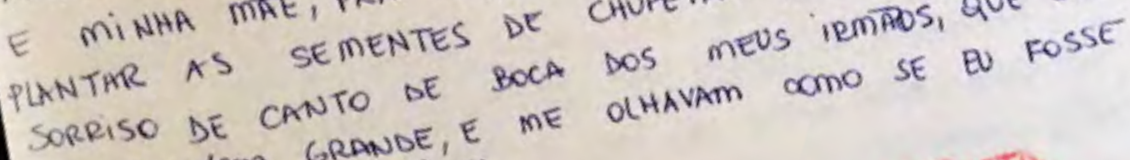

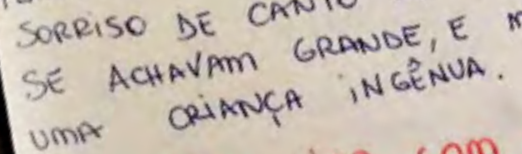

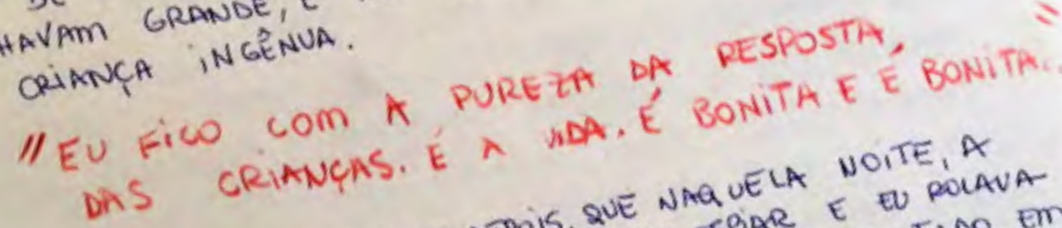

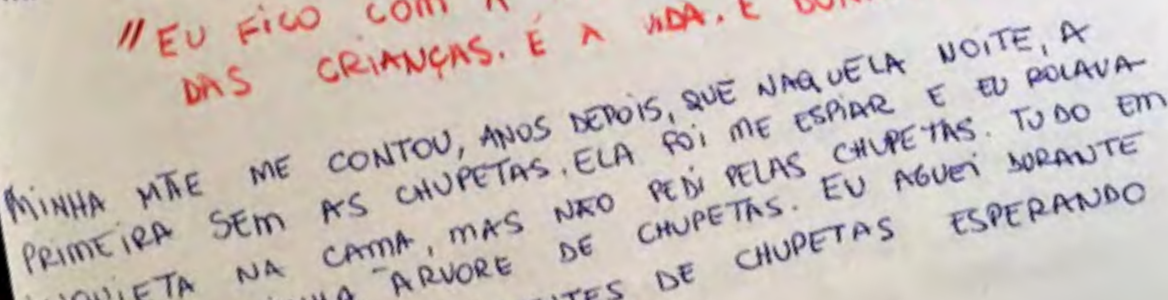
INQUIETA NA MINHA ARUORE DETES DE

UMA SEMANA AS DE ÁRVORE.

por um
Um dos livros devorados durante o nosso processo criativo foi Tupã Tenondé: a criação do universo, da terra e do Homem segundo a tradição oral Guarani, que, além de nos alimentar criativamente através das suas narrativas de origem, aproximounos também de outra tradição indígena, do povo Guarani paraguaio Jeguaka Tenondé. A intenção desse livro, organizado por Kaká Werá Jecupé, é compartilhar esses ensinamentos sagrados da tradição oral guarani com a civilização não-indígena $e$ "colaborar na formação de corações valorosos capazes de respeitar e valorizar a diversidade cultural num mundo em que, cada vez mais, alguns povos pretendem impor a outros sua maneira de ver e se relacionar com o mundo e a natureza." O pensamento guarani que nutre e dá forma às narrativas do livro está em sintonia e apresenta similaridades com o pensamento sistêmico que se relaciona com o mundo como uma teia interdependente. 
A Lua no Toce.

A primetra palavra que eu aprendi a factar foi lua. Eu era fascinada pela lua. Minha tia, comigo no colo, dizia: Olha a lua, Jana! E eu respondia: A uuua! A uuuuua, Jana! E eu chorara, chorava, chorava. Chorava sem motivo. Chorava tanto e ninguém sabia o porqué. Nao tinha o que me fizesse parar de chorar. Meu pai contava histórias pra ver se eU parava de chorar e nada. Eu esgoelava mais ainda. É fome? Ná! É SONO? NaO. Alguém fez alguma coisa pra ela? NAO! E EU ChORAVA! A minha AVó, VENDO O DESESPERO dO mev pai, trazia doces, pra ver se eu parava de chorar E... nada! Na frente da casa da minHa AVÓ tINHA UM TRONCO DE ÁRORE CORTADO, QUE SERVIA DE banco. NumA NOITE EU choraVA, choraVA, CHORAVA... MEU PAI. TEVE a IDEIA DE mE LEVAR pra sentar no Toco, pra ver a Lua. Eu parei de chorar, na hora! 


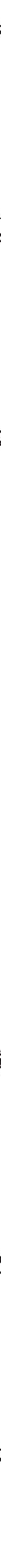


da vó...

Simultaneamente à prática de exercitar o iamá, investigamos narrativas, histórias, músicas, poemas, movimentos, que permitissem nos relacionar com nossas origens para além de nós, para além do além. Coisas que nos contaram, crescemos ouvindo, ouvimos há pouco, inventadas pelos poetas, pelos clássicos da literatura ou religiosos, que inventamos, que alimentaram e alimentam o nosso imaginário.

\section{Fomos BATURANOANOBm}

BATMNDO o espaçotempo de cocriação com todos esses materiais artísticos, referências, elementos devorados...

\section{Faixa 02: Vale do Jucá}

DVD 01 / Faixa 02

${ }^{8}$ SIBA. In: Fuloresta do

Samba. Recife (PE):

Estúdio do Poço / São

Paulo: Indio Music, 2002.

CD. 


\section{De quantas histórias é feita a nossa história?}

$$
\text { De quantasvozes? }
$$

Dequantos $, i, \ldots, \ldots$ ?

$$
\begin{aligned}
& \text { De quantos geston? } \\
& \text { De quantos che ir }
\end{aligned}
$$

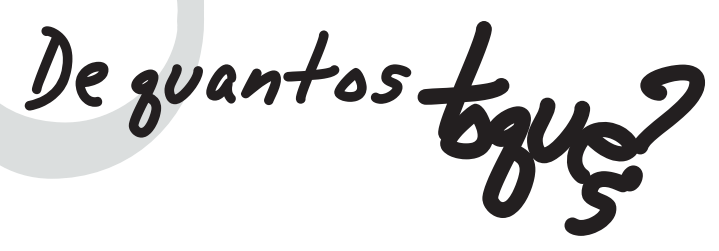

A busca pelas histórias era também uma busca pelas $v \mathrm{O} Z \mathrm{E} \mathrm{S}$ que as guardam, que as contam, que as transmitem, que as silenciam, que as inventam, que as modificam, que as distorcem, que as transformam, que as matam, que as transcendem... a voz da voz da voz da voz da voz da voz da voz da voz da voz da voz da voz da voz da 
da voz...

O mergulho primeiro nas nossas narrativas pessoais era uma busca também pela nossa VOZ de artistascriadoras, pela nossa VOZ POÉTICA. Inclusive para descobrir, em meio a essa grande e complexa temática O R I G E M, o que desejávamos dizer, sobre o que teríamos condições e maturidade para falar e, principalmente, como faríamos isso teatralmente.

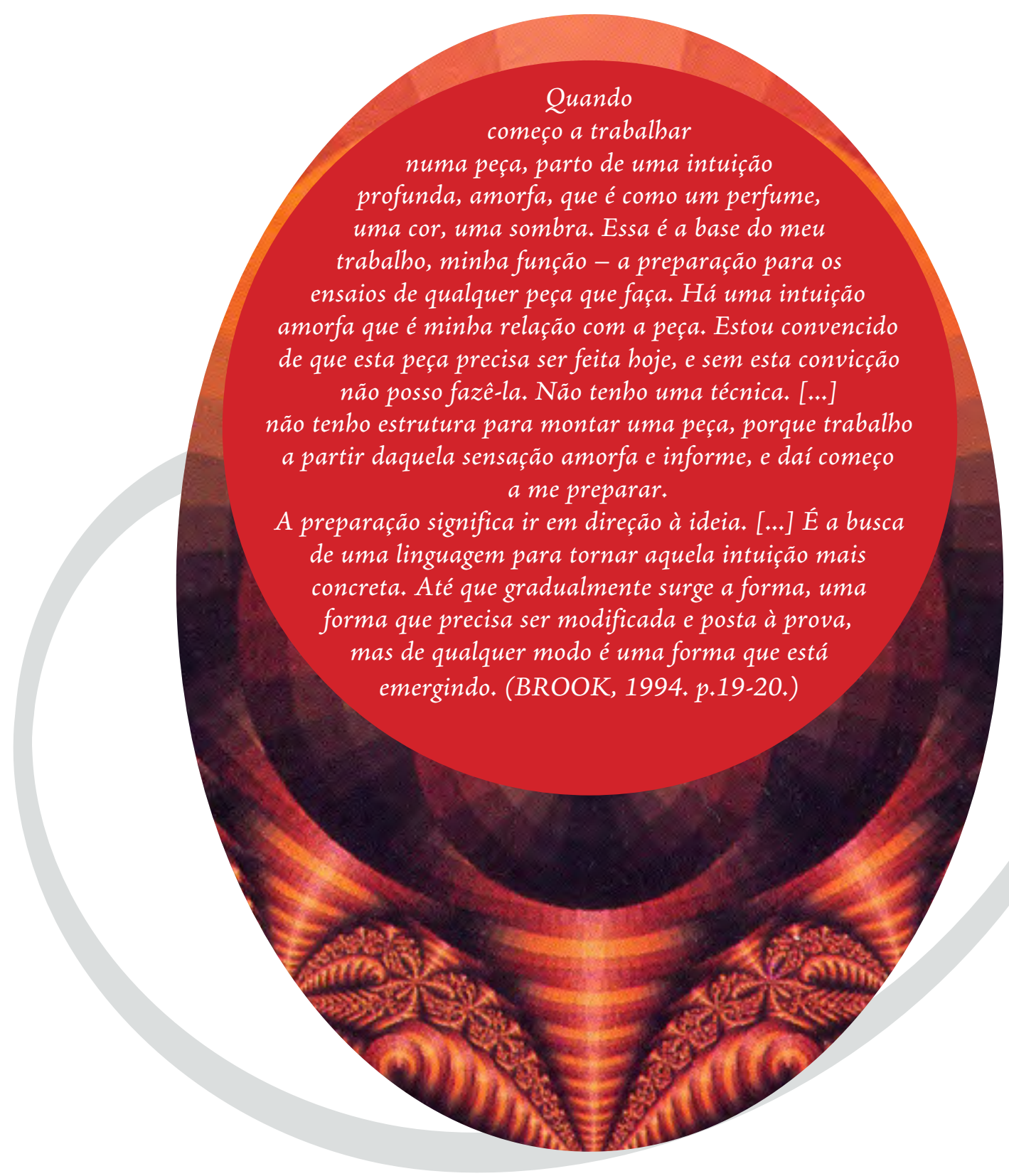




\section{PRIMLIKOS $P A^{S} S^{0} \mathrm{~s}$}

Desde o início do desafio da cocriação dessa peça, adotamos a prática de utilizarmos CADERNOS DE RELATOS COLETIVOS do processo criativo. Cadernos com folhas em branco, sem pauta, em que após cada ensaio paramos para contar alguma coisa sobre a experiência que vivemos no dia. Tudo era válido: narrativa, descrição, poesia, música, versos, desenhos, questionamentos, desabafos, intuiçóes, frustações, objetividade, subjetividade... era um espaço aberto, sem preconceitos, padrões e regras. Os cadernos funcionavam como o R G A I Z A D o r e S DA EXPERIÊNCIA, uma forma de dar concretude, materialidade a ideias, sensaçóes, emoçóes, pensamentos, intuições, reflexões, imaginações, transformações que vivenciáramos no intenso processo de ensaios. Algumas vezes, após escrever no caderno depois do ensaio, líamos o que havíamos escrito, e, ali nas palavras de cada uma, em que se repetiam coisas, revelavam-se as diferenças de pensamento, os pontos de convergência e divergência, as necessidades de cada uma de nós; eram suscitados diálogos, reflexões, perguntas que nos davam a direção que o processo pedia. Apontava-se o próximo passo que deveríamos dar. Vale ressaltar que a prática da escrita, a disciplina de realizar o exercício constantemente, era tão importante ou até mais do que o seu conteúdo, o que escrevíamos nos cadernos.

Anotar no caderno é uma prática muito antiga e corriqueira na vida de muitas artistas. Eu mesma tenho esse gosto e costume de escrever sobre as experiências que vivo desde sempre. No entanto, neste contexto de COCRIAÇÃ $\mathrm{O}$ em que vivemos no A I V U, sem a presença de uma única pessoa que ocupe a função de diretor, o caderno, o exercício da escrita logo em seguida ao ensaio, cada uma de nós em um dos cadernos, assentando a própria experiência e depois compartilhando na leitura, ganhou outra importância. O relato conjunto, ao mesmo tempo individual (cada uma em um caderno) e coletivo (depois compartilhado), realizado no calor da sala de ensaio, ainda vibrando tudo o que havíamos experimentado na prática, auxiliava muito nas escolhas de direção da investigação e também da peça. Às vezes os próprios relatos traziam indicações que nos norteavam, outras vezes um relato influenciava alguma escolha de direção de uma de nós.

Em um dos relatos feito no dia 20 de novembro de 2012, Janaína e eu iniciamos e terminamos o nosso texto particular, escrito individualmente, com as mesmas palavras:

\section{nasce $_{\mathrm{e}}$ Morr $_{\mathrm{r}, \mathrm{nasce}} \mathrm{mor}_{\mathrm{e}}$}


Solu|12

CADERNO DE RELATOS II

(Relato de Janaína Silva, 20 de novembro de 2012)

Nare e morre - naree es morre - warce e mane naxe e move - wase e move - warce e movre naxe e morre - marce e move - narce hoje Maria. Naree hoje a pulvo comom. Resperacaio no pulso de tambor como ferramenta para o alinhamento interno para o alintramento de duas presencas (co) viando a cena.

Penso em pequenas ćlulas de origem. Piquenos movimentos que sugerem o princépio de algo. O mincépio do mundo. Princé pios. Presupostos. Primiro som que gera a fala. Primeiro paro que trár a danca. Penso no ielencio que mecede - Tado. Penso no verdadeino desejo de contribuir com a escuta pimeiro. Depais a fola, alimhada. no toque do tambor. Siléncio

Exurácio de Cono GraffiA $\longrightarrow$ alinhamento das risiténcias do coppo. fair do confarto da danca de simpre. Pancar num pulso comum. "Eu botando meus "de simpe" pia dancar.

- narraturá compartelhada trás sinais, ainda náo minto nétider pa mim, do caminero que se apusenta para * trabaho. I tRÁNSITO entre uma descricáo que vira música que vira dama que vira gesto que retorna a ralava que cria múndos. Infinitas prosibilidades de dan vida as rabaures que moram numa listoria

Os rayatos da elariss e us tamancos da vó Maria. Os pús chatos da ińdea. Os pés que dexalsos, enreergam. Pé í raiz' né?

31 
Naxe e Movre, Nasce \& Morre, Nasce \& Movre... Brincar de Renaseer É o toque do tambor. Repetiça nöo existe. É Naximento. Cada toque traz um toque diferente, cada respiraç̃o s' única. A música como organismo vivo.

Exercícios de PULSO. Pubsar juntas para instaurar o pubso no encontro. Seja ol instrumente musical, can a voz, can a movimento, com a palavea. É do pubso comum, do som ouginal, da Fonte sonora, que partem todas as manifestaçeres.

Exercício do Tambor: Pubso do Coraçäa

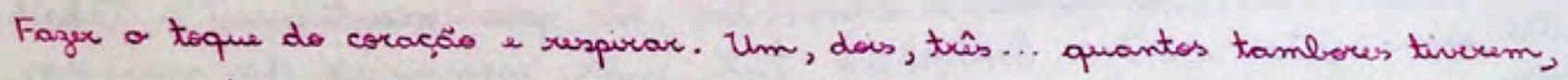
no unesmo toque, na mesma respiraçeo. Podemos sugerix regiörs do coxpor para respirar.

* Movimentos de Origam.

COREOERAFIA $\rightarrow$ COROERAFIA :

A grafia do Coro no ispace. T Coro materializado em movimento corporal. Qs movementos realizpdos en conjunto, iguain, evidenciando que estamos no mesmo pubso. le importância desta prática para a incorporacioso do pubse e entendimento para que a criaçäo nasça do pubso comum e irradie um inimeras el inimaginávies manifestaçâs.

¿O que e' essencial ser praticado?

¿ q que e' essencial ser compartilhado sta mossa experiência criativa?

C Navraça da História: colocar-se, abrix a boca e começar. As práticas e o punsamento que ancaram e protegem o trabalho nos permite recompecer fagendor, o que precisor e pode ser fito.

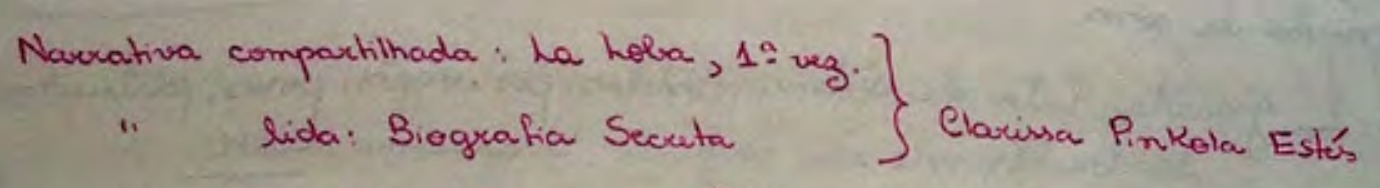

Narrativas sober Pés! P2's raic né? 
Neste dia como que despertamos outras camadas, outros níveis de entendimento do que é o P u L s O com M M do trabalho, a BaTiDa Do CoRaÇãO dA pEçA, de como abrir a escuta para cocriar um projeto comum que está sendo gestado para além de nós individualmente, no encontro, na relação com o outro, com a temática, com os elementos que colocamos em relação no espaçotempo de cocriação. Neste dia, como podemos perceber nos relatos, praticamos um exercício usando o toque do tambor em que trabalhamos com o pulso comum. ${ }^{9}$

Quando a vida começa a tecer em nós um projeto comum, a principal ação é escutar.

Não é um escutar passivo, dissociado lcomo se existisse algo pronto

e fosse só uma questão de baixar esse conteúdo do campo da consciência humana). Parece que a coisa está se formando na medida em que eu a escuto.

Trata-se de ir construindo esse órgão de ver/escutar o mundo enquanto possibilidade - sentir isso, ir com vivendo com as coisas na essência e potencialidade delas, "adivinhando" o movimento que elas querem fazer. $E$ um escutar dinâmico, pois requer mover-se com a

coisa, prestando atenção se está havendo agarramento por

identificação com uma dada expressão que ela está tomando.

O próprio escutar - e não tanto o que se escuta - vai alinhando forças dentro e fora. Escutar catalisa, principalmente se não colocamos a estática do interesse próprio ou de receios que distorcem a sinalização.

Com que qualidade interna eu perscruto algo que está se tecendo?

Eu me disponibilizo para tudo que estiver chegando - ou só para o que eu torço que aconteça?

O meu escutar é um trabalho junto com as ocorrências ou eu fico lamentando situações que são colocadas ou tiradas?

Com que sentimento eu me coloco diante das forças vivas que estão desaguando em nós?

\section{Eu deixo isso atuar?}

\section{Eu sinto os pontos de resistência?}

Todo o meu ser - as minhas células, nervos, poros, tudo recebe essa água com alegria? ${ }^{10}$

${ }^{9}$ Entrelaçamento com o texto da página 56.

${ }^{10}$ Encontrei com esse texto pela primeira vez em uma postagem do facebook feita por uma amiga, Nathalia Leter, em 06 de dezembro de 2012. 
Aos poucos, começaram a chegar, por necessidade do processo, além dos materiais artísticos (músicas, poemas, versos, textos narrativos, imagens, qualidades de movimentos corporais...), textos escritos por autores diversos que inspiravam e norteavam a nossa prática teatral. Em sintonia com o que já vivenciávamos no nosso espaçotempo de cocriação, chegaram Eleonora Fabião, Fritjof Capra e Peter Brook. Os textos e seus autores foram trazidos por nós, por ${ }^{\mathbb{I N T U I C A} A O}$, AFINIDADE, SINCROnicidade. Eram também diferentes vozes chegando para o trabalho, que traziam reflexão, profundidade e apoio à investigação $e$ à cocriação. Conectamo-nos a Capra e Brook, quando decidi fazer o projeto do mestrado sobre a investigação que já estava em curso. Decisão que tomei justamente pela necessidade de ter mais consciência sobre a prática que já fazíamos, e também pela necessidade de dialogar com outras vozespensamentos comuns ou divergentes. $\mathrm{O}$ mestrado foi uma oportunidade criada e um desafio aceito para que acontecesse um amadurecimento como artistacriadora e como grupo.

Outras vOZE S chegaram ao
E $\mathrm{S}$ A Ç OTEMPO de COCRIAÇÃO!
Como?

Primeiro nos relacionamos com elas individualmente, cada uma na disciplina do seu estudo particular. Lemos alguns textos e começamos a trazer essas vozes e os pensamentos que elas encarnam para o espaçotempo de cocriação. Chegamos a ler textos inteiros juntas no ensaio e depois começamos a experimentar lançar trechos, parágrafos, frases, em meio a nossa prática física, deixando que as palavras alimentassem criativamente o nosso corpo em movimento. Deixando que o corpo descobrisse outras formas de entrar em contato com as vozespensamentos trazidas para além de uma recepção racional.

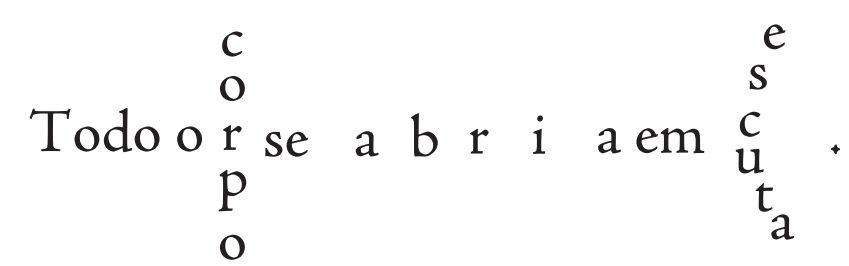

A pele escutava, o braço escutava, a tíbia escutava, o sexo escutava, o fígado escutava, a sola dos pés escutava, a unha do dedo mindinho escutava. As palavras alimentavam não só o(s) nosso(s) corpo(s), mas também o nosso espaçotempo de cocriação.

\section{SATURAVAMONOS.}

Ensaiávamos em círculo (uma arena) e as vozespensamentos lançadas ali ficavam presentes, saturando o espaçotempo com sentidos, reflexões, possibilidades de vir a ser. Como se todo aquele material estivesse ali disponível para a qualquer momento nos auxiliar aguçando a nossa percepção e imaginação - a encarnar algum movimento, música, gesto, ação, dança, poesia, canto. Era um conhecimento que estava sendo disponibilizado para ser conhecido, acessado, (re)descoberto e (re)inventado na prática teatral. 
Dois exercícios bastante importantes na trajetória do processo criativo foram cocriados a partir da inspiração de nossas leituras.

Estes dois parágrafos de Peter Brook concentraram e modelaram a energia para a criação do exercício de improvisação que chamamos de E S P A Ç O DO CírCULO. Usamos esse exercício para experimentar textos que cocriamos, o estado do trânsito entre a palavra, a música, a dança, a sonoridade, e também para nos relacionar com o círculo, com a qualidade de relação que ele nos convida a estabelecer com o público. Algumas ações, alguns movimentos, alguns gestos que foram descobertos nas improvisações foram retomados para a cocriação de cenas (que não necessariamente ficaram na peça, mas que serviram para darmos passos na nossa trajetória). O espaço do tapete de Brook transformou-se no nosso espaço do círculo.

Riscamos um círculo com giz de lousa no chão, e esse passou a ser o espaço em que começamos a trabalhar com alguns textos escolhidos, utilizando a improvisação. Mais tarde chegou a lona que demarcava o espaço (que faz parte da cenografia da peça) e dispensamos o giz.

Da mesma maneira, no mesmo fluxo criativo, pois as inspirações e a proposição dos dois exercícios aconteceram sincronicamente (um num dia de ensaio, e o outro no ensaio seguinte), nasceu o JO ${ }^{G} \mathrm{O}$ DO TRÂNSITO, inspirado pelo texto de Eleonora Fabião.

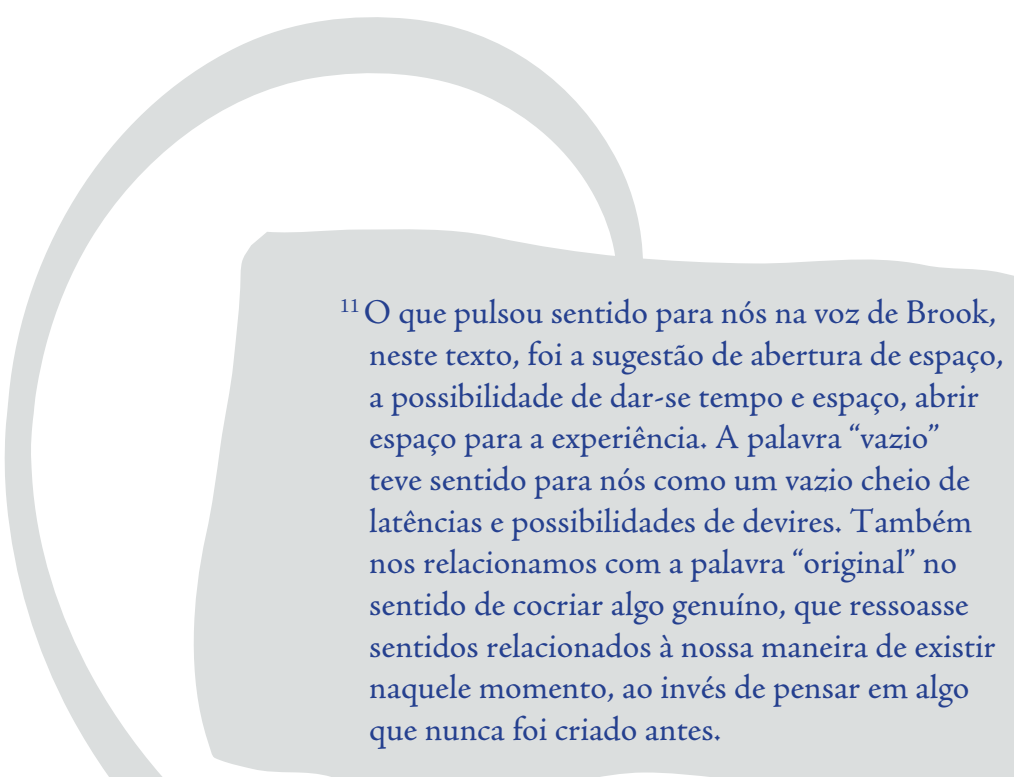




\section{Outro \\ entrelaçamento}

que o corpo cênico investiga é a

trama memória-imaginação-atualidade

- o fato de que circulamos e entrelaçamos

ininterruptamente referências mnemônicas, imaginárias e perceptivas. O que o corpo cênico explora, para além da dicotomia ingênua que contrapõe ficção e realidade, é a indissociabilidade entre essas três forças.

Como o corpo cênico experimenta, imaginar implica memória,

rememorar implica imaginação, e ambos os movimentos se realizam na atualidade fenomenológica do fato cênico. Além disso, ator é criatura capaz de realizar insólitas operações psicofísicas como, por exemplo, transformar memória em atualidade, imaginação em atualidade, memória em imaginação, imaginação em memória, atualidade em imaginação, atualidade em memória. É sua alta vibratilidade e sua fluidez que permitem essas operações psicofísicas. É sua inteligência psicofísica que abre dimensóes para além da dicotomia ficção $x$ realidade. (FABIÃO, 2010,

p. 323.)

$0403 / 13$

Em casa, olhando para a históra que ercrevemo até aqui-os nones, os esbours,

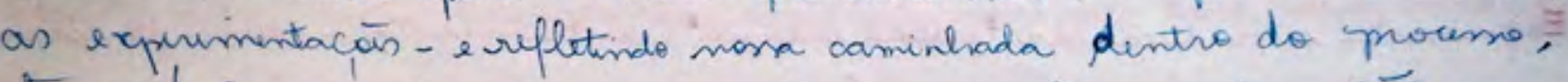
travei! Convo pá aconterew en untron momentos, paralisie. Vém questiona mentos de toda ordem. sobutude cons quanto a idéra de levarmos Spara a una nonas erapirinncias pessoas. Es que fazer eam ino? Como transformar una memoria penval em dramaturgia capary de dan conta do que quermos falar? Coma vau das noisas puŕmias narrativas e integrar a todos ne memo ponto de dircunäs? Qllo prana o que já experimentei até aqui e

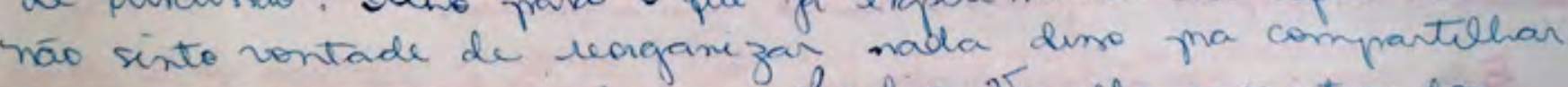
com ss parcuros que chegam. Paralise. Vaxculhe es regutios dos primeiros encontros do provena e re-encontro com "corpo cếvico ESTADDO CÉNico da Eleonova Falirä. Proponho um ExPERIMENTO EONVERSA com o material. A intureño diz que é dá que pode sungir a que desijo propos aos parcieros que chegam. 
Neste momento, em que o processo criativo necessitava de alguma ação que nos permitisse dar um passo além, como relata Janaína, um momento de paralisação, de impasse, o encontro com as vozespensamentos que já estavam conosco trouxe a luz que necessitávamos. Um momento do processo em que o trânsito e a integração entre a teoria e a prática aconteceram em FLUXO CRIATIVO.

O JOGO DO TRÂNSTIO sentadas, cada uma de nós em um pequeno banco (o iamá, que se desdobrou em dois durante o sistemaprocesso), de frente uma pra outra, começamos a experimentar o trânsito entre narrativa pessoal (memória), narrativa fabulada (imaginação), alguma fala sobre o presente (atualidade) e algum(a) movimentogestosonoridademúsica. Uma das atrizes começava a contar uma memória pessoal; em algum momento, a atriz que ouvia, "pegava" uma palavra da narrativa que ouvia e iniciava uma história fabulada, até que em algum momento a atriz que ouvia, "pegava" uma palavra da narrativa que ouvia e iniciava uma fala sobre a atualidade (qualquer assunto), até que em algum momento a atriz que ouvia era suscitada a realizar algum(a) movimentogestosonoridademúsica a partir de alguma palavra que ouvia e o realizava. A atriz que ouviavia, "pegava" este movimento e retomava a narrativa da memória pessoal do ponto onde havia parado, até que a atriz que ouvia, "pegava" alguma palavra da história que ouvia e retomava a narrativa fabulada de onde havia parado, e assim sucessivamente, em fluxo, em trânsito, em improviso.

\section{CADERNO DE RELATOS II}

(Relato de Janaína Silva, 05 de março de 2013)

- Proporha o jogo rom as ideias de Eluonara Fálräo. Plomeamos TRAMA MEMÓRIA-IMAGINACAO-ATUALIOHEE comecaremos por una "lalina" simples ique prosra. permitur corcularmos e entrelacarmos ininterruptamente referencias MNEMÓNIGAS, IMAGINKRIAS \& PERCEP TIVAS. A indissociabilibane entre essas tres forcas. $r$

IMAGINAR implica MEmórit-rememonar IMAGINACPOO

\section{1Т}

- TRansformar

memória

IMAGINACATO

MEMória

IMAOINACAO

ATUALIDALE em

ATUALIDADE em

em
atualidADE

em ATUALIDADE

IMAGINARAO

METMÓRIA.

imaginacta

MEMória. 


\section{CADERNO DE RELATOS II}

(Relato de Renata Vendramin, 05 e 06 de março de 2013)

Tas jogos se apresentam. Concrutizam - se no ispaço inspirados mas rdeias de Peter Brook e Eleonora Falião.

- Oespace do Pículo

- As 4 instáncias do Tempo (mamóvia, Fabulagão, Atudidade, Movimente)

Organizar o espaço, tragando um cúrculo no chão, aE definindo as balizas que

DENTRO: a vida í condensada, potencializada, cria terna realidade outra; um espaço em que nada s' gratui FORA: a vida acontea como a gente quiser, em osalacpers de ritmos despreacupadars;

Mudau a rulaçäo com o nosse ispace-coupo, com a espage-rala de ensaio, com o supace-coupo-do-autro.

Estamos mais livees, nos celocando mais em xisce, como se a gente souberse que as entrar no cúculo é tudo ou nada, it Hom temos o alento que a qualquer momento pedemos sair da burea de risco.

(1) truino do trânsito: truinar o próprio corpo para transitar entre as $\neq s$ instancias i treinar $\theta$ 'olhar ip| o trânsito' vendo o outro realizar. Co ver a experiência do outro um cena, em trânsito, amadurege e aperfeiç,o a minha experiência.

Sana lu trechos do textos da Eleonora Fabião: Estado lênico, loypo lênico. lis palavias ecoadas no espaçe, lorrifadas na me mória, ajudam a ancorar a experiência. Ses palavias a oportunidade de ganhar corpo. Vamos tecendo a nossa rede de compeci. mento que transita entre prática e teocia, em que nenhuma é mais importante que a cutra

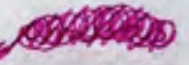

les flautas dialogaram pela 1a vez.

C. Mais welha au otempo: Main? m 


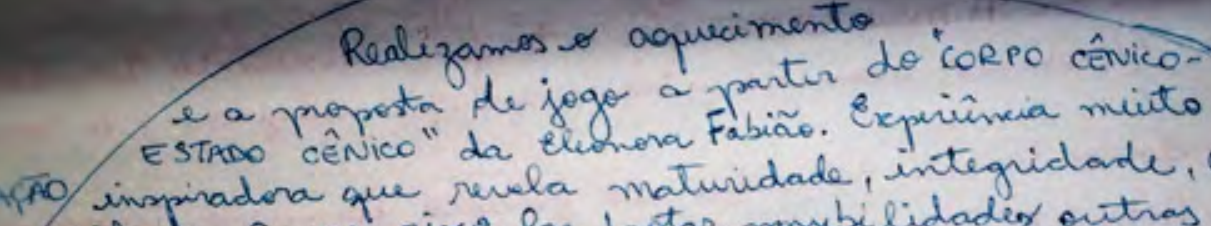
cidade. Sugeré rixes, faz brotar possubilidades outras de gesto, tento, açäo.

- As duas flautas tocando funto - a movinento do son como elemento harmonizato do corpo.

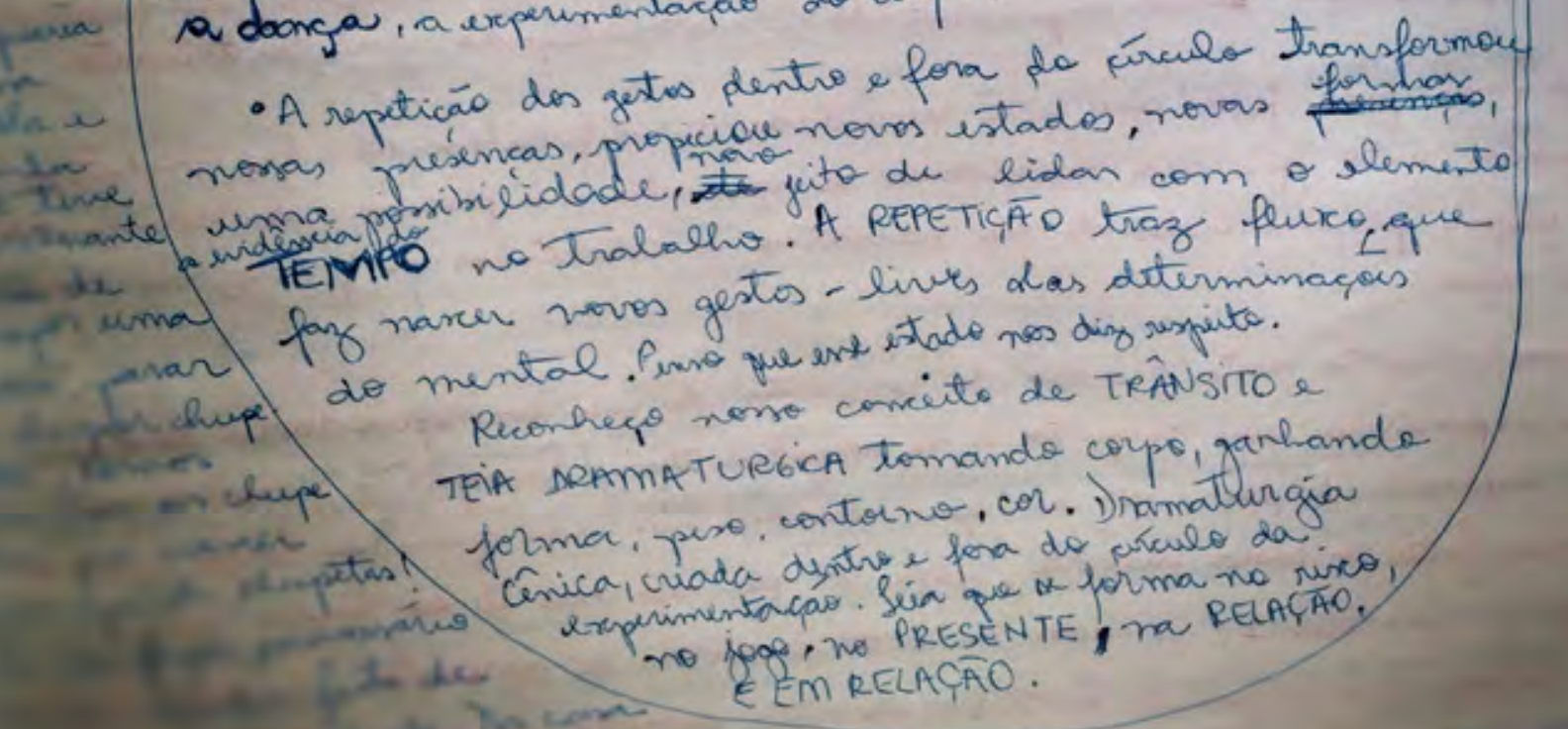

Mais do que descrever os exercícios cocriados durante o processo criativo para que eles sejam compreendidos e reproduzidos, a intenção é compartilhar a maneira como organizamos o processo criativo de A Próxima História, e como essa organização foi dando-se a partir das relações que constituem esse SistemaProcessO e dos encontros com referenciais teóricos, materiais artísticos, elementos que foram buscados e devorados conforme o processo sentiu necessidade, em fluxo e ritmo criativos.

\section{COMPreEndemos o processo CONFOrme o viVENCIAMOS.}

A vozpensamento de Fritjof Capra foi integrada ao sistemaprocesso por estar em sintonia com a prática que já realizávamos e nos auxiliar a aprofundar e redimensionar esta prática na relação, na fricção, com as suas ideias. Tanto Janaína quanto eu já nos relacionávamos com os livros e pensamentos do autor para além do trabalho com o AIVU, por interesses particulares. Dessa maneira, já estávamos alimentando nosso imaginário com o pensamento ecológico ou sistêmico. Sendo assim, a conexão com a vozpensamento de Capra pareceu-me em determinado momento da trajetória da pesquisa bastante coerente e orgânica, acontecendo em fluxo criativo.

Antes de começarmos a modelar, a partir da experiência prática, o conceito deTEIA DRAMATÚR GICA, suávamos a ideia da AtriZ eM TRÂNSTIO, que também se relaciona com o pensamento sistêmico. A atrizcriadora que transita por diferentes linguagens na cena, que articula a palavra, a música e a dança na tessitura do seu discurso cênico, da sua poética, cocriando sentidos e semsentidos através da relação dessas linguagens, e, assim, tecendo uma teia dramatúrgica. A teia dramatúrgica surge como resultado do trabalho dessa atriz que tece em trânsito. Que lança mão de diferentes linguagens para entrelaçar e expandir sentidos, criar camadas de significações, para dar conta através da formaconteúdo do tema que aborda. 
Já utilizávamos teia dramatúrgica para nomear a dramaturgia cênica que cocriávamos, antes da escolha de Capra ser uma das vozes trazidas para se relacionar com a pesquisa. Com a decisão de trazê-lo para inspirar a nossa investigação, integramos a ação que já fazíamos com o pensamento do autor, e ambos estavam em perfeita harmonia. De fato, todas as vozespensamentos que se relacionaram com essa pesquisaexperiência, sejam artísticas ou teóricas, estão em sintonia com o pensamento sistêmico, no entanto, Capra dedica sua vida a escrever livros e articular projetos de diferentes naturezas que aprofundem a reflexão sobre o pensamento ecológico e gestem ações que encarnem essa maneira de existir no mundo. Por este motivo, o contato com sua obra foi bastante importante.

A consciência ecológica ou sistêmica, nesta pesquisa consideradas palavras sinônimas, (que reconhece e valoriza a indissociabilidade do conhecimento racional e da sabedoria intuitiva), convida-nos a olhar para o mundo, relacionarmo-nos com ele, percebê-lo como uma rede, como um organismo, cuja estrutura é criada em função da inter-relação e interdependência de todos os fenômenos que o constituem. Essa visão de mundo transcende (sem negar a importância) o paradigma newtoniano-cartesiano, que fundou a organização do seu pensamento na metáfora de que D DUND IIE UMA MÁ CUNA, constituído de peças separadas, blocos de construção, que se juntam para formar o todo. A consciência sistêmica é uma possibilidade de ser, de agir, de sentir, de pensar, de amar, de criar, de viver, de imaginar o mundo que privilegia as relações (entre seres humanos, organismos, sistemas), que nos convida a nos relacionar com o mundo de forma integrada e pacífica.

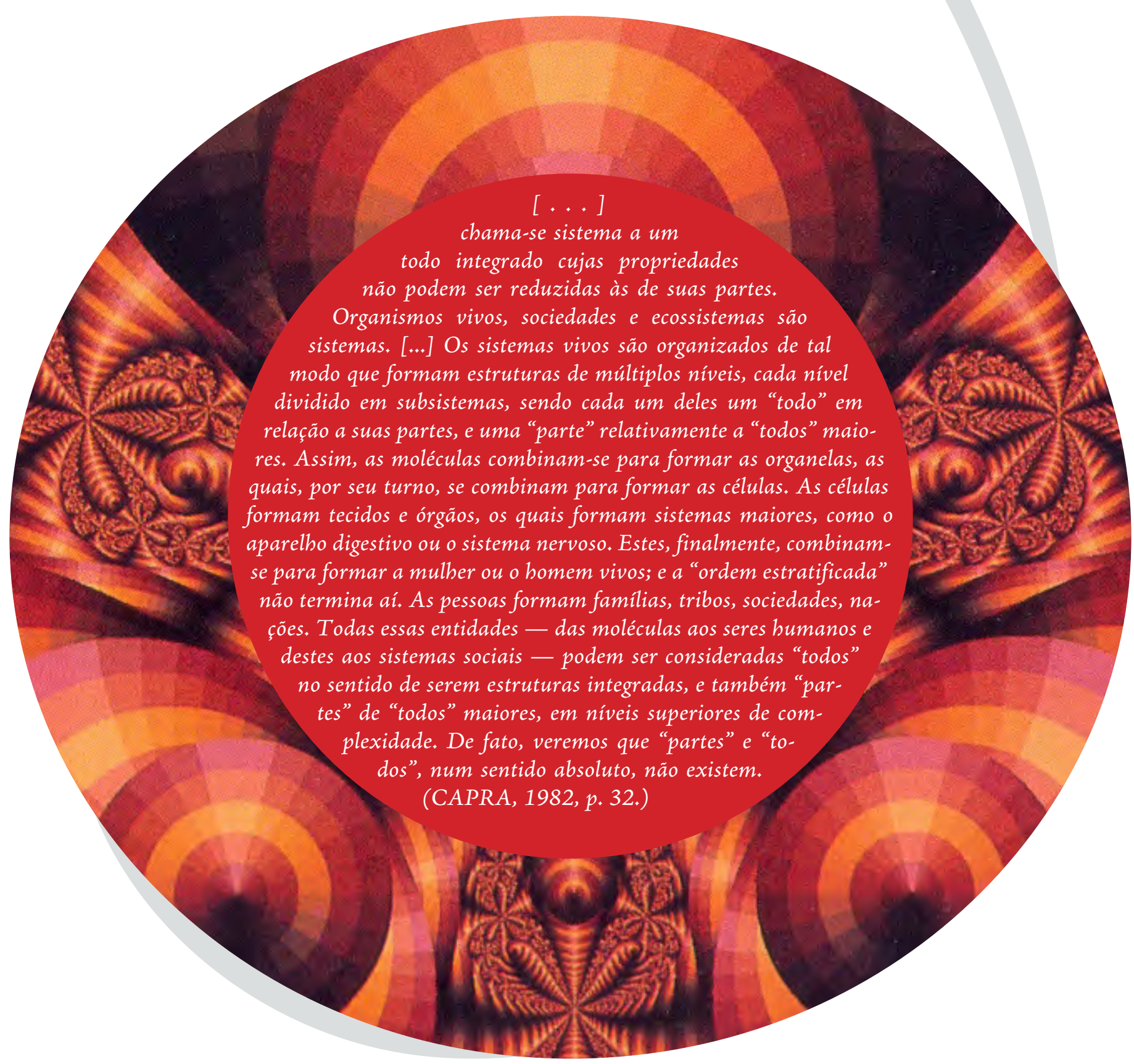


CADERNO DE RELATOS II
de Renata Vendramin, 26 de junho de 2013) gestada)

'Quando a vida começa a tecer em nós um projeto comum, a principal açäo é escutar.

Começamos a nos relacionar, a criar enperiencia com os liveros, pensamentos, a poética de Fritigg lapra. Friciamos pelo Ponto de Mutuação, cada uma fala de um capítulo \& vamos compreendendo individualmente e na relação os sentidos e as aberturas de sentidos que a pensamento do lapea traz, fagendo ponter, deixando ressioar pensamento filoséfico na prática da arte, que éconfigura ç, na carne.

'Com que qualidade interna en perseruto algo que esta se tecendo?'

A Terra

¿Que metáforas comporem o meu imaginário?

¿Se mudar a metáfora, mudo o padrão?

Puatrón: passibilidade de Ordenasão.

41 
Sentimos necessidade de mergulhar mais a fundo no pensamento de Capra, que é filosófico, e para isso escolhemos um de seus livros para estudá-lo juntas, Janaína e eu. O Ponto de Mutação foi a escolha, livro em que fala sobre a visão sistêmica de mundo em contraponto à visão mecanicista. Dividimos os capítulos do livro entre nós a fim de que construíssemos uma síntese e uma fala sobre cada um deles, como forma de suscitar, incitar, iniciar um diálogo sobre as ideias e sobre de que maneira poderíamos trazer algumas delas para a cena teatral, em formaconteúdo.

Iniciamos essa prática com o livro na metade de 2013 e fomos concluí-la no início de 2014, já com a presença do músico Alencar Martins Neto e do ator Gabriel Stippe, que começaram a integrar o sistemaprocesso no segundo semestre de 2013. Foi um exercício muito inspirador, produtivo e desafiador, pois é bastante difícil inserir - e fazer perdurar por um tempo - uma prática mais teórica como essa, durante o processo de criação de uma peça teatral, tendo todas as artistascriadoras comprometidas com a tarefa e realizando-a até concluí-la. Normalmente, delega-se a função para a pessoa que conduz o processo; no entanto, dentro do trabalho de cocrIAÇÃO que realizávamos, só fazia sentido se todas mergulhassem fundo juntas.

As ideias de Capra alimentaram textos, imagens, movimentos, músicas cocriados por nós. Muito do que fazíamos na prática ganhou E C O nas palavras de Capra. A prática e a reflexão sobre ela ganhou complexidade e profundidade à medida que nos embebíamos com a leitura do autor (principalmente Janaína e eu, que nos relacionamos por mais tempo com a vozpensamento do autor), com a maneira como ele articula o seu pensamento, cria imagens com as palavras. Capra não só fala e escreve sobre o pensamento sistêmico, como também experimenta uma forma sistêmica de articular o seu discurso, de organizar a escrita dos seus livros. E isto servia de referência e inspiração para a organização da dramaturgia cênica da peça: a nossa TEIADRAMATÚRGICA.

$\mathrm{Na}$ prática de respirar e suar as ideias de Capra, começaram a se delinear algumas perguntasdesafio (que foram e continuam sendo reformuladas sempre que acharmos coerente, harmônico, orgânico, sempre que o sistemaprocesso pedir):

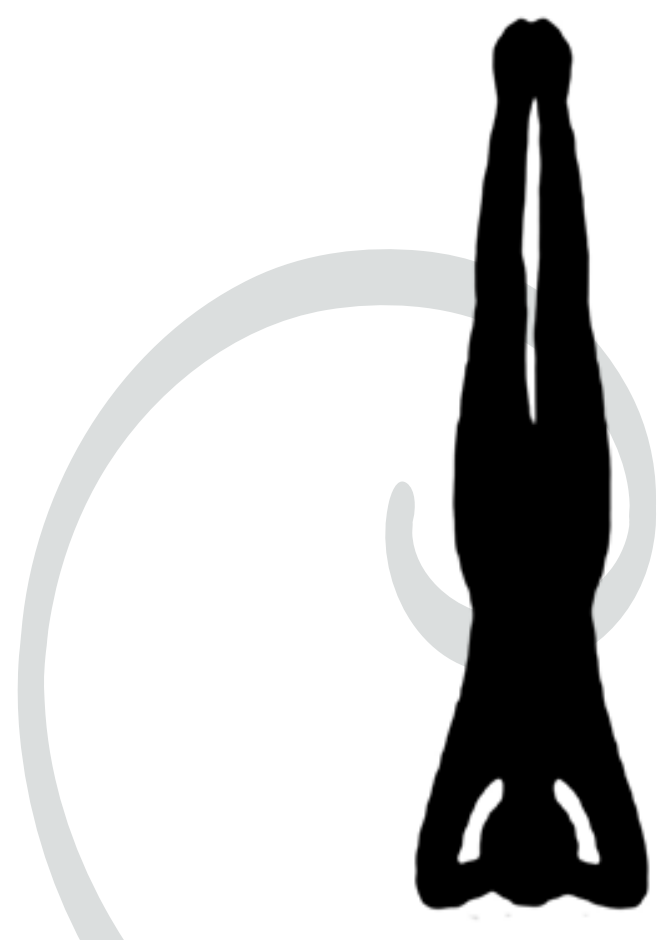

$\mathrm{Na}$ relação com o corpo, as atrizes

(artistas, nós) percebem o corpo de maneira

sistêmica? O que muda quando temos

consciência e começamos a perceber o

funcionamento sistêmico do nosso corpo?

Na criação da cena ou na atuação em cena,

como as atrizes (artistas, nós)

costumam agir: de maneira fragmentária

ou sistêmica?

O que muda no processo criativo e na

qualidade da criação quando ENCARNAMOS o

pensamento sistêmico?

$\mathrm{Na}$ verdade estas perguntas já estavam sendo feitas de alguma maneira desde antes da escolha de Capra, desde antes do mestrado, de maneira intuitiva, quando escolhemos na cocriação da primeira peça do A I V U trabalhar com uma fusão de linguagens para a criação da cena, quando experimentamos exercícios para a atriz que lhe permitisse desenvolver uma habilidade para transitar pelas linguagens, criar material cênico usando recursos de diferentes linguagens. 


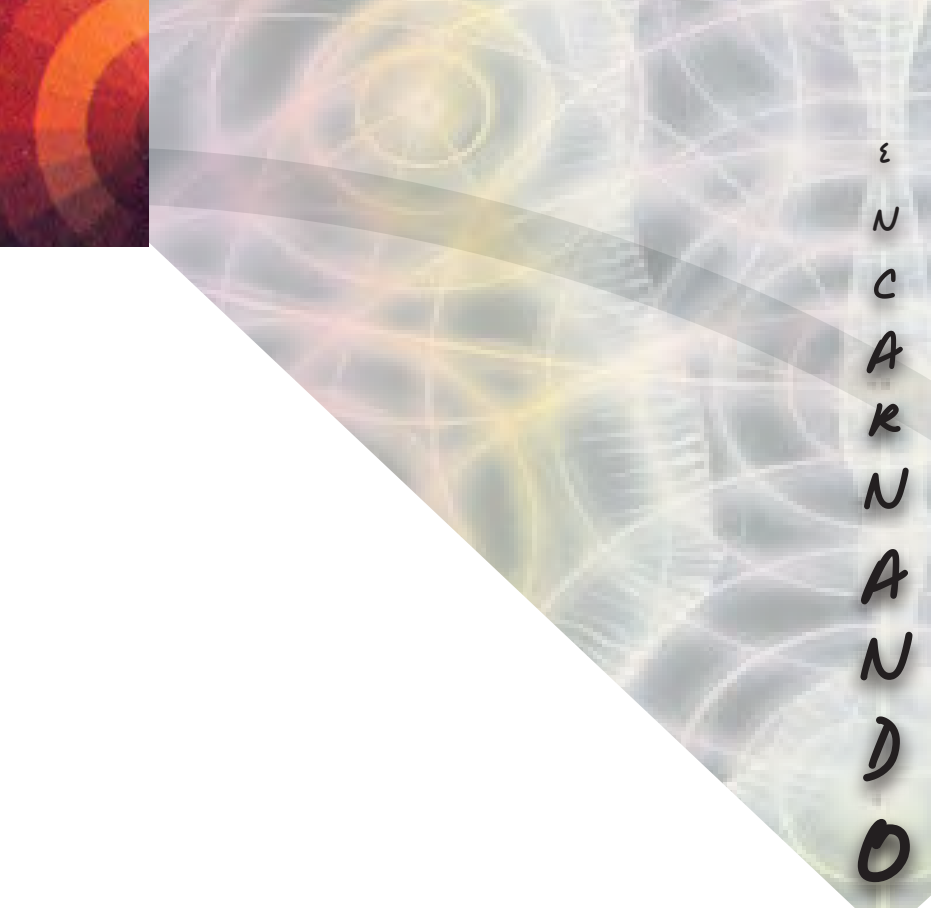

Faixa 03: Corpo ${ }^{12}$

DVD 01 / Faixa 03

\section{CADERNO DE RELATOS I}

(Relato de Renata Vendramin, sem data/2012)

\section{O corpo fala com o corpo}

- corpe í uma rede. Repusentagäe micue de macrecerme. Cilutas em comunucacăb, im comexäs. Canais de inergia que se cuizam. Mapa Ridregráfice. Espaces vagies. Espacers Entre. Lugar da Experîncia.

Entidade. Pulsante, aciemadera

- matriz receptora das manifes taçess. Wetenador, condutor, a própria expexiencia.

Citraves de coxpo (dos corpos) me rulacieno com o mundo (os mindes). Eu sxisto Coxpos! lus relaçars acontecem entre Corpes!

Coupe fnstrumento, Coupe Antena,

erpe Cenective, Memerana viscátil

\section{E É UM dizer QUE Dá EOSTO}

$\checkmark$ corpe vibra em estado.

\section{ESPELHO D'ALMA ANCESTRAL corPo cELESTE MIRAEEM} BRILHANTE ESTRELA DA TERra E dO CÉu

e forma que mue corpo tern revela como ustou, dó indicios de quem en sou.

C. forma estitica que dou ao mun corpe establece comexöes específicas. 10 corpo antena. Sintonizado a diferenters vibraçörs. 


\section{- Teatro acontece entre corpos. na relação entre os corpos.}

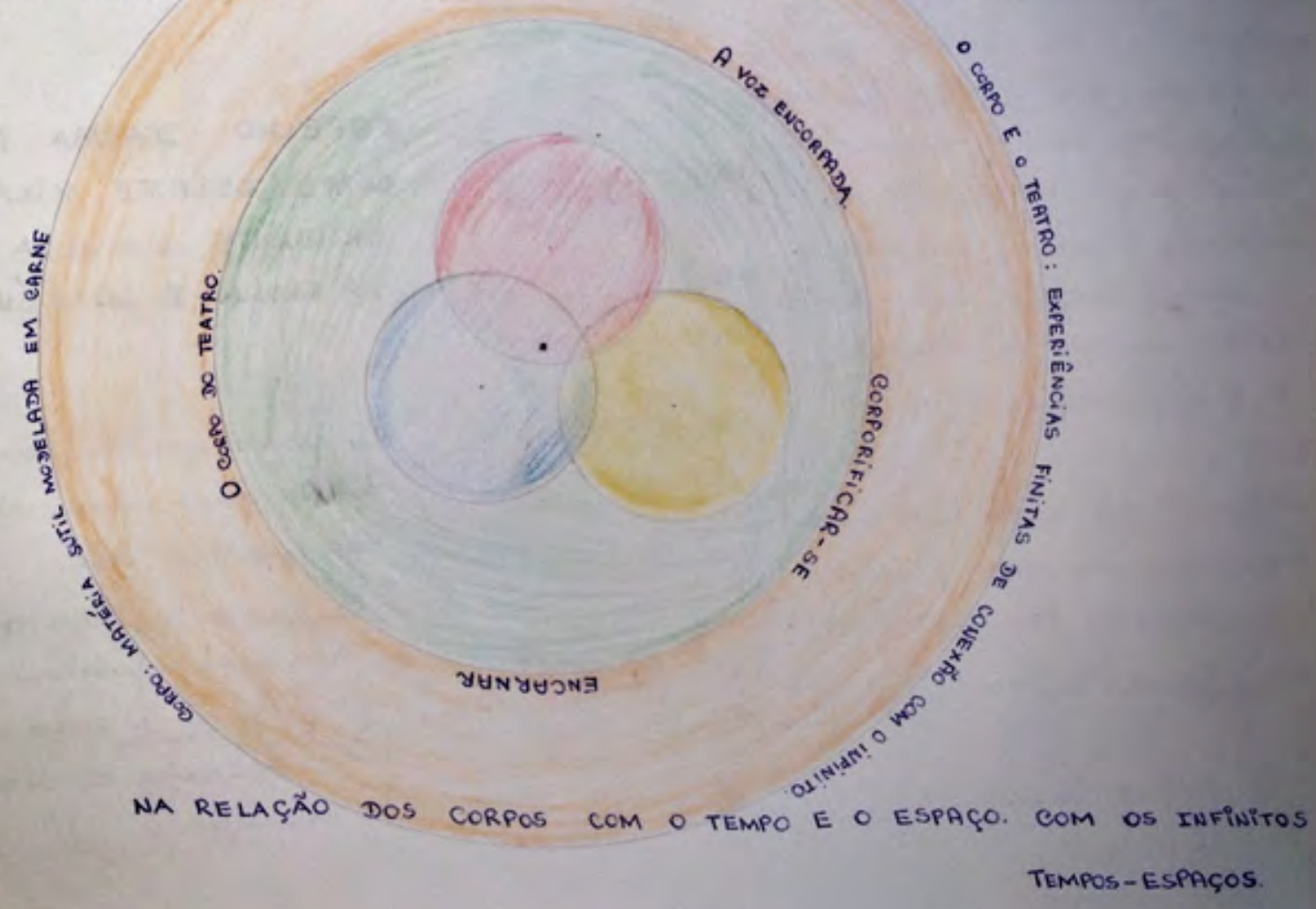

TEMPOS-ESPAÇOS.

Esta foi a primeira escrita, feita no primeiro caderno de relatos coletivo, em 2012, quando ainda nem havia escrito o meu projeto de mestrado. Por esta época devorávamos o texto de Eleonora Fabião, Corpo Cênico, Estado Cênico, e arriscávamos os primeiros passos na cocriação de uma prática para a atriz que transita por diferentes linguagens, a AtriZ eM TRÂNSTIO, Reconheço, neste texto, sentimentos, conceitos, palavras, reflexóes e sentidos que acompanham a pesquisaexperiência desde o início e vão maturando-se e (re)criando-se na nossa vivência... 


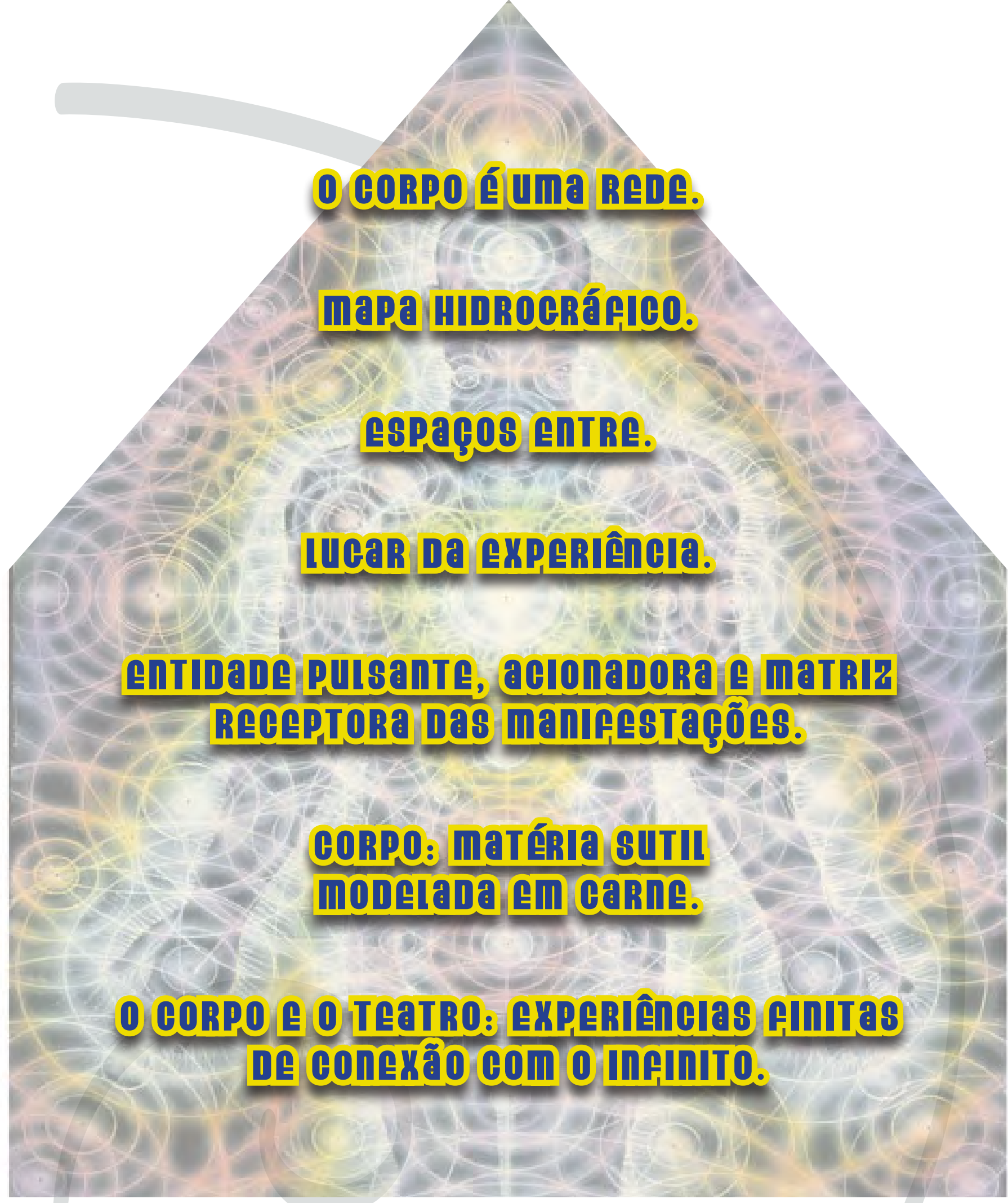

Para iniciar a conversa sobre o corpo e os caminhos que trilhamos nesta pesquisaexperiência, considero importante compartilhar que, quando faloescrevoevocoinvoco a palavra cORPo, apesar de ela estar no singular, ela compreende todos os nossos sete corpos que compóem o corpo, desde o corpo de matéria mais densa - o físico - até o de matéria mais sutil - o espírito. Os nomes dos nossos corpos variam de uma tradição para outra ${ }^{13}$, e esta pesquisaexperiência, dentro dos seus limites de tempo e espaço, não se propõe a denominá-los de uma maneira específica, nomeá-los, hierarquizá-los; antes, quer, a partir do $\mathrm{T}^{\text {rabalh }} \mathrm{O}$ CRiativo, sensibilizar os nossos diferentes corpos conectivos (suas presenças), desobstruir os canais de conexões entre eles, despertar as possibilidades perceptivas de cada qualidade de corpo e suas inteligências, para que trabalhem em rede, sejam a rede que são.

\footnotetext{
13 Trago aqui um exemplo de denominação utilizado por Charles Leadbeater, em seu livro Os Chakras - os centros magnéticos vitais do ser humano: Corpo Físico, Corpo Vital, Corpo Astral, Mente Instintiva, Intelecto, Mente Espiritual e Espírito, que em sânscrito correspondem respectivamente a Sthula, Linga-Sharira, Kama-Rupa, Kama-Manas, Buddhi-Manas, Buddhi e Atma.
} 


\section{CORPO então significa coRPOS.}

Ainda, quando falo de corpo, estou também falando de voz, pois voz é corpo e corpo é voz. Neste caso, como ainda há uma tendência coletiva a separar as coisas, ao invés de integrá-las, escolho usar a palavra coRPovZ para ativar a consciência dessa integração. E, quando me refiro a uma "tendência coletiva", estou completamente integrada neste sistema. Durante toda a pesquisaexperiência, o trabalho é ativar e manifestar essa integração (a consciência sistêmica) em cada ação criativa, seja na prática de criação de exercícios ou de cena, seja quando escrevo a dissertação, seja quando atuo na peça.

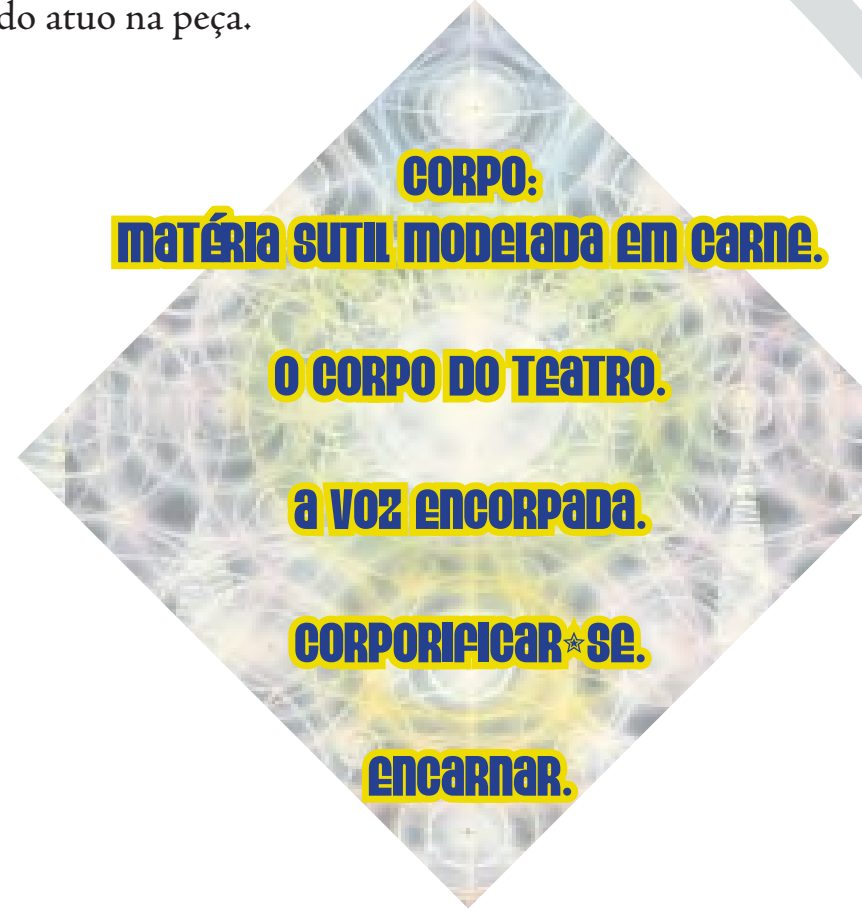

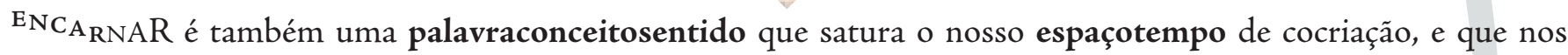
interessa estar em relação, pois todas as experimentações, sensibilizações, devorações, problematizações que fazemos pretendem

\section{ENCARNAR EM ARTE, EM OBRA ARTÍSTICA:}

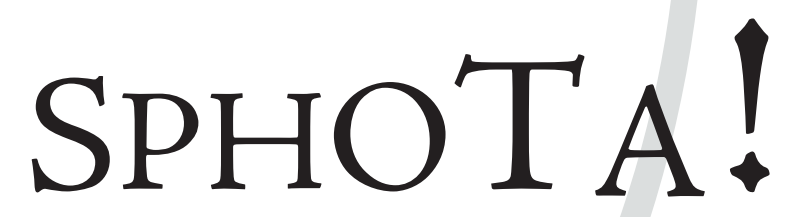


A segunda escrita deste mesmo Caderno de Relatos foi feita por um ator, Thiago Freitas, que saiu do grupo em 2012, mas trago aqui, pois ela manifestaencarna mais um interesse nosso de investigação: a ESCUTA.

\section{CADERNO DE RELATOS I}

(Relato de Thiago Freitas, sem data/2012)

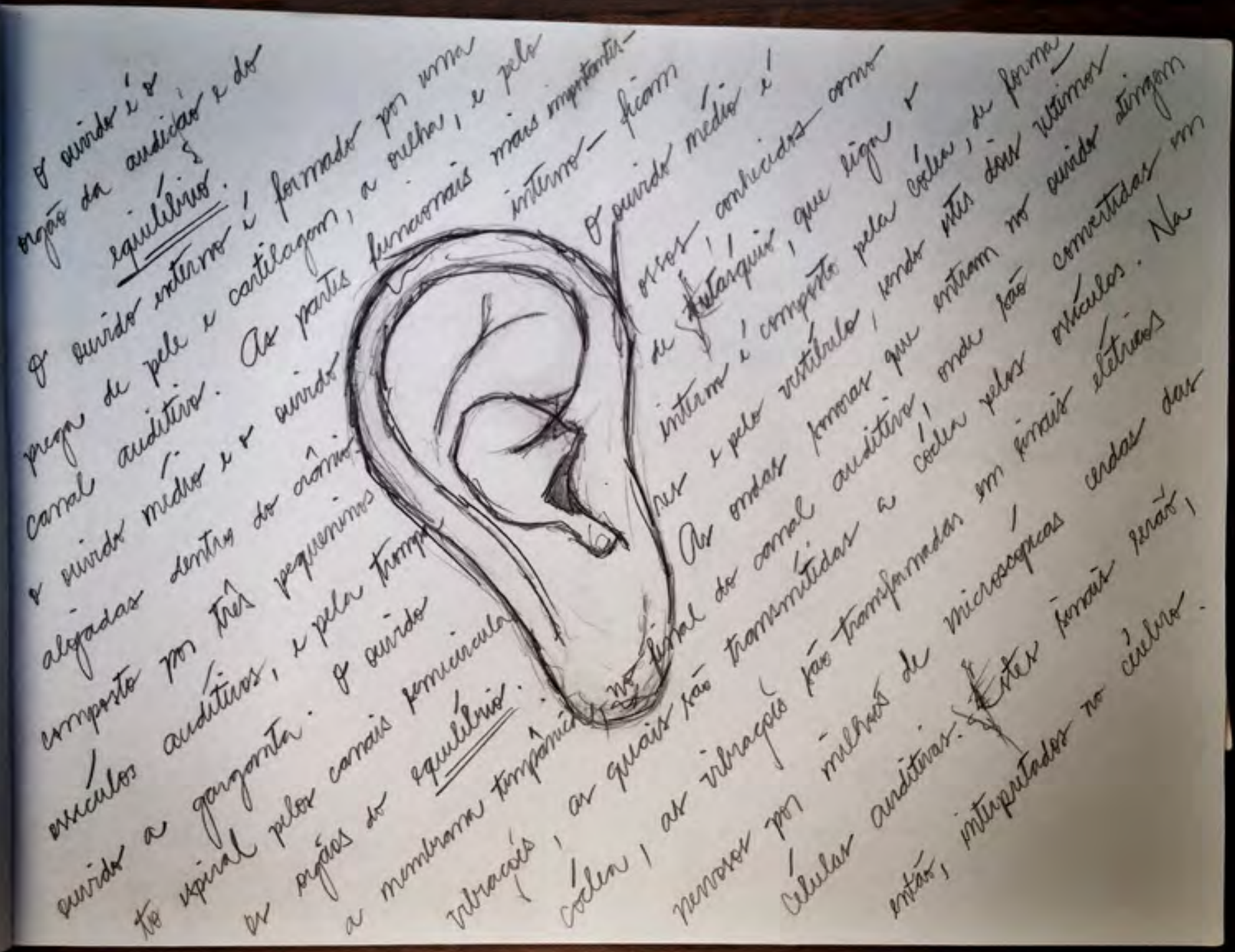

Estes são os relatos mais antigos que temos da nossa experiênciapensamentoinvestigaçãotrabalhosensação com o corpovoz. E desde sempre ela foi cocriada, mesmo as artistas que passaram pelo grupo e pelo processo, e que não estão mais no trabalho, doaram e receberam sentidos deste SiSTeMa que é esta pesquisaexperiência. É muito interessante retornar a esses escritos e perceber de onde começaram a surgir os desejos e necessidades de investigação que nos fizeram caminhar, encontrar com outras vozes, devorar outros materiais artísticos e teóricos, 
CADERNO DE RELATOS II

(Relato de Renata Vendramin, 16 de novembro de 2012)

94) Humano Eletrico Amarelo $16 / 11 / 12$

Treinamente Poítico-Estético.

Corpe-vez em trânsite. T conceito de trânsito incorporado em todos os níveus de trabalko. Cada vez que conseguimos incorporá-lo um pauco mais em um dos niveis, reverberase im toda a rede do trabalko.

(-) truino da musculatura do corpo: movimentos báricos, simples, como as vibrantes es exercicios de coluna, que fortalecem i dixciplinam a compe para receler a novo, para que a eriatividade tentha um terreno fítil para se materializar.

As regiaús de trânsito da voz: reguöes dos chacrias plexs solar e laríngeo. Estar e transitar! Saber ocupar - naber Aransitar.

São regǘs da coluna que muitas pessoas tim probtemas.

A BOA HORA é AEORA. Múrica de Alessandra Leäo trazendo uma referência de canto brihante com apois. (O) coupo canta, a música danģa, a palavia narrada í música.

A onda vibuacional que ela emana nos faz acessar e reconte ar lugares. Ela nos aferece um lam exemplo, uma boa prática. Canto terra-cér.

49 


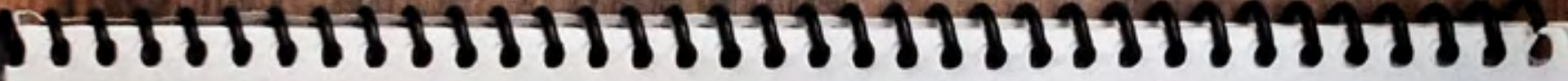

Sinto desejo de comegar a trabahkar tem com referencias de dança e movimento. Assim como estamos fazendo com as narrativas e músicas.

Acho bem productivo as treinamentos coxpo-voz sem a presença das navrativas propriamente ditas, pois quando elas estä, a palavia ainda tende a ter uma suprema cia.

Este foi o primeiro dia que fizemos a relato juntas do caderno. E lemos uma para a autra.

No relato acima falo sobre a experimentação de um treinamento poético-estético ${ }^{14}$, no sentido de trabalharmos corpovo $z^{15}$ para a artistacriadora encarnar a sua poética ou o seu discurso cênico (compreendendo discurso aqui como elaborações de sentidos múltiplos, não só racionais, não só através das palavras, do discurso falado). Não exercitamos o corpovoz para executar determinado padrão corporalvocal, abrimos espaçotempo para a artistacriadora expressar-se, entrar em contato consigo mesma, liberar a sua energia criativa, manifestarvibrar os seus fluxos e ritmos criativos, descobrir os seus

\section{MOVIMENTOS POÉTICOS COCRIADORES DE sEntIdOS ES e m s En Tid OS.}

Nesta época, em fins de 2012, transpirávamos o conceito da ATriZ eM TRÂNSTO, que transita por diferentes linguagens em cena e que encarna uma consciência sistêmica. A palavra TRÂNSTIO saturava o nosso espaçotempo de cocriação. Trânsito como esse ESPAÇO E N T R E, esse espaço de relação, em que os sentidos e semsentidos se constroem e estão em constante (re)criação.

\footnotetext{
${ }^{14}$ Hoje, olhando para este relato escrito em 2012, quando ainda nem havia ingressado no mestrado, escolheria utilizar "prática poéticaestética", ao invés de "treinamento" ou "preparação", pois, para mim, essas duas últimas palavras trazem uma ideia de uma prática que quer chegar a um lugar muito específico, ou que oferece procedimentos metodológicos bem desenhados para atingir determinado objetivo, o que não é a intenção das práticas vivenciadas e compartilhadas aqui nessa pesquisaexperiência.

${ }^{15}$ No relato anterior, aparece "corpo-voz", com hífen. Era o começo da cocriação do conceito; trilhando os caminhos dessa pesquisaexperiência, achei mais coerente juntar de fato as palavras, pois, com o hífen, elas continuavam separadas, distantes.
} 


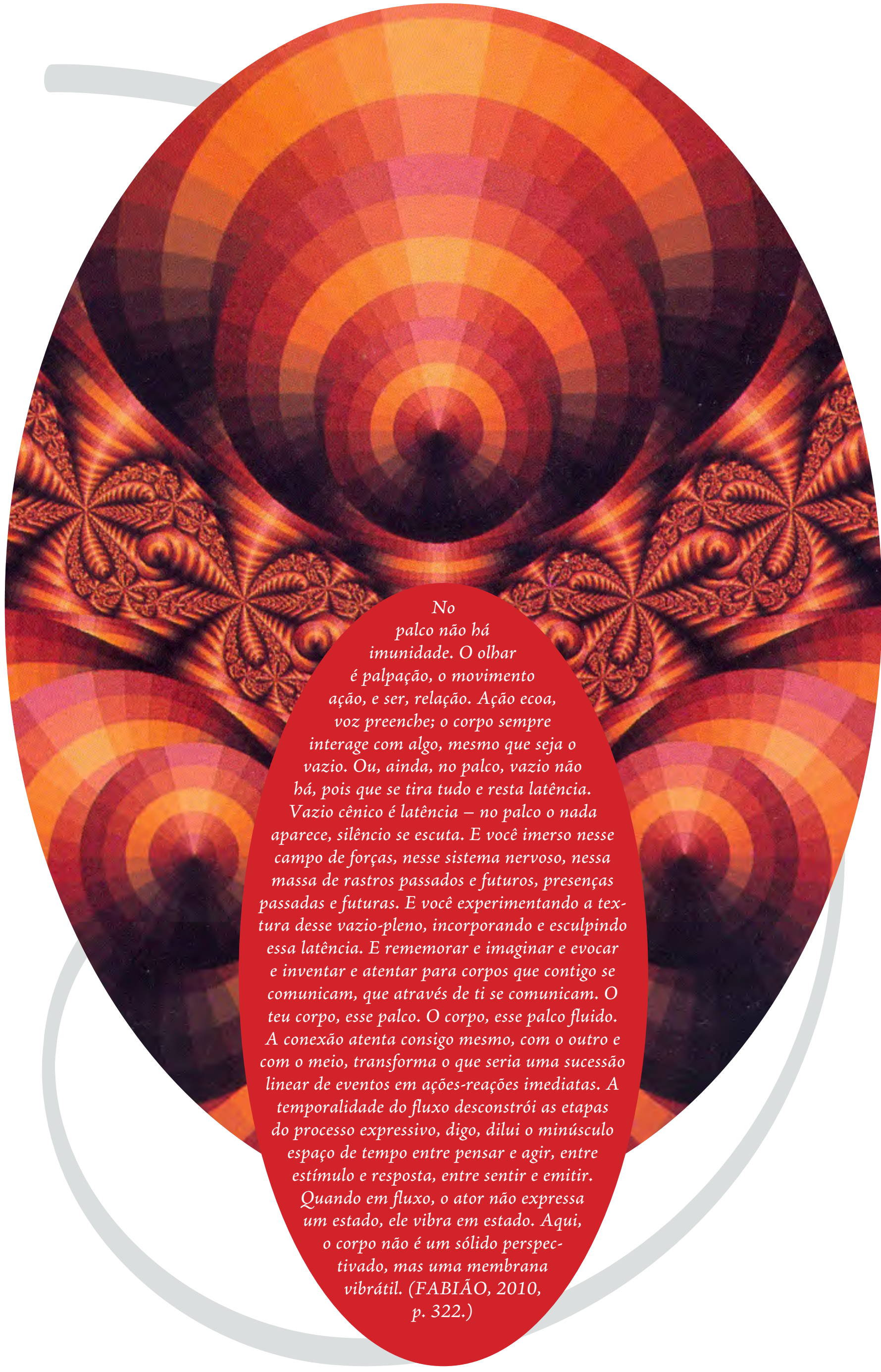


Säe Paulo, 16 de nevembro de 2012 .

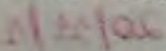

Treinamento CORPO-EXPRESSÁO da FALA - DA Música - dO GESTO POETICO.

Ali onde moram as costebs. Ali mora a contubuccäo para o alinhamento do Corpo- espérito. Ali onde moram es elástucos-diafragma \$ a bexiga abdómen Ali moram as contribuicioes para a expansão. No coypo, em seus múltiplos gesto. vio poútico.

Nós (re) desenhando a merada de cada textura da veg no corpo. (Re) compreundendo a demensão de erganimo no que diz resperto Do corpo. O corpo fala, danca, significa. Pentro dele atuam infinitas linâmuces transformadas em gusto, imagem.

Abrimas espace para falar, na prátera, sobre: TRÂNSiTO entre um expoce e cutre una terctura a outra, una dinamica e outra. S-lreinamento está focado en oBSERVAR es momentos en que acontucen o TRÂNSITO intre un guto e autro. Srabalho tal qual escavacáo dos mundos, poros, teste de ande brotam e flourem PALAVRA, GESTO, ACAO. No intervalo

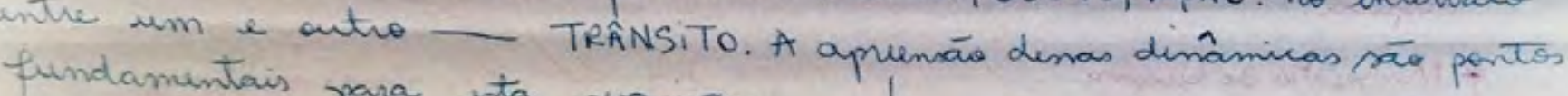
fundamintais para ista perquira.

\section{A BOA HORA}

TREINAMENTO DE PRESENCA CRIATIVA

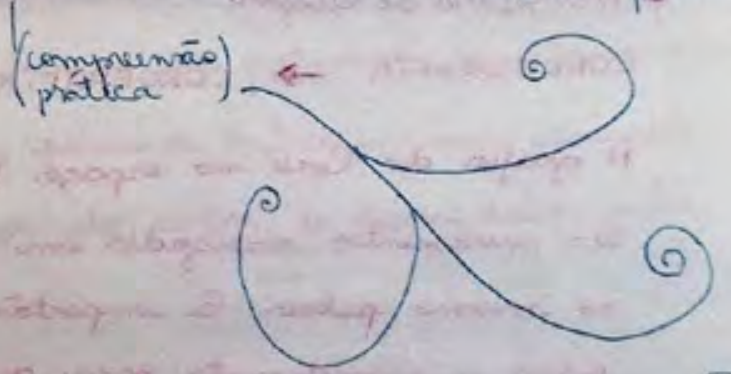

TRÂNSITO CANTADO

CANCAOO TRANSVENDO O CORPO QUE (RE) CONHECE SUA INTEGRIDADE.

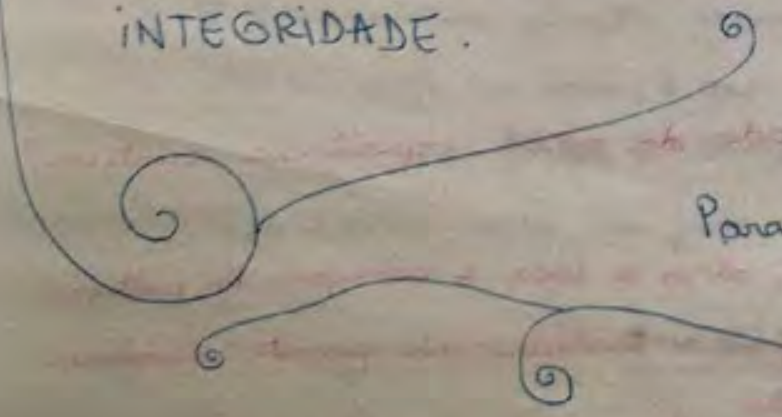

Silencua grándo de nom

Para um getto, mivido que seja, - todo o coppo. Sodo o ser.

L gravidez leta de abdomen, coxtelas pés, ógáos, poves, particulas traba leando am conjunto Trganismo coRPo. 


\section{nO GORPO, en seus múltIPIOs espą̧os, IIORa O pássaro que VOa}

\section{EII DIRȨ̣̃o ao TODO. V00 Em músIca,}

dança, eesto.

\section{VOO POÉTICO.}

O GORpo faIa, dança, sicnifica.

\section{DEITRO DELE aTUam InfInITas DInâmI0as IRansformadas em cesto, Imacem.}

\section{O VOO POÉtICO Da aRTISTagrIanoRa.}

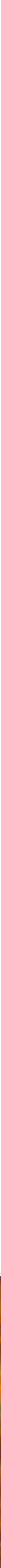


A PEÇA É UM CoRPo.

NOSSOS CORPOS EM CENA FORMAM UM ÚNICO CORPO.

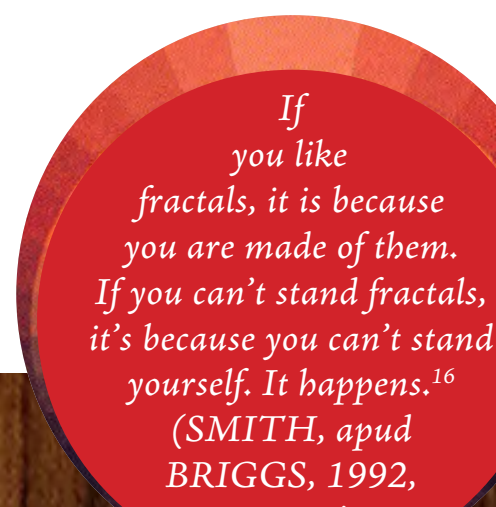
p. 122.)
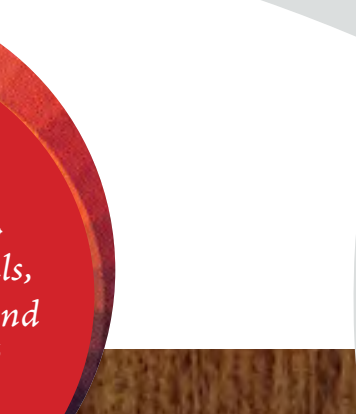

\title{
N5T25
}

CADERNO DE RELATOS II

(Relato de Renata Vendramin, 13 de dezembro de 2012)

\section{$13 / 12 / 12$}

${ }^{16}$ Tradução nossa: "Se você gosta de fractais, é porque você é feito deles. Se você não pode suportá-los, é porque você não pode suportar a si próprio. Isso acontece".

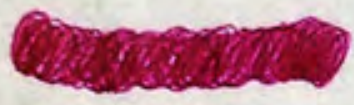

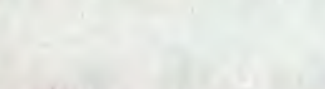

Chegada do tambor da fana. Nois sons graves pulsando. Dois conaçés pulsando.

Sinte que estamos mais conectados, auvindo es seguindo - pulso comum do trabalko. Sinto que o coraç̃o do trabalhando está pulsando es estamos conectadas a ele. E un nome se apresenta: Aivú. Sopro luz primeivo.

Na prática corporal respiramos juntas. A saudaçäo ao sol fita s a mínimo de fala num pulso comum.

A transição de uma prática pl a outra au de uma condução para outra se due c/ a manutençäo do pulso, í um único movimento.

Primuia viz que fazemos a encercício dirita/esquerda com os 2 tambores. Exercicios de ordenação, de alinha mento, de pulso firme, que traz leveza, clareza, integra caro, concentraçäo. 


\section{CADERNO DE RELATOS III}

(Relato de Janaína Silva, 13 de dezembro de 2012)

Aquecimento corpo - voz integrados. Ainda que a patica acanteca em dois momentos, há a convênencia de que as qualidordes dos exencicios sâo

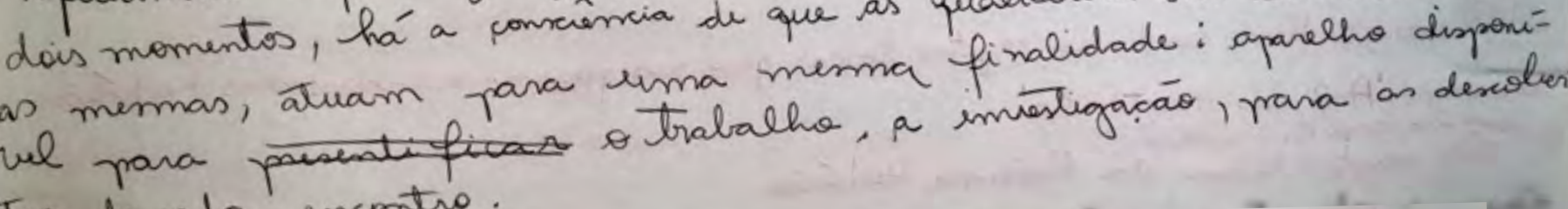
tas de cada encontro.

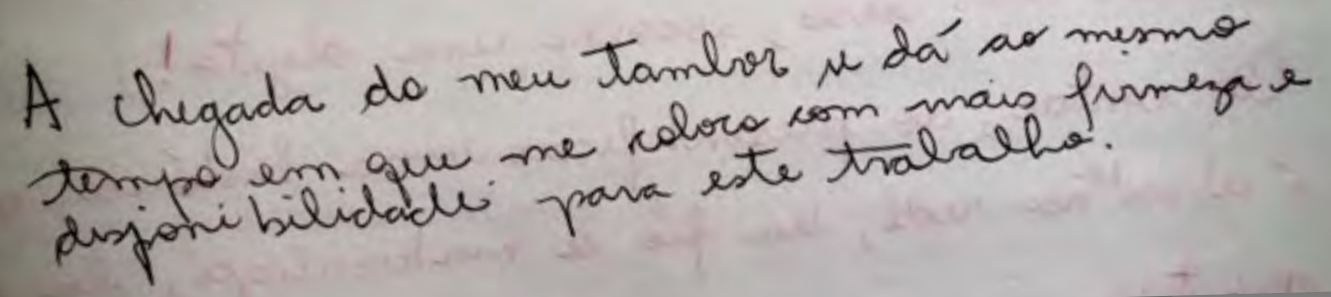

Para começar a trilhar caminhos de sensibilizaçãoconscientizaçãoabertura do corpo da atriz, definimos que compartilharíamos a condução das práticas Janaína e eu, pois neste momento somente nós duas éramos o sistemaprocesso. E, assim, com base em nossas referências pessoais e em materiais artísticos e teóricos devorados (que chegavam a todo momento), colocados em relação, propusemos e fomos criando um rEPERTÓR Io De P R Á T I C A S . Quem definia o que era coerente e comporia nosso repertório de práticas não era Janaína nem eu, era a ressonância da proposição nos nossos corpos e no sistemaprocesso. Normalmente percebíamos em acordo o que era coerente ou não. Fomos cada vez mais percebendo juntas o que era pertinente, conforme refinávamos o trabalho da ESCUT A - escuta de nós mesmas, escuta do outro, escuta do sistemaprocesso.

Não é um escutar passivo, dissociado lcomo se existisse algo pronto e

fosse só uma questão de baixar esse conteúdo do campo da consciência humana). Parece que a coisa está se formando na medida em que eu a escuto.

Trata-se de ir construindo esse órgão de ver/escutar o mundo enquanto possibilidade - sentir isso, ir com vivendo com as coisas na essência e potencialidade delas, "adivinhando" o movimento que elas querem fazer. É um escutar dinâmico, pois requer mover-se com a

coisa, prestando atenção se está havendo agarramento por

identificação com uma dada expressão que ela está tomando.

0 próprio escutar - e não tanto o que se escuta - vai alinhando

forças dentro e fora. Escutar catalisa, principalmente se não colocamos a estática do interesse próprio ou de receios que distorcem a sinalização. ${ }^{17}$

\footnotetext{
${ }^{17}$ Entrelaçamento com o texto da página 33.
} 
Para sensibilizar a ESCUTA e alcançar níveis mais profundos de compreensão e vivência desse estado, trabalhamos com nossos tambores. Podemos perceber nos relatos acima o dia em que Janaína comprou o seu próprio tambor e trouxe pela primeira vez ao ensaio. Eu já tinha o meu, e usávamos outro que era do grupo, mas alguma coisa se moveu dentro dela, quando ela começou a praticar com o seu próprio tambor.

Compartilho duas práticas que realizávamos juntas com os tambores, que passaram a compor nosso repertório de práticas.

O SoM dO cOrAçÃo: cada uma em seu tambor, marcávamos o som do coração no centro do instrumento (som grave). Cada dia uma começava dando o andamento do som do coração (mais lento ou mais rápido). Ficávamos um tempo (um bom tempo), no mínimo 15 minutos, fazendo o toque do coração e respirando juntas.

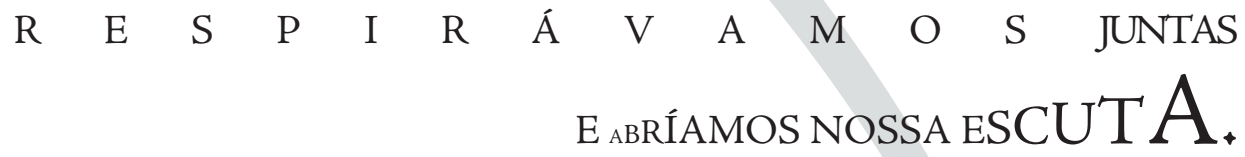

Tínhamos que ser precisas para a manutenção do andamento do toque e, ao mesmo tempo, ter flexibilidade, pois poderia haver pequenas variações de andamento desde que as fizéssemos juntas. Eram dois tambores, dois corações (neste caso) pulsando juntos. Encontrando um pulso comum, em que já não sou eu ou ela, mas o nosso encontro, a nossa relação, o sistemaprocesso pulsando.

\section{O CORAÇÃo DO SiSTeMa P R O C E S S O $P$ U L S A N $D$ O. oCORPO do SiSTeMa P R O C E S S O vivo.}

SINGLE BEAT COMBINATIONs ${ }^{18}$ : cada uma em seu tambor, realizávamos a sequência de toques indicada na folha abaixo, variando as mãos direita e esquerda, sendo que $\mathrm{R}$ significa right (mão direita) e L, left (mão esquerda). Cada dia uma começava dando o andamento do toque.

Começamos fazendo a sequência uma vez. Na primeira ocasião, foi extenuante mental e fisicamente. $\mathrm{Na}$ ânsia de acertar a sequência de variação da mão direita e esquerda, não respirávamos, assim ficávamos ansiosas em realizar, deixávamos o andamento mais rápido, por vezes nos perdíamos no meio, ficávamos sozinhas, cada uma tentando acertar o seu... Praticamos e, realizando o toque em conjunto, fomos encontrando a respiração, a escuta e a concentração necessárias para fazer a sequência uma vez, duas, três, variando o andamento. Normalmente começávamos com o toque mais lento e depois deixávamos um pouco mais rápido. Ganhamos experiência na prática, o que não garantia que, todas as vezes que praticávamos o exercício, ele acontecesse com primor, sem interrupção de seu fluxo. Se nos perdíamos, voltávamos ao início.

${ }^{18}$ Este exercício trouxe das aulas de percussão que fazia individualmente.

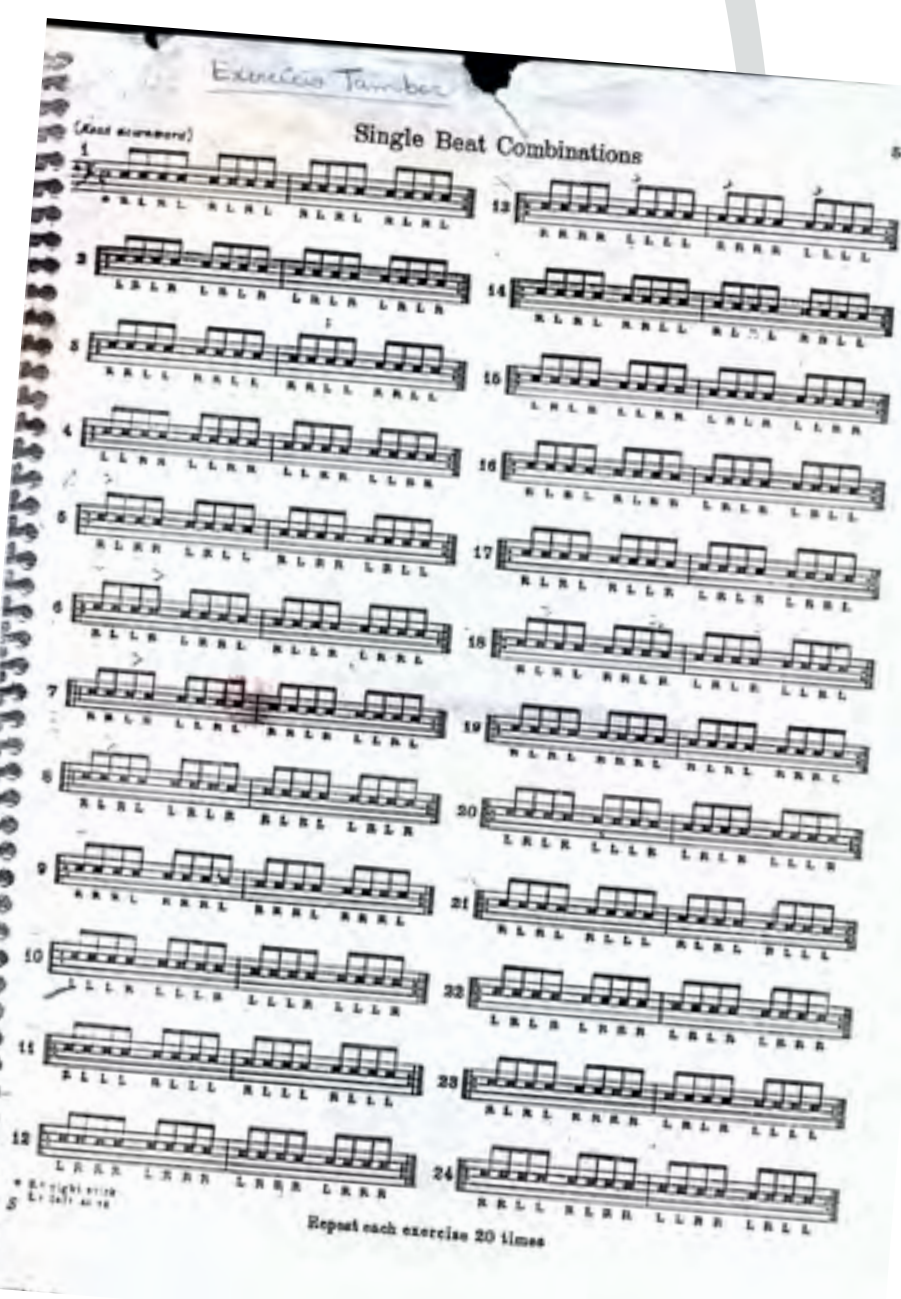


Ambas as práticas têm um caráter meditativo, em que passamos um tempo repetindo uma ação conjunta com outra(s) pessoa(s) e percebendo a nossa própria respiração. Uma M E D I T A Ç A 0 ATIVA EM RELAÇÃO. Após realizá-las (algumas vezes começávamos o encontro com elas, outras fazíamos em seguida de exercícios em que movimentávamos o corpo físico), sentíamos a nossa percepção mais sensibilizada, tínhamos (como falamos nos relatos acima) sensação de alinhamento dos corpos, de maior concentração, mais presença no espaçotempo de cocriação, de integração com o outro e com o sistemaprocesso.

\section{a S E N S I B I L I Z A Ç A 0 do CORP0 em ESCUTA.}

Com práticas como essas mexíamos no nosso corpo, na nossa terra - esse campo fértil. Deixávamos a terra fofa, úmida, desejante de gerar e gestar sementes criativas.
4

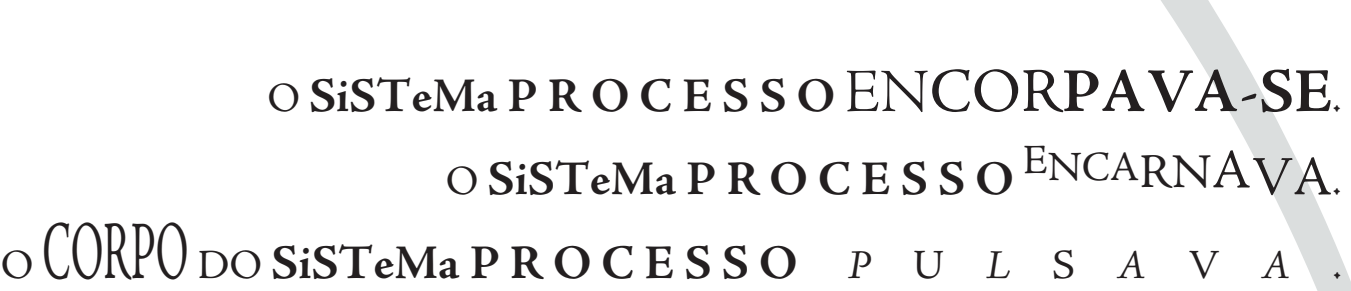

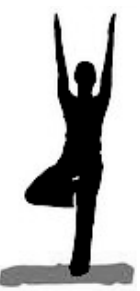

\section{CADERNO DE RELATOS III}

(Relato de Renata Vendramin, 04 de julho de 2013)

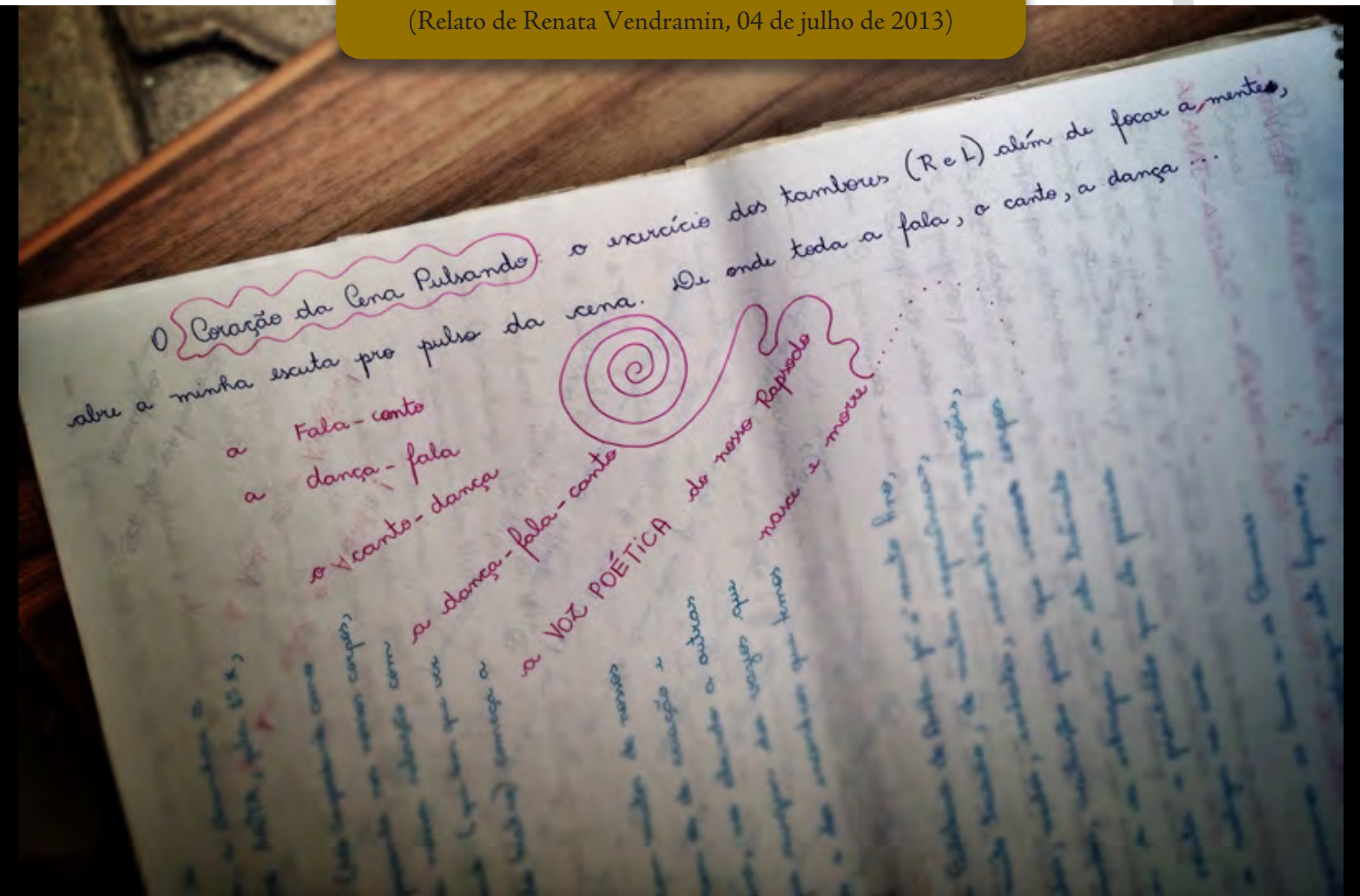


Neste fluxocompartilhar das trajetórias percorridas é sempre importante lembrar que a criação e/ou prática desses exercícios aconteciam simultaneamente à criação e/ou prática de exercícios de criação de cena, das colheitas de narrativas, da devoração de materiais artístico e teóricos, do compartilhar de propostas de cenas para a peça e também de dramaturgias escritas. Um movimento inter-relacionava-se com o outro, alimentando, iluminando ou findando um ao outro.

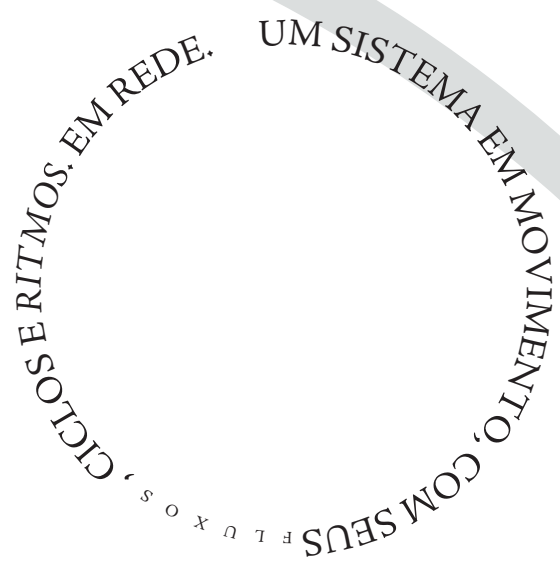

Movendo-se na dança deste sistema, chegaram ao nosso espaçotempo de cocriação os movimentos do yoga, a partir da minha referência de prática corporal ${ }^{19}$. O yoga reconhece o nosso corpo como um grande sistema (composto de inúmeros outros sistemas) e nos ensina caminhos de conscientização, relação e sensibilização do nosso corpo de maneira sistêmica, através das posturas físicas, dos exercícios de respiração, relaxamento, concentração e meditação. A palavra yoga significa "união", "integração".

Propus trazer práticas do yoga para o nosso sistemaprocesso. Hoje acho mais assertivo chamar de $M V_{V}$ I $\mathrm{ME} N \mathrm{~T} \circlearrowright \mathrm{S}$ DO YOGA, em vez de usar posturas, asanas ou qualquer outro nome que possa relacionar com uma prática mais "pura" do yoga. Considero mais coerente com o processo de devoração do yoga dentro do contexto desta pesquisaexperiência que acontece no campo das artes cênicas.

O yoga e a maneira como aprendi e escolhi conduzir as práticas trouxe consigo também o princípio da escuta, do respeito, da delicadeza, da suavidade, da gentileza com o próprio corpovoz: dar passos, evoluir, fortalecer, ultrapassar limites sempre de maneira pacífica e amorosa. Uma possibilidade mais $\mathbb{Y} \mathbb{N}$ de relação com o corpovoz.

Com isso, abrimos espaços internos e fortalecemos a musculatura envolvida no processo respiratório por meio de exercícios de respiração; azeitamos os espaçosentre das articulações; trabalhamos com alongamento e flexibilidade; torcemos, fizemos flexões (frontais e laterais) e extensões na coluna vertebral; fortalecemos nosso senso de equilíbrio, a percepção do nosso centro; trabalhamos com concentração; entramos em contato com os movimentos internos do corpo (pensamentos, emoções, sensações, sentidos), podendo, dessa maneira, perceber nossos

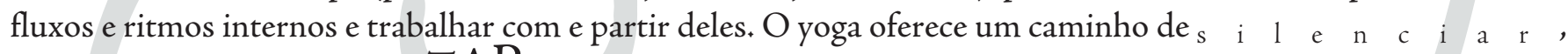
que é, ao mesmo tempo, esCUTAR os movimentos internos e externos.

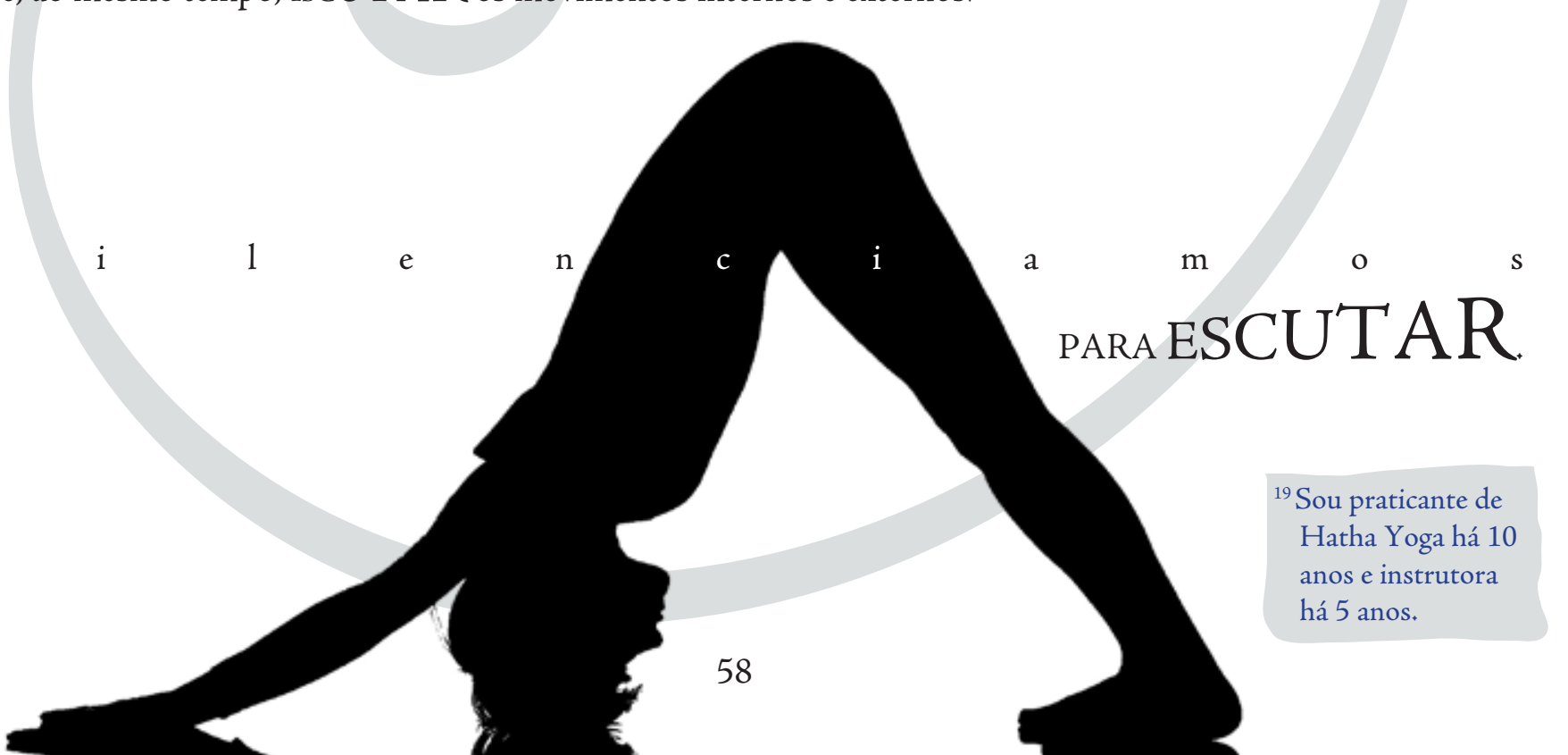


CADERNO DE RELATOS II

(Relato de Renata Vendramin, 27 de fevereiro de 2013)

Treinamente

Exercícios aquecimento/sensibilizaçäo Quadrul e Peito (Chacra Raiz e Esplenico e Cardíace). Alurtura Espace Vazio interno.

Deitados. Respiracăo bauxa, pés unidos, joelhos pi lateral. Torçäe / Eleva e baixa quadril / Ganche dedäo; alonga Siquência lombar

Siquência pernas (se precisar com faixa) Vira de buicos Serpente

Serpente pegando punho

Alongamento 7 mbeo

Arco

Vajuásana, alenga braços a frente, volta Guro caleça im vajräsana

Alre puto

Deita: Halásana, invertida.ombros invertida cabega

9 sequincia base Surya Namaskar $\}$ Para aumentar - Ix com' Pacifisto 1 o batimento cardíáco

- 20z: enrolamentos com vruuluu on massageando internamente zuoa

Seguir para OESPAÇO DO CíRCULO, pl improvusaçäo de A mais zelha que o tempo.

59 
O trabalho com os movimentos do yoga ativa e faz fluir a energia criativa que mora na base da coluna vertebral, a BUND A L NON, liberando o nosso fluxo e ritmo criativos, permitindo que entremos em contato com nossa criatividade genuína, em plena e íntegra conexão com nosso espírito. Todos os corpos em comunicação, em fluxo, em relação.

\section{A COLUNA SERPENTEANDO}

A coluna investigando possibilidades de existir nas torções, flexões, extensões, inclinações laterais a partir dos movimentos do yoga. Conjugamos o verbo serpentear...

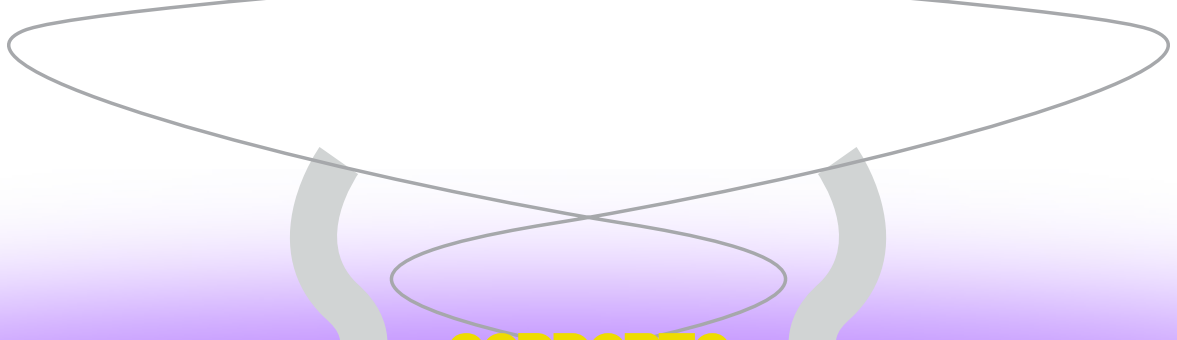

SERPEITE

ว์cua

FIUXO

FE III InO

FORGa VITAI

FERTILIDODE

CESTลดูก

SInUOSIDADE

\section{SERPEDTEAR}




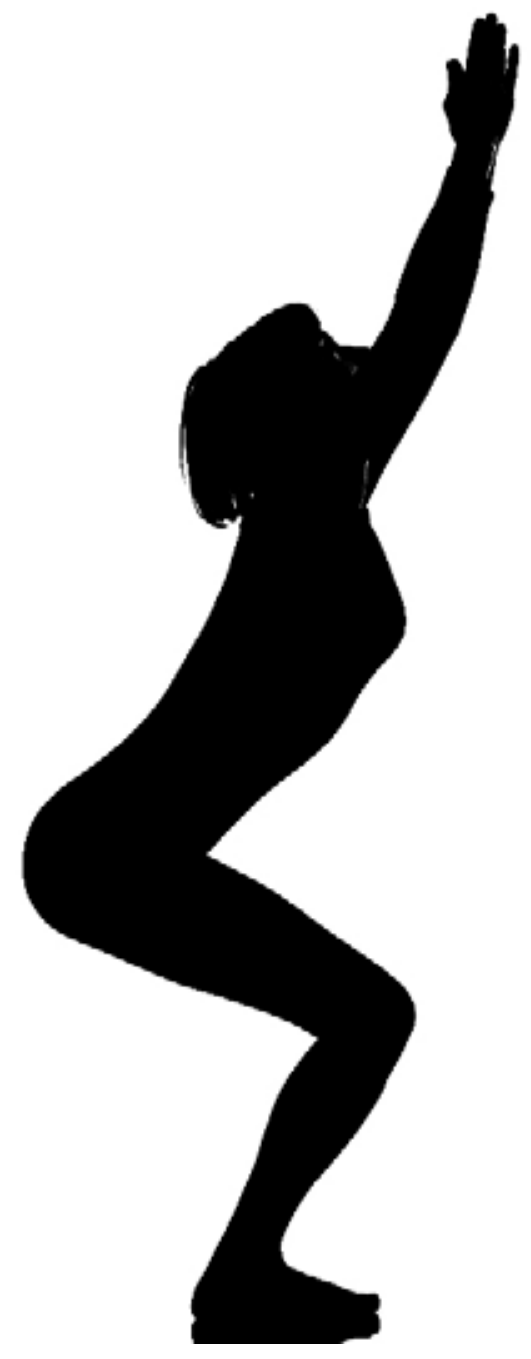

Naturalmente, imersas no fluxoinspiração do trabalho corpovoz, algumas práticas vocais foram sendo integradas aos movimentos do yoga, por exemplo:

- Na respiração do tigre (feita em quatro apoios, quando inspiramos, fazemos uma extensão na coluna; quando expiramos, fazemos uma flexão), incluímos o som de $\mathrm{S}$ na expiração.

- No movimento de enrolar e desenrolar a coluna (em pé ou sentadas), acrescentamos um vibrante na descida e o som de $\mathrm{S}$ na subida.

Fomos experimentando possibilidades de integração de movimentos vocais aos demais movimentos do corpovoz.

\section{A voZ EM MOVIMENTO, O MOVIMENTO EM VOZ.}

Além dos movimentos do yoga praticados individualmente e integrados com os movimentos vocais, experimentamos trabalhar com a sequência de movimentos da Saudação ao Sol ${ }^{20}$ (Surya Namaskar). Usamos duas variações da sequência, uma que é realizada em pé (plano alto) e outra que é realizada sentada (plano médio). Quando nós duas já estávamos familiarizadas com as sequências, praticávamos juntas, lado a lado, em silêncio, com a escuta e a pele sensíveis para executarmos os movimentos em sincronia, no mesmo ritmo, sem que para isso nenhuma de nós precisasse se impor, colocar-se na direção, na condução por meio da voz ou do movimento. Sentíamos juntas qual era o ritmo do dia, colocando nossos movimentos internos em relação e, a partir daí, definíamos o ritmo da prática comum, íamos ajustando o ritmo, realizando a sequência. EM RELAÇÃO. EM COCRIAÇÃ O.

\section{CADERNO DE RELATOS II}

(Relato de Janaína Silva, 04 de julho de 2013)

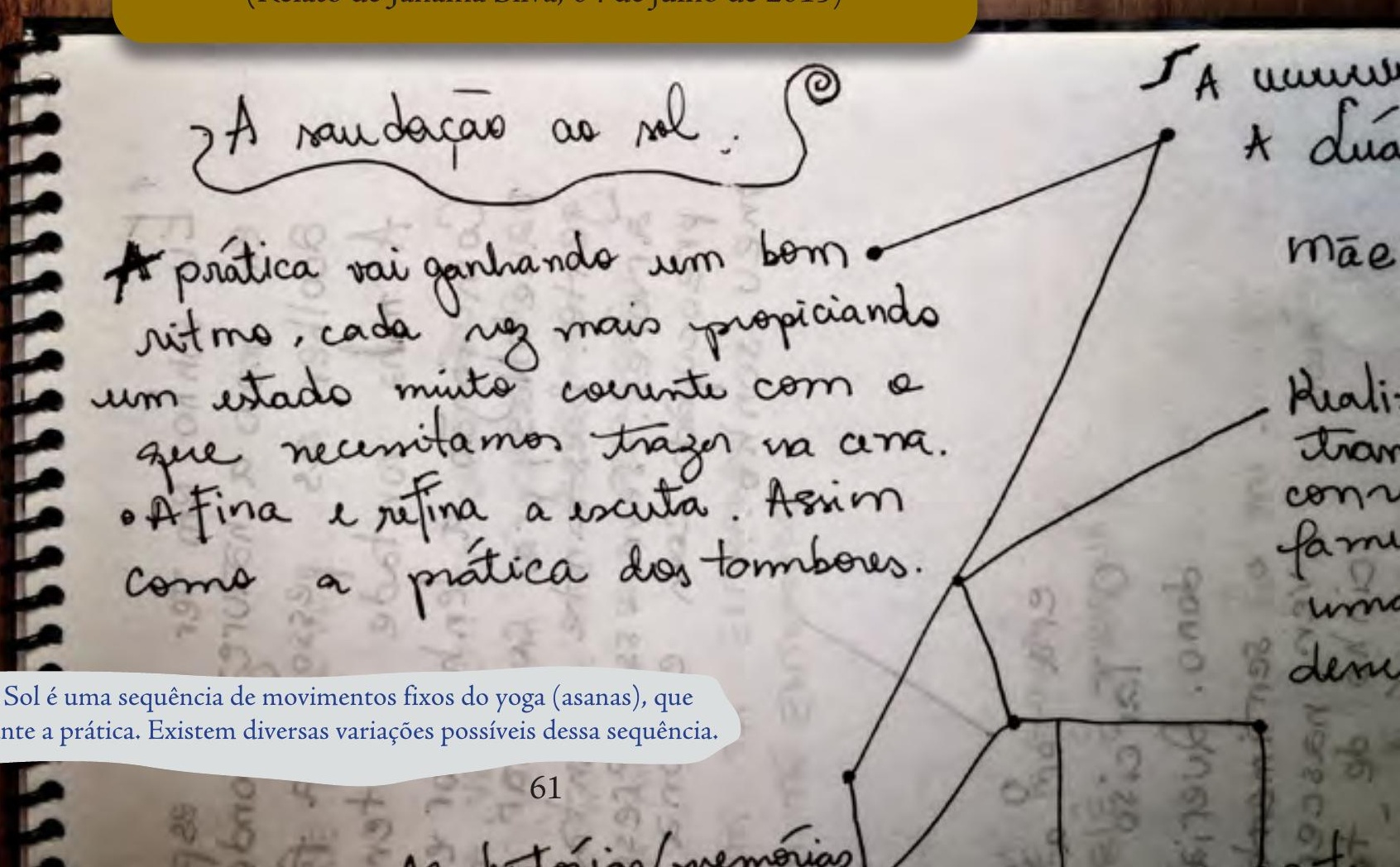

A Saudação ao Sol é uma sequência de movimentos fixos do yoga (asanas), que é repetida durante a prática. Existem diversas variações possíveis dessa sequência. 
$\mathrm{Na}$ construção desta práticapensamentocorporalvocal, também conectamo-nos e relacionamo-nos, através da voz de Capra, com o pensamento chinês e seu conceito de YG] e YANG. Mais um pensamento oriental milenar, assim como o yoga, que ressoava no nosso espaçotempo de cocriação.

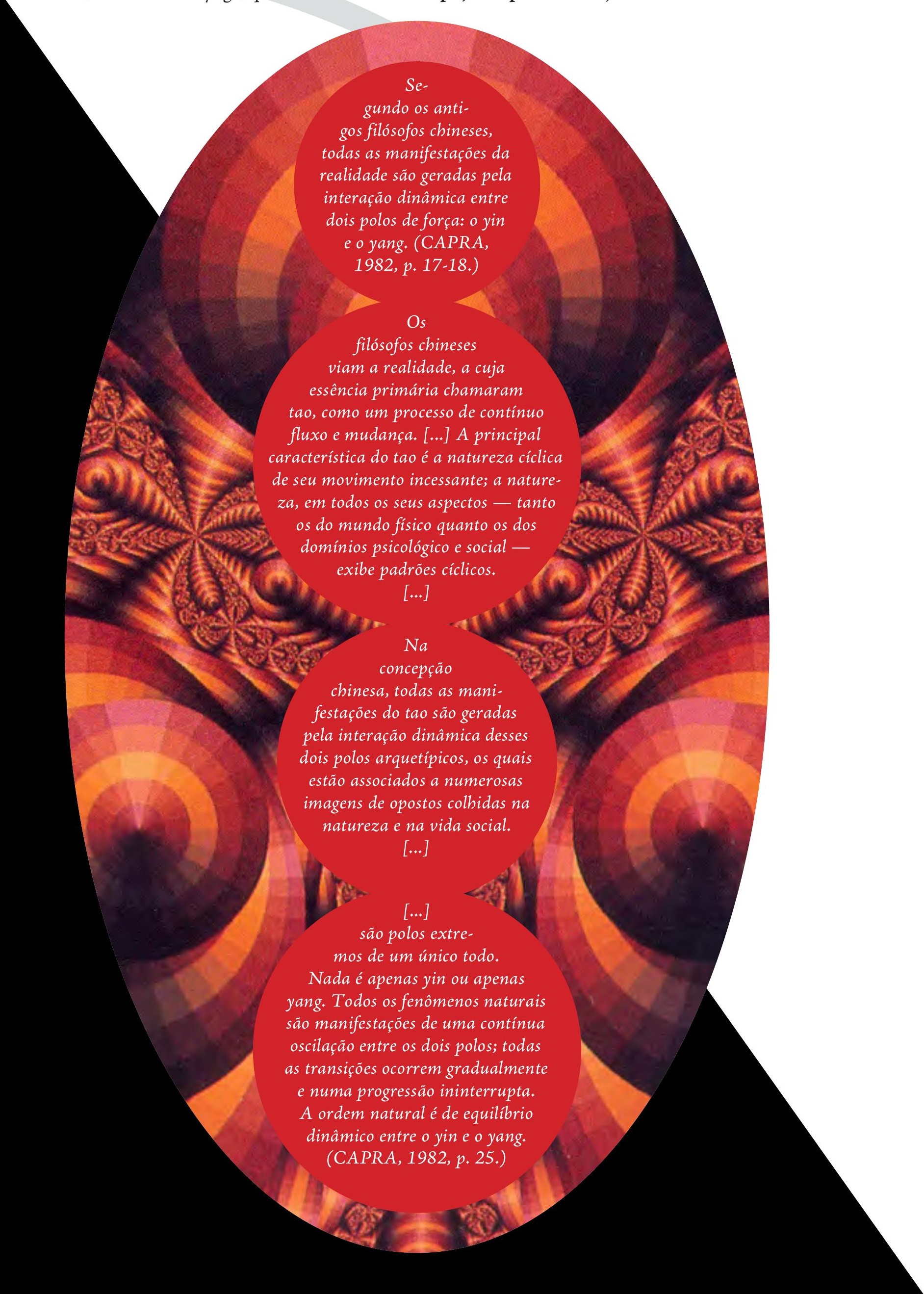




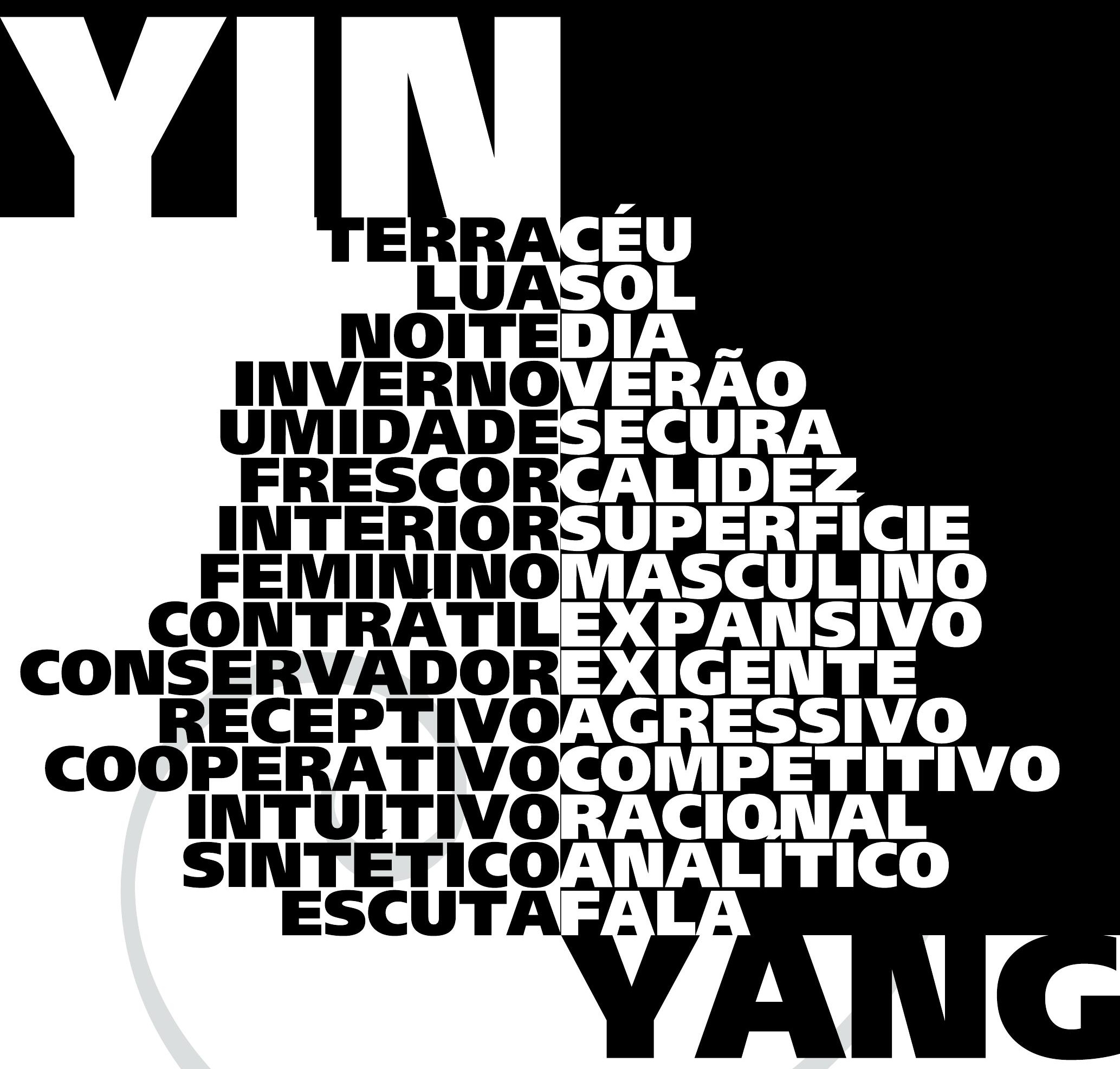

Tendo

yang atingido seu climax, 
O nosso trabalho com a ESCUTA, com a DISPONIBILIDADE, com a RECEP TIVIDADE, com a s u tile za, a d e li c a d e $z$ a, como caminhos de sensibilização do corpovoz e de cocriação manifesta

o nosso desejo de um equilíbrio, ou por vezes uma exacerbação consciente, da energia ỸâN em nosso sistemaprocesso.

O pensamento do Taoísmo, trazido na voz de Capra, em seu livro O Ponto de Mutação, ecoou de maneira harmônica e sincrônica em nosso espaçotempo de cocriação, quando entramos em contato com ele. Pareceu-nos coerente essa necessidade de cocriarmos um espaçotempo de experiências para

\section{MANIICESTARMO-NOS MIN}

\section{VIBRARMOS YMN.}

Segundo Capra no livro O Ponto de Mutação, escrito em 1982 (ano em que nasci), vivemos uma crise de percepção planetária (que se desdobra em problemas políticos, sociais, econômicos, ambientalistas, espirituais), e dentre os fatores responsáveis está a cultura patriarcal que alimentamos e reproduzimos há cerca de três mil anos, cujas doutrinas são tão preponderantes, aceitas e arraigadas em nosso modo de sentirperceberexistirorganizar o mundo, que são confundidas como sendo "Leis da

Natureza". Esquecemos que a cultura patriarcal foi criada pela imaginação humana (e, antes de ela encarnar, vivíamos em sociedades matriarcais). O patriarcado exacerba as qualidades YANG em detrimento das qualidades WMN, e sua prevalência há três mil anos desrespeita esse processo de contínuo fluxo e mudança, essa oscilação natural e dinâmica das duas forças arquetípicas $\mathbb{Z}$ e

YANG, e estabelece uma relação de dominação sobre as qualidades TIN Essa exacerbação YANG, que perdura há milênios na cultura ocidental (e na sua maneira de organizar a vida e as relaçóes), nos concultura chinesa, o yin

e o yang nunca foram associados a

valores morais. [...] Desde os tempos mais

remotos da cultura chinesa, o yin está associado ao feminino e o yang, ao masculino. Essa antiga associação é extremamente difícil de avaliar hoje, por causa de sua reinterpretação e distorção em subsequentes eras patriarcais.

[...] os antigos chineses acreditavam que todas as pessoas, homens ou mulheres, passam por fases yin e yang. A personalidade de cada homem e de cada mulher não é uma entidade estática, mas um fenômeno dinâmico resultante da interação entre elementos masculinos e femininos. Essa concepção da natureza humana está em contras-

te flagrante com a da nossa cultura patriarcal, que estabeleceu uma ordem rígida em que se supõe que todos os homens são

masculinos e todas as mulheres, femininas, e distorceu o

significado desses termos ao conferir aos homens os papéis de protagonistas e a maioria dos privilé-

gios da sociedade. (CAPRA,

1982, p. 25.) 
De volta ao nosso microcosmo, ao nosso sistemaprocesso, que como um fractal ressoa a estruturapensamento do macrocosmo, começamo-nos a fazer perguntas, propor reflexóes sobre a nossa maneira de agirsentirvibrarexistirmanifestar-se:

- Como está o equilíbrio dinâmico das energias $\mathbb{Y} \mathfrak{\mathbb { N }}$ e $\mathbf{Y A N G}$ em nosso sistemaprocesso? Em nosso sistemacorpovoz? E na relação entre nossos sistemascorpovoz?

- Como dar-se tempo e dar-se espaço para experienciarmos outras possibilidades de proporções de equilíbrio dessas duas qualidades de energia, sem cair no equívoco de "querer que as qualidades $\mathbb{W} \mathbb{N}$ dominem", acontecendo apenas uma troca de poder (ação de caráter $\mathbf{Y A N G}$ inclusive)?

A voz de Capra ressoando no nosso espaçotempo de cocriação deixou-nos mais conscientes do nosso desejo de encarnarmos ações criativas de caráter YANG e trouxe-nos novos desafios para lidar com essa RECEP TI VI$D A D E$, essa passividade, que é muito diferente do que estamos acostumados a pensarviver sob nossas lentes patriarcais.

O wu-wei chinês, a "não-ação":

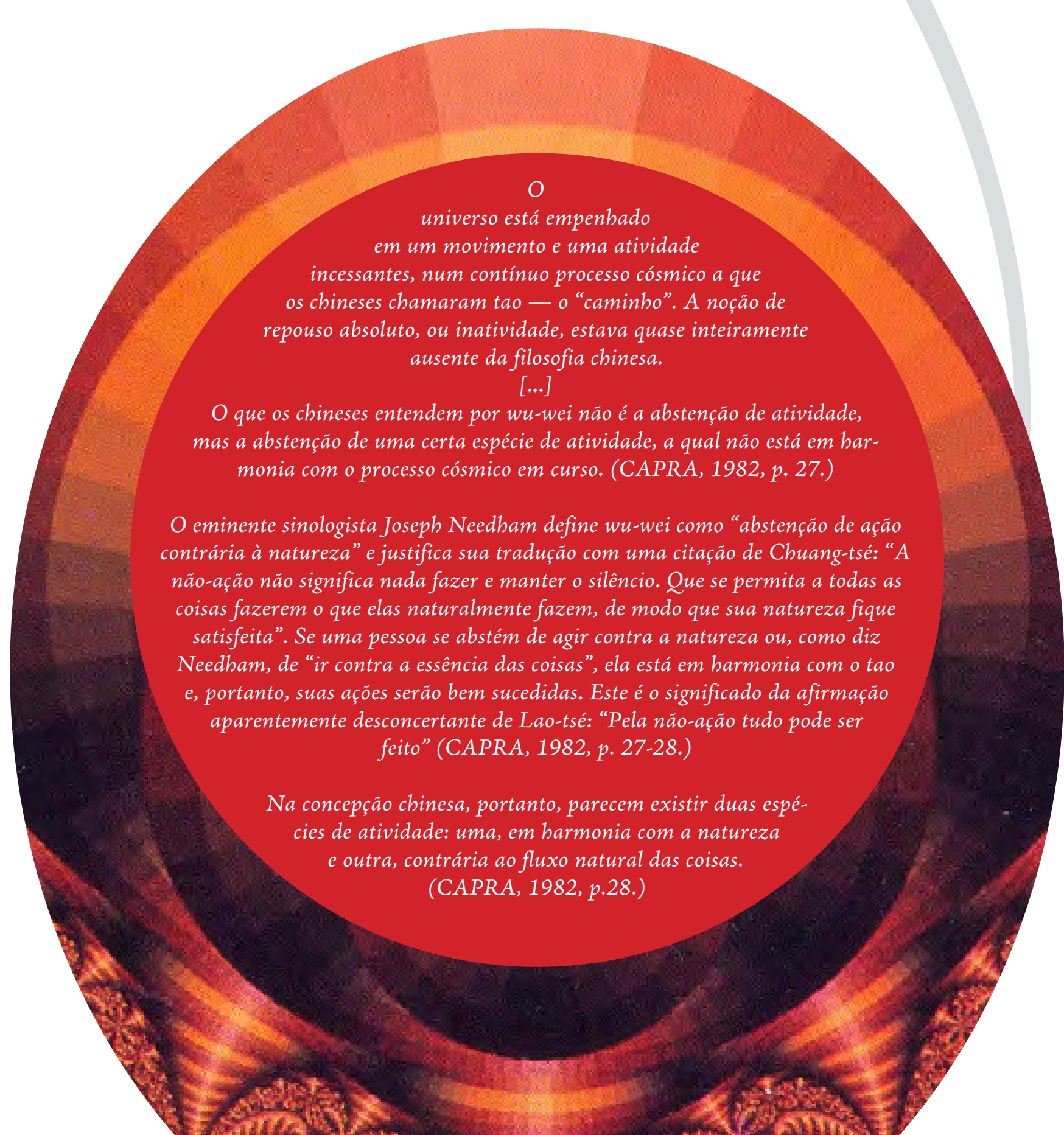


- Que qualidade de disponibilidade, receptividade, abertura, maleabilidade, passividade é essa?

- Como experienciar uma "não-ação", que é uma qualidade de ação que não se impõe, que significa a abstenção de uma certa espécie de atividade? Como encarnar uma qualidade de ação que acontece em harmonia e fluxo com seu contexto - considerando que o nosso contexto é o sistemaprocesso de cocriação de uma peça teatral?

Compreendemos aqui que o ESTADO DE HARMONIA não é um estado ausente de conflitos, contradições, diferenças e transformações. É um estado em que vivemos e integramos os conflitos, as contradições, as diferenças e as transformações, alcançando outros níveis e possibilidades de organização e vivência, a partir das experiências de ${ }_{\mathrm{R}}$ Eorganização e ${ }^{\mathrm{R}}$ Ecriação vividas a cada novo conflito ou transformação.

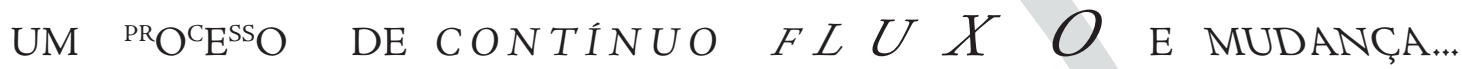

em que as mudanças coerentes e necessárias são percebidas e encarnadas por todos que coabitam determinado contexto. Uma experiência de COcRIAÇÃ $\mathrm{O}$.

A voz de Eleonora Fabião encorpa a conversa:

\section{Para ati-}

var circuitos relacionais,

o ator deve trabalhar tanto no sentido de aguçar sua criatividade como sua receptividade.

Geralmente a criatividade é privilegiada em detrimento da receptividade, a força criativa em detrimento do poder receptivo. Estamos mais habituados a agir do que a distensionar, a ponto de sermos agidos; somos treinados para criar e executar movimento, não para ressoar impulso; geralmente sabemos ordenar e dar ordens ao corpo mais e melhor do que sabemos nos abrir e escutar. A busca por um corpo conectivo, atento e presente é justamente a busca por um corpo receptivo. A receptividade é essencial para que o ator possa incorporar factualmente e não

apenas intelectualmente a presença do outro. (FABIÃO, 2010, p. 323.)

\section{A BUSCA POR UM CORPO CONECTIVO, ATENTO E PRESENTE É JUSTAMENTE A BUSCA POR UM CORPO RECEPTIVO.}

O corpo não é receptáculo ou recipiente (anuncia Merleau-Ponty), mas "tecido conectivo;" o mundo não é receptáculo ou recipiente, mas tecido conectivo. O palco, matriz de conec-

tividade, é corpo, é mundo, é mundo-corpo e
corpo-mundo. (FABIÃO, 2010,

tividade, é corpo, é mundo, é mundo-cor
corpo-mundo. (FABIÃO, 2010,

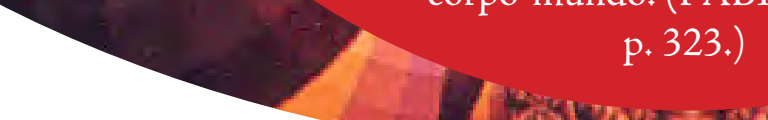


Deixamos ressoar e assentar no corpovoz as vozes trazidas ao espaçotempo de cocriação e também os conteúdos devorados por essas vozes (como o Taoísmo por Capra)

\section{COM TODO O CORPOCONECTIVORECEPTIVO}
A
B
E
R T
$\mathrm{O}$
EM ESCUTA.

Com que qualidade interna eu perscruto algo que está se tecendo?

Eu me disponibilizo para tudo que estiver chegando -

ou só para o que eu torço que aconteça?

O meu escutar é um trabalho junto com as ocorrências ou eu fico

lamentando situações que são colocadas ou tiradas?

Com que sentimento eu me coloco diante das forças

vivas que estão desaguando em nós?

\section{Eu deixo isso atuar?}

\section{Eu sinto os pontos de resistência?}

Todo o meu ser - as minhas células, nervos, poros, tudo recebe essa água com alegria?21

Compartilho duas práticasmovimentos, que integraram nosso repertório, em que partimos do trabalho da voz para trabalhar o corpovoz. Ambas foram trazidas para o espaçotempo de cocriação a partir das nossas referências pessoais, da nossa formação como artistas e mostraram-se bastante coerentes, conforme foram sendo devoradas e exercitadas. Aos poucos ocorreram modificações, e as práticas ganharam variações possíveis.

O S 0 M Dos/Nos CHACRAS ${ }^{22}$; emissão das vogais nas regiões dos centros de energia do corpovoz, como se a emissão das vogais acontecesse por uma "boca" em cada uma dessas regiões. A inspiração e a expiração acontecem por um "nariz" também localizado em cada uma dessas regióes.

\footnotetext{
Região do quadril/baixo ventre $\rightarrow$ emissão da vogal $U$ (chacras raiz e esplênico).

Região do abdômen (um pouco acima do umbigo) $\rightarrow$ emissão da vogal Ô ou Ó (chacra do plexo solar). Região do peito (centro do peito) $\rightarrow$ emissão da vogal A (chacra cardíaco). Região da garganta (centro da garganta) $\rightarrow$ emissão da vogal Ê ou É (chacra laríngeo). Região da cabeça (centro da testa) $\rightarrow$ emissão da vogal I (chacras frontal e coronário).
}

${ }^{21}$ Entrelaçamento com o texto da página 33.

${ }^{22}$ A palavra chakra, de origem sânscrita, significa roda. Os chacras são centros de energia localizados no corpo sutil (duplo etérico). Existem sete principais chacras, dispostos desde a base da coluna vertebral até o topo da cabeça, relacionados com as glândulas endócrinas e os principais plexos nervosos do corpo físico. Eles são alimentados pelo prana (energia vital) absorvido na respiração e também responsáveis pela distribuição do prana pelo corpo. Os nomes dos chacras em sânscrito são muladhara, swadhistana, manipura, anahata, vishuddha, ajna e sahasrara (do chacra raiz ao coronário respectivamente). 
Normalmente emitimos cada uma das vogais três vezes seguidas, realizando toda a sequência descrita acima (3 vezes $U, 3$ vezes $\mathrm{O}$...). Podemos finalizar emitindo três vezes a sílaba $\mathrm{OM}^{23}$ e, depois, improvisando a emissão de vogais, compondo uma polifonia de vogais em escuta. Podemos realizar essa prática sozinhas ou com mais pessoas. Quando estivermos em mais pessoas, podemos fazer em círculo, de frente uns para os outros, ou de costas. Ainda podemos nos localizar mais próximos ou mais afastados no espaço disponível.

Esta é uma práticamovimento de alinhamento, de abertura de espaços no corpo por meio da voz. Ela concentra, silencia, abre a nossa escuta, expande a respiração pelo corpo. Permite-nos descobrir outras possibilidades de apoio para a voz e harmonizar o espaçotempo (sala de ensaio) e nossas energias (corpovoz) para o trabalho de cocriação.

O CANTO DAS MUTAf̧ÕES ${ }^{24}$ ः escolhemos uma música e nos colocamos em círculo. É um exercício para ser feito pelo menos com duas pessoas. Cantamos uma ou mais vezes a música escolhida juntas e depois somente uma pessoa vai para o centro do círculo cantando a música, enquanto as demais estão na borda do círculo, em escuta. Quando alguém quiser, entra no círculo e canta a música junto com a pessoa que está no centro (em que momento da música estiver); então a pessoa que está no centro vai saindo para a borda e só a que entrou emite o canto. Em algum momento uma pessoa da borda entra no círculo e "pega a onda da música", a que está no centro retorna para a borda, assim sucessivamente, em escuta. Se estivermos em mais pessoas, podemos fazer com uma pessoa no centro, ou duas, ou três, ou quatro. Se tivermos quatro pessoas cantando no centro, precisamos ter mais quatro na borda para trocar com as que estão no centro. É importante seguir a baliza que, pisando no círculo, a emissão da voz começa; pisando na borda, a emissão da voz cessa. Finalizamos com todos retornando para a borda do círculo, cessando a emissão da voz, ouvindo a sonoridade da música que fica no espaçotempo.

Praticamos por um bom tempo, Janaína e eu, o Canto das Mutações com a música Avatar, da cantora e compositora paraibana Cátia de França.

Assim como a voz de Cátia de França, outras vozes de artistascantores foram trazidas para o nosso espaçotempo de cocriação, saturando-o de frequências, vibrações e energias diferentes, que abriam espaços no nosso corpovoz pela simples presença. A maioria deles são compositores ou coautores de suas próprias músicaspoesias, do seu discursomusical, e tem em comum uma voz poética genuína, uma voz em fluxo, em comunicação com todos os seus corpos, com uma qualidade vocalcorporal que nos interessava estar em relação, não para reproduzir ou imitar, mas para deixar ressoar em nossos corposvozes sons que pudessem inspirar nossa trajetória no encontro com a nossa voz poética... prática de escuta, de ressonância... ${ }^{26}$

\section{o ENCONTRO COM A NOSSA VOZ o ENCONTRO COM A NOSSA POÉTICA.}

${ }^{23} \mathrm{O}$ mantra de uma sílaba OM, que vem da cultura indiana, é usado aqui pela vibração que produz no organismo, também sensibilizando e ativando nossas glândulas endócrinas, abrindo espaços no corpo, contribuindo com um silenciar interno e, consequente, abertura da escuta.

${ }^{24}$ Essa prática trago das aulas de canto que faço com Andrea Drigo, pesquisadora, cantora, multi-instrumentista, regente, diretora e compositora, que desenvolve suas pesquisas e práticas dentro da linguagem que ela chama de $\mathrm{O}$ Caminho do Canto (http://ocaminhodocanto.com.br/).

${ }^{25}$ Cátia de França. In: Avatar, 1996.

${ }^{26}$ Entrelaçamento com o texto da página 136. 
Na trilha de sensibilizar e despertar percepções do corpovoz de maneira sistêmica, além do nosso repertório de práticasmovimentos, criamos algumas açõesatividadesmovimentos pontuais para nos auxiliar a entrar em contato com determinada qualidade de energia, de presença, de corpovoz.

Exercitamos o encontro com o feminino (energia WWN) através da relação com a argila. Para isso convidamos um amigo ceramista, Wagner Priante ${ }^{27}$, para nos conduzir nesta viagem ao universo do barro, ao universo do tato, da escuta, do silêncio, do feminino.

Rralizamos o encontro com o Wagner, com a argila. Foi experiencia muito rica, de falar da experiencia do pocesso de criacáa enguanto modelávamos a barro.

A imaters do vaso de
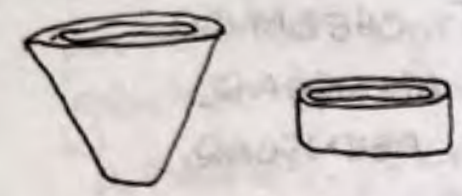

\section{(a)}

barne trás varias metaforas our se conctarn diretamente Do trabralho, as discurroes que intamos trazendo, a

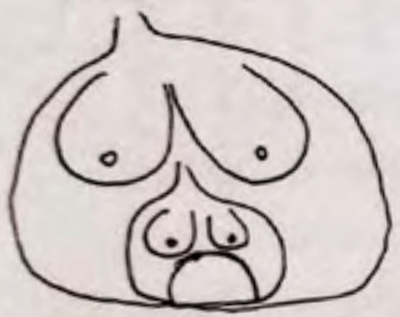
excolha formal, inclusive.

Madelamos wo banno figunas gue representarsem of feminino, a fertilidode.

Toutras possibilidades de acessar os TEMAS as IMAGENS, AS fORMAS, AS cores do processo

${ }^{27}$ Wagner Priante é ceramista, escultor, poeta visual (http:// www.wagnerpriante.com. br/). Wagner participava como cocriador da peça e já havia assistido a alguns ensaios abertos quando o convidamos para este encontro.
Estamos refletindo sobre como Trazer as guntás pusentes no "Ponto de mutracáo" pana a dramatur gia.

I na figura deves sapoodos? 
Modelamos potes ou vasos e uma figura mais livre relacionada ao feminino. Enquanto botávamos as mãos no barro, conversamos sobre a arte da argila, sobre o nosso sistemaprocesso, sobre processos criativos, contamos histórias pessoais, ouvimos o silêncio... trabalhando corpovoz e deixando os sentidos e semsentidos que se criavam em relação ressoarem no barro que nossas mãos davam formas.

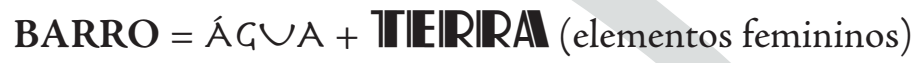

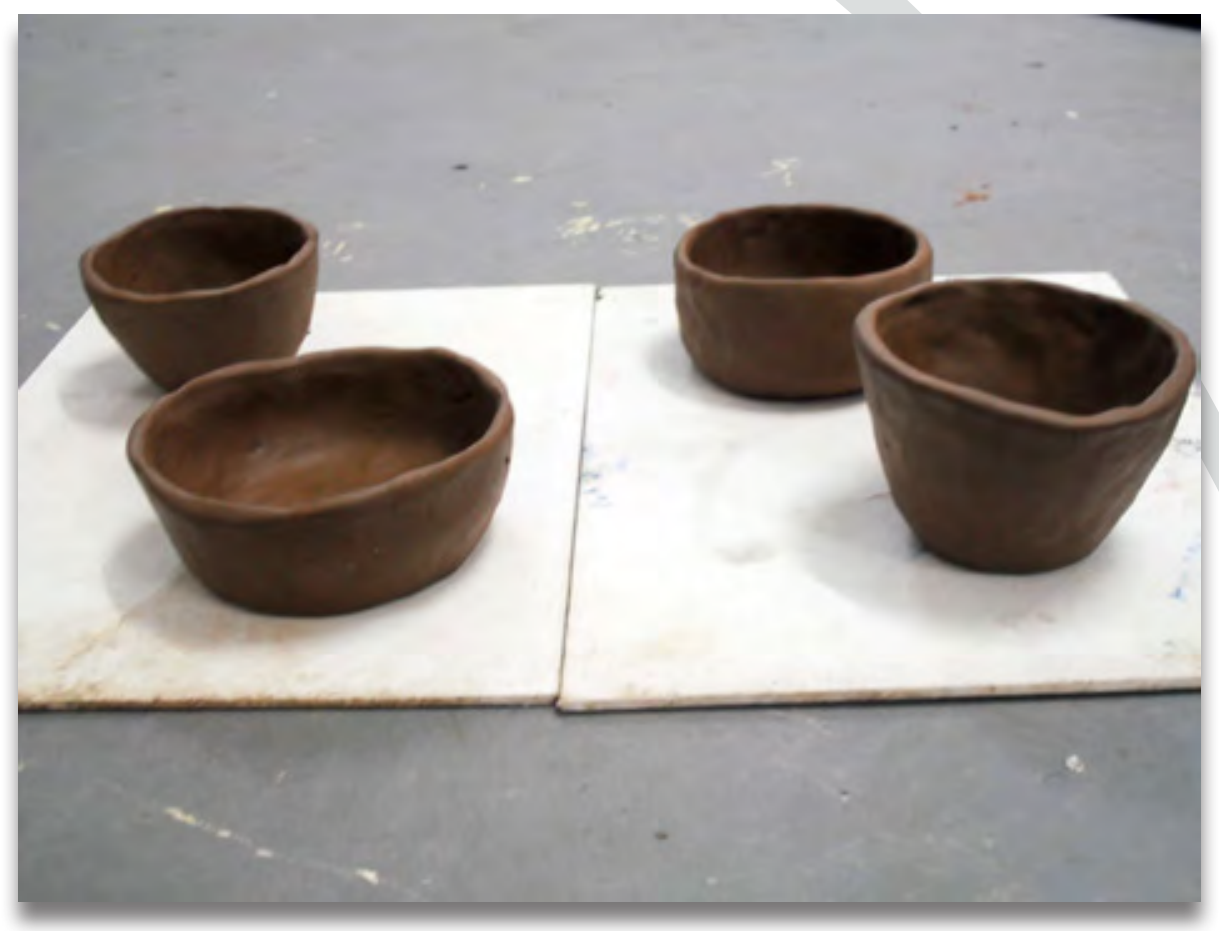

Figura 01. Peças criadas por Janaína Silva e Renata Vendramin. Foto Renata Vendramin.

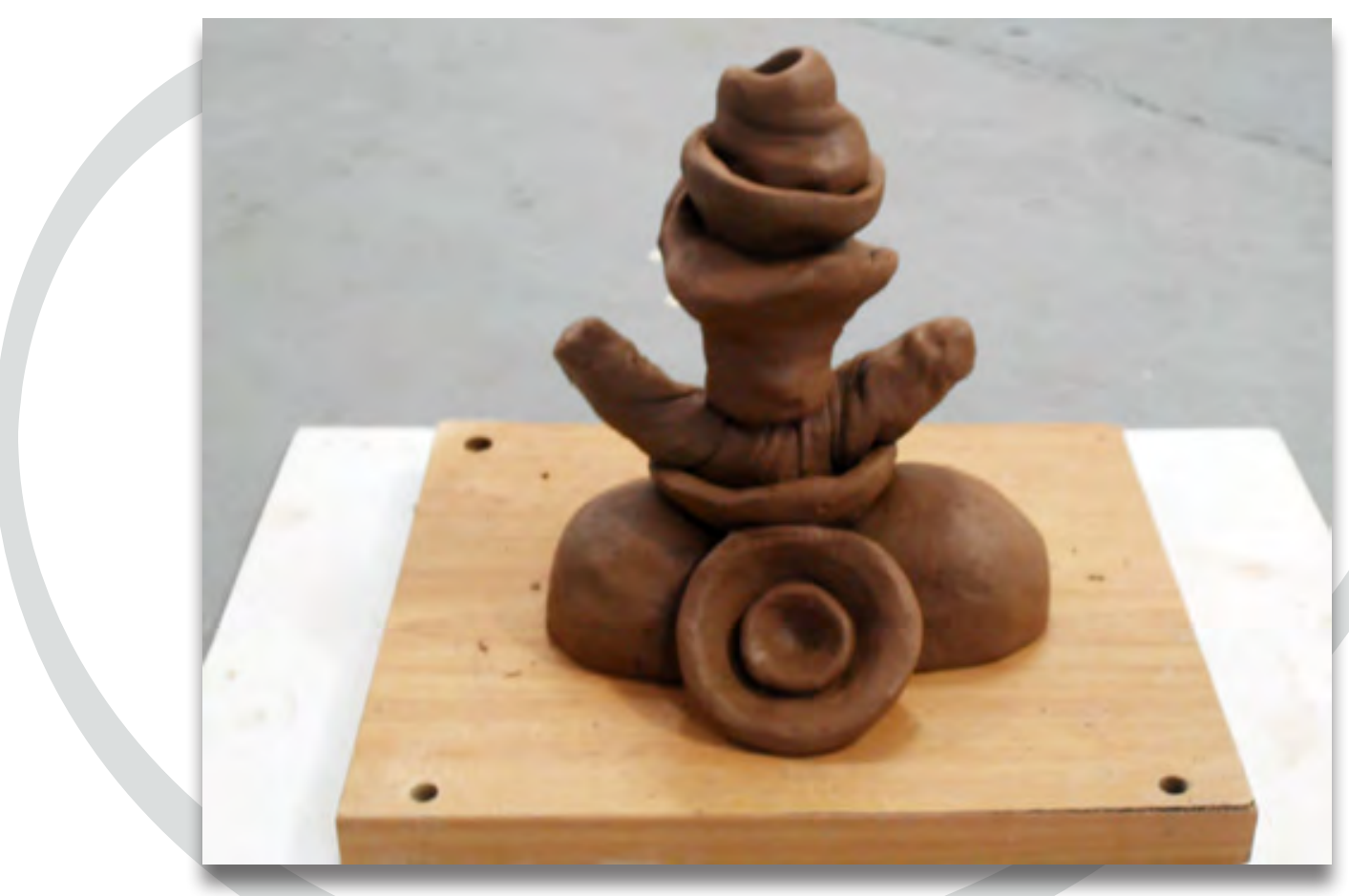

Figura 02. Peça criada por Renata Vendramin. Foto Renata Vendramin. 


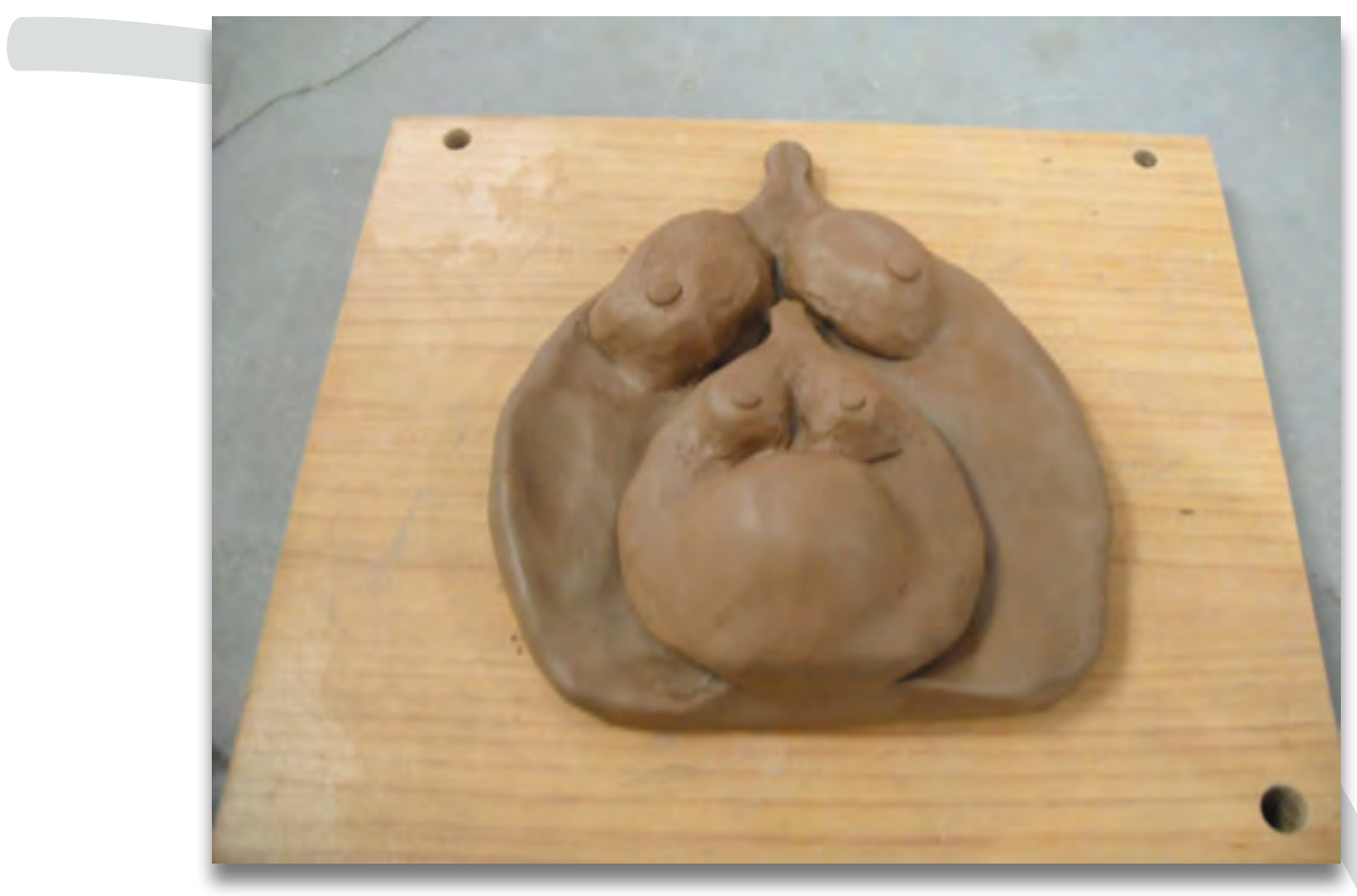

Figura 03. Peça criada por Janaína Silva. Foto Renata Vendramin.

Mais importante do que o resultado formal a que chegamos, foi colocarmo-nos em relação com a argila, em relação uns com os outros, em relação com o tema feminino...

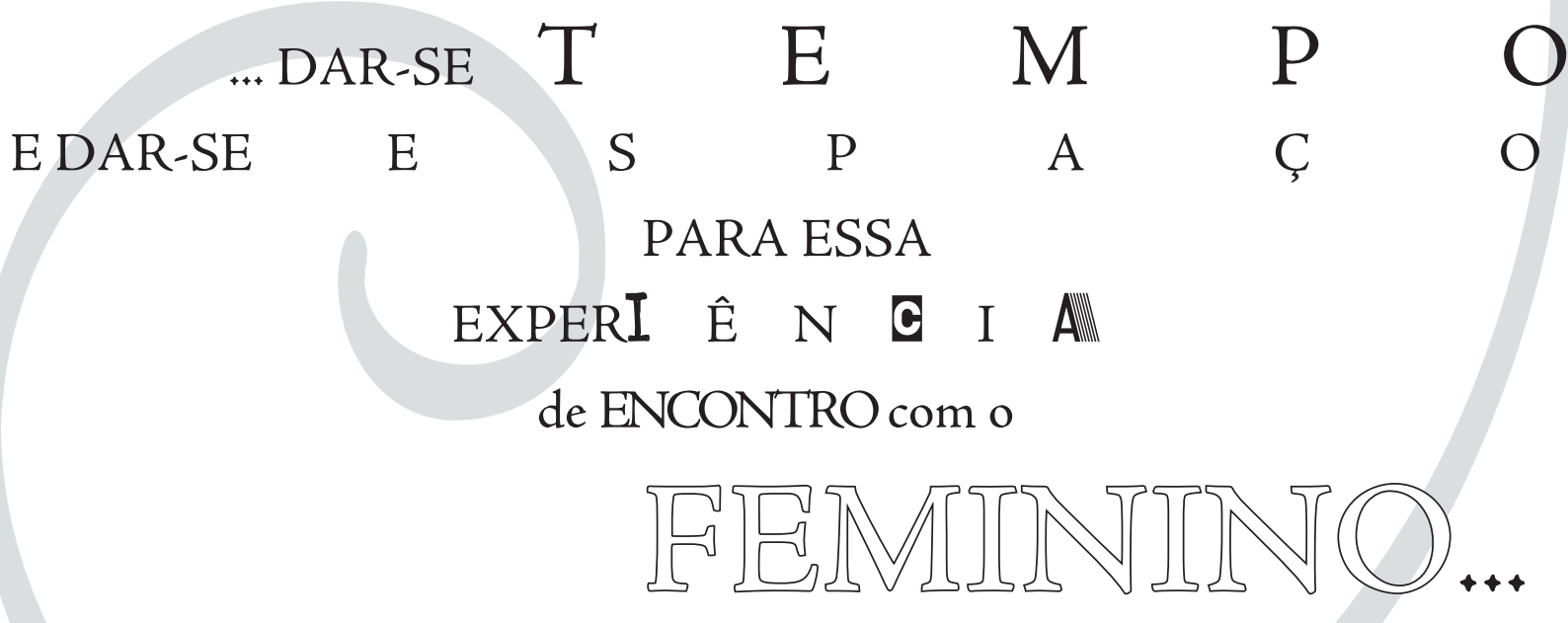

... assentar o corpovoz neste espaçotempo e deixá-lo sensibilizar-se, buscar caminhos de percepções por meio da relação com a argila e todas as demais relaçóes ativadas em rede pelo encontro. É o mesmo princípio dos movimentos do yoga: assentar o corpo em determinado asana e relacionar-se com o mundo, sentirperceberexistircriar desde este ponto de vista, desde esta postura. 


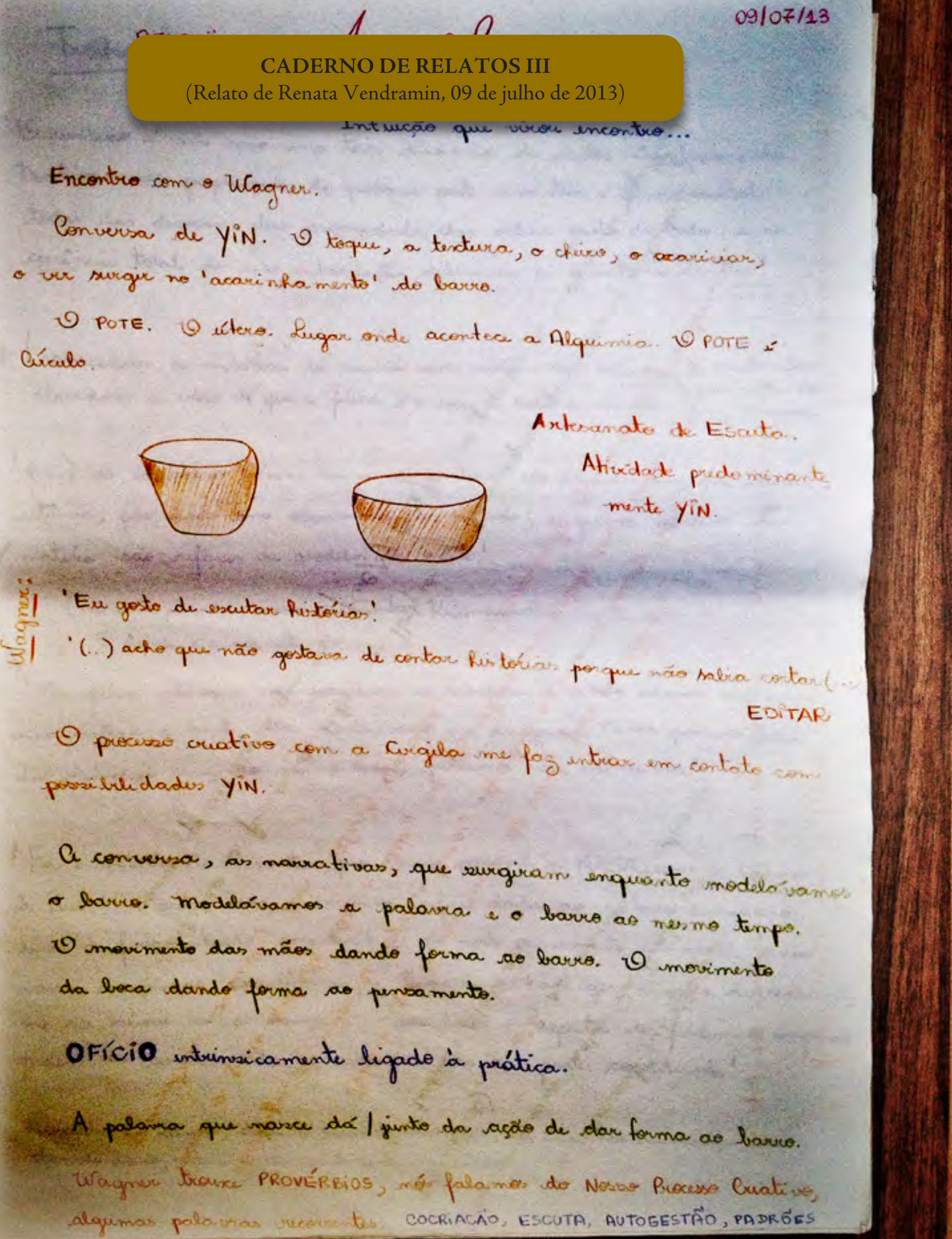

De uma intuição nasceu a possibilidade do encontro. Da intuição até marcarmos o dia do encontro passou bastante tempo, e neste tempo passaram nos nossos corposvozes julgamentos, dúvidas, questionamentos: AONDE ISSO VAI NOS LEVAR?

Não sabíamos (e não era a hora de fazer essa pergunta)... Vivemos, respiramos e deixamos fluir a nossa intuição e criatividade em ações criativas. 


$$
\begin{aligned}
& \text { lambuzar as măes de água + terra, afundar a mä́s ne varre, dare }
\end{aligned}
$$

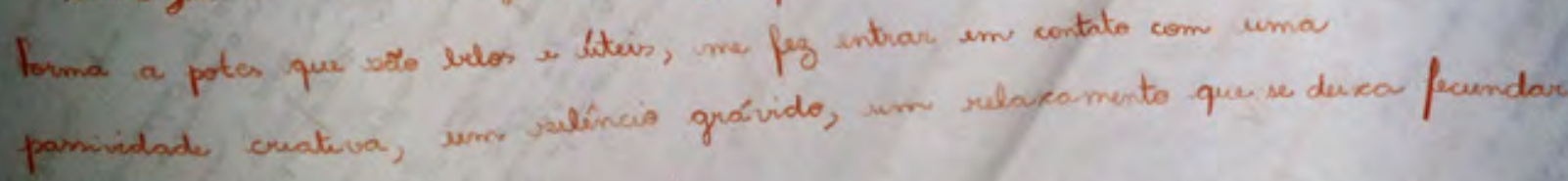

$$
\begin{aligned}
& \text { as contuídes e pormas de A Recixima llistúa gemham espace para severn gestados... }
\end{aligned}
$$

Assim íamos exercitando nossa presença $\mathbb{Y} \mathfrak{Q} \mathbb{N}$, ganhando confiança para manifestá-la. Dando-nos tempo e dando-nos espaço para encarná-la durante o sistemaprocesso.

AONDE ISSO VAI NOS LEVAR? é uma pergunta coerente e relevante de ser feita em determinados momentos do caminho. No entanto, se mal colocada, fora de hora ou com o tom equivocado, ela é capaz de abortar sementes criativas, delicadas, que poderiam florescer em finas e exuberantes flores.

$$
\text { E }
$$

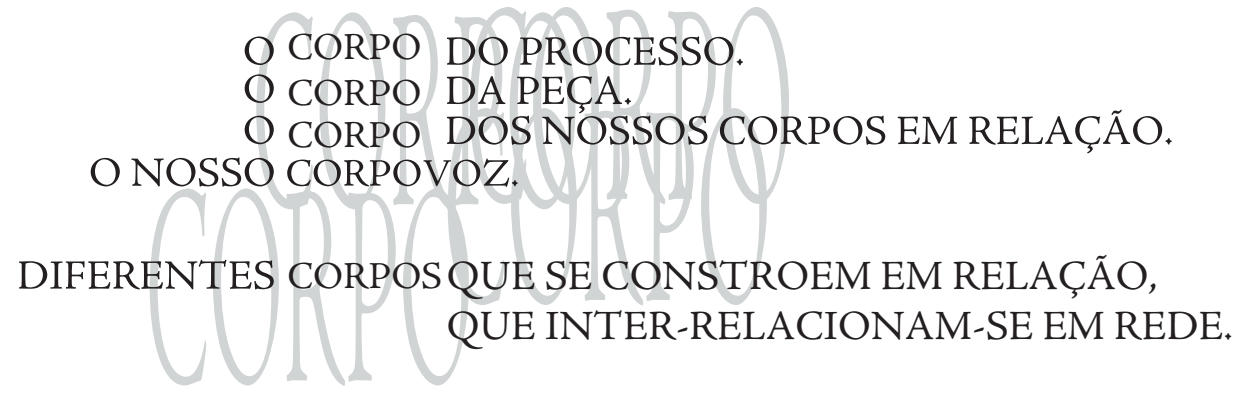

\section{O Corpo da Palaura}

(texto escrito por Renata Vendramin durante o sistemaprocesso)

Palauras são como corpos de matéria mais sutil, por isso não é possível vê-las.

Ao serem bem pronunciadas é possível sentir a sua presença corporificada.

Se nós, seres humanos, temos sete corpos de mesma matéria, variando de densidade, sendo que o mais denso e visivel ao aparelho da visão é o corpo físico, poderíamos dizer, criando uma analogia, que o corpo mais denso da palaura é mais sutil que o nosso e percebemos sua presença de outra maneira.

Às vezes uma palaura vem carregada de tanta coisa, como se tivesse muito lixo, muitas formas-pensamento no seu campo áurico, nos seus corpos. Apresenta-se uma necessidade, como diz o poeta Manoel de Barros, de escovar a palaura, de ir além de tudo que projetamos nela ao longo do tempo e voltar ao sentido de origem, à necessidade que fez com que aquela palaura fosse criada, que fez com que um conceito fosse transformado em verbo.

Palauras constroem e destroem mundos e vidas.

O verbo do criador fez nascer a vida. 
Nessa conversa sobre corpovoz, é imprescindível falar sobre O CORPO DA P A L A V R A, a maneira que modelamos palavras, sopros de sentidos, a necessidade que faz com que uma palavra seja escolhida, usada, criada ou recriada.

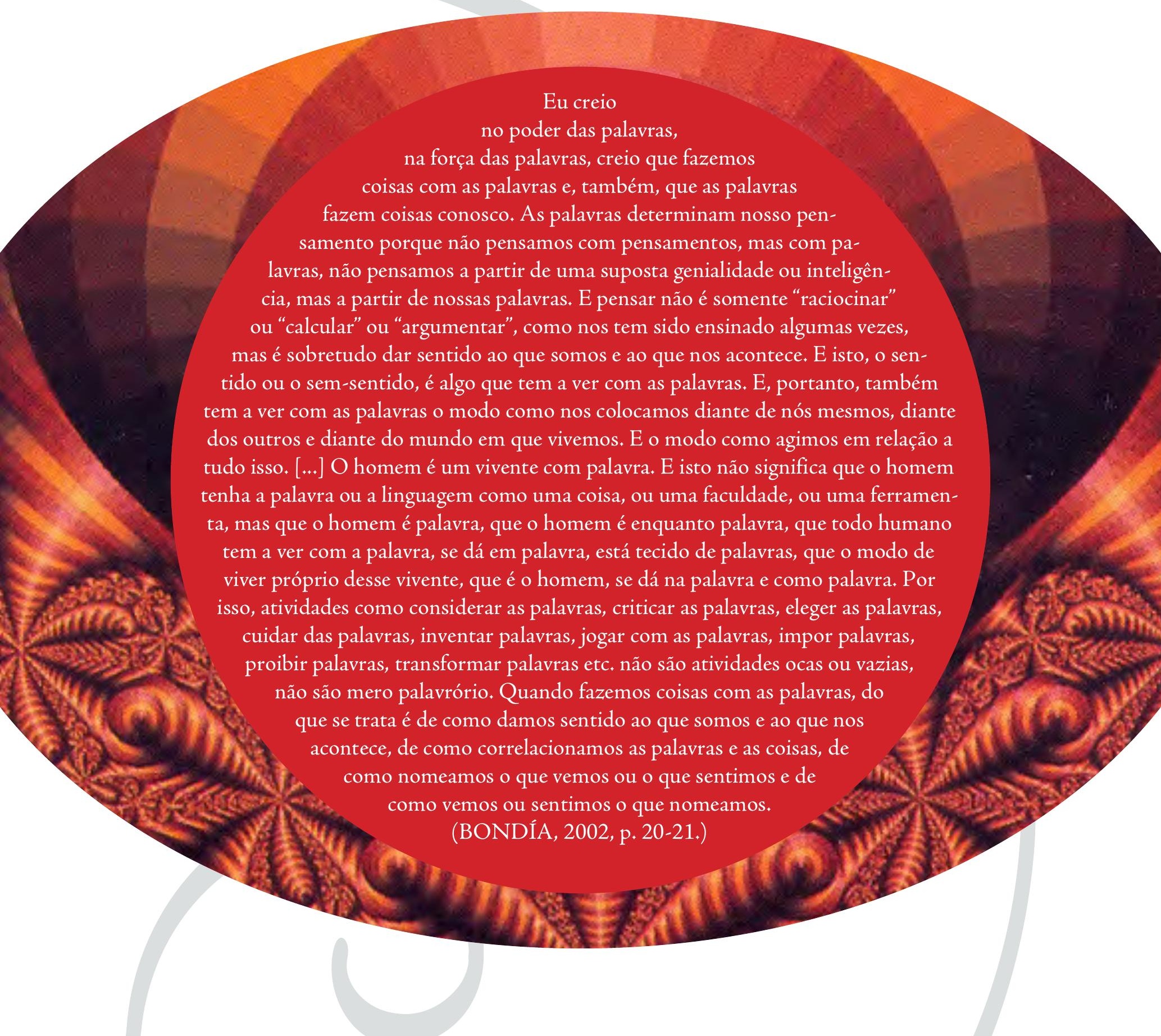

Jorge Larrosa Bondía em sua voz dialoga com o pensamento da tradição oral guarani. Vozes que ressoam profundamente em nosso sistemaprocesso.

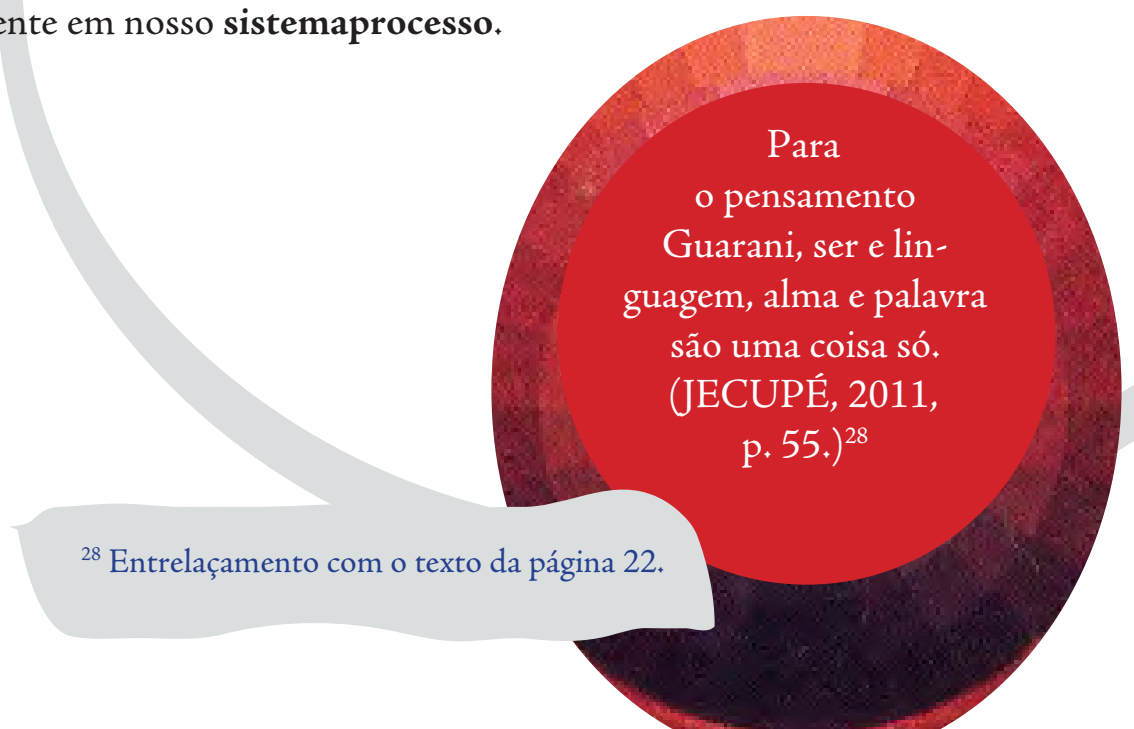


Os conceitos que nascem e renascem neste sistemaprocesso são sentidos e semsentidos modelados em palavra. Por vezes nomeamos algo para conseguir chegar mais próximas de determinada experiência (assim parece mais fácil criar uma relação); outras vezes a experiência vivida transborda em algum novo conceito que sintetiza os sentidos experienciados, mas não os esgota. Os conceitos, o corpo da palavra, assim como nossos corposvozes, não estão feitos, formatados, prontos e mortos. Eles pulsam. São sistemas em contínuo fluxo e mudança. Em processo de nascimento, morte e renascimento de sentidos. Como todo corpo, tem coração. OS CONCEITOS TÊM CoRaÇãO. Têm intestinos. Têm pâncreas. Têm ânus. $\mathrm{O}$ coração desse corpo, em relação a todos os demais órgãos, pulsa sentidos. Se deixar de pulsar, a palavra morre, o conceito morre... E muitas vezes é necessário que morra mesmo.

Os conceitos neste sistemaprocesso também são corpos conectivos, membranas vibráteis, corpos de entrelaçamento em constante cocriação. Nos muitos relatos transcritos, nos outros tantos que estão em silêncio nos cadernos, as palavras usadas vão modificando-se, maturando-se, contradizendo-se... Muitas escolhas de palavras usadas nos relatos seriam refeitas se fosse fazê-los agora no momento presente. Outros corpospalavras seriam colocados em relação. A escolha e o uso das palavras também criam as geografias do nosso sistemaprocesso. E esse fluxo contínuo de mudanças só acontece quando estamos em movimento, em experiência, em relação... Agora, enquanto escrevovivodouforma a este texto, continuo modelando e remodelando palavras, conceitos, sentidos...

Eu tinha vontade de fazer como os dois homens que vi sentados na terra escovando osso. No começo achei que aqueles homens não batiam bem. Porque ficavam sentados na terra o dia inteiro escovando osso. Depois aprendi que aqueles homens eram arqueólogos. Eque eles faziam o serviço de escovar osso por amor. Eque eles queriam encontrar nos ossos vestígios de antigas civilizações que estariam enterrados por séculos naquele chão. Logo pensei de escovar palauras. Porque eu havia lido em algum lugar que as palauras eram conchas de clamores antigos. Eu queria ir atrás dos clamores antigos que estariam guardados dentro das palauras. Eu já sabia também que as palauras possuem no corpo muitas oralidades remontadas e muitas significâncias remontadas. Eu queria então escovar as palauras para escutar o primeiro esgar de cada uma. Para escutar os primeiros sons, mesmo que ainda bígrafos. Comecei a fazer isso sentado em minha escrivaninha. Passava horas inteiras, dias inteiros fechado no quarto, trancado, a escovar palavras. Logo a turma perguntou: o que eu fazia o dia inteiro trancado naquele quarto? Eu respondi a eles, meio entressonhado, que eu estava escovando palauras. Eles acharam que eu não batia bem. Então eu joguei a escova fora. ("Escova". In: BARROS, 2010, p. 15.) 


\section{ACHEGADADE ARTISTASCOCRIADORAS}

O músico Alencar foi o primeiro a chegar ao nosso espaçotempo de cocriação. Com ele, tivemos o desafio e a oportunidade de compartilhar a nossa pesquisaexperiência e de integrá-lo ao sistemaprocesso. Além de integrá- lo aos movimentos que já realizávamos Janaína e eu, interessava-nos abrir espaçotempo para que ele propusesse práticas musicaisvocais a partir do seu conhecimento e repertório de músico e professor de música. A intenção era, na relação, descobrirmos juntos, $\mathrm{R}$ E S P I R A N D O E EXPERIMENTANDO, o que poderia ser trazido e como poderíamos integrar as propostas dele ao trabalho corpovoz que vínhamos realizando. Além disso, estávamos muito felizes de ter um músico para executar as músicas e sons que tanto ouvíamos no espaçotempo de cocriação. Esse era um desejo (e uma necessidade!) desde o começo.

\section{CADERNO DE RELATOS III}

(Relato de Renata Vendramin, 05 de setembro de 2013)

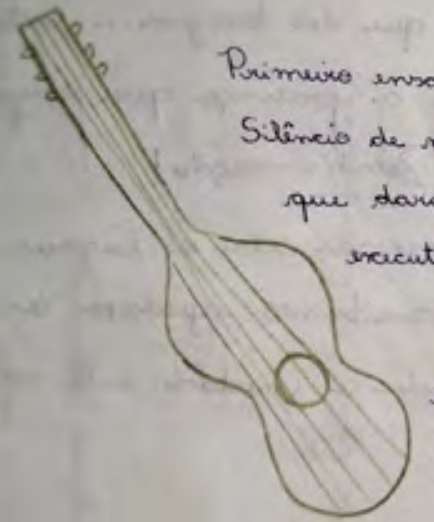

com o Alenct

Chegada da 3a puesur

unca na cena. Aluncar tem presença de ESCUTA.

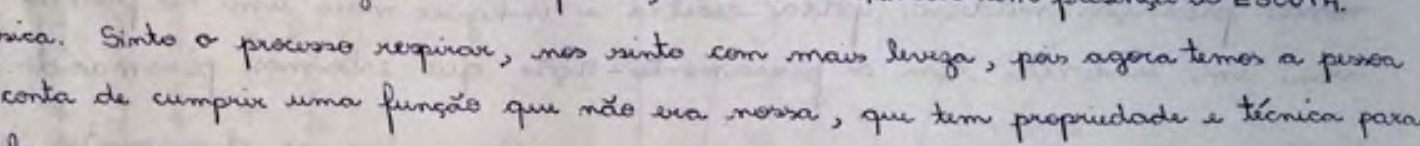

Começamos com nosiso truinamento gur conduzue aloumas uscalas socal is integrames a prusenfa do Alincax pur siolos. Uma nova pusenga faz com que a treinamento ne recrie e que seu valor seja afirmado.

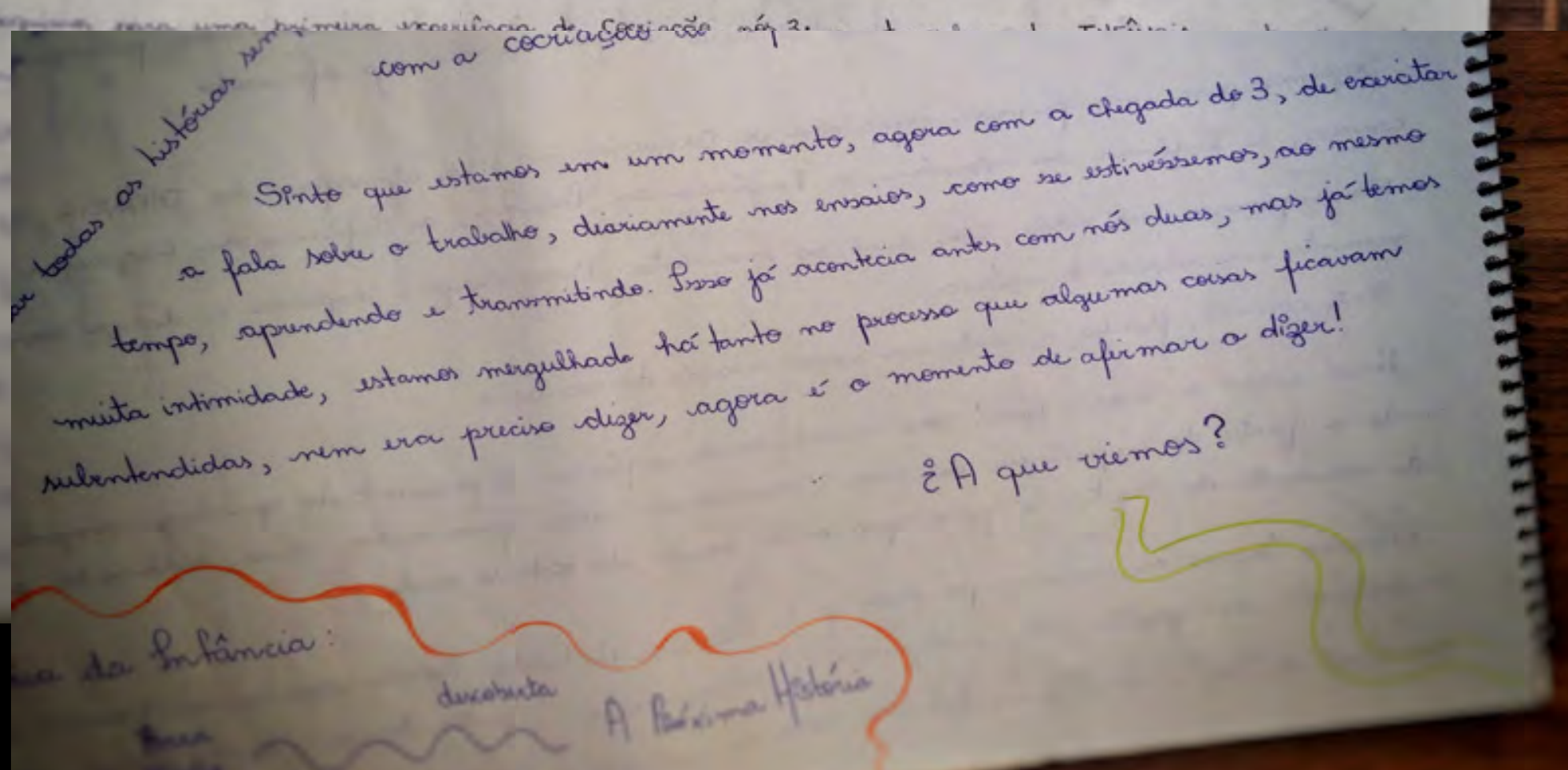


Essa terceira presença, que não estava desde o começo, que veio para se integrar, para se relacionar e para expandir o nosso sistemaprocesso, foi, ao mesmo tempo, desafiadora e fecundante. Desafiadora, pois Janaína e eu necessitávamos compartilhar pensamentospráticasconceitos que vínhamos maturandomodelando e que ainda estavam em processo de definição (alguns muito pouco palpáveis) com alguém que não conhecia nada do que havíamos experienciado até então e que chegava para cocriar conosco ${ }^{29}$. Fecundante, pois Alencar trouxe o seu fluxo e ritmo criativos para o nosso espaçotempo de cocriação. Uma nova e outra vozpresença para alimentar e inspirar o sistemaprocesso, e isso, para nós que vivíamos há um bom tempo uma relação a duas, foi extremamente saudável e prazeroso. Um outro terreno fértil para manifestar sua criatividade.

Nossa intenção, de fato, era que desde o começo do sistemaprocesso já tivéssemos com a gente todas as pessoas, ou pelo menos a maioria, que iriam participar da cocriação da peça: músico(s), figurinista, iluminador... enfim, quem tivesse que estar, para que juntas cocriássemos a experiência de gestar os pensamentospráticasconceitos desse sistemaprocesso. Isso para dar-nos tempo e espaço juntas, na experiência diária. Para aprofundar e fortalecer relações. No entanto, não foi possível por questões financeiras e de outras naturezas.

Integramos Alencar nas práticas corpovoz, lidando com todas as limitações que tínhamos. Alencar já havia trabalhado com outros grupos de teatro, feito práticas corporais, mas não tinha, naquele momento, uma disciplina de prática corporal constante, também não tinha quilometragem de trabalhos corpovoz direcionados para a criação teatral. Além disso, havia também uma certa timidez, que, a meu ver, era uma questão de ter mais experiência e relação com as propostas... Caminhamos juntos, em relação, respirando, e esse trabalho corpovoz, que acontecia para além das cenas teatrais, ressoava e ajudava na cocriação da peça propriamente dita.

O que contribuía muito era Alencar ter PRESENÇA DE ESCUTA, e sincronicamente ele se conectou à rede do nosso sistemaprocesso. Para nós, não era coerente apenas ter um músico exemplar e virtuoso; na verdade, era melhor ter um músico menos eficiente tecnicamente, contudo que tivesse presença de escuta. Alencar é habilidoso, talentoso e com presença de escuta.

Um tempo depois da chegada do Alencar, soprou um fluxovento no sistemaprocesso, e outras artistascriadoras também chegaram: o ator, que vinha colaborar com a percussão da peça, Gabriel Stippe, a cenógrafa, Lívia Loureiro, e o iluminador, Túlio Pezzoni. Além deles, já estávamos trabalhando com a figurinista, Áurea Teixeira (que chegou na mesma época do Alencar), a costureira Ilaise Rabello e a produtora do grupo Maria Tereza Urias. Cito o nome de todos por respeito e gratidão a cada uma dessas pessoas que passaram pelo nosso sistemaprocesso $\mathrm{e}$ receberam e doaram inspirações e ações criativas.

No entanto, intuo agora, olhando de fora, organizando a experiência vivida, que neste momento o SiSTeMa NERVOSO Da PEÇA começou a entrar em movimentos caóticos e desestabilizadores demais. A intenção, como já disse, era que essas pessoas todas já estivessem com a gente desde muito antes, acompanhando inclusive as nossas práticas para além dos resultados das cenas teatrais, para também encarnarem a consciência sistêmica. Não era coerente qualquer uma dessas pessoas chegar ao sistemaprocesso e fazer "a sua parte do trabalho do jeito que sabe fazer ou sempre fez". Primeiro porque numa encarnação sistêmica não existem partes...

Lidamos também com a situação de que as pessoas chegaram quase de uma vez só e não tinham disponibilidade para estar com a gente com frequência (a gente também não podia pagar por isso), portanto era muito difícil integrá-las ao sistemaprocesso. Afinal, não seriam com duas conversas ou com uma palestra ${ }^{\text {SOBRE }}$ o sistemaprocesso que iríamos conseguir compartilhar a nossa pesquisaexperiência.

É PRECISO DAR-SE

E DAR-SE
$\mathrm{E}$
S
A

P Ç

TEMPO

$\mathrm{O}$ 
Além disso, por esta época, havíamos definido o dia da estreia da peça, para janeiro de 2014, e da abertura de processo, para dezembro de 2013. Então começamos a lidar com um tempo de estreia. RERCEMAM D GONTEXTO DUE COCRIAMOS PARA TOS MESMOS! E mais um detalhe, a atriz Janaína Silva estava grávida, em dois processos criativos intensos simultaneamente.
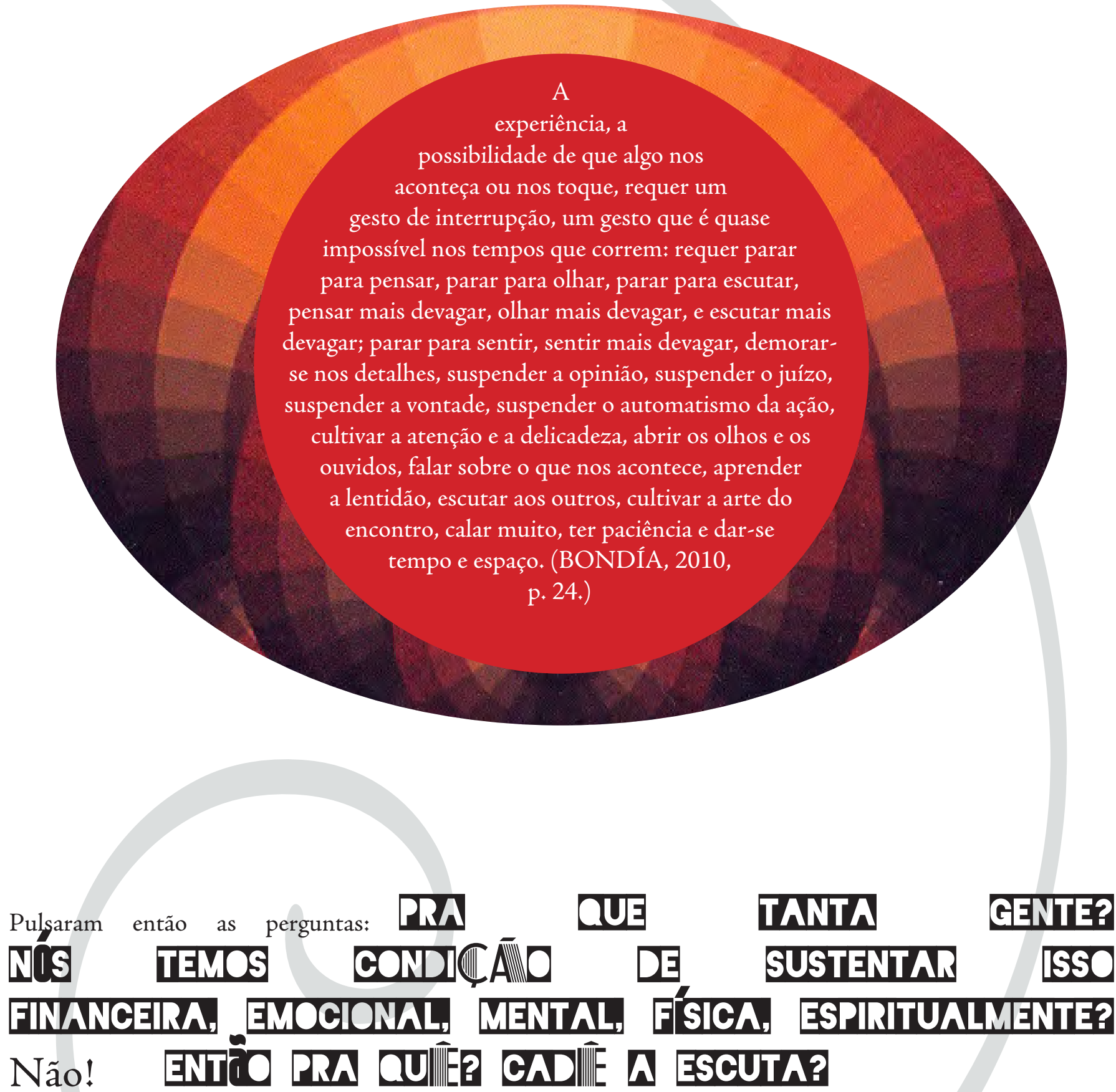
Eu sentia que os desejos da mente (e não dos corpos todos) estavam grandes demais para o corposistemaprocesso que tínhamos. Porém, como o trabalho era de cocriação, a menos que a proposta fosse absurdamente esdrúxula, a gente experimentava: os desejos, as intuições, as inspirações, as propostas que surgiam.

\section{ACREDITO QUE COMEÇAMOS A COCRIAÇÃO E DEIXAMOS DE}
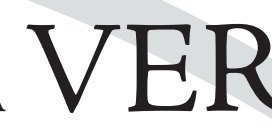

O espaçotempo para as nossas práticas corpovoz foi ficando cada vez mais reduzido, pois a urgência de fazerer, rEsOlVEr, SoLuCioNaR começou a prevalecer. Tínhamos uma data de estreia, tínhamos que produzir a luz, o figurino, o cenário... E o tempo reduzido que tínhamos para as nossas práticas começou a ser saturado por má vontade, preguiça, dúvida, se aquilo era realmente necessário, se não era perda de tempo... Às vezes uma fala ou outra revelava explicitamente isso, mas na maioria das vezes era a energia da resistência que se manifestava no espaçotempo de cocriação. O trabalho antes num...

\section{movimentofluxocriativo}

... começou a ficar árduo, dificultoso, cheio de sacrifícios para cumprir demandas, prazos, desejos impostos por um...
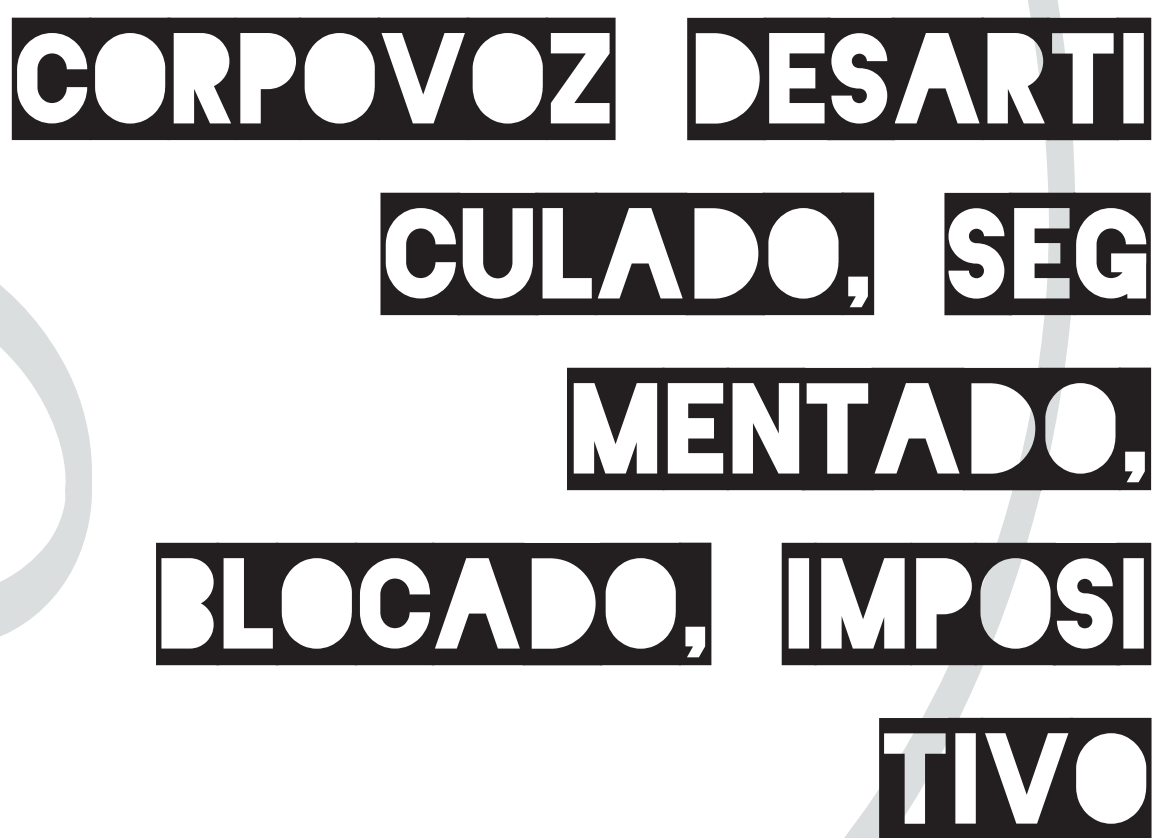

O nosso sistemaprocesso começou a entrar em colapso. Nosso trabalho diário de equilíbrio dinâmico das energias $\mathbb{W}$ e YANG desintegrou-se. Nossa experiência de dar-se tempo e dar-se espaço foi para o espaço sideral. Começamos a lidar com um tempo de produção, exigências, expansão... 

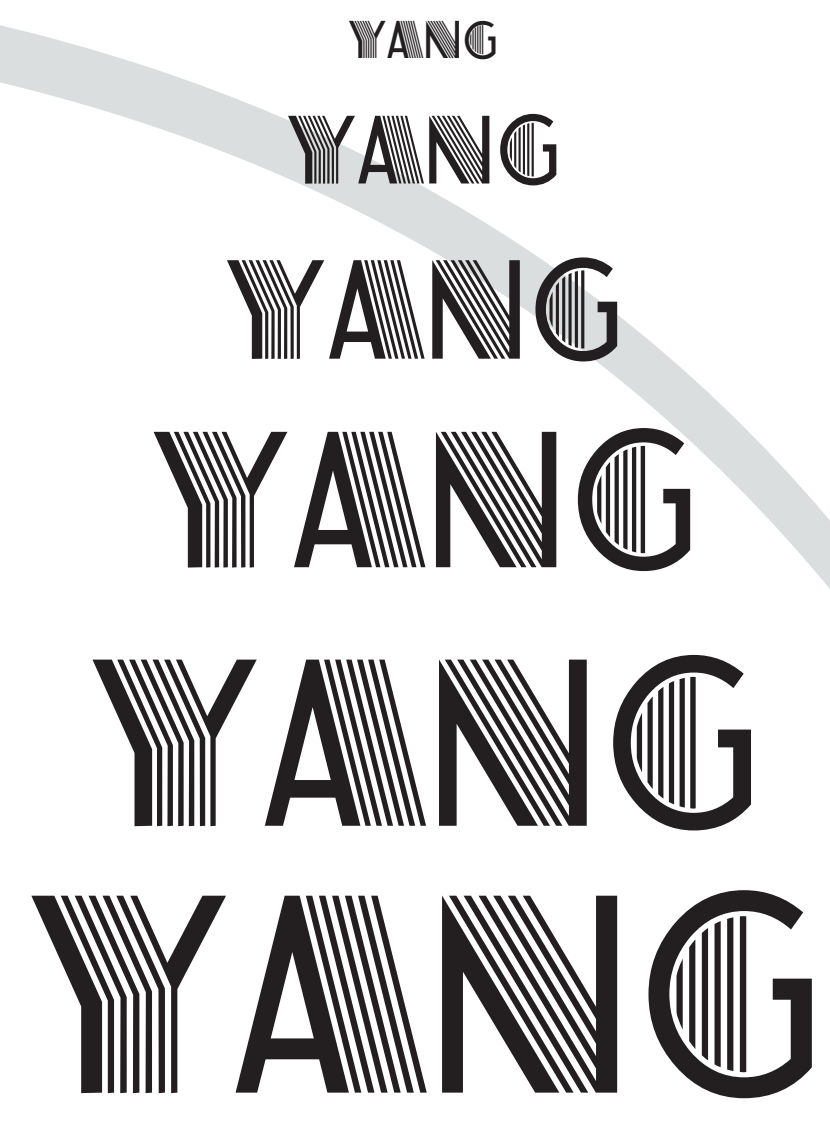

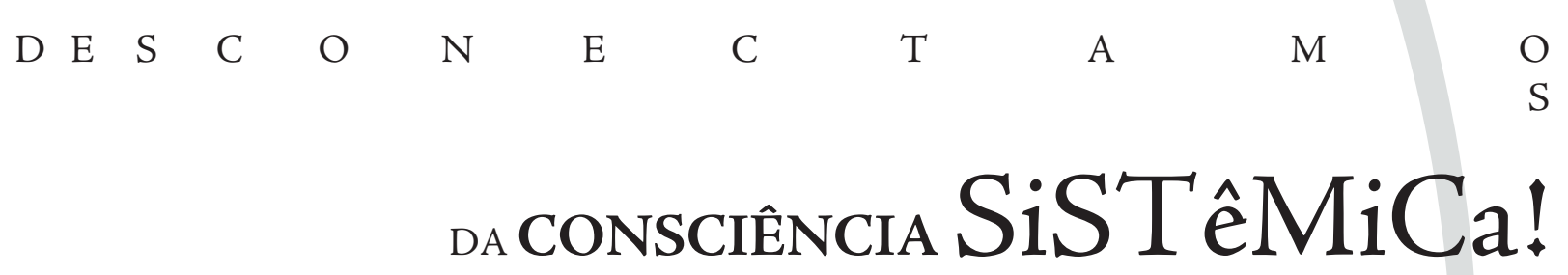

É esperado que, quando se aproxima uma estreia, uma abertura de processo, o equilíbrio ỸaN e YANG varie ciclicamente, que de fato tenhamos urgência em realizar determinadas coisas; mas ainda assim, e principalmente dentro do contexto em que vivíamos, da qualidade de vivência que vínhamos cocriando, era nítido que alguma coisa havia se desconectado.

$\mathrm{Eu}$, apesar de perceber e intuir que alguma coisa estava acontecendo, de começar a sentir-me oprimida pelo processo, não soube como agir. Não tinha maturidade para isso naquele momento. Acredito, agora, organizando a experiência, que precisava manifestar-me mais YANG naquele momento. Mas não quis ser impositiva... Nada é totalmente $\mathbb{Y}$ [N ou YANG, um aprendizado fino de equilíbrio dinâmico das energias.

É importante deixar claro que todos nós que éramos o sistemaprocesso naquele momento estávamos cheios de boas intenções, querendo fazer o melhor, colocando-nos disponíveis para o melhor. Contudo acabamos reproduzindo padrões trazidos de outros lugares, de outros processos, acionando a chave do "vou fazer o que eu sei ou o que eu seiimagino que funciona" (a partir de outro padrão pré-estabelecido), em vez de colocar-se em experiência para cocriar, perceber, modelar o padrão que diz respeito a essa pesquisaexperiência. Nós, que lidávamos com a temática também dos PADRÕES na peça, caímos em diversos equívocos ao lidar com nossos padrões de pensamentoação pessoais, em relação com outras pessoas.

Nesse movimento caótico do sistema nervoso da peça, cumprimos as demandas e prazos que nos colocamos e chegamos à abertura de processo realizada nos dias 30 de novembro e 01 de dezembro de 2013, na sede da produtora de cinema e vídeo ACERE, que era a residência artística do AIVU até então. 


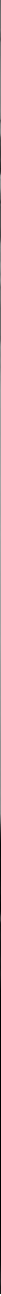

Figura 04. Abertura de processo da peça, dezembro de 2013. Foto: Tide Gugliano.
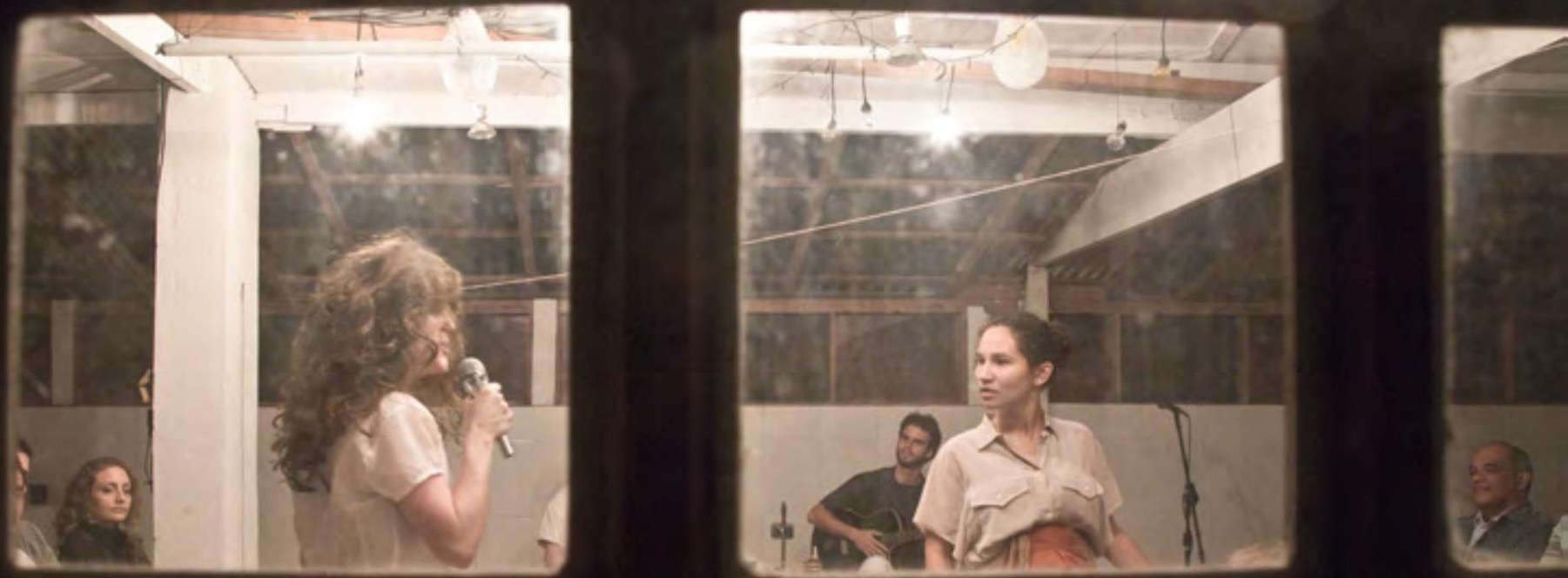

ather

Figura 05. Abertura de processo da peça, dezembro de 2013. Foto: Tide Gugliano. 


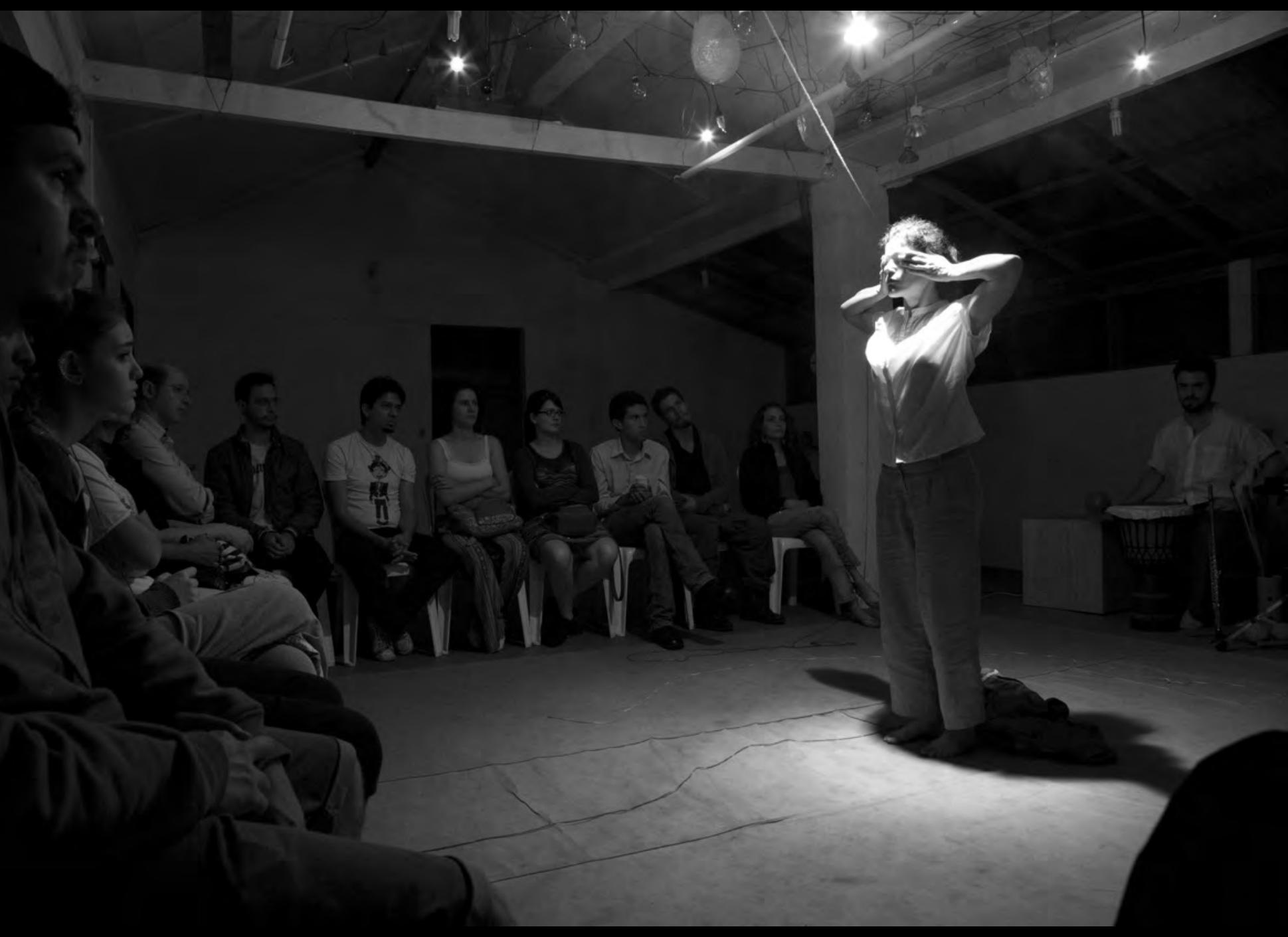

Figura 06. Abertura de processo da peça, dezembro de 2013. Foto: Tide Gugliano.

Mesmo com o sopro deste fluxovento que apareceu nos últimos tempos no sistemaprocesso, mesmo com a correria opressora dos últimos dias, mesmo com a sensação interna de querer reestabelecer uma conexão que havia se perdido, ainda sim fiquei satisfeita com a experiência dos dois dias de abertura de processo em fins de 2013. O encontro com o(s) outro(s) renovou minha energia e meu ânimo para seguir trabalhando na peça, fazer as modificações necessárias (percebendo alguns equívocos), para a estreia que estava prevista em janeiro de 2014. Não tinha ideia do que viria pela frente. 


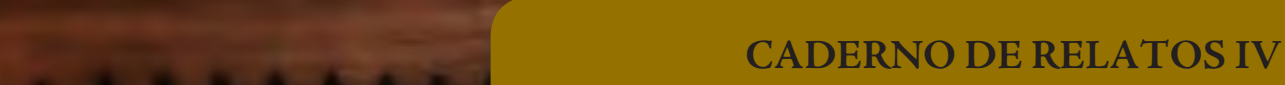

IIIIIII .

\section{1- dia ABERTURA JE PROCESSO mo morro}

Estou muito feliz, de coracäo e mente tranquilos. Sdewas, imagens, reflexcóes, proposicós passam por mim s/ ansiedades Duncando assentar a experiência pl ver o que fica...

Feliz com a Prusença de Escuta de todos nós, todos Yque fazmos parte deste processo.

Que excercício transformador é ouvir as vozess de perseass distintas, de muitos univeresos ₹s e viräss de mundo. Através da forma e conterido das falas percaler as padroes, as negasós, as questöes deles e minhas!

Muitas falas queundor que a dxamaturgia dè conta de 'amarrar' as células da peça, alguns parucem A = ter uma expectativa cortesiana, outros falam de uma dramaturgia circular, de repetigão, de símbolos/ nignos que podem se repetir... alguns signos que se anumeiam (como as roupas) e se perdem.

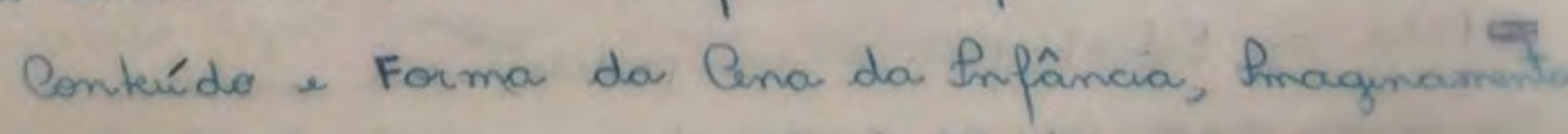
unânime: ali a perga acentece! filé!

Ia organizando a minha experiência desses dois dias no caderno de relatos, enquanto já intuía sugestôes de pequenas modificações na peça com base na ressonância nas pessoas. Só tenho relatos meus desses dias, pois até a prática do caderno coletivo se perdeu completamente nesse momento. 


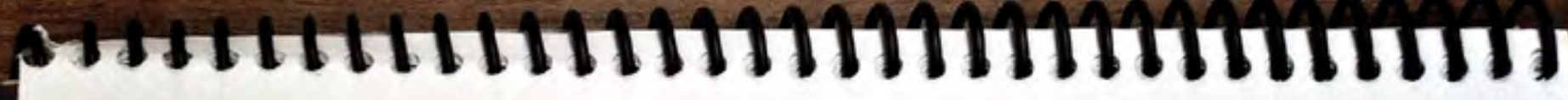 2- dia da alertura \\ $01 / 12 / 13$}

Não aquecemos juntos. No começo do espetáculo estávamos numa energia de 'enrosco', as rezes me senti seginha em cena. Foi lom. Foi a experiência do dia, daquele encontro es aceitar isso é um grande aprendizado pro grupo. Falar sobre a aquecimento e a concentraçãa.

Fuquei feliz de ouvir a voz de pexsoas como a flaise, que $\dot{n}$ trabalha ol criaça de dramaturgia, que embarcou na vragem que propusemos sem pensar em 'como eu faria', ou 'como eu gosto que seja'.

Eu estava enganada, não foi só a experiência do dia. Eu me senti sozinha em cena e foi a primeira vez que isso aconteceu na minha relação com a Janaína. Foi muito estranho e triste. Não sei se ela já tinha sentido alguma vez isso em relação a mim, mas eu sempre nos senti juntas (neste e nos outros trabalhos do grupo), confiando e bancando as escolhas que havíamos feito... Mas naquele dia não. Na verdade, a questão não era somente daquele dia, eu estava ficando sozinha mesmo no espaçotempo de cocriação. 
Depois dos dois dias da abertura, sentamos para uma conversa coletiva. A ideia era que todos já tivéssemos assentado e refletido sobre a experiência individualmente e no papo coletivo sugeríssemos modificaçóes para decidirmos juntos os próximos passos, afinal, a estreia da peça estava prevista para janeiro de 2014, e a Janaína já estaria com 8 meses de gestação.

Eu cheguei com a proposta de retomada de nossas práticas corpovoz, de práticas que ancoravam e protegiam nosso espaçotempo de cocriação, que permitiam a gente...

DAR-SE

TEMPO

E DAR-SE

$\mathrm{E}$

S

$\mathrm{P}$

A

Ç

$\mathrm{O}$

... para que as manifestações criativas genuínas em relação encarnassem em nosso sistemaprocesso. A gente precisava voltar a viver, a pulsar um SistemaProcess O e parar de cumprir demandas criativas. Além disso, trouxe sugestões de pequenas modificações para serem feitas em algumas células e na estrutura da peça. Tudo precisaria ser experimentando, como sempre.

Para minha surpresa, havia uma energia de insatisfação muito grande, uma vontade de quase implodir a peça e começar de novo. Nada parecia fazer sentido, a maioria de nós queria tirar a Figura Mítica ${ }^{30}$ da peça, cortar muitas células, ou seja, fazer praticamente tudo de novo. Parece que o encontro com o outro na abertura de processo levou a maioria de nós para um lugar de ser aceito, de ser aceito como teatro, de atender as expectativas espetaculares das pessoas...

A partir daí, testamos algumas coisas em poucos ensaios que deixaram em mim sensaçóes muito opressoras, de escravização da minha criatividade. Cessaram o fluxo e o ritmo criativos, e entramos numa busca alucinada por soluções. Precisávamos ter uma peça teatral em um mês para estrear!
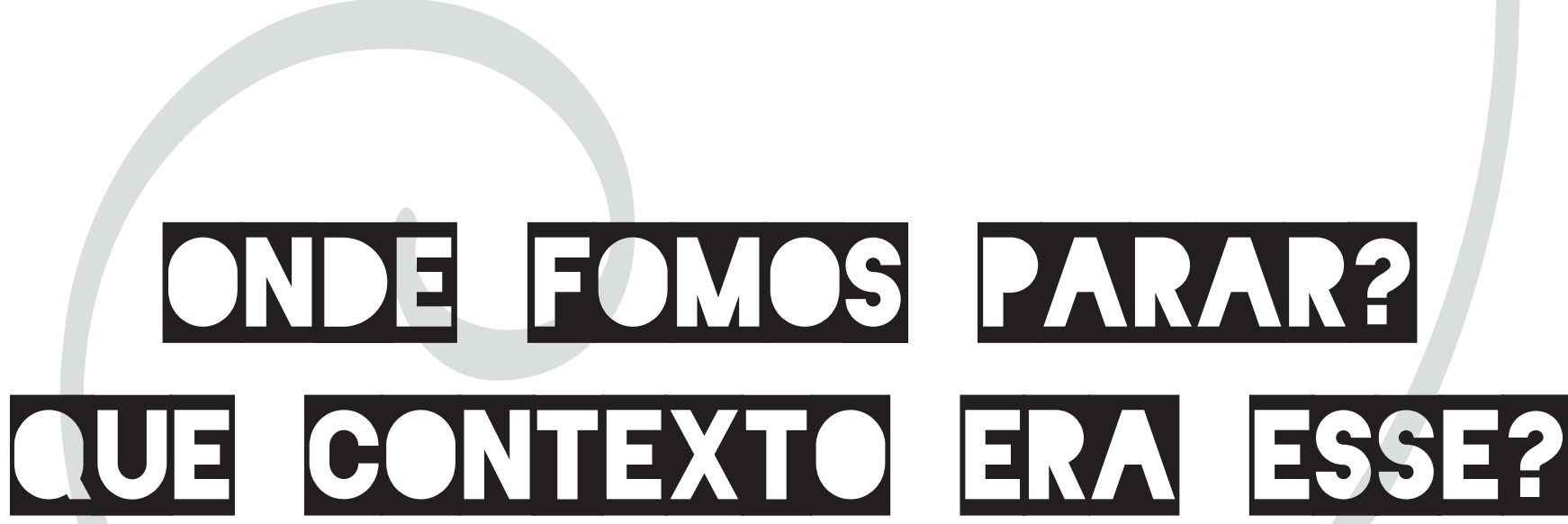

${ }^{30}$ Entrelaçamento com o texto da página 112. 
A sensação máxima de tristeza e desconforto eu senti em um dos ensaios realizados no Tendal da Lapa, o espaço onde iríamos estrear. Eu estava em cena, experimentando as propostas de modificações trazidas, e Janaína e mais dois parceiros cocriadores estavam de fora me dando "direções". Um deles então me disse para eu pensar no que a personagem tinha vivido antes para chegar até aquele momento dramático...

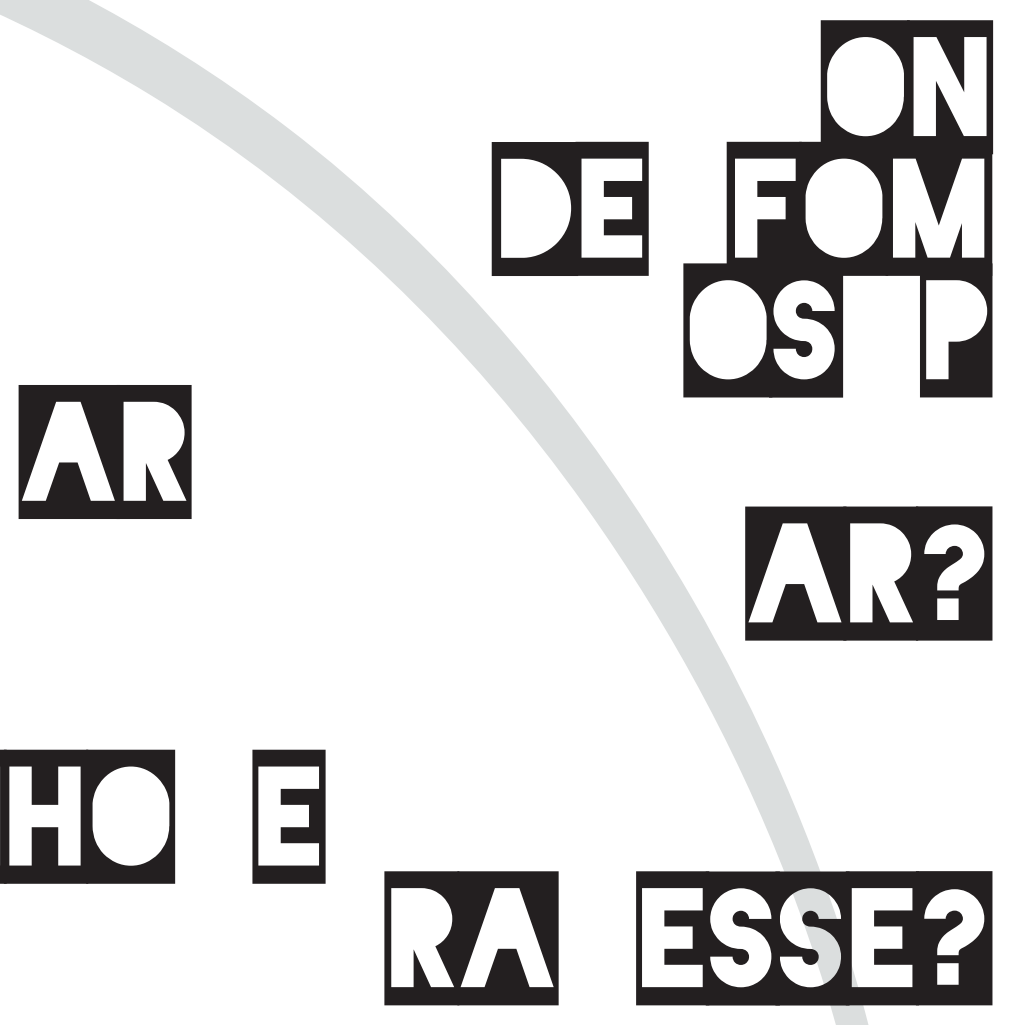

Não tive energia para dizer nada, nem sabia o que dizer. Estava muito fragilizada emocionalmente, pois, além de não perceber naquele momento o que precisava ser feitoditomanifestado, no mesmo dia, antes do ensaio, Janaína havia dito que sairia do AIvU depois da estreia da peça. Então eu coloquei a seguinte questão para o grupo:

Qual é o sentido de estrear uma peça, numa correria louca, com uma grávida de sete meses no meio de tudo isso, sendo que a peça não vai poder existir depois sem a presença da Janaína? Visto que a peça tem um caráter tão autoral, que não seria possível pensar em uma substituição.

Eu sugeri que a gente encerrasse o trabalho como estava, naquele momento. Não havia mais sentido continuar... Nem todos concordaram, muitas discussões aconteceram, que não vêm ao caso nesta narrativa, e então botamos um ponto final no primeiro ciclo do sistemaprocesso. Vale deixar claro aqui que esse PONTo FINAL não significou que tudo acabou; antes, foi o encerramento de um ciclo para começo de outro. A pesquisaexperiência seguia...

... um PONTo FINAL necessário para que renascessem os S E N T I D O S, O PONTO DE MUIIIIA CA. O...

...para voltarmos a darmo-nos tempo e espaço para que alguma experiência acontecesse.

Dar-se tempo e dar-se espaço é um movimento que começa dentro. O tempo e o espaço não existem fora, e não é ninguém ou algo que vai nos dar tempo e espaço. Somos nós que temos essa capacidade e esse dom de DARMO-NOS TEMPO

E $\quad$ E S 
Tudo isso aconteceu no começo de dezembro de 2013, na segunda quinzena do mês estava com uma viagem marcada para o interior do Paraná para visitar a família nas festas de final de ano. Ainda que, de um dia para o outro, não tivesse mais minha companheira de grupo (nem sabia se dava pra chamar de grupo o AIVU), não tivesse mais estreia de peça (nem sabia mais se tinha uma peça, depois de quase dois anos de trabalho até ali) e tivesse que dar conta dessa pesquisaexperiênciamestrado dali pra frente sem a presença da Janaína, decidi que não iria ficar pensando a respeito de nada.

$\begin{array}{llllllllll}\text { Decidi simplesmente } & R & E & S & P & I & R & A & R\end{array}$ deixar a experiência ASSENTAR-SE no meu corpovoz e abrir minha ESCUTA. O sistemaprocesso estava se movendo, estava dando-me a oportunidade de ${ }^{\mathrm{ENC}} \mathrm{ARNAR}$ tudo aquilo que achava que havia se perdido nos últimos tempos. DEI-ME TEMPO E E S P A Ç O confiei no sistemaprocesso, $e$ assim, aos poucos, comecei a entrar de novo no caminho da conexão sistêmica.

O único detalhe que me dava um alento em meio a esse turbilhão era que Alencar havia dito que continuaria comigo na cocriação da peça.

$\mathrm{R}$

E

S

$\mathrm{P}$

I

$\mathrm{R}$

$\mathrm{E}$

I

\section{ABRI A ESCUTA, DEIXANDO A EXPERIÊNCIA}

A
S
S
E
N
T
A
R
-
S
E 

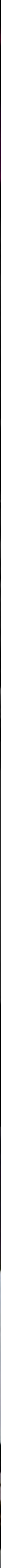
O PONTO dE MUTAÇÃO 


\section{R A N S I \& $\tilde{A} O$}

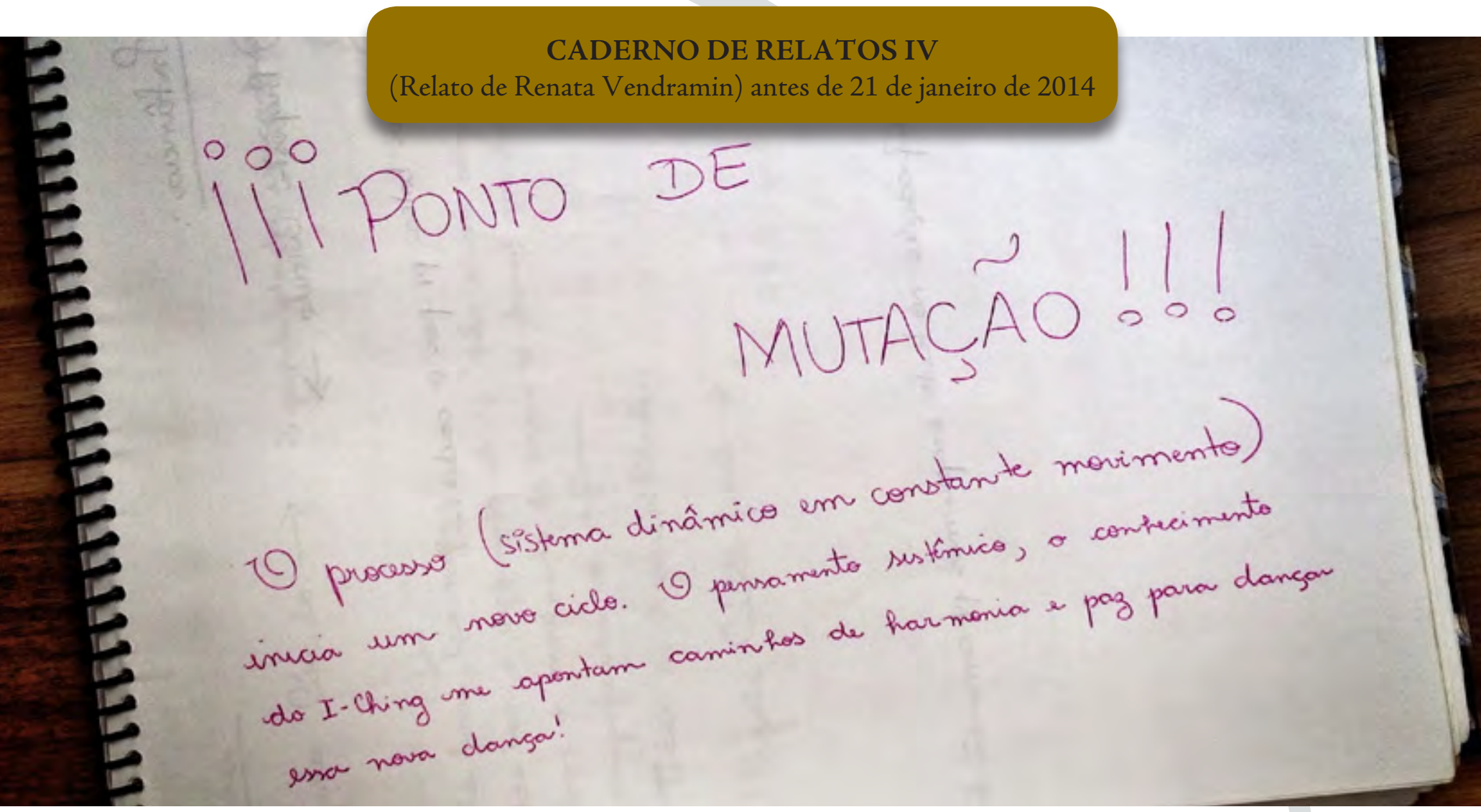

Quando todo o movimento de transformação aconteceu em dezembro de 2013, já tínhamos marcada uma viagem para a Colômbia em fevereiro de 2014, em que daríamos uma oficina, e eu compartilharia minha pesquisa de mestrado ${ }^{31}$. Por conta da gravidez da Janaína, alguns meses antes havia convidado Alencar para ir comigo no lugar dela, e ele havia aceitado. Tínhamos um compromisso firmado, e tudo acertado para a viagem.

Neste momento, mais do que nunca, o sistemaprocesso autorregulou-se, dando-nos a oportunidade de perceber o que seria daqui pra frente $c$ ação de caminhar...

A oportunidade da viagem, que foi criada alguns meses antes da abertura de processo, por meio da minha relação com o CEPECA ${ }^{32}$, era a única coisa concreta que tínhamos quando retornei das férias e retomamos os trabalhos. E foi a partir dessa oportunidade, desde a preparação da oficina até a sua realização, que começamos a descobrir a respiração comum daqui pra diante, voltamos a

$\begin{array}{lllllllll}\mathrm{R} & \mathrm{E} & \mathrm{S} & \mathrm{P} & \mathrm{I} & \mathrm{R} & \mathrm{A} & \mathrm{R} & \mathrm{UNNT}\end{array}$

agora Alencar, eu e o sistemaprocesso.

\footnotetext{
${ }^{31}$ A viagem estava relacionada ao projeto Inter-câmbios América Latina, idealizado pelo CEPECA (Centro de Pesquisa em Experimentação Cênica do Ator) e coordenado pelo Prof. Dr. Eduardo Tessari Coutinho. A oficina Teia Dramatúrgica: dramaturgia cênica tecida com palavra, música e dança foi realizada em Bogotá, na sede do grupo de teatro Varasanta, dos dias 25 a 28 de fevereiro de 2014.

${ }^{32}$ Centro de Pesquisa em Experimentação Cênica do Ator, do Departamento de Artes Cênicas, da Escola de Comunicação e Artes, da Universidade de São Paulo, coordenado pelo Prof. Dr. Armando Sérgio da Silva e pelo Prof. Dr. Eduardo Tessari Coutinho. Fiz parte desse grupo de pesquisa de 2007 a 2009 e voltei a frequentar em 2012. Durante todo o mestrado, foi um espaço de interlocução e desenvolvimento da investigação. Todos os integrantes do CEPECA são cocriadores desta pesquisaexperiência.
} 
Começamos a nos encontrar para preparar a oficina, pois a ideia era compartilharmos a condução. E quando chega esse momento de escolher pensamentospráticas para compartilhar, que sintetizem a experiência vivenciada, aprendemos muito. Parece que temos a oportunidade de ver a experiência com um olhar mais distanciado, pois precisamos dar esse zoom out (olhar a topografia da trajetória percorrida do alto) para fazer a escolha do que compartilhar. De maneira consciente e coerente, retomamos os movimentos do yoga ${ }^{33}$, integrados com os movimentos vocais, as práticas do Som nos/dos $\mathrm{Chacras}^{34}$, do Canto das Mutações ${ }^{35}$, do caderno de relatos ${ }^{36}$, e lançamos novamente as vozes de Capra, Brook e Fabião no espaçotempo de cocriação. Também sugeri integrar alguns exercícios que trabalhassem com ritmo, sob a condução do Alencar.

Nossos encontros para organizar a oficina eram práticos. A intenção era experimentar conosco e, ao mesmo tempo, reestabelecer o nosso fluxo, ritmo e disciplina de práticas. Trazíamos a proposta e fazíamos. Dessa maneira, fomos gestando experiência, relacionando-nos com a oficina que estávamos cocriando.

\section{MODELANDO O CORPO DA OFICINA.}

\section{ENCARNANDO A OFICINA.}

\section{Faixa $05^{37}$}

DVD 01 / Faixa 05

${ }^{33}$ Entrelaçamento com o texto da página 58.

${ }^{34}$ Entrelaçamento com o texto da página 68.

${ }^{35}$ Entrelaçamento com o texto da página 69.

${ }^{36}$ Entrelaçamento com o texto da página 30.

${ }^{37}$ Os vídeos que serão entrelaçados ao texto a partir de agora têm a intenção de compartilhar um pouco da atmosfera do trabalho realizado, sejam ensaios, oficina, ensaios abertos, compartilhar com cocriadores, relatos em vídeo. A edição foi realizada por mim mesma, e não visa mostrar os melhores momentos, o movimento mais bonito, a fala que está clara ou que deu certo, mas o processo de cocriação dos nossos encontros, a maneira como estabelecemos relação uns com os outros, o modo como fui cocriando minha falapensamento a partir das experiências vividas. Sendo assim, não me importei de deixar tempos mais longos de experimentação, de duração das práticas ou silêncios, para que pudesse transmitir minimamente ao leitorespectadorouvinte que vive essa experiência de leitura um pouco das texturas, das cores, dos tempos, da respiração dessa pequisaexperiência. 
CADERNO DE RELATOS IV

(Relato de Renata Vendramin, 25 de fevereiro de 2014)

Primer día del taller! Propósito

Estou em estado de graça, transbordando de alegría - gratidão. Chegamos a 23 pessoas na oficina.

Feliz por trazer na conduçäo um equilíbrio das energias YIN e YANE; filiz por ter tranquilidade na cocriagäo da experiência, percelendo o tempo de falar, a gte falar, ir construindo juntos, revelen do e compartishando o conhecimento as poucos.

Temos pessioas variadas: do teatro, da dança, da música, das artes visuais, da literatura,.. uma mustura, interrelaçáo de pontos de vista, uma rede!

a parceria com. Alencar está fluindo muito bem, temos afinidade, escuta, estarmos juntos.

Mamento fino da prática: Música Celestial, as vozes de todos: emessás luver das vogaus, depois dost chacras. Sugeri esse movimento na hora, seguindo minha intuiçäs...

SABEDURÍA INTUITIVA

94 


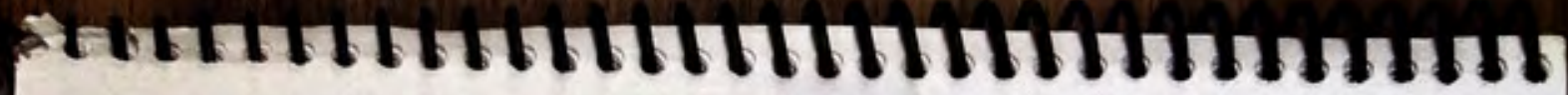

los cuerpos disponibles de los latinos-

AMERICANOS

Se ustabelecuu uma conexcion de coraçäo.

Sinto que me halito...

me sinto presente...

Mne sunto uma cidada do mundo...

me sinto conectada do lapra, as conhecimento

que sle se conecta...

Me sinto rede, me sinto sistema, me sinto parte, me sinto todo...

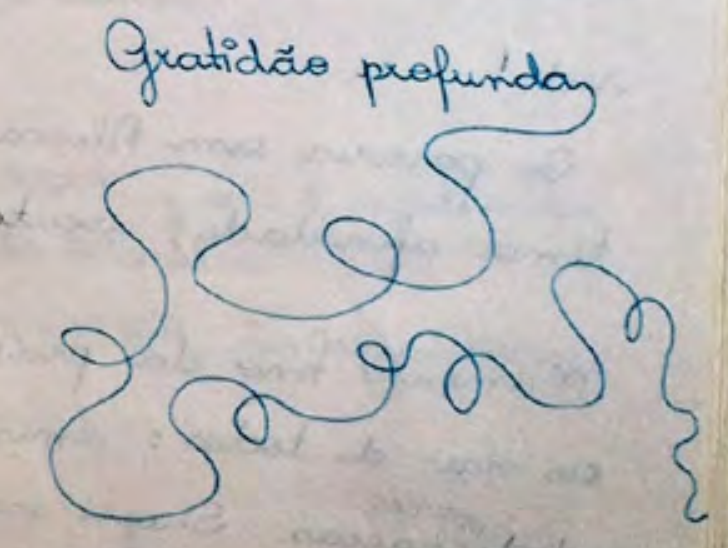

$\checkmark$ disconforto do coppo: rins e bexiga ustá se desfazendo.

Alguns dias antes de embarcar para a Colômbia, comecei a sentir um desconforto quando urinava, algo que nunca havia sentido no meu corpo. Meu sistemacorpovoz também estava se movendo, lidando com seus medos, tensões, angústias... eu segui respirando, liguei para o meu terapeuta ayurvédico, sob orientação dele comecei a comer castanhas e cebola crua todos os dias, e, durante a viagem, vivendo a experiência, o meu sistemacorpovoz também foi autorregulando-se.

Digo, com confiança, que esta oportunidade de realizar a oficina na Colômbia, em outro país, em outra língua, com pessoas com outros padróes culturais (pelo menos com diferentes nuances dos nossos) foi o primeiro movimento do segundo ciclo da pesquisaexperiência. A oficina, assim como toda a viagem, o encontro com artistas e grupos de teatro de lá, os encontros nas Universidades para compartilhar a pesquisa, renovaram a minha energia e a do sistemaprocesso. Eu não teria imaginado movimento mais coerente e oportuno para reiniciar essa dança. Durante este período a peça ficou descansando. 
Na volta da viagem, dediquei tempo à escrita de um texto que nasceu a partir da experiência vivida na oficina na Colômbia ${ }^{38}$. Em abril de 2014, Alencar e eu retomamos os ensaios da peça. Começamos por uma conversa em que lancei a seguinte pergunta:

\section{CADERNO DE RELATOS IV ${ }^{39}$}

(Relato de Renata Vendramin, 04 de abril de 2014)

apupujuamente do prépésito.

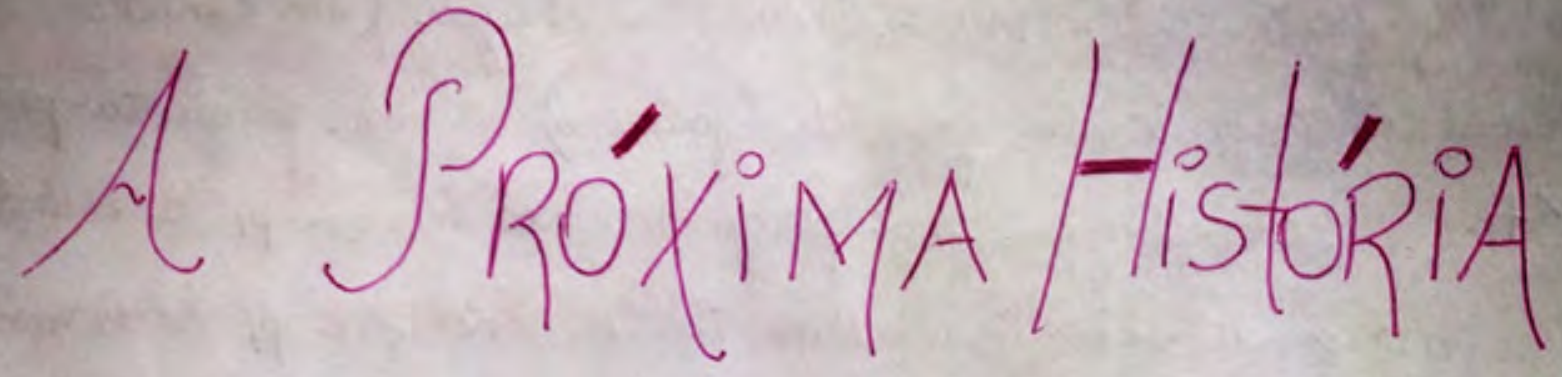

- (O) qui, de tuido que construímos até aqui, no espetáculo é essencial manter? Que diz respaito la uszência è à forsa do espetácule? Uma cena, uma pergunta, uma atmosfera, uma frase, uma palavia, um estado, um movimente, uma música, um silêncie...

\section{Figura Mitica, a Mais Velha Que a tempo,} Favetiva que a apresenta muselando

Novas geografias começariam a se delinear, mas alguns trajetos percorridos ainda faziam muito sentido. Era preciso saber discernir o que ficaria para trás e o que seguiríamos botando as mãos, o coração, o corpovoz, o espírito. Para isso, voltamos para o espaçotempo de cocriação.

\footnotetext{
${ }^{38}$ Esse texto resultou no artigo Serpenteando: relato de uma experiência de cocriação em fluxo e ritmo criativos, que foi enviado para ser publicado na revista PesquisAtor, especial Inter-câmbios América Latina, editada pelo CEPECA. Até o dia de entrega dessa dissertação, não foi divulgada a data em que esse número da revista estaria disponível. De todo modo, segue o site para consultas: http://www5.usp.br/tag/pesquisator/.

${ }^{39}$ Entrelaçamento com o texto da página 192.
} 


\section{RE NASCIMENTO}

Neste segundo ciclo teríamos menos dias de ensaios juntos, Alencar e eu, devido à disponibilidade da agenda de Alencar. Era uma condição do trabalho. Posto isto, lidamos com essa situação, aproveitando ao máximo o espaçotempo que tínhamos juntos, sem negligenciar e deixar de lado as práticas que ancoravam, protegiam e permitiam que a experiência encarnasse.

\section{PRÁTICAS QUE ANCORAM E PROTEGEM O TRABALHO, PERMITEM QUE ELE ${ }^{\mathrm{ENC}}$ ARNE.}

Alencar trazia-me o desafio de trabalhar o corpovoz de um músico, de trabalhar a presença de um músico na cena teatral, de descobrirmos outras possibilidades de pensamentosaçóes ao invés de:

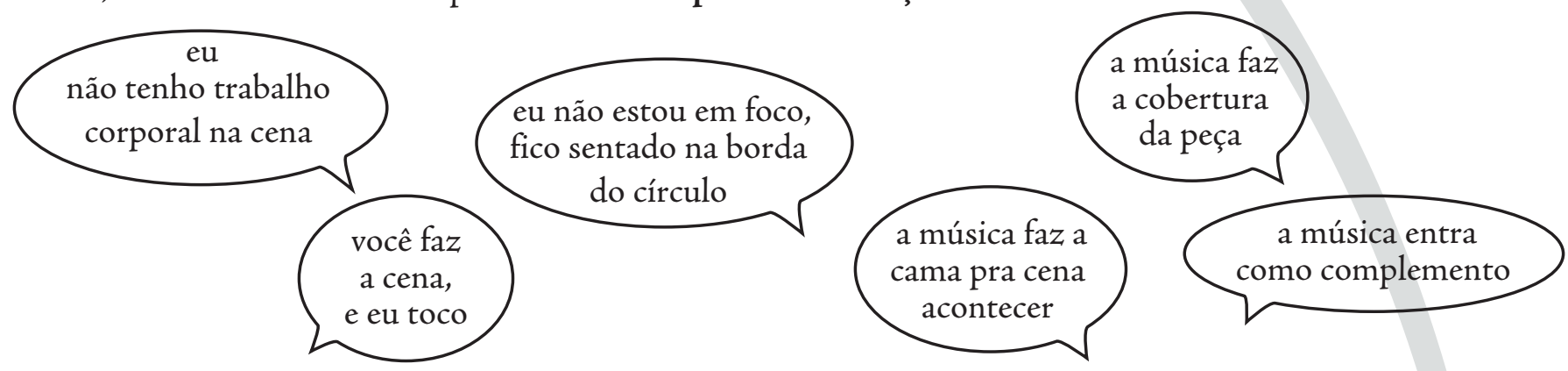

Ou tantos outros pensamentosações que, dentro do contexto de um sistemaprocesso que encarna a consciência sistêmica, seria incoerente. Somos uma rede de inter-relação e interdependência.

\section{COCRIAMOSJUNTOS, EM RELAÇÃO, A TODO MOMENTO.}

Seguimos trabalhando no fluxo da experiência vivida na Colômbia, a partir das práticas que escolhemos compartilhar lá. Tínhamos ensaios juntos, Alencar e eu, e também comecei a ensaiar sozinha, preservando e encarnando no espaçotempo de cocriação o trabalho com o corpovoz. Uma oportunidade para descobrir e alcançar camadas mais profundas da experiência de trabalhar $\mathrm{S}$ 。 $\mathrm{Z}$ I N H A EM coCRIAÇÃ O. Encarnar essa consciência de cocriação em cada ação rotineira, em cada respiração. Encarnar a consciência sistêmica.

No primeiro dia de ensaio prático, depois do retorno da viagem, escolhi habitar o espaçotempo de cocriação sozinha, sentia necessidade disso, queria simplesmente respirar... dar-me tempo e dar-me espaço para chorar, rir, gritar, dormir, meditar, ou o que desejasse... não queria ter a função de conduzir a prática naquele dia... queria escutar, sentir as saturações do espaçotempo de cocriação, sentir os sentidos e semsentidos que ainda pulsavam, sentir-me em relação ao novo contexto que habitava.

Os ensaios de 2014 foram retomados nas salas práticas do Departamento de Artes Cênicas da USP, pois, junto com todos os movimentos que aconteceram, também a parceria do AIVU com a produtora AcErE se findou, com gratidão, no começo de 2014. Ficamos sem uma residência artística fixa, sem o espaço que tínhamos para ensaiar.

Chegar até a sala de ensaio neste dia foi muito difícil, pois eu estava lidando ainda com a MORTE, muitas mortes (morte do sistemaprocesso como era, das relações que existiam, das condições que tínhamos antes como grupo, morte de como eu era em relação ao contexto que não existia mais)... imaginar o que seria daqui pra frente foi mais sofrido do que me colocar disponível no espaçotempo de cocriação para encarnar o que seria daqui pra frente. $\mathrm{O}$ antes foi mais difícil do que o momento presente. Cheguei à sala de ensaio, e ela estava iluminada com a luz do sol. Comecei, então, a alimentar-me dessa energia YANG, solar, para conseguir dar os próximos passos... 
CADERNO DE RELATOS IV

(Relato de Renata Vendramin, 25 de abril de 2014, coloquei 2011!)

Terra Galáctica Dermelha: 25/04/11

Rutemada dos envaios práticos do novo ciclo de A.P.H.

Sala 21, eu. Trabalho de me relacionar e memorigar o texto menina da Llua.

Feliz. Chegui na sala 21, que estava iluminada, arejado, me convidava a halitar este espaco do novo, vazio. É um novo espaço vazio, apesan de muitos elementos que vriamos até aqui vontinuarem no processo, mas a relaçäo entre eles e da gente (Alencar e eu) com eles será completamente nova.

Escolhi adentrar esse novo espago hoje sogin ha, estava precisando mesmo: escutar o siléncio, reconhecer as novar condiçóes do campo, perceber u afinar a uninina presenco neste campo como PESQVISATRIiz que conduz esta investigascio, que alimenta teoricamente a pesquisa e, fuinto y Alencar, thom alimento criativa. mente.

Comecui com a Yoga integrado of excercicios de voz,

aus, rolés, Ha ... escolhi encercicios mais vigorosos pl
(†) tambor)

98 
177

ativar essa energia de recomeço. Foi mais fácil udo halriti o espaço do que chegar até aqui.

Reencontra. com os textos, $\theta$ trabalho, cl a minha vez (que segue mudando e $\tilde{n}$ tenho encercitado todos os dias) foi muito prazeroso, gostoso, tudo faz sentido, $\vec{n}$ precisa de esforco, gastar energia pensando no que terei. Fluxo, Ritmo criativos, estäo sempre, continuamos mantundo-os c/ a Oficina, a excrita da desiertagãa ... agova é ATUAR na lena. tQue me inche de vitalidade e alegria, que í esseneral para a minha sauide!

No espaçorazio en me presentifico.

Inaugurado o Espago Vazio deste ciclo que se inicia, as forças que o habitam se apresentam. algumas covias morreram e seguimos $\theta$ curso...

Escuto o que ainda pulsa sentido.

Eu pulso sentido.

99 
A partir de hoje o tempo pi o registro no caderno será sagrado, nos ensaios individuais ou c/ Atencar, no final do ensaio. Tbm iniciei hoje o registro de falas no vídeo, olhando pra câmera. A palaura escrita e falada ressoam $\neq s$ formas e significados.

Reconhego que esses ensaios individuais säo essenciais. Sigo $q_{1}$ eles. $P \mid$ \& trabalho $c /$ os textos da Infância e da Fig. Mútica. Vou atrás de uma máreara.

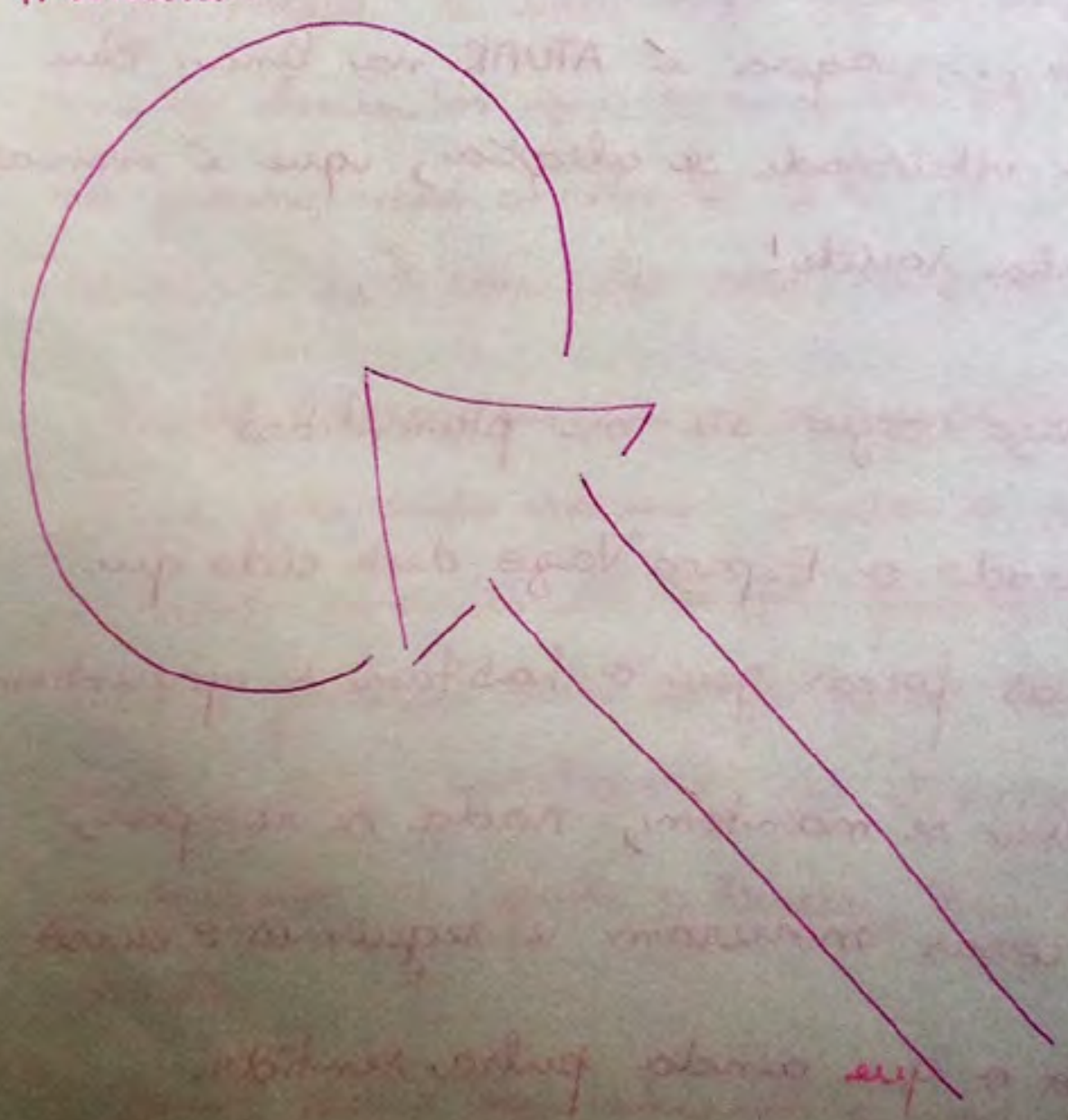$$
\text { Evoe'!!! }
$$

100 


\section{EscUTo o QUE aINda PUlsa SEnTIdo. EU PULSO SENTIDO.}

Faixa 06

DVD 01 / Faixa 06

Quando falo acima, no relato escrito, em habitar um novo espaço, isso diz respeito ao novo momento do sistemaprocesso, ao novo contexto, ao seu renascimento, considerando que, em um processo de renascimento ou reencarnação, trazemos conosco tudo aquilo que aprendemos, vivemos e experienciamos, todos os sentidos e semsentidos cocriados, mesmo que fiquem adormecidos, silenciados, em algum dos nossos corpos, disponíveis para serem incorporados quando necessário.

Quando falo de vazio, o vazio do espaçotempo de cocriação que experienciei neste primeiro dia de ensaio, refirome àquele vazio cheio de latências e saturações. No espaçotempo da sala 21, estava somente eu fisicamente, senti sim a solitude de habitar sozinha (sem a presença física de outras artistascocriadoras) a sala de ensaio. No entanto, toda a experiência já vivida, tudo aquilo que várias artistascocriadoras, que se conectaram ao nosso sistemaprocesso, trouxeram, assim como as vozes de pensadores e artistas trazidas nos materiais artísticos e teóricos, saturavam o espaçotempo de cocriação.

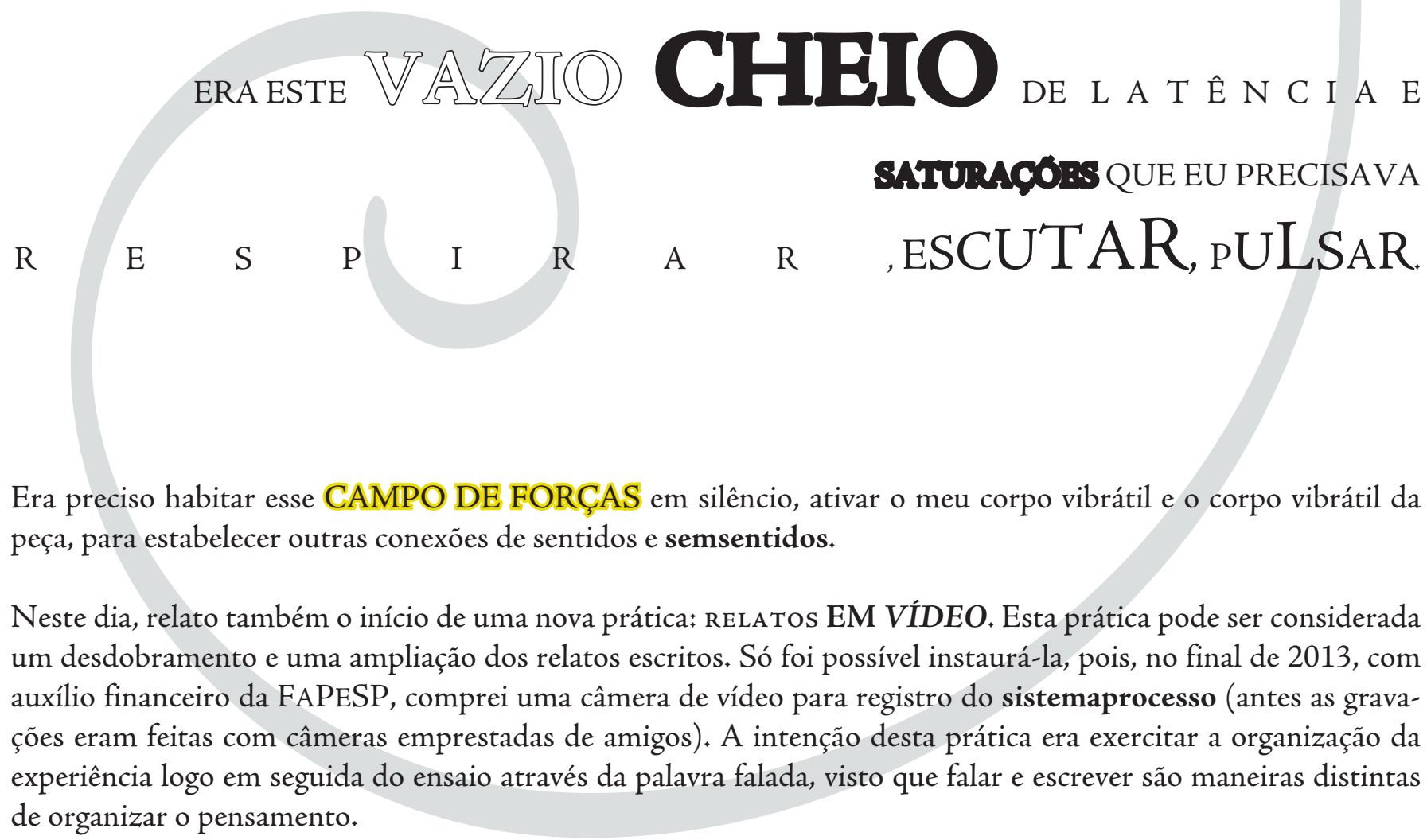


Para além do conteúdo articulado pela palavra falada, também me interessava registrar em vídeo a nossa presença, a nossa respiração, a qualidade da nossa energia, o ritmo e tom da nossa fala, de acordo com cada experiência vivi$\mathrm{da}$, deixando que nosso corpovoz organizasse e revelasse um pouco da experiência do ensaio. Como toda prática nova que encarna em um sistemaprocesso, temos de praticá-la para que ganhe sentido e gere sentidos.

A câmera pode intimidar, pode ativar o ego de maneira equivocada, pode deixar as pessoas mais tímidas, nervosas, incapazes de articular o pensamento de maneira fluida e livre, que era a nossa intenção. Nós praticamos!, como vocês poderão acompanhar nos próximos textos. Nos relatos do Alencar, normalmente eu fazia perguntas para ele falar um pouco a respeito, ou estabelecíamos mesmo um diálogo, com os dois em quadro. Eu tenho mais relatos feitos diretamente para a câmera, em que discorro livremente, articulando o fluxo de pensamentos e sensaçóes do dia. Gostaria de ter mais relatos do Alencar nesse fluxo individual, mas para isso precisávamos praticar mais o relato em vídeo, individual e coletivamente.

Di de reorganzar :

Reargarizarto corpo

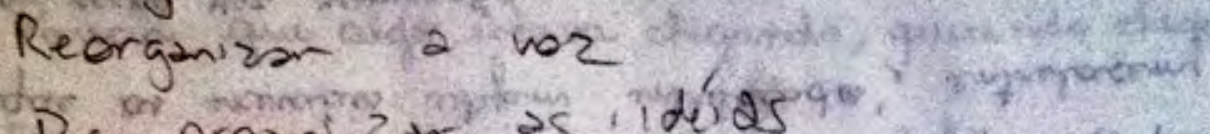
Re organizar as ide 25 igis:

Re arganizat os concertos ante-ing $\operatorname{Ling} x$

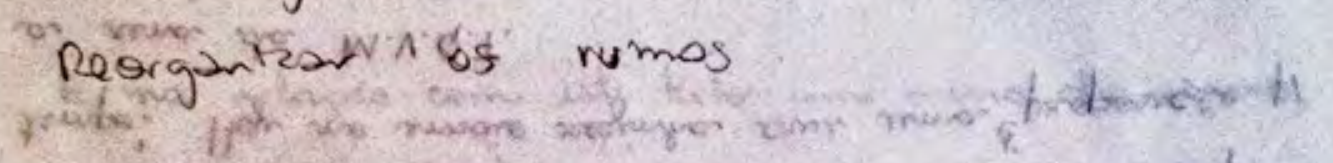

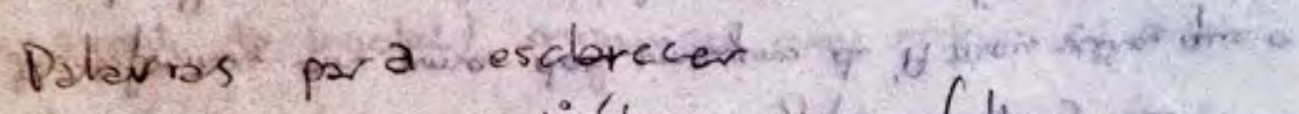

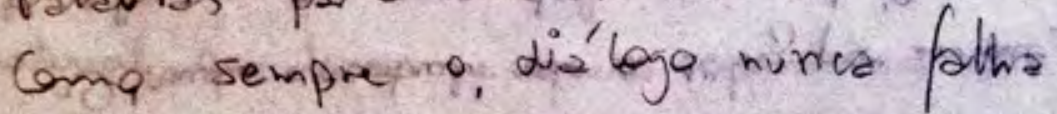

\section{SEMPRE RONTALL $\begin{array}{lll}1 & 1 \\ 0 & 0 & 0\end{array}$}

Olinar para

Othor

Othar,

fechar of othes...

vespior...

Other.

Seguir 
Alencar também estava assentando-se neste novo contexto, no campo de forças em que o sistemaprocesso desaguou. Íamos juntos descobrindo onde estávamos através das práticas, da organização das experiências que vivíamos e de reflexões sobre elas. Neste primeiro momento, até o dia em que, durante um ensaio sozinha, tive a inspiração para a nova organização da dramaturgia cênica ${ }^{40}$, eram recorrentes questões e dúvidas sobre:

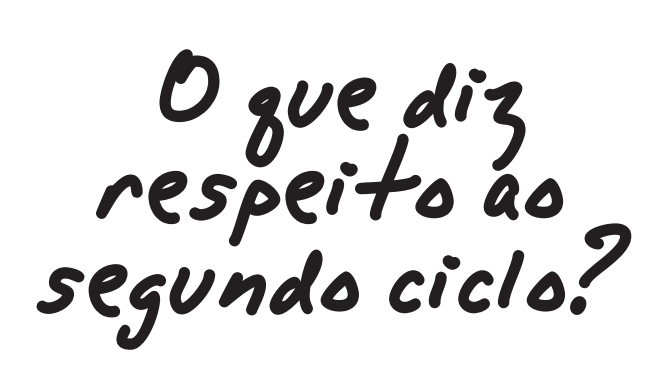

\section{Qual é a \\ forma do novo?}

\section{O que precisa
morrer de fato?}

Havia uma dificuldade de compreender o caráter cíclico do processo, de aceitar que nem tudo precisava ser destruído. Mas, ao mesmo tempo, parecia mais simples destruir tudo, falar que o processo acabou, e começarmos novamente, para aceitar e reconhecer o novo ciclo... Fomos lidando com essas questóes em nosso corpovoz, deixando ressoarem no espaçotempo de cocriação...

\section{$[\ldots]$ \\ descobre-se o}

simples por trás do complexo,

o que implica também no fácil, que

é a trajetória e o percurso de tudo o que acompanha o ciclo em vigência. Fluindo em acordo com as circunstâncias, evita-se o atrito, escapa-se ao desgaste. $\mathrm{O}$ caminho do fácil é duradouro e espontâneo, pois não exige esforço. Assim como a água descendo a montanha, diante de nada recua, diante de nada insiste; mergulha, desvia, contorna, adapta-se sem resistência e chega, pois, infalivelmente ao que lhe corresponde.

(I CHING, 2006,

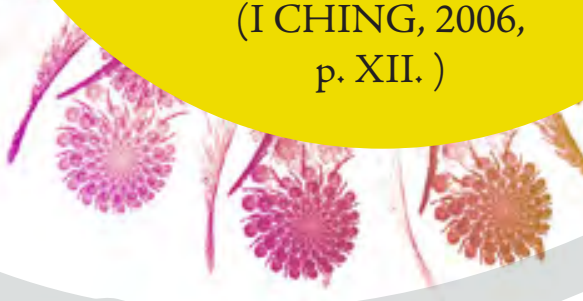

${ }^{40}$ Entrelaçamento com o texto da página 129. 
Quando a intuição da nova dramaturgia cênica surgiu como uma proposta concreta (propus de fato uma escolha e ordenação de cenas), esses questionamentos começaram a desintegrar-se, a dar espaço para outros.

\section{CADERNO DE RELATOS IV ${ }^{41}$}

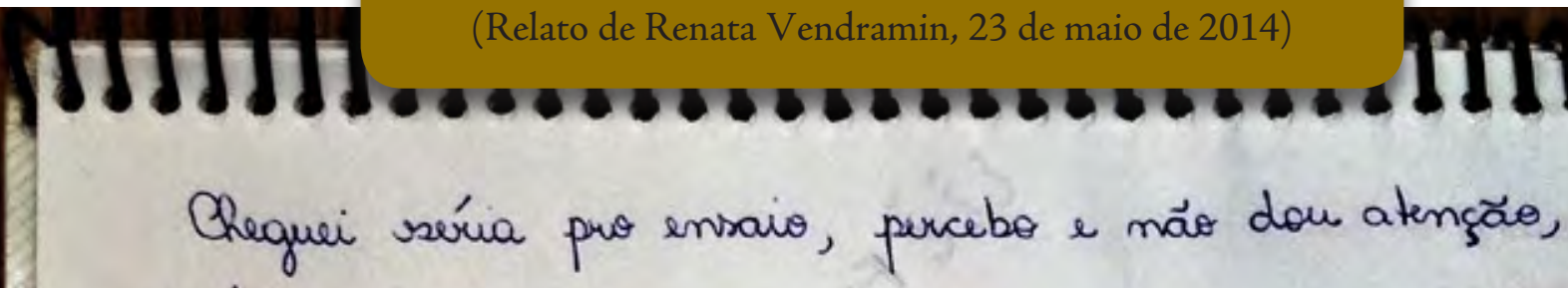
sige!

Parecia que algo estava chegando, querendo chegar...

Fiz o aquecimento integrado com infase na voz PI a relaçä do texto da' A.M.V.Q.T!

E na relaçäo com este texto: um micro do macro, (ume parte do fractal) organizi um roteiro o/ $\theta$ material que temos e quero apresentar esta sequiencia no dia 05/06/14:

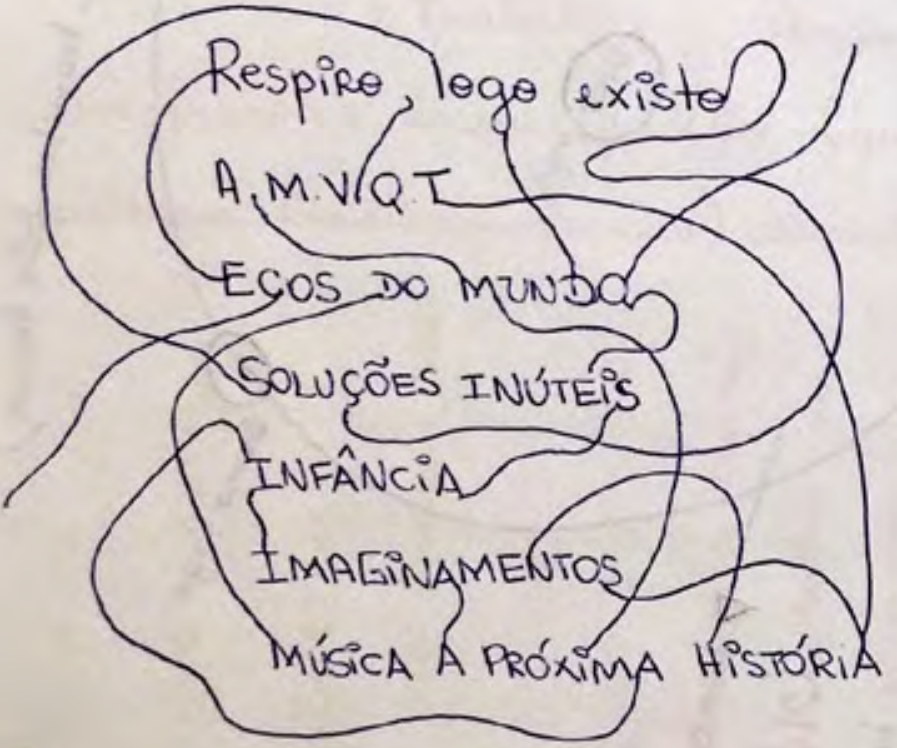

Tudo entrelaçado, um som, um movimento, uma palarra que leva a cutro estado, atmostera, passo, uneste trajeto poesia...

Sinto muita vontade de reter......

${ }^{41}$ A abreviação AMVQT, que aparece no relato, significa A Mais Velha que o Tempo. de canto da 
De fato o segundo ciclo começou a encarnar a partir desta proposição. Até então existia o vazio cheio de latências e saturações, até então voltamos a habitar este campo de forças, de infinitas possibilidades de cocriação, exercitando o repertório de práticas corpovoz, suportando estar neste sistema nervoso que é a peça, ainda com desejos e intuições muito informes, desejantes de encarnar, mas ainda num processo primevo de cocriação de sentidos e semsentidos. No entanto, só porque suportamos habitar o espaçotempo de cocriação neste primeiro momento, trabalhando juntos, respirando e praticando, em relação, uma inspiração materializou-se em proposta concreta que nos permitiu avançar na caminhada.

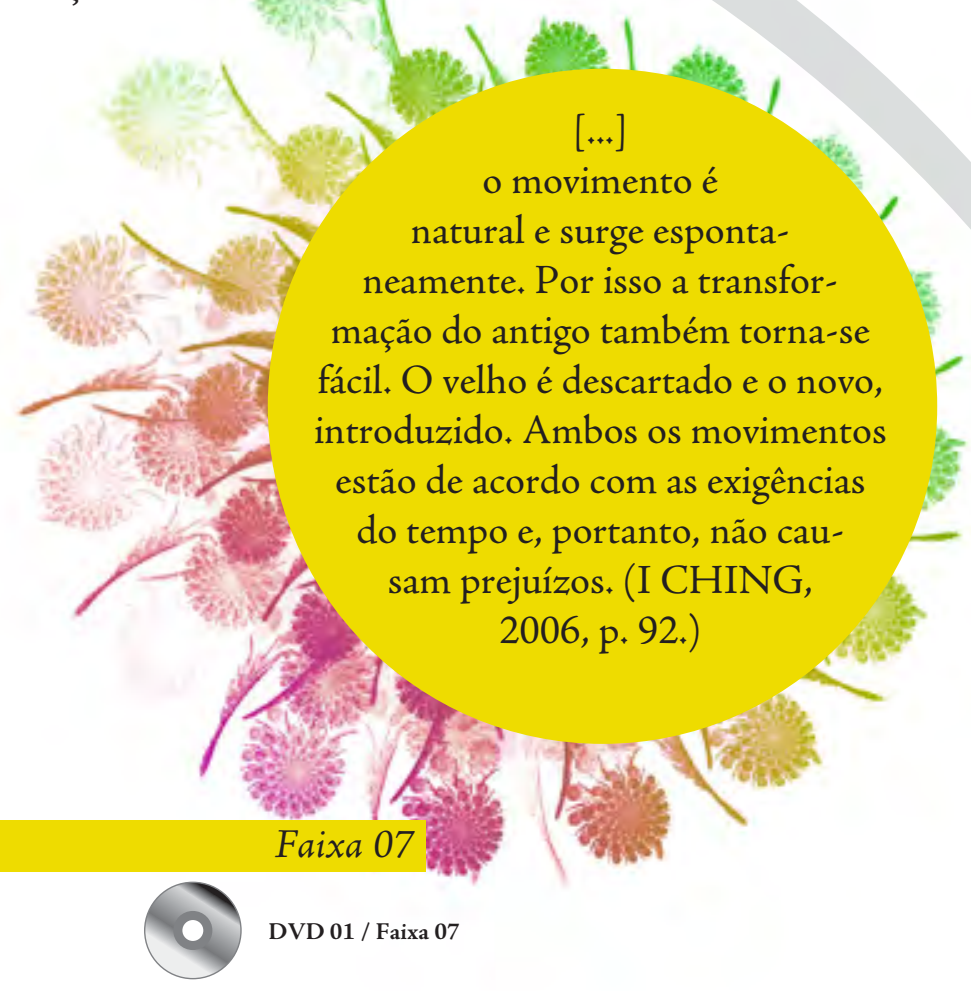

A prática dos relatos em vídeo, que nasceu neste segundo ciclo, foi e continua sendo um processo de aprendizado: escolher como posicionar a câmera, o que gravar, quais detalhes captar, exercitar nossa presença em frente à câmera, sem perder a espontaneidade e a liberdade, praticar articular a experiência e o pensamento em palavras, criar um discurso em palavras que ressoe a experiência do dia ou que a organize sem ter tempo para ficar refletindo muito a respeito. Quando terminávamos os ensaios, ainda estávamos assentando as vivências, e a proposta era justamente dar voz, encarnar em palavras, sensaçóes e sentidos, a partir deste corpovoz que estava pulsando a experiência do dia. Com o tempo, fomos e vamos encarnando esta prática. Além disso, com o caminhar da pesquisaexperiência, a tendência é deixarmos o discurso falado mais claro e repleto de sentidos e semsentidos, do que comparado ao início da experiência. A tendência é que nossas falas fiquem mais encorpadas, maduras e compartilháveis; que as palavras escolhidas para dar corpovoz ao discurso sejam selecionadas com mais primor e estejam coerentemente em sintonia com o todo. Nosso corpovoz também ressoa as falas com uma respiração mais expandida e integrada.

\section{Faixa 08}

DVD 01 / Faixa 08

Vale ressaltar que as práticas e vídeos aqui compartilhados têm a intenção de trazer um pouco a atmosfera do nosso espaçotempo de cocriação, os ritmos do trabalho, os tempos cultivados, a respiração do sistemaprocesso, os nossos silêncios, a textura dos nossos encontros.

A MANEIRA QUE TRILHAMOS PARA DAR-NOS

E

E S

$\mathrm{P}$

A

Ç

TEMPO

A nossa maneira. Um caminho possível. 



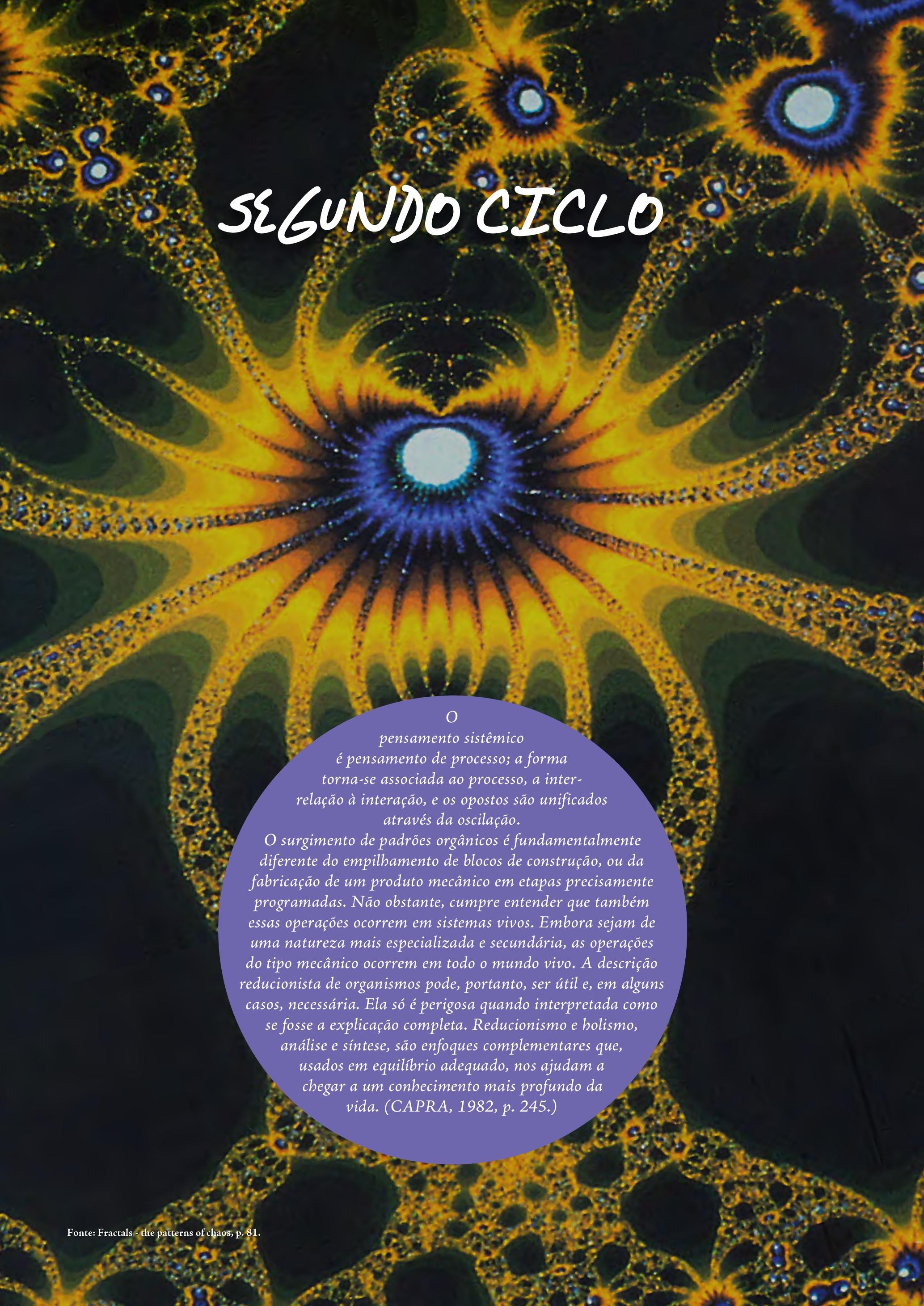




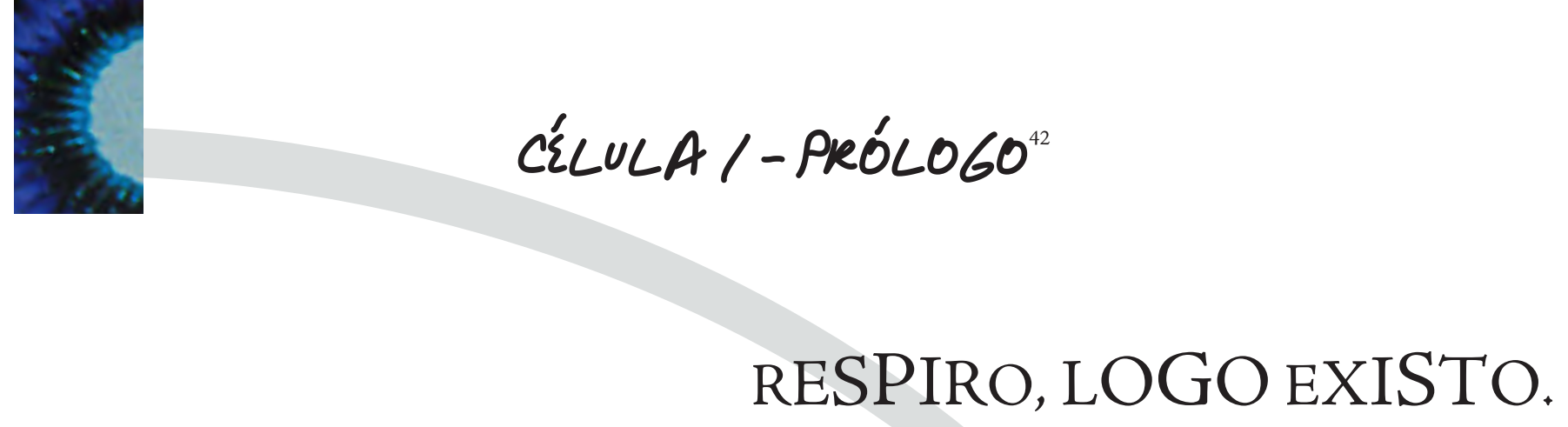

Não sei precisar em que momento essa frase ENCARNOU eM PALAVRA durante o sistemaprocesso. Sei que ela aparece escrita no final de uma folha de um dos cadernos de relatos, com a seguinte indicação:

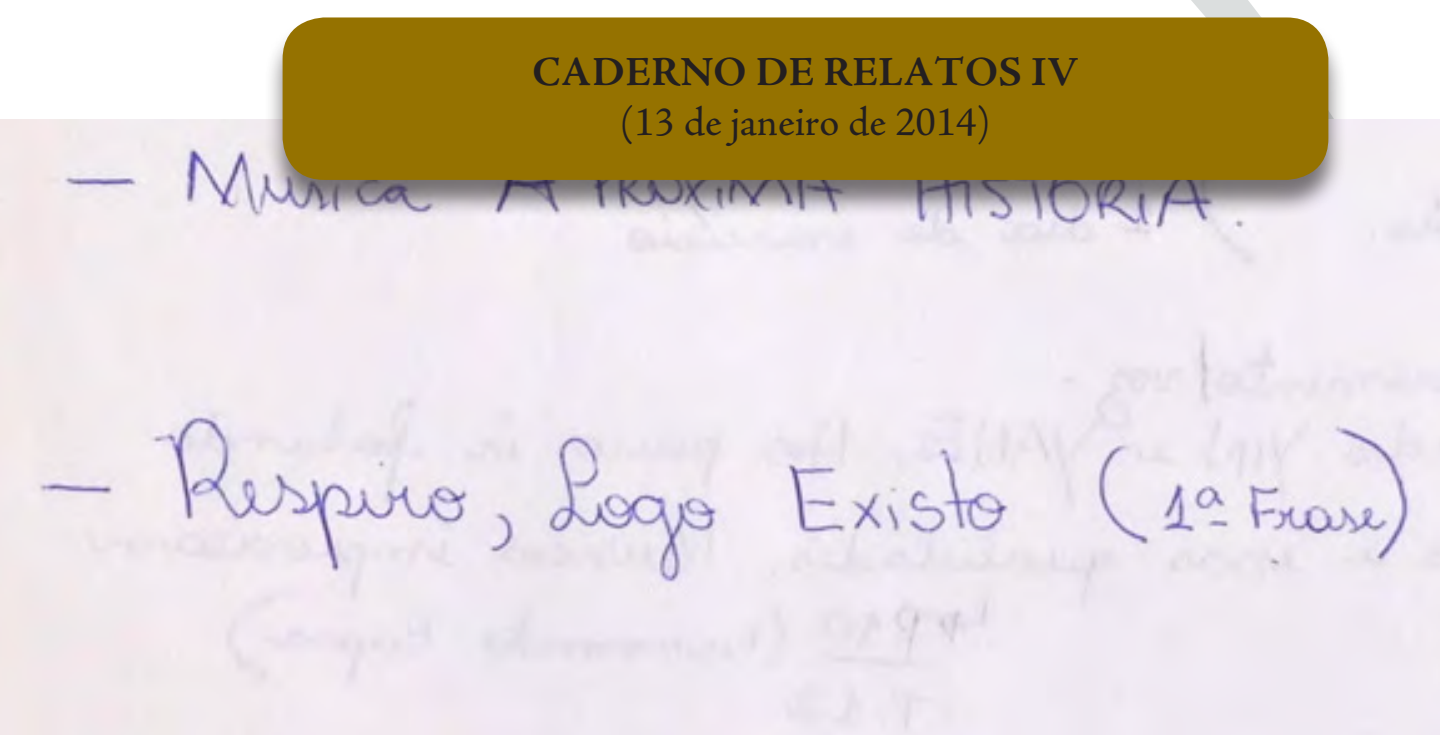

Eu fiz essa anotação no dia 13 de janeiro de 2014, no retorno das minhas férias de final de ano, em que havia decidido simplesmente respirar e deixar assentar o turbilhãocaóticoamedontrador da experiência que estava começando com o encerramento do primeiro ciclo do sistemaprocesso. Não tinha ideia do que aconteceria dali pra frente, tudo era desconhecido para mim, novas geografias estavam configurando-se. Estava feliz de Alencar estar comigo nesta empreitada de risco, e, para não desesperar de medo e angústia, restavam-me respirar, escutar e confiar na experiência que se revelava e já ganhava contornos.

Sei também, sem muita precisão de data, que em algum momento sentada no pequeno banco no centro da arena, relacionando-me com o texto de $A$ Mais Velha que o Tempo, pareceu-me muito coerente dizer essa frase antes de começar a encarnar a narrativa da velha. Depois, ainda me pareceu bastante coerente dizer que essa frase era o prólogo e, dessa maneira, expandir o instante de encarnação dessas palavras no espaçotempo de cocriação, a ponto de estabelecer uma atmosfera para iniciar a experiência da peça.

Essa é uma frase curta, que sintetiza muitas das ideias da peça e indica para o público qual a qualidade de pensamento que guia a experiência que vai começar. Além disso, ela nos trouxe a oportunidade de cocriar uma atmosfera para o início da peça, em que convocamos os nossos corações e a nossa escuta para cocriarmos uma experiência.

42 Neste e em todos os demais textos que se seguem, relato com mais detalhes a trajetória de cocriação de cada uma das células da peça. Contudo não narrarei o processo de cocriação da direção de arte, abordando com minúcia esse trabalho realizado, que abarca os figurinos, a maquiagem, a iluminação, os objetos de cena, todos tão essenciais para a peça, e que só foram possíveis cocriar com a chegada da diretora de arte Marisa Rebollo, que, assim como Alencar, tem uma presença de escuta, sensível em tecer em cocriação. Em um texto ou outro, acabo falando sobre um ou outro elemento de cena que foi trazido a partir do trabalho das artistascriadoras; no entanto, não detalho a relação de cocriação que também se estabeleceu com a diretora de arte Marisa, simultaneamente com todas as outras relações. Essa foi uma escolha necessária por questões de organização da dissertação, a fim de que o texto não se expandisse demais. 


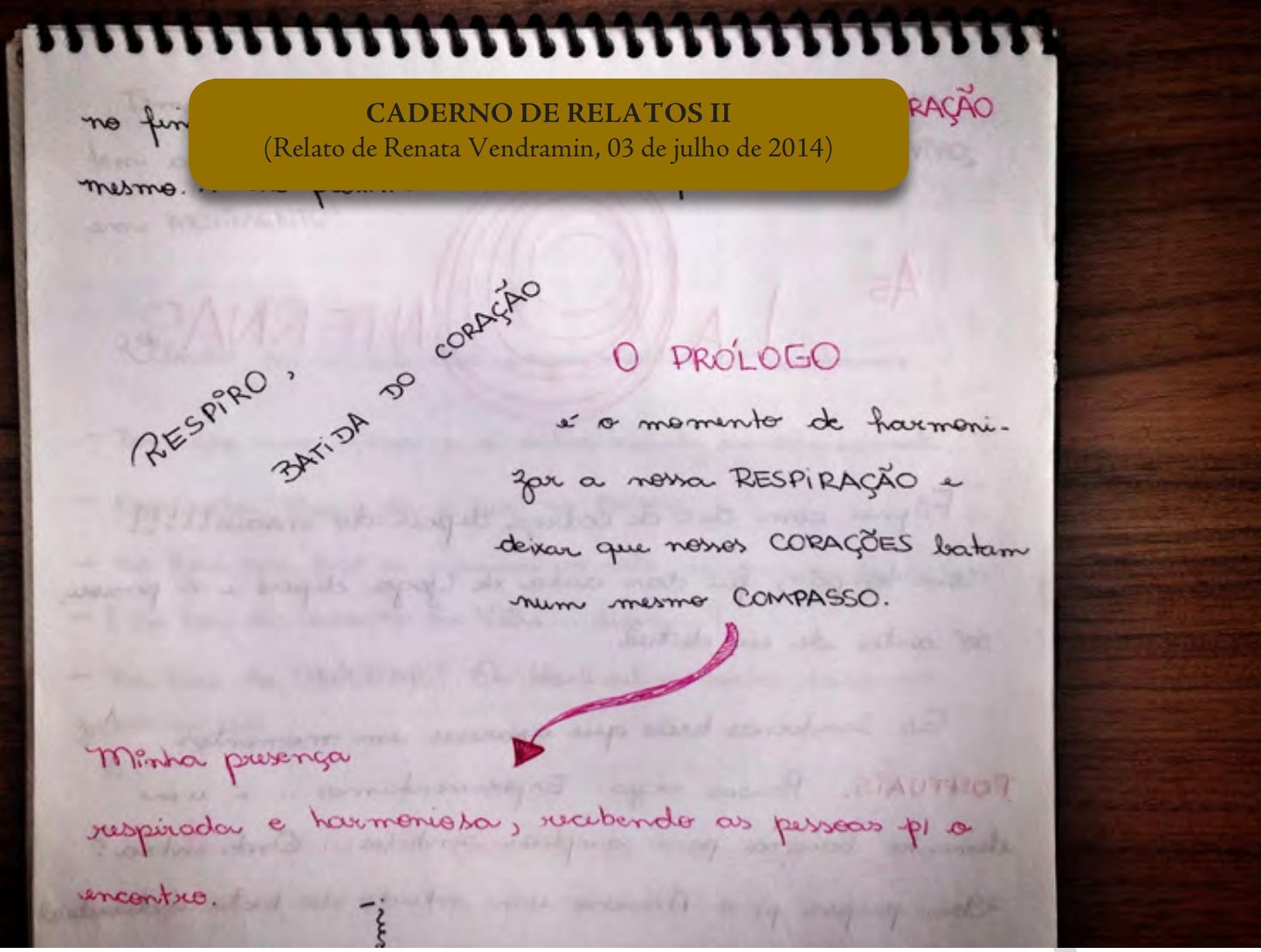

Até configurar-se nesta forma sintética, a viagem pelos "prólogos" (ou por um texto inicial que trouxesse em palavras o universo que iríamos adentrar) foi vasta, desde o primeiro ciclo.

Quando delineamos a trajetória da primeira dramaturgia cênica para a abertura de processo em dezembro de 2013 (quando Janaína ainda estava presente), decidimos que a Figura Mítica (um dos desdobramentos da vó ancestral) iniciaria a peça. Na sequência da célula em que ela aparecia, durante algum tempo, deixamos o espaço vazio, correspondendo a uma célula, para trazer possibilidades deste texto inicial, que seria a segunda célula. $\mathrm{O}$ desejo era abrir espaço para algumas reflexóes mais expandidas do que vínhamos vivenciando, com humor e cumplicidade. E tínhamos um desafio grande: a cocriação da teia dramatúrgica não pressupõe a criação de uma dramaturgia com começo e fim, de maneira linear e conclusiva. Como então iniciar a peça? Convidar o público para adentrar nessa experiência teatral? Mergulhadas nos desejos, desafios e reflexões, propusemos.

\section{Faixa 09}

O processo de escrita dos textos, de encarnar em palavras nossas ideias, sentimentos, reflexóes, sentidos e semsentidos, e, depois disso, o processo de encarnar as palavras (esses sopros de sentidos etéreos) em corpovozmovimento, seguiram o mesmo fluxo.

Exercitamos "a escrita de textopalavras", assim como exercitamos "sentar no pequeno banco, o nosso iamá", assim como exercitamos "a musculatura do nosso corpo" para ampliarmos nossas possibilidades de criação de movimentos, assim como exercitamos "abrir espaços no corpo" para nossa voz ressoar, assim como exercitamos "o toque do tambor" para harmonizar os nossos ritmos, assim como tantas outras práticas que se complementam EM REDE para disponibilizar todos os dons, as possibilidades criativas da artistacriadora para encarnar a sua arte - no nosso caso, nossa poesia cênica. E, ao encarnar essa rede de práticas, ao nos disponibilizar para ativar essa consciência, entramos em fluxo criativo, ganhamos ritmo de criação. 
Exercitando ainda o "não-julgamento", recebemos as cocriações em escuta, conscientes de que nem tudo ficaria, nem tudo seria maturado, nem tudo seria lapidado. Muitas coisas passaram por nós e ficaram saturando o nosso espaçotempo de cocriação. Disseram respeito à caminhada, foram criações de passagem, que permitiram que déssemos os próximos passos na cocriação da nossa trajetória.

No mesmo período de experimentaçóes mostrado na Faixa 09, Janaína trouxe algumas propostas de movimentos corporais e imagens, em que mexíamos com fios de linhas emaranhados. Suamos todas essas proposições; no entanto, no fluxo do sistemaprocesso, reconhecemos que nenhuma das nossas propostas foi coerente e lapidada o suficiente para ser integrada à teia dramatúrgica.

Depois da abertura de processo em dezembro de 2013, em que tiramos a Figura Mítica (A Mais Velha que o Tempo) da peça, retornou ainda mais forte a questão: como iniciar a trajetória da peça?

Janaína ainda trouxe uma músicanarrativa como proposta, que acabou desdobrando-se, no fluxo do processo, na célula 3 (Ecos do $\mathrm{Mundo}^{43}$ ). Mas logo encerramos o primeiro ciclo, sem solucionar criativa e cenicamente essa questão.

No segundo ciclo, além da frase "respiro, logo existo", chegou ao espaçotempo de cocriação um novo elemento: a OCARINA, instrumento musical trazido da minha viagem à Colômbia, que carinhosamente passei a chamar de VUuU ANCESTRAL.

O primeiro dia em que levei a ocarina para o ensaio, foi também o dia em que intui a nova configuração da dramaturgia cênica, e a frase "respiro, logo existo" iniciava a trajetória da peça nesta proposta. A ocarina se integrou à teia de maneira muita harmônica, como um ELEMENTO DE ENTRELAÇAMENTO. Ela passou a compor tanto a atmosfera da célula 1 (Prólogo), quanto a atmosfera da célula 2 (A Mais Velha que o Tempo). Possibilitou um trânsito suave entre uma célula e outra, que era a intenção deste momento.

No entanto, mesmo com a ocarina e com a frase "respiro, logo existo", tive dúvidas se era necessário trazer para este momento inicial, o prólogo, a pergunta que guia a peça, se era importante refazê-la para todos que compóem o círculo: "Se este mundo em que a gente vive estivesse grávido, como você imagina que seria o outro mundo que vai nascer?". ${ }^{44}$

Também tive vgntade de convidar um amigo poeta para escrever outro texto, MAIOR, MAIS poético, para iniciar a teia dramatúrgica, assim a frase "respiro, logo existo" iria também para a zona de entrelaçamento das células. Aos poucos, fazendo, compartilhando com cocriadores, sentindo a ressonância nas pessoas, fui reconhecendo que essas eram dúvidas e desejos que abriam inúmeras possibilidades, mas que o momento pedia um recolhimento, um escutar o que já estava, a teia já estava, não era necessário MAIS coisas, era preciso somente respirar, abrir a escuta...
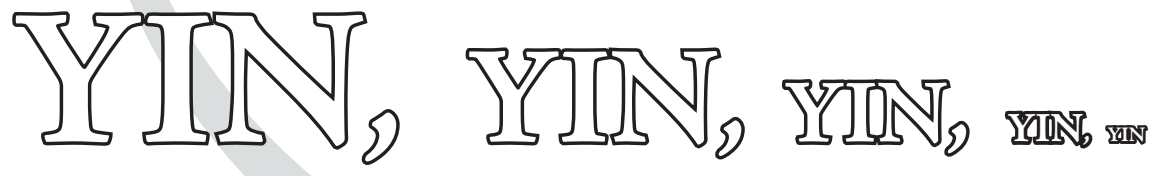

... escutei, então, o som do coração. 


\section{Faixa 10}

DVD 01 / Faixa 10

\section{CADERNO DE RELATOS II}

\section{(Relato de Renata Vendramin, 03 de julho de 2014) \\ $\operatorname{sintond}$ \\ Trabalhe \\ para que consigames em breve realizar o treinamento todos os dias!}

Trounce tbm uma proposta pi o Prólogo: o tambor entrar com o toque do coraçäo. Passamos algumas vezes mas o Alencar precisa trabalhar mais o toque do tambor $p 1$ conseguir tirar um som que traga o. fluxe, o pubso que a cena pede. Ele concorda! Seguimos Experimentando com s sem a batida...

No final deste ensaio, Alencar propôs trazer a BATIDA DE UM CORAÇÃo de verdade, gravada, já que estávamos usando o recurso do áudio gravado também na célula 2 (A Mais Velha que o Tempo). Assim não precisaríamos ter o tambor na cena somente neste momento. No ensaio seguinte, experimentamos esta proposta $e$ gostamos muito de como aconteceu. Acordamos que eu falaria: "respiro", entraria o som da batida do coração, que ficaria até eu dizer: "logo existo".

O tempo entre "respiro" e "logo existo" seria determinado a cada encontro, dependendo da necessidade do dia. Um tempo justo para começarmos a respirar juntos, ativarmos a nossa escuta para percorrer a geografia da peça. Naturalmente, durante o compartilhar com cocriadores, tive vontade de estabelecer contato visual com cada uma das pessoas presentes no círculo, e este tornou-se um momento de olharmos uns para os outros e sentirmos a batida do nosso próprio coração.

Acredito que uma das ações mais ORIGINAIS (que tem a ver com ORIGEM) é escutar o SOM DO CORAÇÃO, a batida que determina o pulso das nossas vidas, que delimita o início e o fim da nossa existência neste corpo... 


\section{CÉLULAZ-A MAISVELHA QUEO TRPO}

A semente para a cocriação desta célula germinou em um reencontro com o livro de Clarissa Pinkola Estés: Mulheres que Correm com os Lobos: mitos e histórias do arquétipo da mulher selvagem. Livro que ganhei e li pela primeira vez em 2005. Um dos livros que mais me transformaram, "tocó a la puerta", como diria Estés. Mais especificamente o reencontro foi com a seguinte narrativa:

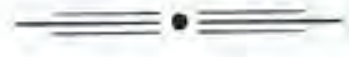

La Loba

Existe uma velha que vive num lugar oculto de que todos sabem, mas que poucos já viram. Como nos contos de fadas da Europa oriental, ela parece esperar que cheguem até ali pessoas que se perderam, que estảo vagueando ou à procura de algo.

Ela é circunspecta, quase sempre cabeluda e invariavelmente gorda, e demonstra especialmente querer evitar a maioria das pessoas. Ela sabe crocitav e cacarejar, apresentando geralmente mais sons animais do que humanos.

Dizem que ela vive entre os declives de granito decomposto no território dos índios tarahumara. Dizem que está enterrada na periferia de Phoenix perto de um poço. Dizem que foi vista viajando para o sul, para o Monte Alban' num carro incendiado com a janela traseira arrancada. Dizem que fica parada na estrada perto de El Paso, que pega carona aleatoriamente com caminhoneiros até Morelia, México, ou que foi vista indo para a feira acima de Oaxaca, com galhos de lenha de estranhos formatos nas costas. Ela é conhecida por muitos nomes: La Huesera, a Mulher dos Ossos; La Trapera, a Trapeira; e La Loba, a Mulher-lobo.

O único trabalho de La Loba é o de recolher ossos. Sabese que ela recolhe e conserva especialmente o que corre o risco de se perder para ó mundo. Sua caverna é cheia dos ossos de todos os tipos de criaturas do deserto: o veado, a cascavel, o corvo. Dizem, porém, que sua especialidade reside nos lobos.
MULHERES QUE CORREM COM OS LOBOS

Ela se arrasta sorrateira e esquadrinha as montañas e os arroyos, leitos secos de rios, à procura de ossos de lobos e, quando consegue reunir um esqueleto inteiro, quando o último osso está no lugar e a bela escultura branca da criatura está disposta à sua frente, ela senta junto ao fogo e pensa na canção que irá cantar.

Quando se decide, ela se levanta e aproxima-se da criatura, ergue seus braços sobre o esqueleto e começa a cantar. É aí que os ossos das costelas e das pernas do lobo começam a se forrar de carne, e que a criatura começa a se cobrir de pêlos. La Loba canta um pouco mais, e uma proporção maior da criatura ganha vida. Seu rabo forma uma curva para cima, forte e desgrenhado.

La Loba canta mais, e a criatura-lobo começa a respirar.

E La Loba ainda canta, com tanta intensidade que o chão do deserto estremece, e enquanto canta, o lobo abre os olhos, dá um salto e sai correndo pelo desfiladeiro.

Em algum ponto da corrida, quer pela velocidade, por atravessar um rio respingando água, quer pela incidência de um raio de sol ou de luar sobre seu flanco, o lobo de repente é transformado numa mulher que ri e corre livre na direção do horizonte.

Por isso, diz-se que, se você estiver perambulando pelo deserto, por volta do pôr-do-sol, e quem sabe esteja um pouco perdido, cansado, sem dúvida você tem sorte, porque La Loba pode simpatizar com você e lhe ensinar algo - algo da alma.

$$
\underline{\underline{(E S T E ́ S, 1994, p .43 .)}}
$$

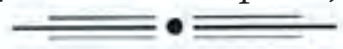

Cheguei até ao livro e a esta narrativa intuitivamente, buscando por referências, imagens, sonoridades, palavras, movimentos que me permitissem chegar mais perto da figura que, no início, chamávamos de "avó ancestral”, "a vó da vó", a "mulher das raízes", entre tantos outros nomes que surgiram durante o sistemaprocesso de cocriação da peça...

\section{Faixa 12}

DVD 01 / Faixa 12

Num primeiro momento levei para a cena a história original de La Loba, com o intuito de deixar a narrativa ressoar em meu corpovoz, em meus sentimentos, sentidos e semsentidos. Assim como fiz com diversas narrativas pessoais, sentei no pequeno banco de madeira - o nosso iamá - para narrar esta história.

A partir da experiência de ${ }^{\mathrm{EN}}{ }_{\mathrm{CA}} \mathrm{RNAR}$ essa narrativa no espaçotempo de cocriação sentada no banco de madeira, e já chocando muitas reflexões, imagens, intuições, sobre o que seria essa figura arquetípica que buscávamos e a maneira de materializá-la na cena, nasceu a primeira versão do texto, que escrevi em casa, depois do ensaio, organizando a experiência da prática. Ainda tinha o nome "A Mulher-lobo", e nesta primeira reescrita do texto, sempre nascendo em diálogo com a experiência da cena, o objetivo era trazer essa figura mais próxima do nosso imaginário brasileiro, para o nosso contexto cultural. Todas essas experimentaçóes aconteciam em 2012, eu ainda não havia ingressado no mestrado, trabalhávamos somente Janaína e eu. 
Existe uma velha que vive num lugar oculto, de que todos

1. texto reescrito.

(1) sabem, mas que poucos já viram.

Ela parece esperar que cheguem até ali pessoas que se perderam, que estão vagando ou buscando por algo, a pruccura da sua história.

Ela é curcunspecta, quase sempre cabeluda, e tem ancas largas. Elodemonstra especialmente querer evitar a maioria das pessoas. Ela sabe crocitar e cacarejar, salue mais sons animais do que humanos.

Dizem que ela vive/ Muma cidade submersa.

Dizem que entántervada coração da floresta amazônica, debaixo de uma seringueira. Niziem que foi vista viajan do para o Sul, para as lataratas do Sguaçu, num carro incendiado com a janela traseira arrancada. Oigem que fica parada ma estrada perto de lorumbá, que pega carona aleatoriamente com caminhoneiros até a Bolivia. Dizem que é possível senti-la entre a chacra cardíaco e o chacra laxíngeo na altura da $\underline{2^{a}}$ vértebra torácica.

Ela é conhecida por muitos nomes: la huesera (A mulherosso); la trapera (A Trapeira); e la loba (A mulher-lobo).

(1) único trabalho da mulher-lobo s'o de recolher Ossos) Sabe-se que ela recolhe e conserva puncipalmente os que correm o rusco de se perderem para

a humanidade

113 
Sua caverna é cheia dos ossos de todos as tipos de criatura: veado, cascavel, corvo, onça.

Dizem, porém, que sua especialidade reside nos lolos

Ela se evrcasta sorrateira por entre a Mata, percovere montanhas, leitos secos de rios, 'a procura de ossos de bobos e, quando consegue reunir um esqueleto inteiro, quando o último cosso está no lugar, e a bela escultura branca da criatura ustá disposta ia sua frente, ela senta junto ao fogo e pensa na canção que irá cantar.

Quando se decide, ela se aproxima da criatura, ergue ssus braços sobre o esqueleto e começa a cantar.

E á que as ossos das costelas e das pernas do bobo comefam a se forrar de carne, que o corpo da criatura comesa a se cobriv de pílos.

canta um pouco mais, e a criatura vai ganhando vida. Seu rabo forma uma curva para sima, forte e desgrenhado.

C.mulher-lobo canta mais e a criatura-lobo começa a respirar.

La loba ainda canta, com tanta intensida de que o chão estremece e, enquanto canta, a lobo abre as olhos, dá um salto e sai correndo pelo desfiladiro.

114 
Em algum ponto da corrida, seja pela velocidade, por atravessar um rio respingando cígua, seja pela incidência de um raio de sol ou de lua sobre seu corpo, / o lobo de repente e' transformado numa mulher? que ri e corre livre na direção do horizonte.

Por isso, diz-que, se um dia você estiver cansado, perdido confuso, cante! Sizem que la ldea se aproxima do alento de qualquer criatura que cante es se ela simpatizar comvocî pode the ensinar algo - algo da alma.

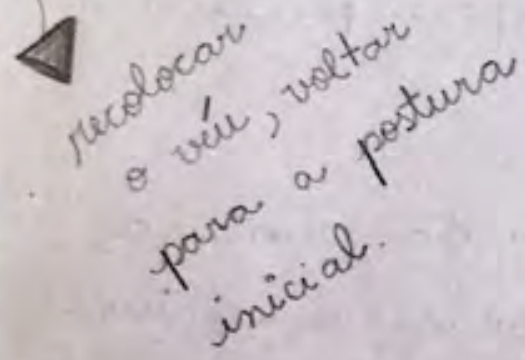

Depois desta primeira reescrita, fiz o exercício que chamava na época de escrita automática (fazendo referência ao método de escrita criado pela vanguarda surrealista que buscava um fluxo do inconsciente do artista), e que escolhemos chamar, mais tarde, em nosso sistemaprocesso, de Escrita em Fluxa. A ideia era deixar fluir a criatividade livremente nas camadas conscientes e inconscientes.

Trago a folha do caderno de relato em que fiz a escritaemfluxo da Anciã. A intenção deste exercício era mergulhar na imaginação, ativá-la, escrevendo livremente no papel: quem é essa figura? O que ela é? O que lembra? O que parece? Quais as metáforas e metonímias que a representam? Que imagens têm? Que cheiros? Que texturas? E quantas outras perguntas atravessarem quem o realiza. Foi um...

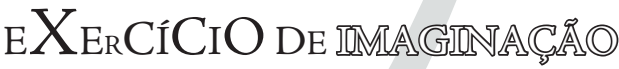
FLUXO L I V R E

...que ficou ali registrado, disponível, para consultarmos e reconsultarmos sempre que tivéssemos vontade.

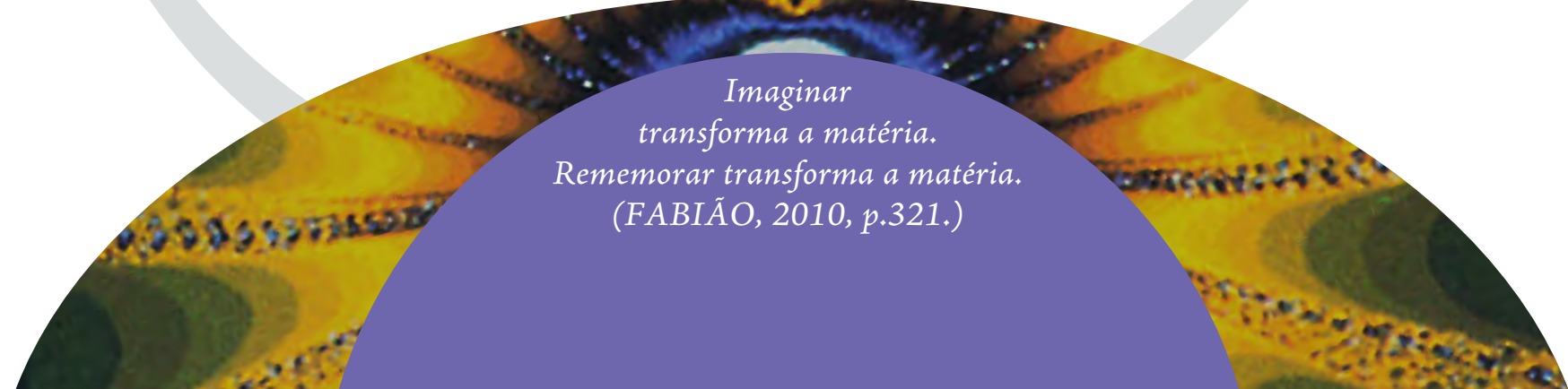




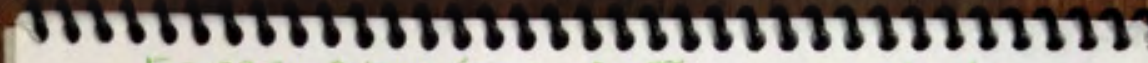

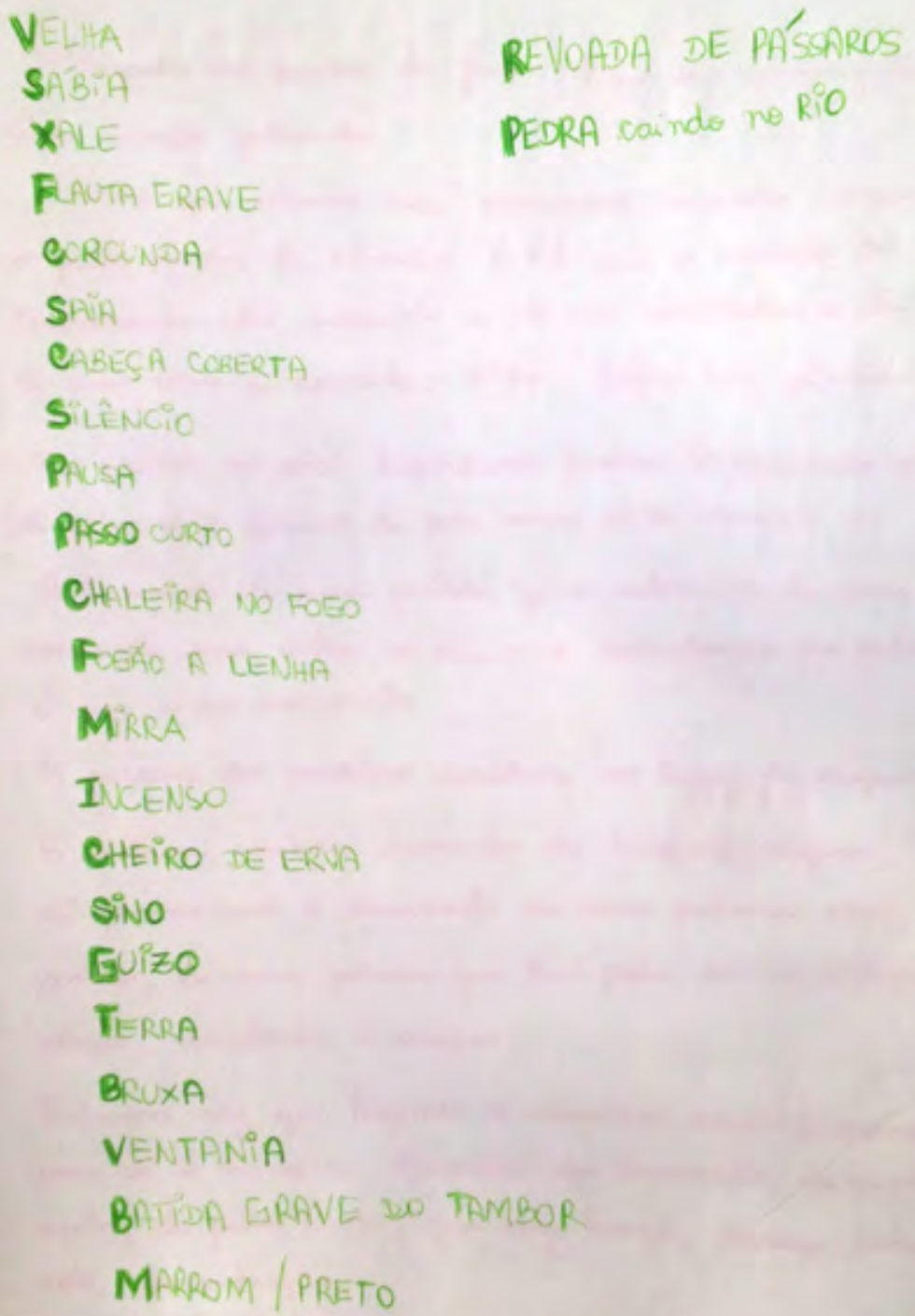

Com a primeira reescrita pronta, retornei para a prática da cena. No original do texto acima, escrito à mão, existem inclusive algumas indicações do uso de um adereço (um tule que cobria minha cabeça) e de indicações de mudança na respiração, que estava experimentando.

Por esta época, mergulhada na investigação, também me encontrei pela primeira vez com outro livro de Estés, chamado A Ciranda das Mulheres Sábias. Fiz algumas anotações que culminaram em mudanças mais significativas do texto:

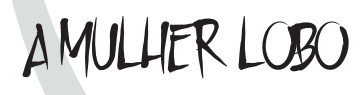

\section{TRASFORMOU-SE EM}

\section{AMAISVELHA QUE OTEMPO}

Vale sempre lembrar que a cocriação das células da peça acontecia de maneira simultânea,EM REDE. Enquanto eu me dedicava a este texto, Janaína dedicava-se a outro, compartilhávamos coisas, e assim íamos alimentando uma a outra e o sistemaprocesso como um todo. $\mathrm{O}$ que ela criava influenciava na minha criação e vice-versa, mesmo que não existisse uma relação direta de forma ou conteúdo com o que criávamos individualmente. Assim tecíamos a TEIADRAMATÚRGICA, ainda muito informe, em rede, em COCRIAÇÃO. 

Estudos: Mulheres que correm com as Lobos $/$ Al Pranda das Mulheres
Sábras. La loba, la que sabe

\section{É mais vello que o tempo;}

É a memória arquivada das intencoús fémininas;

Suus bigodes prosentem o future;

Ela rraja simultaneamente para funte e para trás no tempo; squilibrande um lado com a dança que realiza com o outre,

Sous instintos para as estaçoes, para a vida, t a açäs ética.

Ce arte de dizer verdades

Espínto aburto ass ventos;

Avós guardiás;

Mulherws das Raízes;

qui enfiaram em irsossos bobsos mapas do tersuro dolevados;

es purímetros e es portais do mundo da alma confiados a slia guarda;

a velha sábia da psique;

Por alma no que diz;

Ser an motas fundamentais;

Nestas anotações que fiz a partir da leitura dos livros de Estés, colhi frases, imagens, palavras, ideias que faziam sentido pra mim, que eu intuía que se relacionava com a figura que desejava encarnar em cena. A relação com a poesia do texto de Estés e das narrativas que ela traz nos seus livros também inspiraram a escolha da minha forma de escrita. Como se a minha escrita nascesse dessas palavras, se desdobrasse delas, em conexão e sintonia com elas. 
PARI A SeGUNDA ESCRITA:

le mais velha que o tempo

29 texto $06 / 02 / 13$ reescrito

Existe uma velha que vive num lugar oculto, de que todos salem, mas que poucos jó viram.

Ela parece esperar que cheguem até ali pessoas que se perderam, que estäo vagando, a procura da sua própria história.

$\rightarrow$ Sus bigodes pressentem a futuro. Ela vaja semulta

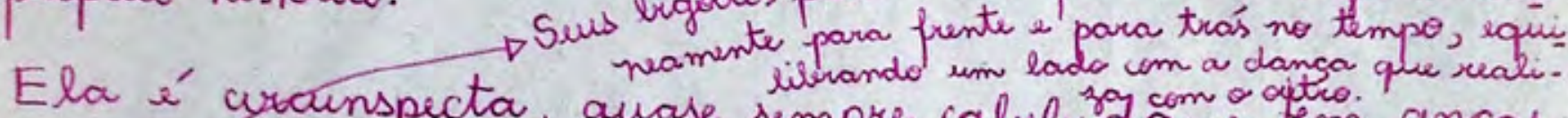

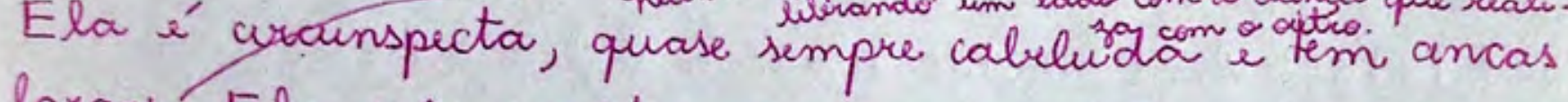
largas. Ela sabe crocitar e cacarejar, sabe mais sons animais do que humanos.

Dizem que ela vive numa cudade submersa. Dizem que está enterrada no coração da floresta amazónica, debaixo de uma seringueira. Oigem que fa vista viajando para o Sul, para as lataratas do Sguagu, num carro incen diado com a janela traseira arrancada. Dizem que os pássaros the contam as noticias ocultas e as historias de vida. Dizem que ela fica parada na estrada perto de Corumbá, que pega carona aleatoriamente com caminho neiros até a Bolvivia. Ouzem que é possivel senti-la intre o chacra candíaco is chacra laríngeo na altura da 2 a vertebra torácica.

Ela é conhecida por muitos nomes: a mais velha que o tempo, a avó guardiã, a mulher das raúzes, que infiou em nossos bolsos mapas do tesouro dobrados.

118 
(1) único trabalho da 'Mais velha que otempo' é tecer a rede de histórias. Sabr-se que recolhe e alinhava principalmente as que correm o risco de se perderem para a humanidade.

Sua caverna é chéia de histórias de todos as tipos: antigas, inventadas, vividas, esquecidas, rejeitadas, desconhecidas, prenunciadas.

Todas alinhavadas uma a outra, diariamente, num sacro ofício, dia a dia tecendo a rede de histórias.

* Se algum dia vocî estiver cansados perdide, em lewsca de sua propria história, cante. Deszim que a 'mais velha que o tempo' see aproxima do alento de qualquer criatura, que cante. *

\section{Faixa 13}

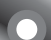

DVD 01 / Faixa 13

O parto do texto foi natural: trabalhoso e orgânico. A maneira como escolhemos habitar o espaçotempo de cocriação, durante todo o trabalho, teve a intenção de nos conduzir, artistascriadoras que somos o sistemaprocesso, a momentos como este: em que a imaginaçãointuiçãosemsentidosreflexãosentimentosentidos, o material interno que a artista vem gestando, ainda muito etéreo, ganhe uma forma, exploda em forma artística:

\section{SPHIOTA! , amondian Brople}

Estávamos sempre muito atentas para receber as formas que nasciam, com cuidado e carinho, sabendo que ainda estavam em desenvolvimento, modificando-se, ajustando-se, talvez nem ficassem na peça, mas iriam nos auxiliar a dar o próximo passo de que o sistemaprocesso necessitava, que pedia que fosse dado. Receber sem julgamentos e sem ânsia de querer entender para que serve dentro do todo, ou de querer encaixar em algum lugar, é muito importante. $\mathrm{O}$ mais interessante é receber com a ESCUTA aberta para aos poucos descobrirmos os sentidos e semsentidos que as criações vêm encarnar em relação.

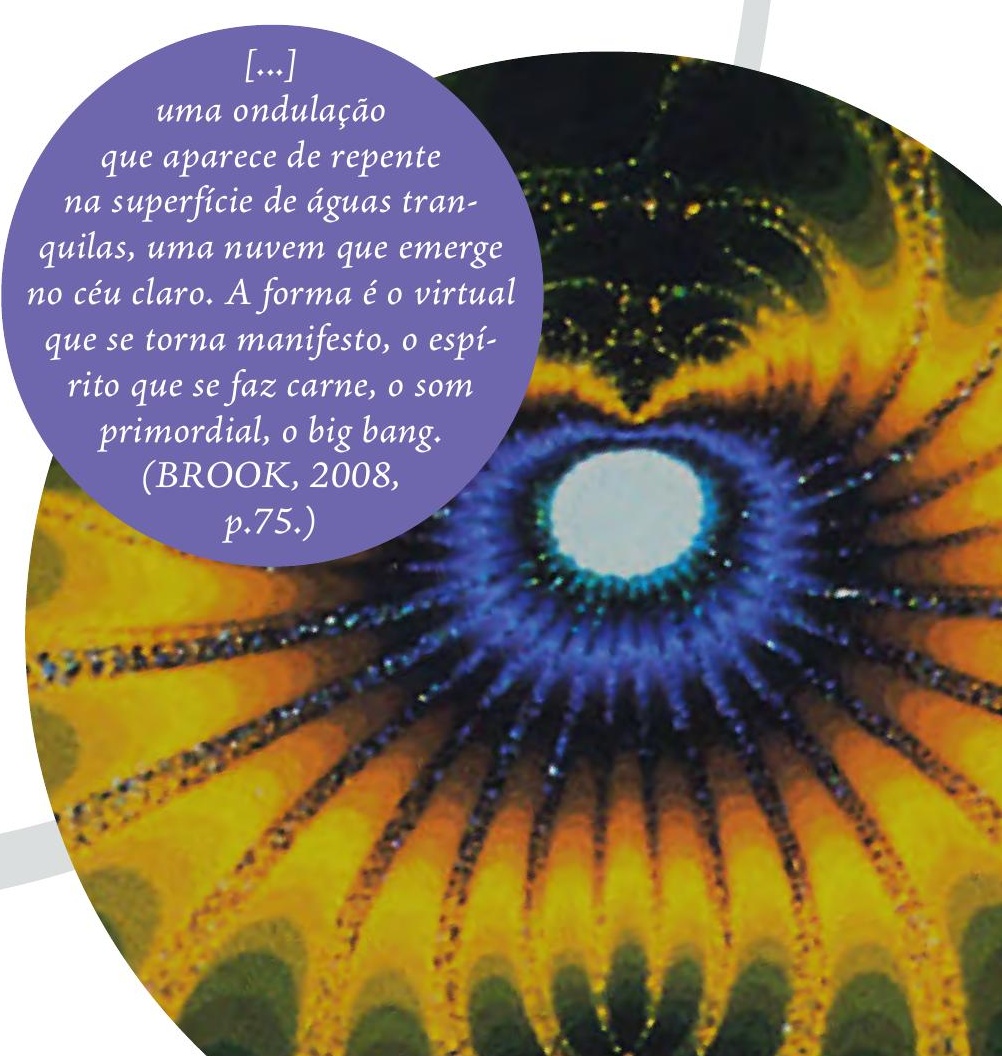


Eu, artistaparideira, recebo as minhas criações em escuta.

Sou guardiã desses embriões.

Girinos que nadam vibrantes em movimento intenso.

Sentidos desconhecidos que se desenham no espaçotempo.

Sentimentos indecifráveis que abrem espaços no corpovoz.

Abro espaço. Dou tempo.

\section{ESPACQO-ME. TEMPO-ME.}

Esvazio-me de mim, para ser fecundada pela criação.

Recrio-me.

Com a segunda reescrita do texto, revelou-se a necessidade de começarmos a trabalhá-lo juntas: Janaína e eu. Começamos experimentando livremente o texto nós duas, de maneira muito livre e por vezes caótica, até evoluirmos para o exercício do Espaço do Círculo ${ }^{45}$, criado a partir da leitura de Brook. O exercício nasceu da necessidade do sistemaprocesso, de organizá-lo. A intenção era que a organização auxiliasse na liberação de nosso fluxo e ritmo criativos.

Lançamo-nos para dentro do círculo. Naquele momento, riscávamos um círculo de giz no chão. O texto ia sendo memorizado durante os improvisos. As folhas de papel com o texto escrito ficavam disponíveis na borda do círculo para consultarmos quando necessário. Instrumentos musicais também ficavam na borda para serem usados. Assim, iniciamos a nossa relação com o texto (sua musicalidade, seus movimentos), entre nós duas através do texto, com nossos corposvozes na cocriação do corpovoz dessa mulher: A Mais Velha que o Tempo. Surgiram imagens, movimentos, músicas, sons, maneiras de dizer o texto, de ser narradora e de ser a velha...

\section{Faixa 14}

DVD 01 / Faixa 14

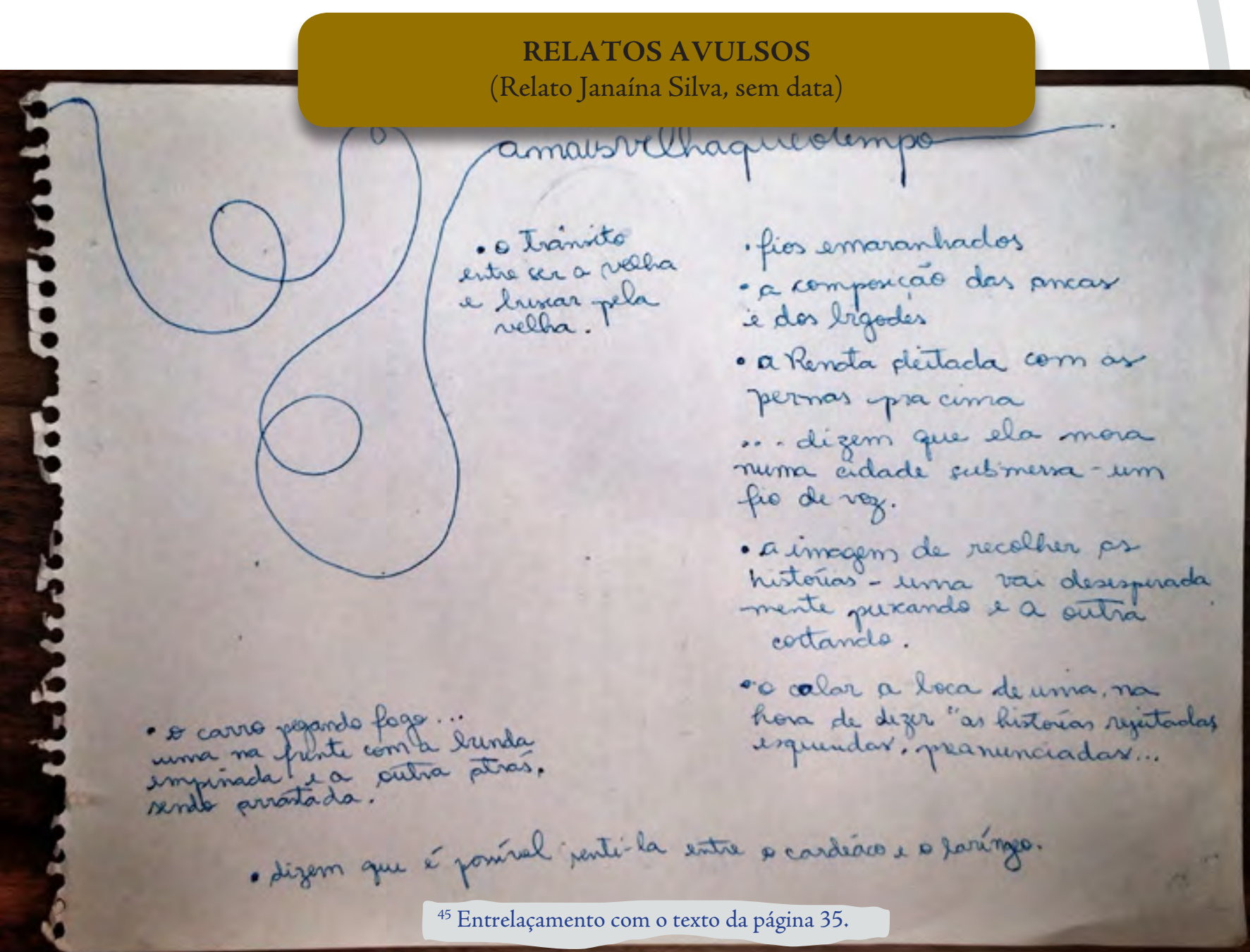


Em um determinado momento do sistemaprocesso, quando outras células começaram a ser estruturadas, o texto de A Mais Velha que o Tempo ficou descansando. Depois, ele parecia não ser coerente com a teia dramatúrgica como texto a ser encarnado por nós, atrizescriadoras, na cena. Investigamos então outro caminho: ao invés de trazer o texto (e com ele a sua musicalidade, seus ritmos e movimentos), começamos a trazer a velha para a cena. Criamos a figura de uma mulher que iria atravessar toda a peça, sem contar a história dela como estava descrita neste texto inicial. Passamos a chamá-la de FIGURA MÍTICA.

\section{AMASSVELHA QUE OTEMPO}

TRANSFORMOU-SE NA

\section{FIGURA MÍTICA.}

Por esta época, Alencar já havia chegado ao sistemaprocesso, e experimentamos juntos: músicas, movimentos, sons, textos, para nos aproximar dessa figura, transformá-la em carne.

\section{Faixa 15}

\section{CADERNO DE RELATOS III}

(Relato de Renata Vendramin, 04 de outubro de 2013)
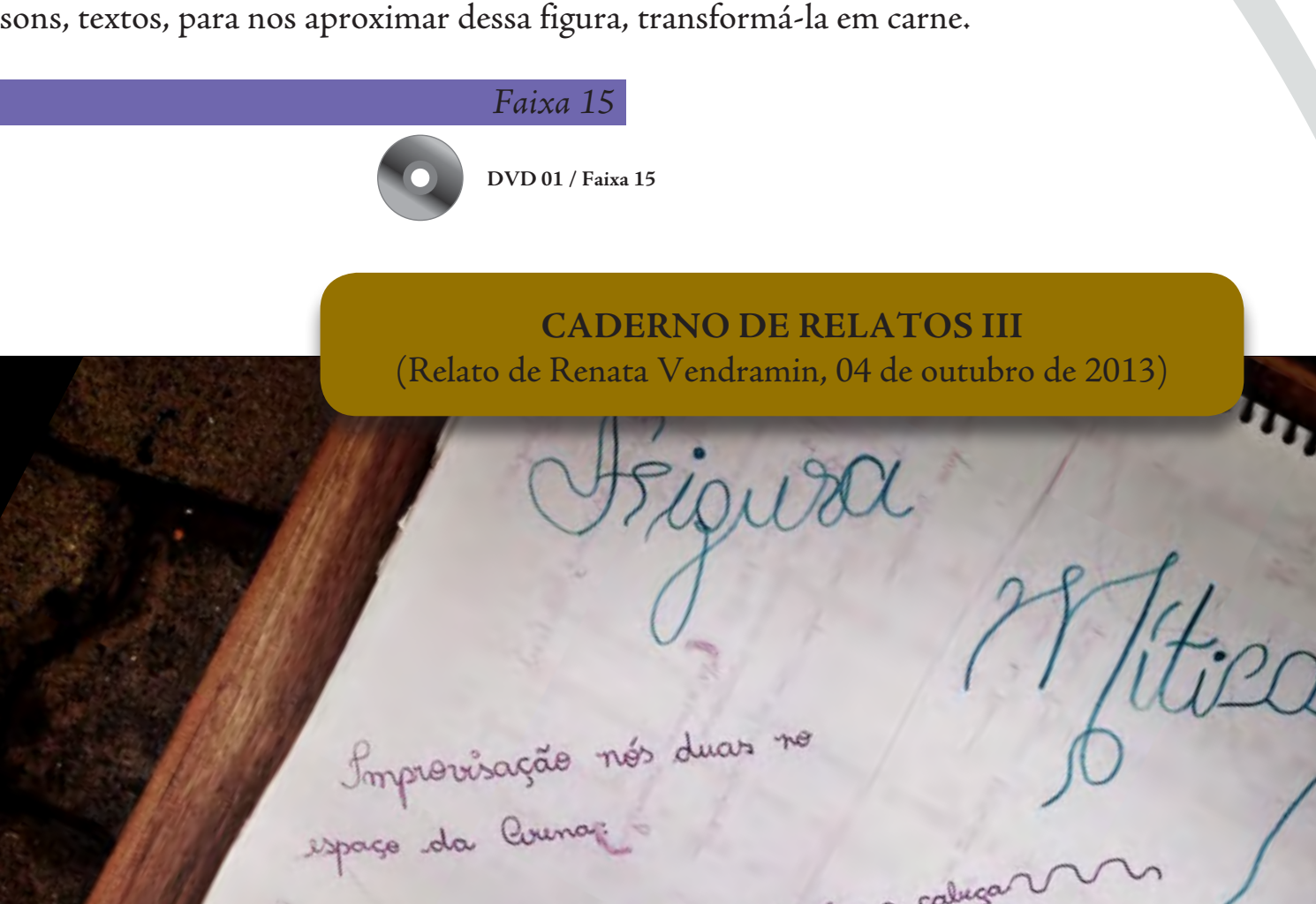
Na primeira organização da teia dramatúrgica que culminou na abertura de processo da peça em dezembro de 2013, a Figura Mítica iniciava, terminava e atravessava algumas vezes a peça mexendo com fios de linhas: puxando e desenrolando fios, desatando nós, cortando linhas. A cenógrafa, Lívia Loureiro, que integrava o sistemaprocesso, teceu um manto, em um tear, que cobria a cabeça da Figura Mítica. Janaína e eu nos revezávamos para fazê-la durante toda a peça.

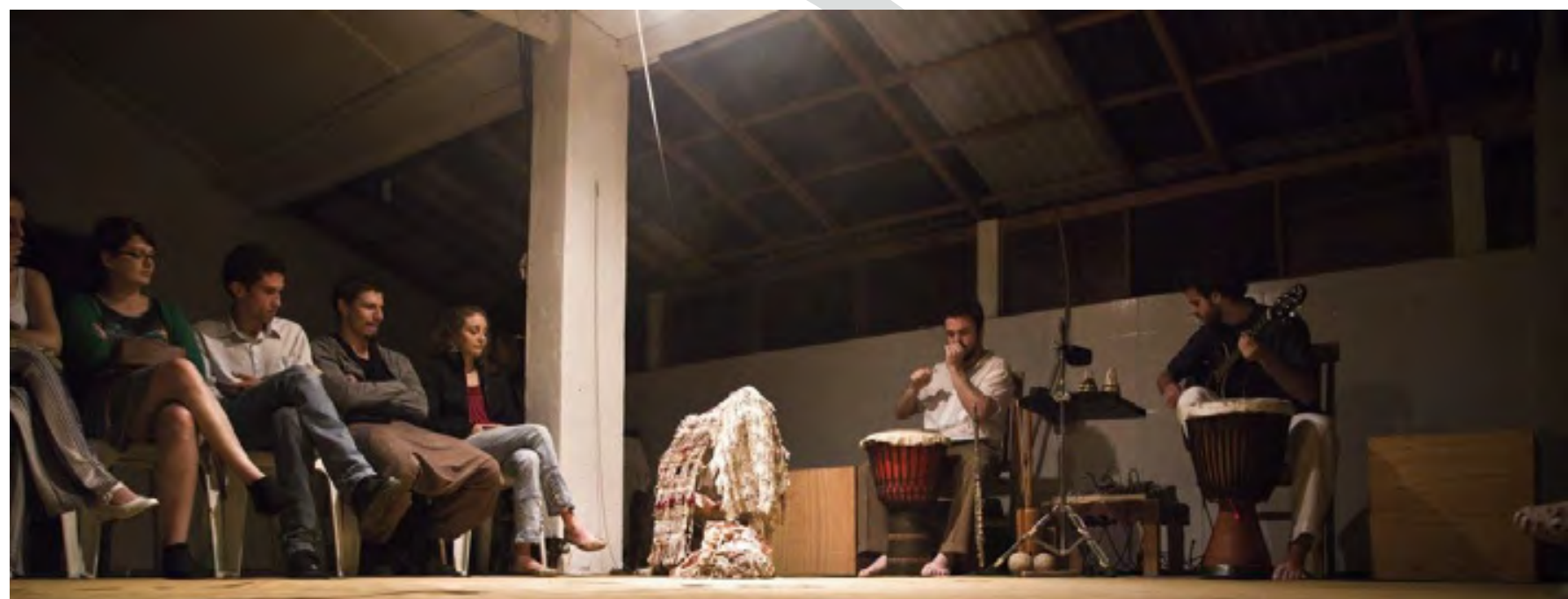

Figura 07. Abertura de processo da peça, dezembro de 2013. Foto: Tide Gugliano.

Para a célula inicial (Prólogo), que começava com a Figura Mítica, cocriamos outro texto mais sintético para apresentá-la ao público. Esse texto era narrado por Janaína em um microfone, enquanto eu, como Figura Mítica, atravessava a cena puxando um fio de linha no espaço:

As histórias, as palauras, os sons, os nomes, as fotografias, os ruídos, os gestos, ela recolhe. Desata os nós, alinhava. Tem a cor das fotografias mofadas, das roupas desbotadas, das coisas sem uso, dos padrões do nosso tempo. Tons desconhecidos pelos nossos olhos. Ela é memória, imaginação e atualidade. Ela anda assim, num sussurro constante. São os ecos do mundo falando nela. As vozes do mundo e o silêncio. Ela testemunha esse tempo, o que já foi e o que ainda virá. Quando nós chegamos, ela já estava e vai estar aqui quando a gente for. Ela guarda nos bolsos o inicio è o fim das linhas que formam a rede das nossas histórias. Tudo o que passa por esse mundo quintal, ela recolhe. Ela assopra os cantos de fatos empoeirados. Alinhava os fios da imaginação vislumbrada. Ela está. Ela transpassa as histórias, todas elas, no mesmo instante em que elas acontecem.

Agora mesmo, enquanto vivescrevemos o presente, ela passa e recolhe. Escuta...

Nos outros momentos em que ela aparecia, entre uma célula e outra e no final, existia uma sonoridade composta de ruídos vocais (inspirada na música da cantora Sainkho Namtchylak) e do som de uma tigela, ou ainda o silêncio. Em muitas experimentações e improvisos, descobrimos que, quando a nossa voz (minha e da Janaína) aparecia na cena, fragilizava o restante do corpo da figura que estávamos encarnando. A sonoridade, o timbre, a intensidade, a potência, a frequência, a vibração da voz da Figura Mítica não eram os da nossa voz. Experimentamos outros caminhos. 


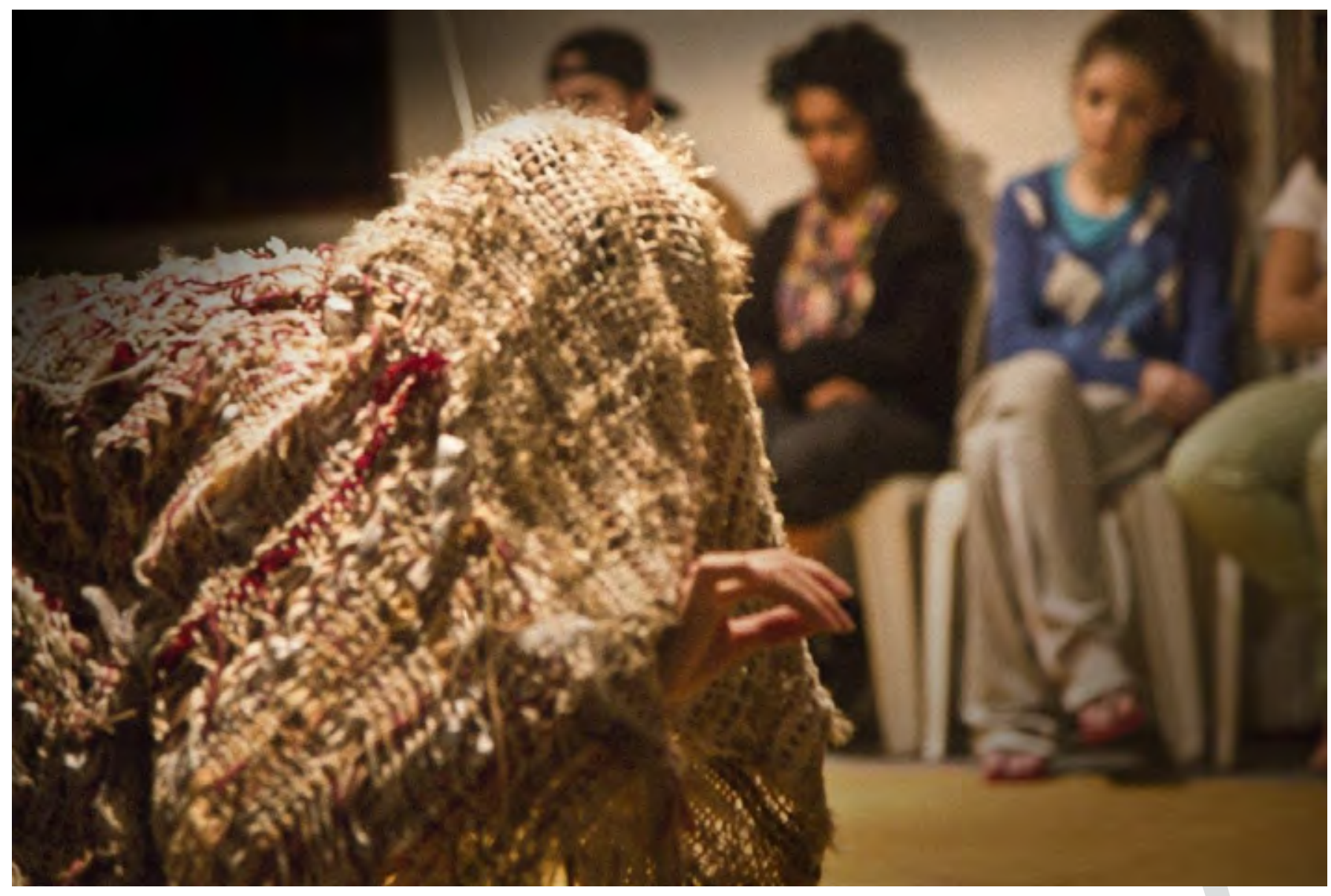

Figura 08. Abertura de processo da peça, dezembro de 2013. Foto: Tide Gugliano.

A abertura de processo, seguida de uma conversa para escutar a ressonância da peça no público, trouxe muitas reflexões sobre essa Figura, sobre como as pessoas a enxergavam e que sentidos ela encarnava. Um ponto muito importante foi que as pessoas estavam associando a imagem dessa mulher às moiras da mitologia grega, seres que determinavam o destino dos homens. No entanto, a Figura que estávamos construindo não decidia o destino das pessoas, não interferia na escolha delas; ela apenas recolhia as histórias e tecia a rede. E este era um ponto bastante relevante dentro da peça, precisávamos encontrar um caminho, modificar algo no texto, na figura, que deixasse claro que ela não era uma fiandeira de destinos.

Quando iniciamos o segundo ciclo do sistemaprocesso em 2014, uma coisa eu sabia intuitivamente: a Figura Mítica, ou todos os outros nomes que ela já teve e teria, deveria estar na peça, e para isso era preciso reencontrar o lugar dela e a maneira de encarná-la em cena. Retornei então à origem de tudo: ao texto de A Mais Velha que o Tempo. E neste reencontro surgiu a ideia de trazer uma MÁSCARA para a cena.

o primeiro pa-
radoxo fundamental
é que a verdadeira más-
cara representa a expres-
são de alguém não-masca-
rado. (BROOK,1994, $\quad \begin{aligned} & \text { Tenho comigo que a viagem para a Co- } \\ & \text { lômbia }{ }^{46}, \text { em que vi e comprei másca- } \\ & \text { ras belíssimas feitas por índios daquela } \\ & \text { região, objetos com presenças fortes, } \\ & \text { despertou-me esse desejo de experi- } \\ & \text { mentação. De Bogotá também trouxe a } \\ & \text { ocarina que utilizo; quando a vi, sabia } \\ & \text { que ela estaria na peça. Não sabia ainda } \\ & \text { em que momento, mas sabia que esta- } \\ & \text { ria. Confiei na minha intuição. }\end{aligned}$


Aproximei-me da máscara como sugere Brook, como quem quer se aproximar de algo, de alguém, de uma força. Eu sabia que A Mais Velha que o Tempo não poderia ter o meu rosto. No primeiro ciclo do sistemaprocesso havíamos escolhido cobrir as nossas cabeças com o manto, mas agora era outro momento, e estávamos em busca de elementos que nos permitissem encontrar a reorganização da peça neste novo ciclo.

Para o primeiro ensaio, improvisei uma máscara de papel sulfite, depois fui até a sala de adereços do Departamento de Artes Cênicas da ECA-USP e escolhi outra máscara de papel (a que julguei mais neutra e adequada que havia lá). A leitura do texto de Brook chamado A Máscara - saindo de nossas conchas, do livro O Ponto de Mudança, auxiliou-me muito para encontrar o caminho de relação com a máscara. Eu tive vontade de usá-la antes de ler este texto, e, quando me encontrei com a voz de Brook, algumas inquietaçóes, dúvidas e medos deram espaço a inspirações. Eu tive uma vontade genuína e uma necessidade de trazer uma máscara para a cena, mas como atriz trabalhei muito pouco com máscaras, não estudei técnicas específicas para usá-las em cena, e isso poderia ser um problema e um desrespeito à tradição, dependendo da relação que escolhesse estabelecer com a máscara.

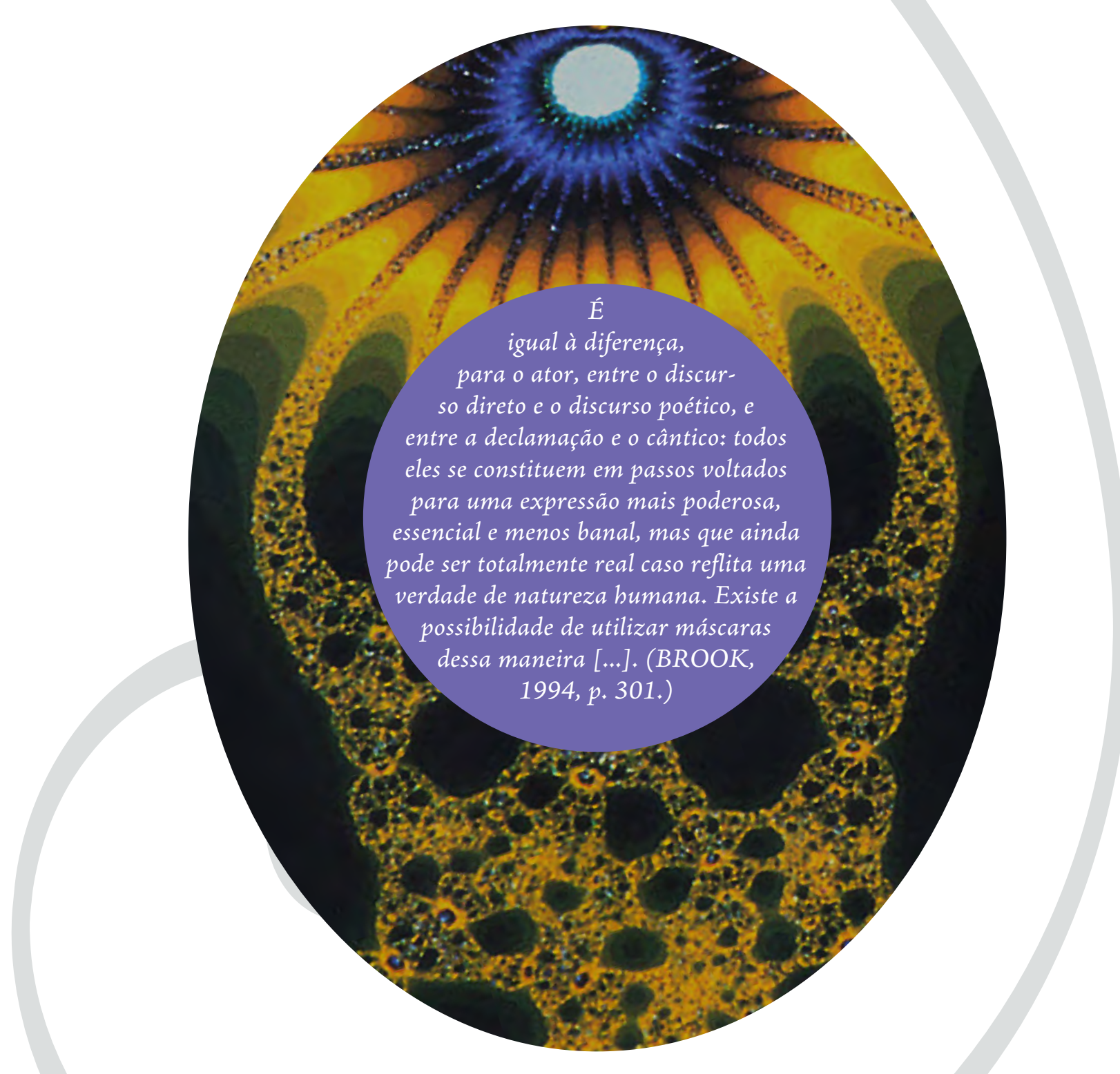

Outra conversa importante foi a que tive com uma das integrantes do CEPECA, Joana Barbosa, que estuda e pratica técnicas de trabalho com máscaras. Compartilhei que estava pensando em usar uma máscara na peça, e ela disse que provavelmente haveria de ser uma boa escolha, pois, segundo o que conhecia do trabalho que vínhamos fazendo, a maneira como trabalhávamos o corpovoz, deixava-o pronto para receber uma máscara.

Antes de habitar o espaçotempo de cocriação com a máscara, fiz uma primeira mescla dos textos A Mais Velha que o Tempo e Figura Mítica, lendo-os e encontrando possíveis entrelaçamentos entre um e outro. 
Q Mais velha que o tempor

(1)

Existe uma velha que vive num lugar oculto, de que todos salem, mas que paucos já viram.

Ela parece esperar que cheguem até ali pesseas que se perderam, que estäo vagando à procura da própria história.

Ela é circunspecta, quase sempre cabeluda e tem ancas largas Sus bigodes pressentem o futuro. Ela vaja simultaneamente para frente e para trás no tempo, equilibrando um lado com a dança que realiza com o outro. som tigela

Cis historias, as palavras, os sons, os nomes, as fotografias, os ruidos, as gestos, ela recolhe. Tem a cor das fotografias mofadas, das roupas desbotadas, das cousas sem uso, dos padröes do nosso tempo.ITem também tons e formas desconhecidas pelos nossos olhos Ela é memória, imagina ção atualidade. (EcOS)

Ela sabe crocitar/e cacarejar, sabe mais sons animais que humanos.

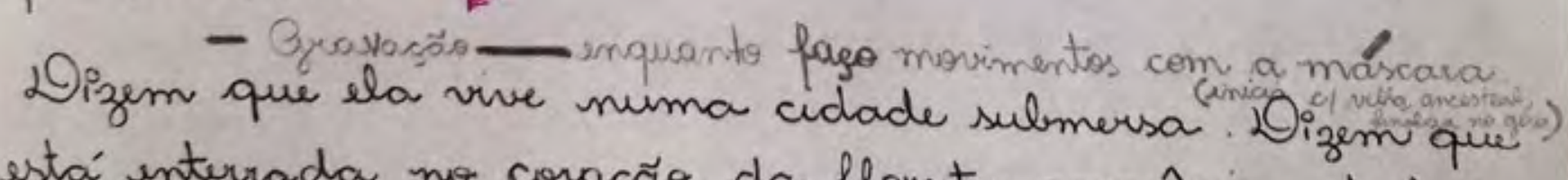
está interrada no coracão da floresta amazónica de baixo de uma samauma. Dizem que ela foi vista viajando pa ra o Sul, para as lataratas do Sguasu, num carro incen diade com a janela traseira arrancada. Digem que os pássaros the contam as marrativas de vida.

Lizem que ela fica parada na estrada perto de Coumbá,

125 
que pega carona aleatoriamente com caminhonevios ate (2) a Bolivia. Ouzem que é possivel senti-la entre o chacra cardíaco es chacra laríngeo na altura da segunda vértebra torácica. (Giro) gizos no calcanhar

Ela anda assim, num sussurro constante. Säo os ecos do mundo falando nela. Cs vozes do mundo e a silêncio. Ela testemunha usse tempo, o que já foi e o que ainda virá. TQuando nós chegamos, ela já estava e vai estar aqui quando a gente for.

Ela é conhecida por muitos nomes: A mais velha que otempo,

guardoñ do devir...

- Trunancestral

- únice trabalho da 'mais velha que otempo' e'tecer a rede de histórias. Sabe-se que ela recolhe e alinhava principalmente as que correm a risco de se perderem para a humanidade.

Sua caverna e' cheia de historias de todos as tipos: antigas, inventadas, ignoradas, reinventadas, vividas, esquecidas, rejeitadas, descontecidas, prenunciadas, imaginadas. Você sente ela recolhe, você vive ela recolhe, você Thistorias sä́o agina ela recolhe.

Todas alinhavadas uma a outra, diariamente, num sacro ofício, dia a dia, tecendo a rede de histórias. 
Thdo a que passa por isse mando quintat, eld recore (3) Ela assopra es cantos de fatos empoeivados. Cilinhava as fios La imaginaçáa vishumbradp. Ela está. Ela transpassa as históias, todas elas, no mesmo instante em que elas acontecem. Agora mesmo, enquanto VIVESCREVEMOS o presente, ela passa e recolthe. Escuta...

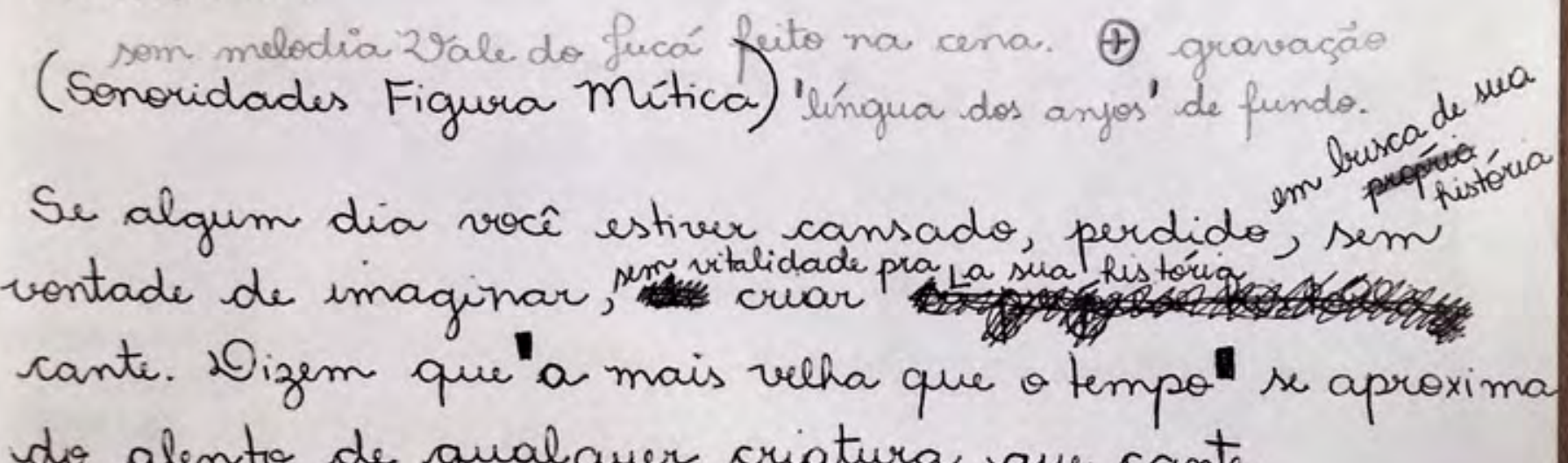
do alento de qualquer criatura que cante.

DANCCA $\rightarrow$ movimento AMVQT.

to If se en pudesse só por um segundo, rever os portotes do mundo que os avós criaram. To

Ans: tira gizos, máscana, deixa petto do vun ancestral que esta perto do banco. Wou me sentar perto do Alencar p/ cantar:

- Ecos do mundo

- Senta empoutro banco disponíul na borda do cículo p1 "Solucgés Inuíteis." Embaixo deste banco deixau o caderno da

- Pego o caderro comego cena intáncia infância)

- Praginamentos (danco?)

- A próxima história 
Com os textos entrelaçados, a máscara, a ocarina e os guizos comigo, fui para a cena. Nos exercícios e práticas de chegada e sensibilização do corpovoz, sentia cada vez mais a necessidade de trabalhar a voz em movimento, dançando pelo corpo, o movimento em som, deixando ressoar sons, sonoridades, músicas, falas, pelo espaçotempo. Aos poucos, habitando o espaçotempo de cocriação, suportando permanecer neste CAMPO DE FORÇAS, neste SiSTeMa NERVOSO, ainda guiada por impulsos e intuições amorfas ou pouco delineadas, em relação, a máscara e os outros elementos se integraram a mim, eu a eles, e nós ao texto. Os novos elementos se entrelaçaram à célula como se desde sempre já estivessem ali.

\section{CADERNO DE RELATOS IV}

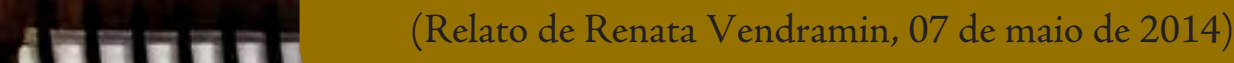

Ensaio em casa sozintra.

Máscara de papel sulfite.

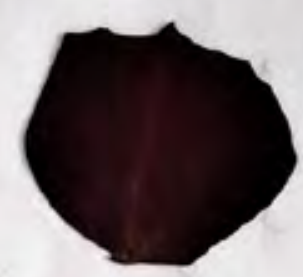

\section{$07 / 05 / 14$}

Prqueno Yamá

Textos AMVQT e da F.M misturados, entrulacyados, cortados, revistos, acrescentados.

Me relaciono of estes slementos.

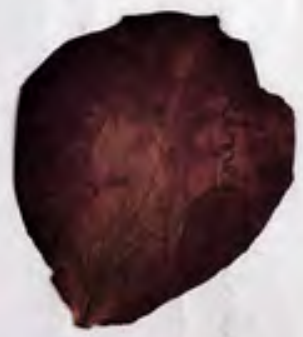

A Polifonia do texto se apresenta,

os movimentos saltam do papel, vibram o corpo. GRAVAÇÖES: gravar trechos do texto com a minha lez mesme pi compore al a minha vez dita na cena.

- Eiro las Evizos las cablew Anito

na cena, querem estar. Quere guizos indianos nos mus pús e cotocar or que temos no Alencar.

Tha relaças com texto modifice tudo aquilo que pode trazer a imagem das Moiras, do destino, a MV.QT é outre mito. Outra história. Ela é uma resposta poética, teatral a pergunta: se este mundo estivesse grávido de outro, como serva a outro mundo que vai 
Provavelmente porque ainda não era o momento de escutar e encarnar este passo. O sistemaprocesso é sábio. O som da ocarina e sua presença como elemento de cena soou, desde o princípio, muito harmônico com o todo que se delineava. O desenho que a ocarina tem, transformou-se em uma das imagens de A Mais Velha que o Tempo.

Nos ensaios com os novos elementos, relacionando-me com o texto da narrativa, alguns movimentos e qualidades de movimento que aconteciam em outras células da peça (como foi apresentado na abertura de processo em 2013), começaram a ser retomados, trazidos para esta célula. Por exemplo, o giro com guizos nos tornozelos, que relato no registro escrito acima. Este giro acontecia na célula $A$ Cabeleira de Anita, que não permaneceu na organização final da peça. Contudo neste movimento com guizos existem muitos sentidos que dizem respeito à peça como um todo, com a temática que estamos lidando, com nossa poética, então ele se sustentou, ele permaneceu, ele reencontrou o seu lugar na peça, de maneira orgânica.

No original do último texto de A Mais Velha que o Tempo (acima digitalizado), existe, no final, escrito à mão em tinta azul, um rabisco que sugere uma organização para as células da peça. Depois de uma manhã de ensaio sozinha, em relação com o texto entrelaçado e com os elementos máscara, ocarina e guizos, tive essa inspiração para a reorganização da dramaturgia, considerando aquilo que Alencar e eu escolhemos que deveria existir na peça neste novo ciclo. Eu a visualizei como um todo e já podia perceber nuances de atmosferas, vislumbrando transições de uma célula para a outra, movimentos meus e do Alencar.

Foi um fluxo criativo bastante inspirado e assertivo. A partir deste rascunho, encontramos o caminho de reorganização da dramaturgia cênica. Foi como se esse reencontro com A Mais Velha que o Tempo (e tudo a que ela se conecta) tivesse me possibilitado encontrar e organizar sentidos e semsentidos da teia dramatúrgica como um todo. E não foi uma organização somente racional, não pensei em sentidos específicos que pudessem ligar uma célula a outra, simplesmente anotei o que vinha à cabeça, e, ao olhar para a proposta, ela me pareceu bastante

\section{COERENTE, HLARMOANICA e SiSTêMiCa.}

Diferente do que acontecia na primeira organização da abertura de processo, nesta proposição conseguia sentir materializando-se a TEIADRAMATÚRGICA, podia perceber espaços abertos para a cocriação de sentidos e semsentidos para além das palavras, na música, no movimento, na relação entre uma célula e outra, na minha relação e do Alencar, na nossa relação com o público. No entanto, ainda era preciso experimentá-la na prática. Escolhi, neste dia de ensaio, apresentar para o CEPECA essa nova organização para poder sentir como ressoava no público. Começamos a trabalhar para isso.

\section{Faixa 16}

Os movimentos surgiam meio desajeitados, ainda sem o tônus e a energia que, de fato, podem encarnar... No milagre do trabalho, da disciplina, do dar-se tempo e espaço, do fazer e refazer, aos poucos as formas ganharam contornos. Paciência, gentileza, escuta, delicadeza, com as formasgirinosrecemparidas, elas foram ganhando corpovoz e limites mais definidos na ação de fazer, no ganhar experiência... assentando-se, encarnando.

No dia 05 de junho de 2014, fomos então para o encontro com o outro, no CEPECA. 


\section{Lege ol o sagrade/brijeve. (entrelaçar mais)}

CADERNO DE RELATOS IV

(Relato de Renata Vendramin, 05 de junho de 2014)

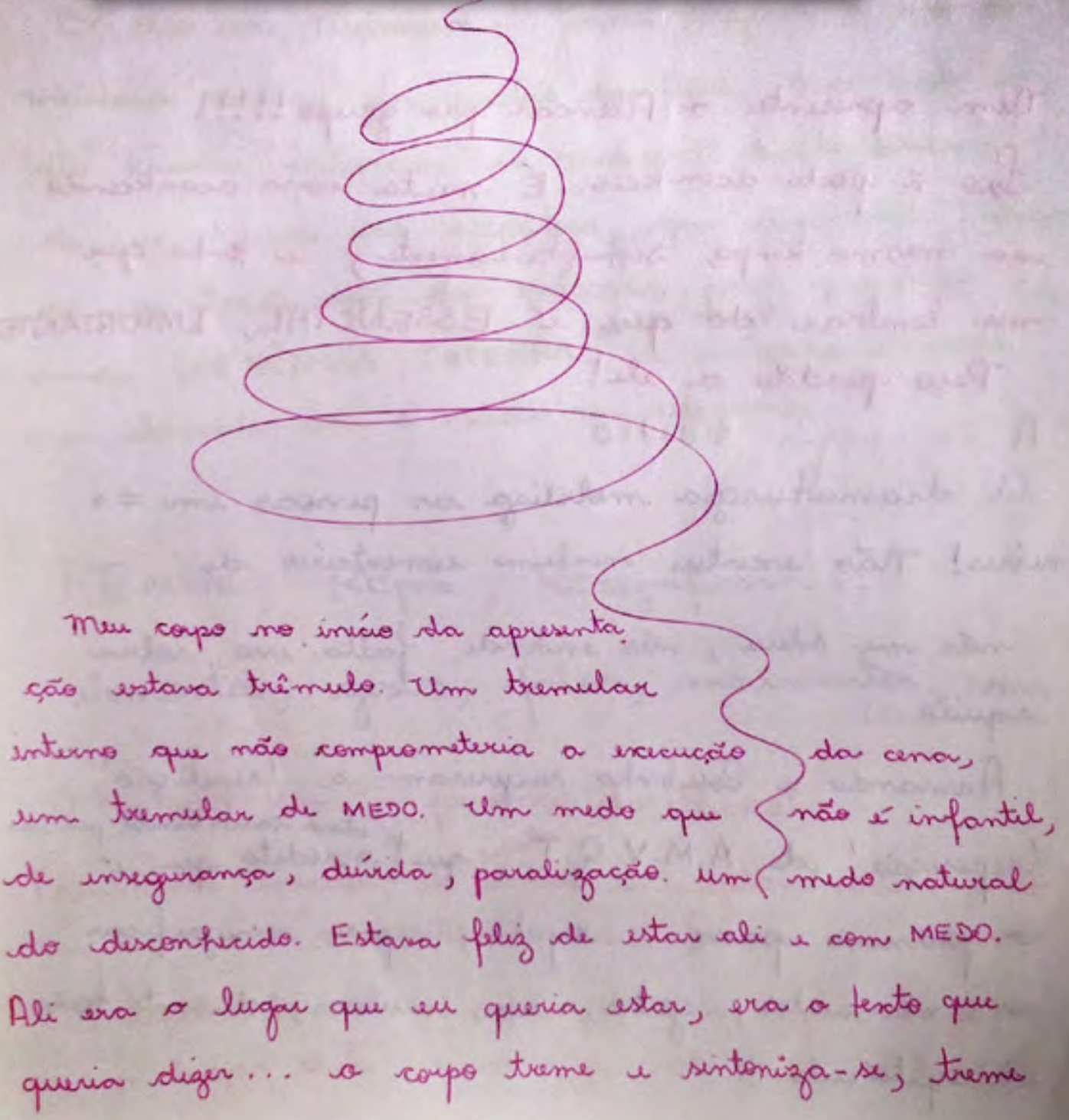

Após compartilhar no CEPECA, em que os elementos que trouxemos para a cena (máscara, ocarina, guizos) tiveram uma ressonância interessante nas pessoas, ampliando os sentidos desta célula, Alencar e eu botamos atenção nas músicas, sons e sonoridades. Da mesma maneira que no primeiro ciclo, sabíamos que a minha voz fragilizava a figura de A Mais Velha que o Tempo; portanto, quando ela encarnasse durante a narrativa, não seria a minha voz que iria compor a musicalidade que os movimentos da velha desejavam; quando realizava os movimentos da velha, ouvia sons no espaçotempo... Ainda não sabia se era o tambor, o maracá, o som da tigela sonora, o berimbau tocado com o arco da rabeca, ou tudo junto. Maturando as ideias e sensações da célula com o Alencar, ele propôs de trazer uma gravação feita com o toque de tambor, o som da tigela e o berimbau tocado com o arco da rabeca (todos esses instrumentos foram investigados e usados bastante durante o primeiro ciclo).

Antes do compartilhar no CEPECA, havíamos reconhecido que trabalhar com a minha voz em off, gravada, não seria o recurso que traria a POLIFONIA que queríamos. No entanto, o recurso da gravação ainda era considerado, posto que Alencar não daria conta de executar vários instrumentos musicais ao mesmo tempo, e, em alguns momentos da peça, como nesta célula, ouvíamos mais de um instrumento ressoando no espaçotempo de cocriação.

Alencar apresentou uma primeira proposta de música gravada para os momentos em que A Mais Velha que o Tempo encarnava na célula. A música trazia a atmosfera sentida, mas precisamos ainda ajustar o ritmo dela com 
os movimentos corporaisvocais da Figura. Sentia que a música precisava ter um crescente em intensidade, em saturação, em volume. Fomos nos relacionando e juntos afinando estes detalhes: os movimentos do meu corpovoz ajustando o ritmo da música, a música modelando os movimentos do meu corpovoz, Alencar se relacionando com as minhas propostas de movimentos, eu me relacionando com as propostas de músicas do Alencar. Quando definimos as propostas de músicas gravadas para cada momento da célula, foi necessário então praticar o "dar o play". Parece um detalhe banal e irrelevante, mas não é. Os momentos do "play" das músicas são movimentos de P A S S A G E M, de mudança de atmosfera, de qualidade de movimentos corporaisvocais; sendo assim, precisam ser precisos e sutis, ao mesmo tempo. Precisávamos R E S P I R A R JUNTOS, Alencar e eu, até porque o tempo de duração da música e dos movimentos de A Mais Velha que o Tempo não foram marcados (por escolha), eles variavam, podiam estender-se, sintetizar-se, dependendo do encontro do dia. Para afinar nossa relação, respirar ansiedades, atropelos, praticamos juntos... Respiramos juntos a célula e seus movimentos, suando a ideia de que

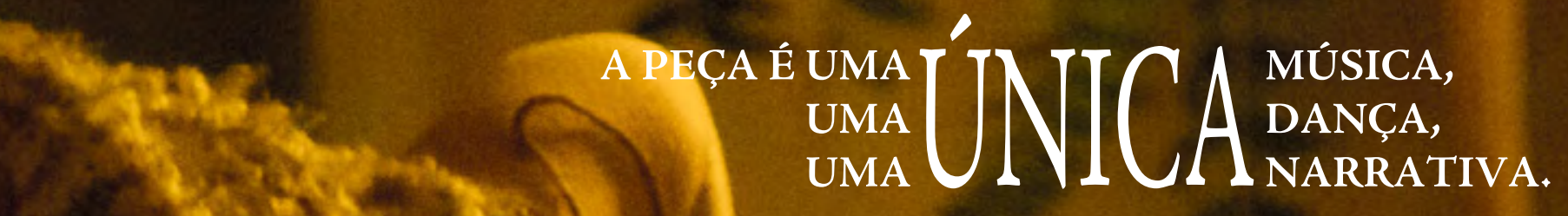

Ao trabalhar cada detalhe da célula, seja da música, de movimentos corporaisvocais, da iluminação, do figurino, sempre retrabalhava o texto da narrativa. Frases, palavras, trechos do textopalavras também estavam se movendo, experimentando diferentes combinaçóes de ordem, de cortes e ampliação do que estava sendo dito. Assim, a dramaturgia de...

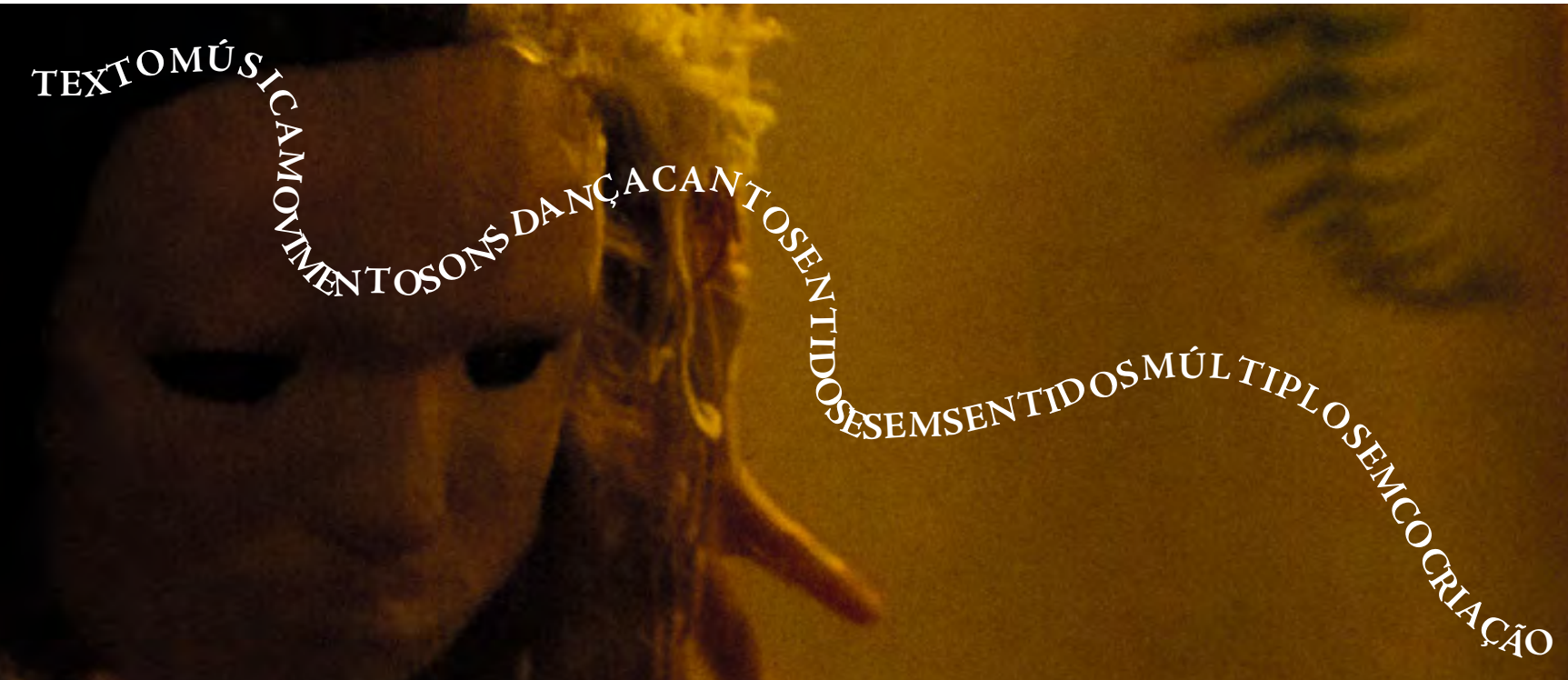
... foi ganhando forma. Chegamos, então, à versão final da teia dra- matúrgica desta célula:

Considero que esta célula e a Infância ${ }^{47}$ são as que têm o mais alto grau de cocriação e entrelaçamento. Desde o início de suas feituras, quando a primeira semente de inspiração brotou em uma de nós, ela foi compartilhada e gestada por todas as artistascocriadoras. A in-

${ }^{47}$ Entrelaçamento com o texto da página 150. 
tenção é que cada vez mais estejamos conscientes desta prática, dando-nos tempo e espaço para que ela aconteça em fluxo e ritmo criativos; afinal, a TEIADRAMATÚRGICA (que é a peça) é uma ressonância do sistemaprocesso de cocriação vividos durante todo o trabalho, é...

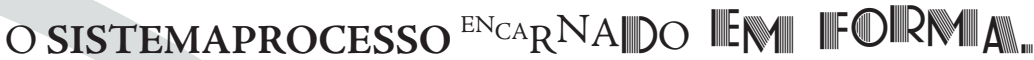

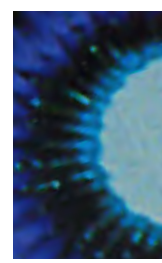

\section{CÉLULA 3-ECOSDO MUNDO}

Nas tentativas para encontrar um novo caminho para a dramaturgia cênica depois da abertura de processo em dezembro de 2013, surgiu a ideiasemente da música que compóe a célula 3. Com a decisão de tirar a Figura Mítica da peça, ela que iniciava e finalizava nossa experiência, precisávamos tecer outro começo. Consensualmente pensamos (nos poucos ensaios que tivemos após a abertura de processo, antes de encerrar o primeiro ciclo) em uma músicanarrativa que nos inserisse no universo da peça e desse o tom da experiência teatral. Janaína disse que ficaria responsável por trazer uma proposta.

PRIMEIRO PARTO:

Ao ouvir a música trazida por Janaína ao espaçotempo de cocriação, ressoou em mim um pensamento recorrente, que constantemente eu retomava em nossos encontros e proposições: a meu ver, a música convocava somente o universo da origem passada, do antes, da memória, da trajetória percorrida, que também compõe a peça, mas não só este universo. Precisávamos trazer mais a instância da atualidade e da imaginação. Ainda mais neste momento, depois da abertura de processo, em que revíamos muita coisa da peça a partir da ressonância que sentimos no público. A peça é sobre origens:

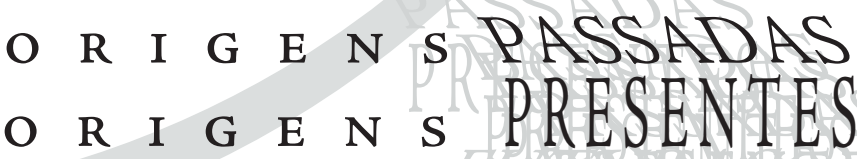


A peça nos convida a olhar para as nossas origens, para os nossos prOCesSOs dE O R I G E M, de como a gente se cria e recria-se constantemente, convida-nos a reconhecer os nossos $\mathrm{P}^{\mathrm{A}} \mathrm{DR}{ }^{\mathrm{O} E} \mathrm{~S}$ DE COCRIAÇÃO De $M U N D O S$. E muitas vezes em nossas propostas criativas prevalecia uma atmosfera quase nostálgica, confortante e perigosa de relação com as origens passadas e a memória. Para mim ainda não era isso, apesar de ter gostado da melodia e de muita coisa que estava sendo dita e encarnada na música. Sentia que a música precisava expandir-se um pouco mais...

SEGUNDO PARTO:

Faixa 19

DVD 02 / Faixa 19

\section{CADERNO DE RELATOS IV ${ }^{48}$}

(Relato de Renata Vendramin, 10 de dezembro de 2013)

\section{Múseca trúcio}

$10 / 12 / 13$

E se a gente pudesse destampar as vozes do mundo

Do antas, do antes, de antes. je outro

Que dizem dela, de mim de nós

E se a gente pudesse refazer ia trama de historias

De antes, do hog, de agora

Fios que se (encontram, atra vessam, ruzam) Nós.

E se a gente pudesse escutar os siléncios de histórias sementes, ainda latentes, no ventre ב̈.

\section{4haly}

10. Nón. Nós. Has tear

E se a gente pudesse pegar nas

máos as flos

Que seria de Nós?

Thu seriari dos Nós?

Ese a gente pudesse, num facho de lug,

olhar nos olhos do tempo

que guarda os ecos do mundo

10 (presente, passedo, furtivo)

(1) que perguntaria?

${ }^{48}$ Os detalhes e correções em caneta cor de rosa no texto já dizem respeito às modificações que fiz durante o segundo ciclo do processo em 2014. 
Compartilhei com Janaína, e a impressão que ela teve era de que a música era etérea demais, acreditava que precisávamos de alguma música com uma qualidade mais telúrica para iniciar a trajetória da peça. Experimentamos algumas vezes as duas proposições de músicas com os músicos que estavam conosco no sistemaprocesso; eles ainda não conseguiam dizer, naquele momento, qual das duas era mais coerente, harmônica, condizente com a ressonância que buscávamos, ou se seria ainda uma nova proposição. Logo em seguida encerramos os trabalhos do primeiro ciclo.

Essa música foi a última cocriação que fizemos antes de encerrar o primeiro ciclo, portanto ela estava muito pulsante e repleta de sentidos para mim quando iniciamos o segundo ciclo e começamos a fazer algumas escolhas. Retomamos o trabalho com ela, Alencar e eu, antes de viajarmos para a Colômbia a fim de participar do projeto Inter-Câmbios América Latina, do CEPECA. Junto com a oficina, preparamos um material artístico para compartilhar com os participantes. Decidimos trabalhar com uma das narrativas da célula 5 (Infância) e com essa música que passei a chamar de Ecos do Mundo.

Acabamos, por fim, compartilhando apenas a música Ecos do Mundo com o grupo no final da oficina e, a partir dessa experiência, percebendo a ressonância da canção em pessoas que falampensamsentemexistem em outro idioma, sentimos que a música estaria na peça.

prop. ion

CADERNO DE RELATOS IV

(Relato de Renata Vendramin, 28 de fevereiro de 2014)

Depois do exercicio da palavra, Alencar e un demos de presente ao grupo a música "Ecos do mundo", no flunco do encontro, sem prepará-los verbalmente ps a que iríamos fazer. Foi muito especial! Eles compreenderam as palawras, ressoou no coraçäe. Foi bem importante pentir como a música as sensibilizou, oppenta derigóes e inspiracjess $p_{1}$ as mudificacjes/escolhas do experimento cínico. A música toca de uma maneira universal?

Fico muito filiz e rerigorada com a desafio e a experiencia dessa oficina e dessa viagem! Como se a chama interna tírsse ganhado forca, una

Nos nossos primeiros ensaios do segundo ciclo, junto com a chegada e despertar do corpovoz para o trabalho, Alencar e eu sempre trazíamos a música, deixando-a SATURAR o espaçotempo de cocriação, para criar e recriar sentidos e semsentidos na relação com a gente. Quando a nova organização da dramaturgia se materializou, a música estava presente e nosso trabalho, a partir daí, foi permitir que ela ganhasse... 


\section{CONTORNOS MAIS RAPSÓDICOS

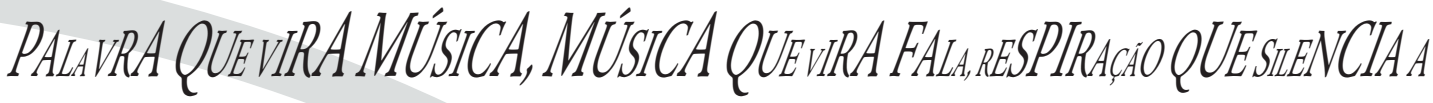

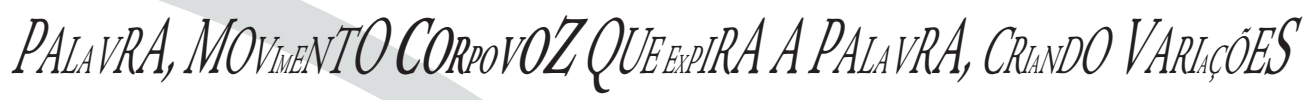 RITWCAS, DETONS, NUANCES ENTREA FALLCANTADA EO CANTOFALADO...}

Chegamos a pensar se seria o caso de compor uma melodia fixa para a música, mas reconhecemos que ela precisava de uma MALEABILID ADE, umaFLEXIBILIDADE, um FLUXOque era outro, que seria determinado a cada dia, quando Alencar e eu respirássemos juntos para cocriá-la no encontro. Experimentamos ainda trazer outros instrumentos para compor junto com o violão, como o berimbau, mas não pareceu coerente. Era mais simples!

Passamos então a experimentar voz e violão improvisados. Começamos a descobrir, eu na voz e Alencar no violão, quais seriam as nuances, variações de ritmos, tons, atmosferas da música. Em um determinado momento, solicitei que Alencar também cantasse junto comigo, mas o diálogo violão e duas vozes também pareceu excessivo e desnecessário. A relação vozvioláosilêncio soava mais interessante.

\section{Faixa 20}

DVD 02 / Faixa 20

Feita a escolha de que seria a minha voz e o violão: fizemos, refizemos, fizemos, refizemos e fomos cada vez mais

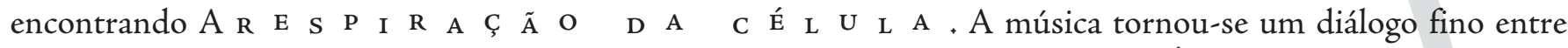
Alencar e mim, em que é necessário uma ESCUTA aberta para compormos juntos. À medida que exercitamos a nossa relação, o respirar juntos, fomos descobrindo os espaços onde era possível expandir a minha respiração e a respiração da música. Silêncios apareceram, palavras se encompridaram, outras se encurtaram, algumas viraram palavras faladas simplesmente, algumas frases viraram uma mistura de palavra falada e cantada... Os contornos rapsódicos encarnaram à medida que respiramos juntos: a respiração do encontro, que não é a minha, não é a do Alencar, não é a da cena, não é a do público, mas nasce da nossa relação.

R E S P I R A M O S JUNTOS.

O que acontece agora em cena, a cada encontro teatral, é que temos um IDESENHO RAPSÓDICO rascunhado, e vamos juntos respirando e brincando com esses contornos definidos, ele no instrumento e eu na voz. Reconhecemos que existe uma atmosfera trazida pela música e variamos as suas nuances de acordo com a relação, a respiração e o encontro do dia.

Um último desejo em relação à música foi o de subir o tom da minha voz, pois, da maneira como estava fazendo, a voz chegava a um grave que nos conduzia para uma atmosfera de regióes muito telúricas. Eu acreditava que a voz deveria ser um pouco mais solar para compor junto com todos os outros elementos da célula. Fui para a experimentação:

\section{Faixa 21}

9 A palavra rapsódia, rapsoda e todas as demais que se desdobraram a partir delas, encarnaram no sistemaprocesso quando cursei a disciplina "Linguagem, Experiência e Memória: Poéticas da Voz do Narrador e do Cantor como Sujeitos do Ator", no primeiro semestre de 2013, ministrada pelo Prof. Dr. José Batista Dal Farra Martins, no Departamento de Artes Cênicas da ECA-USP. Nesta disciplina, aproximamo-nos de textos teóricos e práticas que nos permitiram vivenciar e refletir sobre a experiência da "rapsoda contemporânea”, a artista que está entre a narradora (sujeita do épico, da ação, do ritmo, da informação, do público) e a cantora (sujeita do lírico, da paixão, da ressonância, do privado). Muito do que dialogamos, refletimos e experienciamos ressoou na prática e escrita da minha pesquisaexperiência, e muito da minha pesquisaexperiência ganhou eco nas aulas. Entrelaçamento com o texto da página 137. 
Repito, repito, repito... experimentando a repetição como um constante ciclo de morte e renascimento. Repito, experimento, pratico, para encontrar outro tom, para ressoar a voz em outros espaços do corpo, encontrar outra respiração, outra presença. Neste caso, como a intenção era subir um tom, eu precisava abrir espaços em regiões mais altas do corpo para a voz ressoar e, ao mesmo tempo, nas regióes mais baixas para dar apoio e sustentação para essa subida.

$\mathrm{Na}$ experimentação, relaciono-me com a minha voz e com a música a fim de descobrir qual o MOVIMENTO InTERNO dA R E S P I R A Ç Á O para cantar deste outro jeito que desejeiintuí. Com a experiência, aos poucos, a intenção é cantar com o esforço necessário, sem energia a mais ou a menos, com o tônus justo, e para isso: faço, experimento, exponho-me no espaçotempo de cocriação para sentir essa nova...

\section{DANÇA I $I_{N}$ TERNA DA}

A maneira como conduzimos nossa prática corporalvocal consiste na abertura de espaços nas regióes do corpo, no relaxamento de esforços desnecessários, no encontro com um estado de PASSIVIDADE CЯIATIVA, em que o corpovoz se coloca disponível em todo o seu fluxo, ritmo e habilidades possíveis para encarnar as cocriações vislumbradasintuídasdesejadas. Libertando-se do "querer fazer" para "fazer". Deslocando a energia do "querer fazer" para "o fazer", e, dessa maneira, concentrando a energia e usando-a de maneira mais inteligente e efetiva. Ao invés de ir em direção a uma forma ou padrão corporalvocal, abrimo-nos em escuta para encarnar as manifestações possíveis de ganharem vida em nosso corpovoz.

Além das práticas constantes e repetidas de alguns exercícios para abertura de espaços no corpovoz, também abríamos espaços relacionando-nos com outras vozes cantorasnarradorasrapsodas lançadas no espaçotempo de cocriação. Escutamos vozes, experimentamos cantar as músicas que essas vozes encarnavam na intenção de abrir espaços. A maioria das vozes era feminina, chegando para abrir espaços $\mathbb{Y} \mathfrak{N}$. Algumas delas foram:

\section{CÁTIA DE FRANÇA}

\section{DÉA TRANCOSO}

SAINKHO NAMTCHLAKY

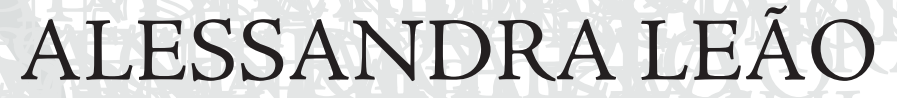

RENATA ROSA

\section{SIBA}

\section{Faixa $22^{50}$}

DVD 02 / Faixa 22

Exercitamos a ${ }_{\mathrm{E}} \mathrm{SCU} T \mathrm{~A}$ dessas vozes e a relação com as músicas encarnadas por elas. Abrimos espaços desconhecidos ou pouco habitados no corpovoz através delas, saturamo-nos a ponto de muitas sonoridades, sons e músicas da peça serem ressonância dessas QUALIDADES vOCAIS que escutamos. Em alguns casos, como na música Vale do Jucá, cantarolo a sua melodia no trânsito entre uma célula e outra. Em outros, a ressonância é mais sutil, está presente nas experimentações vocais, na maneira de compor a musicalidade das células, nas frequências acessadas, mas certamente esse CAmPO De S O N O R I D A D E S está presente em cada um dos sons, músicas e atmosferas cocriados na peça. 
Depois da estreia e micro temporada da peça realizada em novembro de 2014, assistindo aos vídeos desta célula, percebi que estava respirando muito pela boca enquanto cantava a música. A partir dessa percepção, estou mais atenta para equilibrar a respiração pela boca e pelo nariz, e respirando nas regiões mais baixas do corpo na inspiração.

\section{SIGO COCRIANDO, EM E $\mathrm{X}$ PERI ${ }^{\hat{E} N C I A}$.}

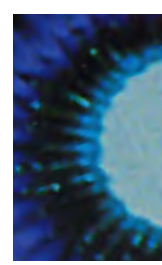

\section{CÉLULA廿-SOLUÇÕ̂SINÚtRIS}

Uma qualidade de texto que nos interessava entrelaçar à teia dramatúrgica da peça era o texto em primeira pessoa, narrado para o público, texto que chamamos de depoimento ou rapsódia, ou ainda DEPOIMENTO RAPSÓDICO.

A intenção era partir de nós, seja através de uma narrativa ou fato verídico, ou ainda de uma opinião sobre algum acontecimento da atualidade, e a partir daí trazer atmosferas, sentimentos, sentidos, reflexóes que expandissem as questóes levantadas no microcosmo para o macrocosmo ou também o caminho inverso, do macro para o micro. Partíamos normalmente de situações verídicas, mas não tínhamos compromisso com nenhuma versão do fato, fabulávamos à vontade para conseguir partir do EU e chegar ao NÓS. Ou ainda, partir do cotidiano, de situaçóes banais, e chegar ao poético.

Algumas vezes criamos figuraspersonagens a partir do depoimento de outras pessoas. Essas figuras também contavam suas narrativas, emitiam opinião sobre algum assunto ou fato e assim traziam mais uma voz, um ponto de vista, sobre as questões que mergulhávamos na peça. Em cena, esses depoimentos também eram ditos por nós em primeira pessoa.

A ideia era justamente que não ficasse claro o que era depoimento verídico, o que era fictício, o que era memória, o que era imaginação, o que era meu ou da Janaína... era uma REDE De voZES, uma PLuRA $\mathrm{F}^{\mathrm{EST}} \mathrm{A}^{\mathrm{A}}$ saturando o nosso espaçotempo de cocriação...

A palavra RAPSÓDIA ${ }^{51}$ encarnou no sistemaprocesso para dar conta deste textofaladocantadodançado que queríamos encarnar. Palavrasmovimentos que seguem o fluxo de cocriação da RAPSODA (essa rapsoda contemporânea), que parte do microcosmo e chega ao macrocosmo, variando ritmos, tons, cores, atmosferas. Um texto que dança no corpo da rapsoda, um textocorpo que dança encarnado em sons, sonoridades e músicas no espaçotempo de cocriação. 


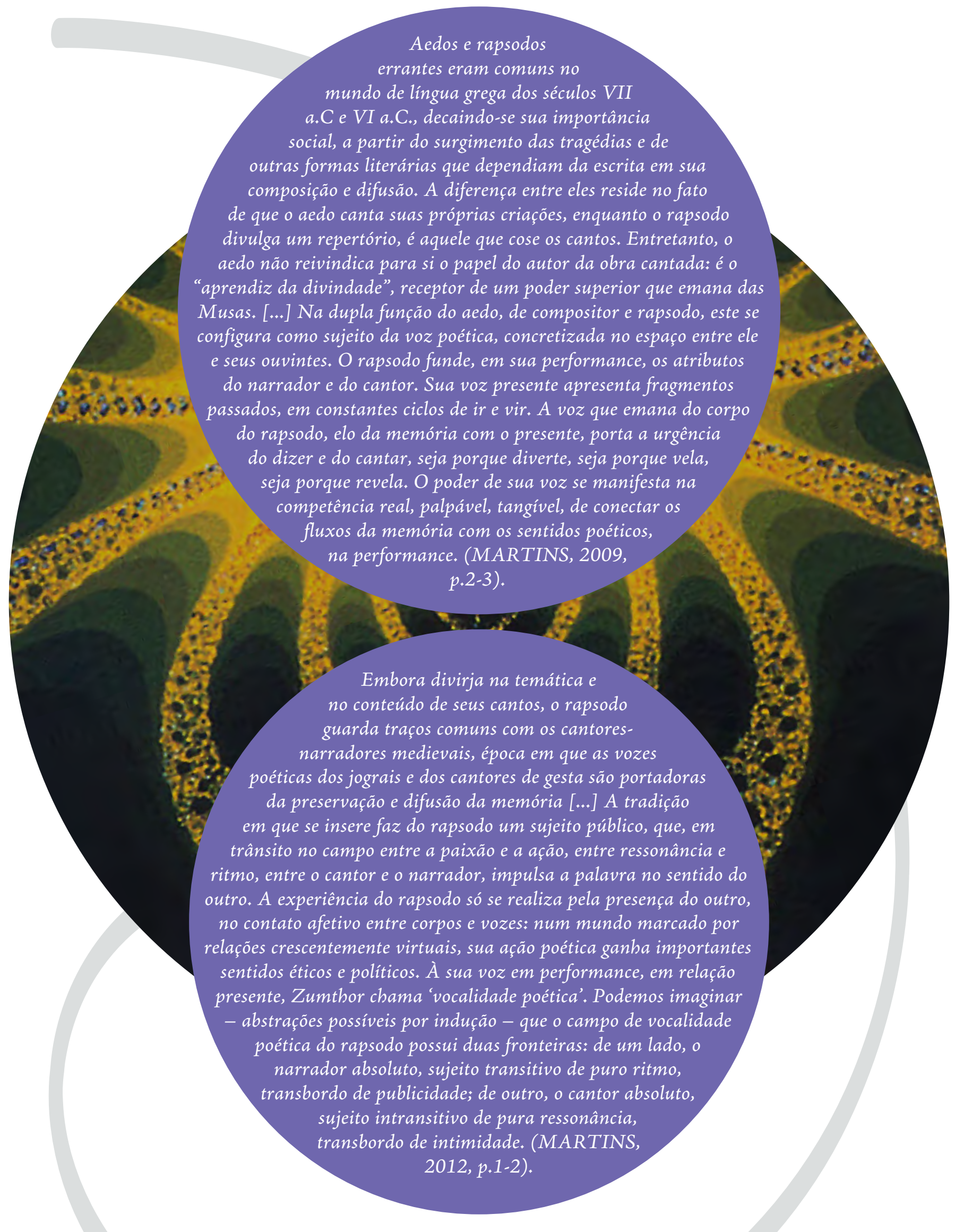

Investigações de depoimentos rapsódicos:

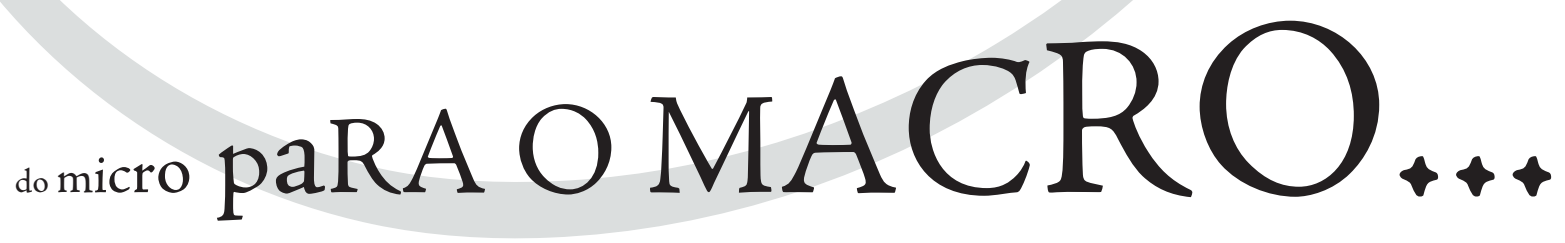




\section{Janaina: 1, 2, 3 e rodando. Take 7 - Comercial DEPOIMENTOS. (Bate palma pra fazer a claquete).}

Renata: Eu nasci em Paranavaí no Paraná. Aos 16 anos sai da cidadezinha do interior e fui pra capital estudar e conhecer o mundo. Estudei jornalismo mas não era o que eu queria pra minha vida. Comecei a fazer teatro. Curitiba ficou pequena pra mim. Vim pra São Paulo, sozinha. Sem familia, sem amigos, pra ganhar a vida. (espasmos I, começa mais miúdo, depois se intensifica) Eu nasci dentro do padrão, de beleza. (espasmos 2) Branca, saudável, olhos verdes, magra, nariz arrebitado que nem precisou de plástica. Só falta colocar um silicone no peito e uma progressiva no cabelo que fica perfeito. Perfeito pra que? (espasmos 4) Escolhi ser atriz. (lucidez) $O$ mundo esperava que eu celebrasse o padrão. Que eu alimentasse e reproduzisse o padrão. Vendesse o padrão escolhido, o padrão que promete sucesso, poder, fama. Me libertar da vaidade e das promessas redentoras não é tarefa simples... eu busco o meu padrão, eu busco outras possibilidades, eu sou a minha beleza, eu gosto de ver a beleza do outro. (espasmo 5) Esta é a minha história, e ela está sendo vivescrita neste momento, no meu ato de fala... não tá pronta, não... Onde é que a gente está enfiando a nossa história? À serviço de quê? lespasmos 6, o fogo da lucidez se apaga) Este é a minha vida. Este é meu mundo. Texnel é rádio, é celular, é ilimitada.

\section{Janaína: Corta! Valeu! Lindo!}

Transitamos por assuntos muito diversos, pois a escolha dependia do fluxo criativo das rapsodas - neste caso, Janaína e eu. Às vezes os depoimentos tinham relação com outras células da peça, aconteciam antes ou depois delas, contrapondo, complementando, ajudando a problematizar as questões trazidas, outras vezes apresentavam novas questões e estabeleciam relações mais sutis com as demais células.
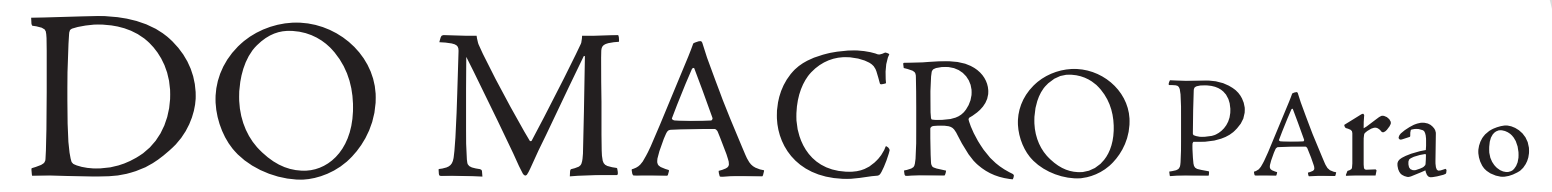

micro...

\section{DEPOIMENTO EU SOU FULANO DE TAL GUARANI KAIOWÁ}

\section{(escrito por Janaína Silva)}

Oi. Me procura nọ face. Eu sou fulano Guarani Kaiowá de tal. Acabou o fantástico. E falou-exaltou a novela, sensacionalizou a violência em São Paulo, falou raso bem raso da prostituição, do tráfico de drogas... explorou profundamente a vida da nova celebridade. E nada, nadinha mesmo se falou da situação nada, nada, nada nova das tribos indígenas do país, dos Guarani Kaiowá no Mato Grosso do Sul. Não é surpresa o porquê disso. Pra mim não. Pros amigos daqui do nosso pequeno mundo virtual certamente também não seja. A gente joga no Google e logo acha o mundo real. Um fragmento de notícia num site aqui, numa revista um pouco mais confiável ali. Daí a gente compartilha no facebook e se sente um pouco mais agindo. Eu sou fulano Guarani Kaiowá de tal! Mas aí eu pensei nos meus. A minha avó assiste tevê o dia inteiro. A noite vai pra igreja e reza, reza, reza, reza. Reza pra todo mundo que ela vê sendo notícia na tevê. Nem no jornal que ela vê e nem o pastor que ela ouve vão contar pra minha avó o que tá acontecendo e acontece faz tempo... Renata começa a vestir o casaco de Osvaldo, personagem da cena seguinte). Faz tempo... Faz tempo... Faz tempo? Faz quanto tempo? Quanto tempo faz que estamos aqui? Faz tempo... acontece faz tempo no nosso país e reflete muito do nosso comportamento.

Daí que eu peguei o telefone e dei a notícia. "Minha vó, a senhora por favor inclua os índios na sua reza! Que dessa parte de nós a tevê não fala. Essa parte de nós não interessa no jornal." A minha tataravó Sebastiana da Silva era índia. E a vó, da vó, da vó de muitos de nós também. Pensei que lembrar desse tipo de mistura é mais urgente nesses tempos do que acabar misturando a vida em desimportâncias. Do que acabar misturando os assuntos e acabar achando que essa história dos Kaiowá é coisa lá dos índios... 
Em um determinado momento do sistemaprocesso, embrenhadas no estudo coletivo do livro O Ponto de $\mathrm{Mu}$ tação, de Fritjof Capra, com o corpovoz fazendo inúmeras conexóessinapsesebulições (pois a leitura de Capra ativa uma consciência sistêmica), decidimos escolher algumas questóes lançadas pelo autor nesse livro para os nossos depoimentos rapsódicos.

\section{CADERNO DE RELATOS III}

(Relato de Janaína Silva, 28 de junho de 2013)

- estudo de 'O Ponto de Mutacấ' oferece um importante

embaramento teónico e

comprennāo histólica dos

paradignas de comportamento

social que $\widehat{\text { aOo }}$ urvelados atranés

do purcurro da física e vus derdobramentos

nas entras áreas do conhecimento.

1

Tos propomios a trazer sirpuimentacés prálicas dessas quistoes, através de figura do raprodo contemponâruo.
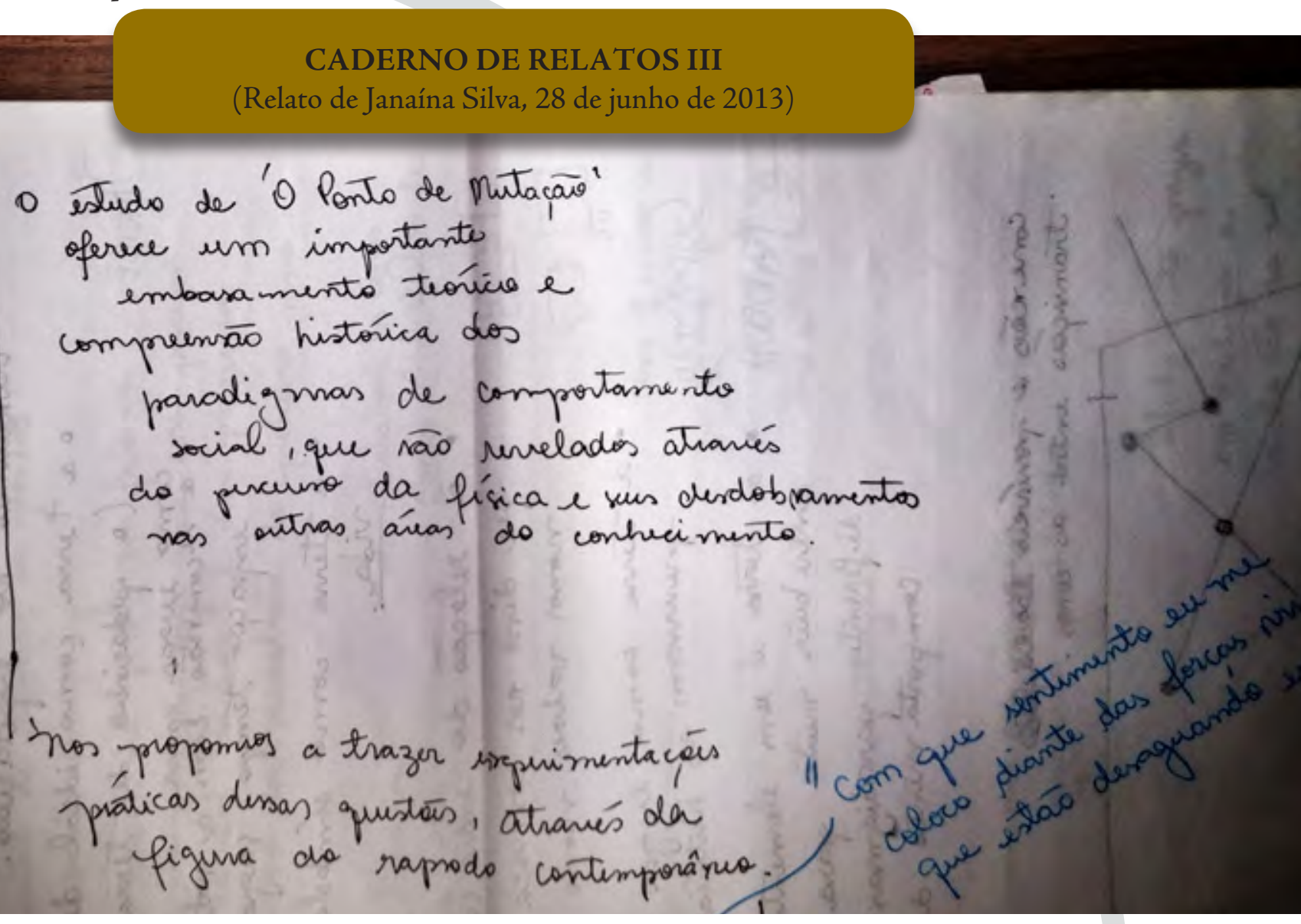

FOMOS SATURNDONOS dos assuntos trazidos no livro, que transita por diversas áreas do conhecimento: medicina, biologia, psicologia, economia, sociologia. Em diversos relatos dos cadernos, faço apontamentos de assuntos levantados nesse livro, estabelecendo relação com algum fato ou experiência vivida por mim ou compartilhada por outra pessoa.

\section{CADERNO DE RELATOS III}

(Relato de Renata Vendramin, 08 de julho de 2013)

Ressonâncias Leitura do Cap. III do Ponto de mutação, Capra

Ele fala sobre o modelo biomédico, solre a negaçäo da morte, robu a necessidade de uma profunda mudanga conceitual na visä́ médica de saúde el doenga.

Assuntos para as rapsodas:

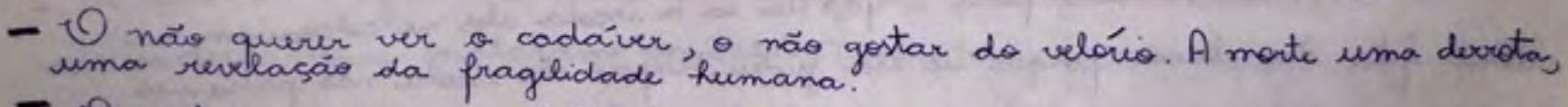

- Oprofessor escrevia a fórmula no quadro el eu perguntara de onde vinta...

Me mostra o rosto dessa persoa, pelo amor de Deus!!!!!!

- IT processo de cura da Acne, a accitaçäo do processo de cura. 
Para contribuir com a gestação dos depoimentos rapsódicos, decidimos escolher juntas, Janaína e eu, alguns trechos do livro de Capra que traziam ideiasreflexóessemsentidossentimentossentidos que nos interessavam deixar ressoar no espaçotempo de cocriação. Dessa maneira também começamos a limitar a infinita gama de possibilidades que a leitura nos trouxe. Uma escolha de direcionamento.

\section{CADERNO DE RELATOS III}

(julho de 2013)

\section{Trechos fundantes Falas Rapsodos}

19

universo é visto como uma tiia dinâmica de eventos interrelacionados. Nanhima das propriedades de qualquer parte dessa teia é funda mental; todas elas decovem das proprie dades das autras partes do todo, e a coerência total de suas interrulaçês determina a estrutura da tia.'

$\rightarrow$ transcender a metáfora do mundo como máquina, inteiramente contruída abandonas a idera de que a fúsica s'a base de toda a ciência. (1pla mão do criador.

I (..) as estruturas básicas da mundo material säo determinadas, em última instancia, pelor modo como observamas esse mundo; a que os modelos da (matéía säo reflexas de modelos da mente!

(nis existe pensodor, existe pensomento) Krishnamentti.

(1) Artista $x$ a sua arte.

INa física atômica, nöo pode mais ser mantida a nítida divisä̃ cartesiana intre materia es mente, entre o observado es observador. Nunca podermos falar da natureza sem, as mesmo tempo, falarmos solre nós mesmos!

1 Fa o mítodo de Descartes que tornou possivel ia NASA levar o homem a Lia. Por outro lade, a excessiva infase dada ao mitodo carteriano levou à fragmentagäo caracteústica do nosso pensamento em geral e das nossas dixciplinas acadêmicas, e levou à atitude generalizada de reducionis mo na ciencia - a cunça em que todos os aspectos dos fenômenos complexcos podem ser compreendides se reduzidos as suas partes constituintes!'

Descartes, ass 23 anes, depais de horas de meditaçäs, teve una visäe iluminadora, un chamado divine, intuine os alicuras de una nera ciência. 
Assim como nos outros textos de células cocriadas, criávamos uma primeira escrita, trazíamos para a relação, para experimentarmos juntas na cena, e assim íamos lapidando cada um dos textos que reconhecíamos coerente de ser entrelaçado à teia dramatúrgica.

No relato acima, de 08 de julho, escrevi uma ideiasemente para o texto que se tornaria depois a célula Soluções Inúteis. No dia 23 de agosto, pouco mais de um mês depois deste relato, cocriando simultaneamente várias células da peça, durante uma manhã em que lia o livro de Capra, parei a leitura e pari a primeira escrita da rapsódia Soluções Inúteis.

PAREI E PARI:

\title{
partodeescritafluxoinspirada
}

\author{
CADERNO DE RELATOS III
}

(Relato de Renata Vendramin, 23 de agosto de 2013)

\section{DEPOIMENTO RAPSÓDICO}

Qdo en tinha 4 anos en pedi pra minha pra ir pra Escola.

Exda era lugar onde se aprendia...

Adorava es conteridos, tinha preferências mas näo rejeitava essa on aquela matería, a dificuldade era um desatio que en

\section{Horosogy}

Me interessavar confecer mundos atra vés dos conteńdos a me interussava fazer parte dessa de aprendizado... admitava bodos os mens profensous.

Wde comecii a aprender Física no Colégio,

lembre que o professor colocou uma fórmula no quadro,

simples, ainda muito básices que explicava a Constituiçäe e a existencia de muitas corsas do que eu via da panela da Escola. Pra mim era difícil reduzir a salguiro da caffada iquela forma, enquadrar men cachovro aquelas letras, a ractaina de stio, a montansa, o meu anige, o meu conpo iaquela fómula. Priguntei: $i$ mas de onde vem isso?

$\checkmark$ professor se assustou. Acho que ninguém tima perguntado isso pra ile até entä...

E prontamente comescen a excuver uma fórmula matomáticá, mais inctensa, mair complexa, em várias linhas do quadro 
qdo ter minou, repousou o giz na lousa e disse

- Vem daqui!

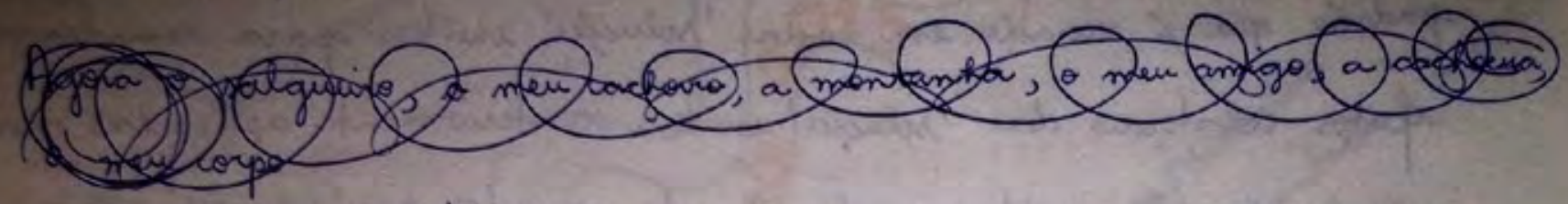

Ell olher aquela Pórmula-origem da Fórmula, e ainda näo fiqui satesfeita. 1) salguino, o meu cachouro, a montanho, o neu amigo, a cactoina, o meu corpo ainda pareciam incompativeis com áquelas 7 linhas.

Naquele momento eu näo consegui formular a pergunta que me faria chegar mais perto da minha buxa...
(Silencio)

- Professar en quero saber qual é o rosto humano dessa Fórmula?

- Eu quere confreer o coraçäo dessa mente brilhante!

- Eu quero saber o sentido da vida que essa pessoa en xergara oú?

- Me mostra uma foto dessa pessoa! Me diz onde le nascur, era frwo, calor? Ele tinha avé? 10 que ele gostara de comer? Ele ouvia música, cantava, rezara? Coma é que ele chegou nessa inspiraças?

- Ce criatividade desse humano estava a servico do que? Eu nä vim ao mundo pára ap̈render e reproduzir fórmulas ayja único objetivo í chegar à resultados que náo tum sentido nenhum pra mim!

Te intrevsa aprender os caminhos da inpiragão...

que me permitam aplicar, criar, reinventar foimulas/padrös/ manenas de cocriar vida es experiêncial. 
Eu näo estou aqui para vraar 'soluggeses' inúteis para problemas criador por 'soluçés' iníteis ja' aplicadas que vem de um pensamentol padras que é viciado em criar 'solucjes' iníteis para remediar os efeitor colaterais das 'solugses' iníteis anteviormente aplicadas nas resoluzaeis de probtemas do planeta, vriados por 'solugoes' iníteis. É mais fócil acabar com as 'soluçós' inuiteis, com Qs 'resultados' inúteis, con os 'padrous' inúteis.. É mais fácil raceitar olhar para o problema! E pode ser que ele nem exista!!!! Porque a gente purde tanto tempo criando 'solucoses' inúteis para os efeitos colaterais das 'solucois' inifieis que criamos anteriorrente. ¿E se a gente parar e Escutar???

\section{BLACK OUT}

Por esta época havíamos feito uma escolha de encarnar o depoimento rapsódico, textofaladocantadodançado, em um microfone que ficava na borda do círculo. A ideia era que a maioria das falas da peça em primeira pessoa acontecesse neste microfone. Ao poucos, com os diversos compartilhares com cocriadores, consideramos desnecessário o uso do microfone durante os depoimentos e passamos a utilizá-lo para criar qualidades, texturas de sons e sonoridades diferentes, como, por exemplo, nos sons que fazíamos quando a Figura Mítica (A Mais Velha que o Tempo) surgia no espaçotempo de cocriação.

O texto Soluções Inúteis foi experimentado sozinho, por mim, e entrelaçado a outro depoimento rapsódico escrito por Janaína, Doutor, tem gente aí?. Os depoimentos entrelaçados foram integrados à teia dramatúrgica, mudaram de lugar várias vezes, até que decidimos tirá-los da dramaturgia cênica para a abertura de processo em dezembro de 2013. A última versão que trabalhamos foi o texto entrelaçado das duas rapsódias:

\section{TRÂNSITO ENTRE OS DEPOIMENTOS SOLUÇÕES INÚTEISE DOUTOR, TEM GENTE AÍ?}

Uma atriz está sentada, a outra está de pé, ao microfone. Aos poucos os depoimentos vão se cruzando, tornam-se uma única vozz.

$R$ (no microfone): Quando eu comecei a aprender fisica no colégio, lembro que o professor colocou uma fórmula no quadro. Simples, ainda muito básica, que explicava a constituição e a existência de muitas coisas que eu via através da janela da sala de aula. Para mim foi difícil reduzir o árvore que eu via na calçada àquela forma, enquadrar o meu cachorro peludo àquelas letras, o meu amigo sentado na carteira do lado, a cachoeira do sítio, o meu corpo, àquela fórmula. Parei. Respirei. Perguntei:

- Ô professor, mas de onde vem isso? 
0 professor se assustou. Parou. Respirou. Acho que ninguém tinha perguntado isso pra ele até então... Ele prontamente começou a escrever uma fórmula matemática mais extensa, mais complexa, em várias linhas do quadro, quando terminou, repousou o giz na lousa e disse, orgulhoso:

\section{- Vem daquil}

Eu othei aquela pseudo fórmula-origem da Fórmula, $e$ ainda não fiquei satisfeita. A árvore, o meu cachorro, 0 meu amigo, a cachoeira, o meu corpo ainda pareciam incompatíveis com àquelas 7 linhas. Naquele momento, eu não consegui formular a pergunta que me faria chegar mais perto da minha busca...

J (sentada): Hoje eu fui fazer um exame de ultrassonografia num hospital do sistema único de saúde. $O$ médico não me othou nos othos. Não falou boa tarde. Foi logo pegando a bisnaga daquele gel de fazer o exame e tacando na minha barriga assim. No que eu falei boa tarde, ele olhou, de canto de otho. Só. Passava o aparelinho na minha barriga e começou a ditar, bem depressa os nomes e as medidas: diâmetro biparietal, circunferência cefálica, circunferência abdominal, cumprimento umeral, cumprimento femural, tibia, fibula, pé... etc, etc, etc... Doutor, eu não vou poder ver nada? Essa tela não vira, minha querida! Mas virou da outra vez que eu vim aqui, doutor. Eu pude ver, acompanhar os nomes e as medidas, ouvir o coraçãozinho... Otha, querida! Se eu deixo você ver eu não vejo, não passo direito as medidas! Aí tudo começou a ficar confuso. Já não sabia mais se eu tava mesmo diante de um médico, verificando as condições de vida de um bebê ou se era a fala de uma costureira apressada diante de um vestido atrasado pra entregar ou o quê. Se ao invés de ditar as partes do corpo da criança ele dissesse: 15 parafusos, 70 pregos, 18 porcas, daria na mesma também, não daria? Eu tava parada ali, com a barriga cheia de gel, com a cabeça girando. Eu tava ali esperando desde as sete da manhã, como outras. E como outras, estou esperando um bebê e seria muito importante poder ver o meu filho que eu sinto e ainda não vejo. Ai eu othei no otho do médico $e$ fui olhando fundo, fundo, fundo. E fui tentando buscar a humanidade que tinha ali. Tentando tirar tudo 0 que tinha ali - o jaleco, o relógio, os papeis, aquela sala improvisada, o cansaço dele em atender a número cem do dia, ou mais... quem sabe por ali escapasse o homem que tem ali. Tinha gente ali. Eu sei que tinha. Debaixo de todo aquele sistema tinha gente ali. R: - Ô Professor! J: Doutor! Tem gente ai? R: Eu quero saber 0 rosto humano dessa Fórmula! J: Tem gente aqui! Tem gente aquil!!! R: Eu quero conhecer o coração dessa mente brilhante! Eu quero vislumbrar o sentido da vida que essa pessoa enxergava aí! Me mostra uma foto dessa pessoa! J: Tem gente ai, não tem? R: Me diz onde ela nasceu? Era frio, calor? Essa pessoa tinha bisavó? O que gostava de comer? Ouvia música, cantava, rezava? Como é que chegou nessa inspiração? A criatividade desse humano estava a serviço de quê? J: Mas eu não abri a boca pro doutor. Eu limpei a barriga, subi a calça, eu engoli o choro e passei pelo doutor e pelo corredor cheio de outras vidas com outras vidas dentro com a cara estatelada me sentindo pequena, minúscula, invisivel, insuficiente, um pedaço de qualquer coisa mal feita. Uma pequeneza vulnerável diante dessa força invisivel que deve receber muitos nomes e que muitos chamam de o sistema! Não. Eu nessałhora não tô mais falando só do sucateamento do SUS nem só do setor público e do setor privado nem de mim nem de você, só, doutor. Eu tou falando desse sistema nós. Desse nosso sis te ma mentalidade e comportamento de alimentar relações de poder e dominação, esse nosso sistema de reagir às coisas assim estatelado e calado. Do sistema nós de reproduzir os mesmos comportamentos e repetir as mesmas histórias e mal reproduzir as mesmas palauras. O mundo caindo e a gente imerso nele agindo como se visse tudo do lado de for a como se visse tudo na televisão e fosse só trocar o canal ou pagar mais caro ou não se relacionar com esse tipo de gente ou coisa que pluft! sumiu a coisa o bichão o monstro e pronto, resolvido! R: Eu não vim ao mundo para aprender e reproduzir fórmulas cujo único objetivo é chegar a resultados que não têm sentido nenhum pra mim. Me interessa conhecer os caminhos da inspiração... Eu estou disponivel para conhecer os caminhos da inspiração. Que me permitam aplicar, criar, me libertar, reinventar fórmulas, padrões, maneiras de cocriar vida e experiência! J: Doutor, o senhor me desculpa... é que esse encontro me fez pensar em nós. E no fato de que somos indissociáveis. Somos parte de organismos de uma mesma rede. Ainda que você agora represente o médico e eu a paciente. Que aqui eu seja a atriz e você o espectador. Que uma hora você seja o que fala e eu o que escuta. Que depois ele seja o que ensina e eu o que aprende. Ela a que vende e você a que compra. Ele o que nasce e ele o que morre. Você o que sonha e você o que desacredita. Você a que cria e ele o que reproduz. Ainda que uma classe inteira nos separe. Que eu nem saiba da sua existência e que você esteja pouco se fodendo pra mim. Ainda que você leia a bíblia e ela o i ching, que você vá na igreja evangélica e ele na yoga, que você leia Marx e você passe ofim 
de semana no shopping! A planta, o cachorro que late, a vizinha que fala, o coração do meu filho que bate ainda dentro de mim, a chuva que chove do outro lado do mundo, você na sua casa de campoe eu na minha kitnet. $O$ grandão, o poderoso, o rico, o quase rico, o emergente, o pobre, o miserável, 0 branco, o preto, o índio, o misturado, o estrangeiro. Nós estamos todos aqui. Organismos de uma mesma rede de inter-relações. Mesmo que a gente discorde e que a gente queira de modos diferentes a paz que de um mesmo modo a gente ainda não sabe vivenciar... Não tem jeito! $O$ que eu faço aqui $e$ que você faz aí... Reverbera, ecoa, ressoa, gera eonsequência! R: Eu não estou aqui para criar 'soluções inúteis' para problemas criados por 'soluções inúteis' anteriormente aplicadas, que vêm de um pensamento/ padrão que é viciado em criar 'soluções inúteis' para remediar os efeitos colaterais das 'soluções inúteis anteriormente aplicadas nas resoluções de problemas do planeta. Problemas estes, em sua grande maioria, criados por 'soluções inúteis'. É mais fácil acabar com as 'soluções inúteis', com os 'resultados inúteis', com os 'padrões inúteis'... J: Reverbera, ecoa, ressoa, gera consequência! Sobre consequências... eu só queria dizer, doutor... aqui nesse mundo que tá grávido de ou- tro, numa realidade que é, diante de uma realidade que pode ser... te peço... e é pedido de uma nova mãe, de um novo ser que vai chegar no mundo: por favor! Cuidado com o que diz e pensa e imagina e planta aqui nesse nosso mundo quintal. Cuidado sair por aí assim, pensando, falando, desejando... R: É mais fácil aceitar olhar para o problema! E pode ser... pode ser? Pode ser! Pode ser que ele nem exista! Porque a gente perde tanto tempo criando 'soluções inúteis' para os efeitos colaterais das 'soluções inúteis' que criamos anteriormente. J: Eu assumo a minha responsabilidade de mãe... e o senhor, doutor? Assume a sua responsabilidade de ser humano diante de um novo ser vivo que vai conviver com você, nesse mesmo quintal? R: Ese a gente parar e escutar? E se a gente entender que há uma responsabilidade coletiva sobre tudo 0 que acontece aqui... uma responsabilidade coletiva sobre cada um que nasce, vive e morre aqui... que você é responsável pelo que pensa, pelo que cria, pelo que faz e pelo que não faz no mundo... e é responsável por mim e eu por você e nós dois e ele, e ela e ela...por esse ser que vem chegando no mundo... será que assim a gente consegue imaginar a próxima história?

Os trechos que estão em negrito, mais para o final do texto, Janaína e eu dizíamos juntas, numa falamúsicaritmada, sobrepondo vozes, tons... Eu particularmente gostava muito do texto e do caminho rapsódico de formalização da célula que estávamos cocriando. No entanto, algumas falas de cocriadores depois de alguns compartilhamentos que fizemos, diziam que o texto repetia assuntos trazidos em outras células da peça, às vezes era afirmativo demais, ou parecia uma síntese da peça, e a maneira como estava entrelaçado na dramaturgia cênica, quase no final da peça, tornava-o cansativo demais, pois era um texto longo e já havia acontecido muita coisa antes. Uma fala ou outra também dizia que o texto e a maneira que escolhemos encarnar esta célula eram pouco teatrais - do que discordo completamente.

Ressoando e assentando a experiência dos ensaios e dos compartilhamentos, decidimos tirar essas rapsódias da teia dramatúrgica para a abertura de processo em dezembro de 2013. Trabalhamos até aqui com elas no primeiro ciclo.

Quando começamos a R E S P I R A R o SeGUNDO CICLO, no primeiro movimento de retorno a tudo que havíamos cocriado até ali, além das células que sabia que estariam na dramaturgia cênica da peça, senti vontade de retornar a dois textos, com o desejo de investigar mais a fundo as suas musicalidades: Soluçôes Inúteis e $O$ Parto do Bebê-Mundo. ${ }^{52}$

Não por coincidência, ambos os textos foram escritos por mim. Eles têm um caráter de depoimento que, a meu ver, faz com que caibam somente em minha boca, em meu corpovoz. Não cogitei retomar nenhum depoimento escrito por Janaína ou dito por ela durante a peça. Os textos retomados foram os escritos a quatro mãos (e cocriado a várias mãos), ou, como no caso da fábula da célula Infância, um texto que nasceu de um depoimento pessoal e transformou-se em uma narrativa fabulada. 
Quando a nova organização da dramaturgia cênica encarnou (ao final de um ensaio em que trabalhava sozinha com a célula A Mais Velha que o Tempo), o texto Soluçóes Inúteis estava entrelaçado nesta nova proposição da teia dramatúrgica. Então o caminho foi partir para a relação, descobrir como relacionar-me com o texto neste novo momento e deixar ressoarem os sentidos e semsentidos, para descobrirmos se era de fato coerente que ele permanecesse.

No primeiro momento, parti para ensaios $\mathrm{S}^{\mathrm{Z}} \mathrm{ZINHA}$ EM COCRIAÇÃ O, no nosso espaçotempo saturado. Comecei a relacionar-me com o texto sentada no pequeno banco (o nosso iamá), que também foi trazido novamente para o círculo. Agora tínhamos um banco no centro (que logo mais se transformaria em um toco de árvore) e outro colocado na borda do círculo: o lugar do depoimento rapsódico.

Sozinha, só me restava experimentar, relacionar-me com os elementos que estavam ali até então. Como o desejo era trabalhar com a musicalidade do texto, deixá-lo desdobrar-se em música e dança, comecei a relacionar-me com as palavras do texto, com o fluxo da minha escrita, que já propunha algumas variaçóes de ritmos. Sentada no banquinho, com o texto perto, comecei a relação em escuta, com paciência...

\section{Faixa 24}

(O) DVD 02 / Faixa 24

Da relação com as palavras e as musicalidades do texto, aos poucos começaram a surgir os impulsos para os primeiros movimentos corporaisvocais, e, junto com eles, sentidos e semsentidos começaram a encarnar. Livre o máximo possível de julgamentos e expectativas, sem tentar espremer formas e sentidos, dei vazão aos movimentos que abriam espaços em meu corpovoz, que criavam e descobriam sentidos por meio dos movimentos livres do meu corpovoz em relação com as palavras e musicalidades do texto. O espaçotempo de cocriação e meu corpovoz foram sensibilizados e aquecidos nas práticas feitas antes deste movimento de lançar-me na cocriação livre.

Os movimentos foram nascendo dos impulsos do meu corpovoz, sendo repetidos, despertando sensações que me conduziam em fluxo a aprofundá-los, lapidá-los, redesenhá-los. Fui guiada pela intuiçãoinspiraçãoexperimentação, pelo fluxo e ritmo criativos.

\section{Faixa 25}

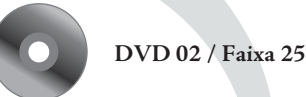

Os movimentos foram maturando sem que eu precisasse fazer alguma intervenção muito incisiva, as escolhas foram sendo feitas em escuta, o meu corpovoz fazia as escolhas, que não eram somente racionais. Os movimentos foram assentando-se no corpovoz, gerando sentidos e semsentidos, abrindo e ampliando-os. A respiração criava movimentos, os movimentos davam ritmos à respiração, fazendo surgir sons, musicalidades, variações de ritmos e tons diferentes de falas.

Tudo isso COcRIAVA-SE EM RGLAÇÃO: relação do corpovoz com o texto, do texto com o corpovoz, da respiração com o texto, do texto com a respiração, do corpovoz com o espaçotempo de cocriação, do espaçotempo de cocriação com o corpovoz, da respiração com o espaçotempo de cocriação, do espaçotempo de cocriação com a respiração... suportando permanecer NEsTE E S P A Ç O TEMPO $\mathrm{C}_{\mathrm{A}} \mathrm{o}^{\mathrm{T}} \mathrm{iCo}$, InFO ${ }^{\mathrm{R}} \mathrm{ME}$, onde tudo é possível, até que as formas começassem a encarnar... repetindo, fazendo, refazendo, abandonando, retomando, respirando, SUPORTANDO HABITAR este espaçotempo dos semsentidos, dos sentidos infinitos, fluídicos, desejantes de serem encarnados. 


\section{CADERNO DE RELATOS IV}

(Relato de Renata Vendramin, 02 de junho de 2014)

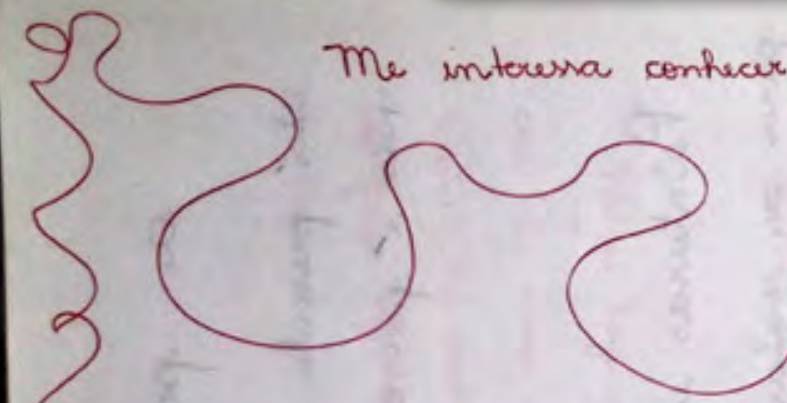

Relacäo com o texto 'Soluçä Pruítis'

Danga livere no aquecimente com

música de Lila Lourm (Yjuen Nimu)

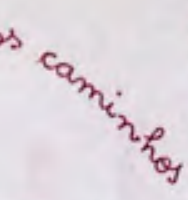

$02 / 06 / 14$ - Sala $22-$

para estar no espace, no meu corpo, de maneira live

Se apuesenta uma necessidade de FENDAS DE IMPROVISO no espetáculo. Assim como já acontece na

DO MOMENTO/MANIFESTAÇÃO
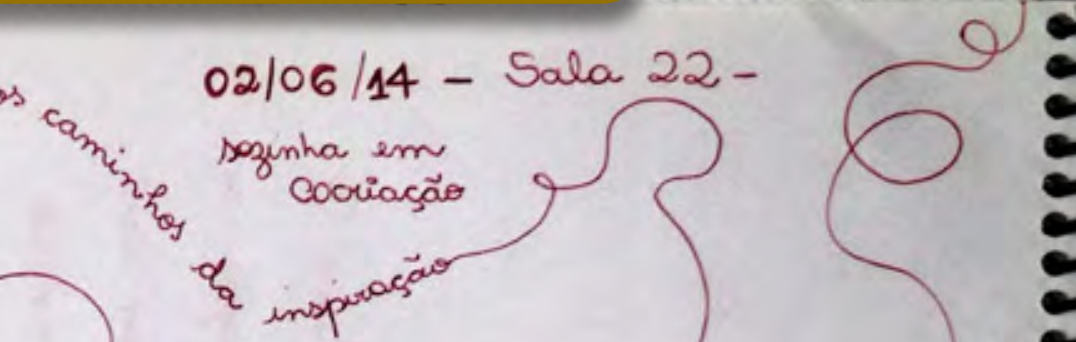

Cooriaça
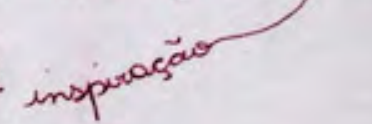

pergunta da infancia, nos 'Imaginamentos', ter, além

de presente.

desses umprovuses / cocriaçäo im xelaşäo com o públice na palavra,

outros momentos de dança, múrica i canto.

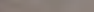

SINTO LIBERDADE. BROTA DA PRESENCSA

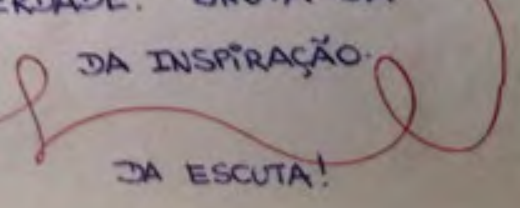

Eu usava também o recurso da câmera para ver o resultado plástico dos movimentos cocriados. Via depois do ensaio finalizado - da experiência do dia concluída - e ajustava detalhes, como, por exemplo, há um momento na célula em que levo as mãos aos olhos e estava cobrindo quase todo o meu rosto, achei que ficaria melhor cobrir menos a face e ajustei as minhas mãos para isso. No entanto, a maioria dos movimentos foi sendo maturado e lapidado no fluxo criativo, pelos sentidos e semsentidos que foram gerados durante a experimentação.

A dança apareceu nesta cena de maneira muito orgânica durante a minha experimentação - quero dizer, movimentos mais "puros" de dança em relação com a música e com a palavra. Durante o primeiro ciclo do processo, muitas vezes fiquei frustrada e intrigada por não conseguirmos deixar a dança se manifestar com mais liberdade e de maneira mais "pura", com sua lógica própria de cocriação de sentidos. Era muito penoso abrir mais espaço e tempo, mais espaçotempo, dar-nos mais tempo e espaço, para esta qualidade de cocriação no primeiro ciclo.

A impressão que tenho é que era muito difícil suportar permanecer neste espaçotempo de experimentação da dança (e seus caminhos nada racionais de cocriação de sentidos) juntos (as cocriadoras que integramos o sistemaprocesso), e quanto mais gente tinha, pior; se tivesse gente olhando de fora então, pior ainda. Faltaram receptividade, abertura, escuta, paciência; faltou suportar permanecer no espaçotempo dos semsentidos, dos SENTIDOS FLUÍDICOS, com o corpovozconectivoreceptivo, respirando, para aos poucos começar o movimento de encarnação, que também é uma dança. Creio que para isso precisávamos de mais prática, de exercitarmo-nos, fazer, refazer, expor-nos, assim podemos desenvolver a musculatura para suportar habitar este campo de forças que é o espaçotempo de cocriação, respirar este/neste sistema nervoso. 


\section{O MOVIMENTO DE ENCARNAÇÃO É UMA DASNCCÂA.}

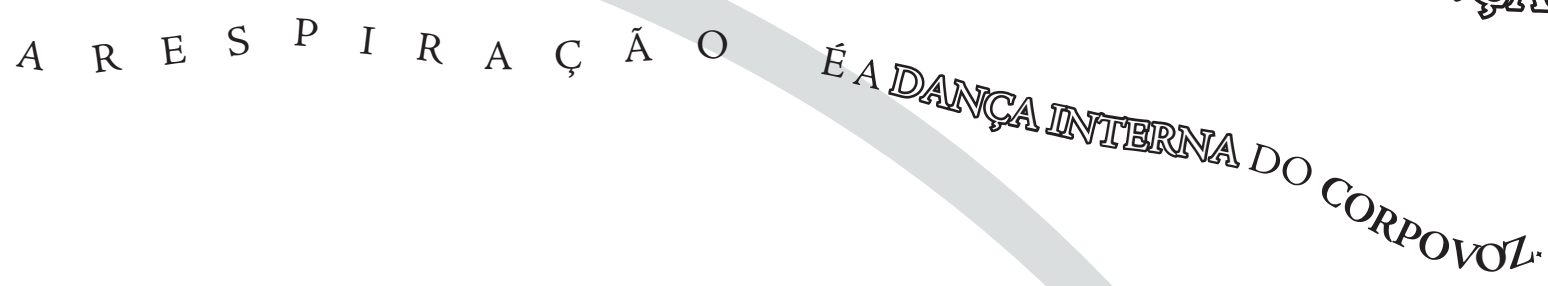

\section{Faixa 26}

e depois voltar para acharmos

crescendo junto à nossa porta a planta

que queríamos. Não é raro encontrar, muito depois de terminar a encenação de uma peça,

uma anotação ou um pequeno esboço que haviam sido descartados e completamente esquecidos, provando que em algum lugar do subconsciente estava a resposta que levamos meses de investigação para descobrir. [...] É sempre o mesmo processo de tentativa e erro, pesquisa, elaboração, rejeição e acaso que faz com que a interpretação do ator tome forma, que o trabalho dos músicos ou do iluminador se integrem num todo orgânico.

[...] É preciso haver muitos esforços, todos eles criando um campo de energia que em dado momento crítico atrai para si a solução. (BROOK, 2008,

\section{Faixa 27}

r E s $P$ i $R$ o $\quad$ L o $G$ o $\quad E \times$ I s $T$ o

r E s P i R o $\mathrm{L}_{\mathrm{o}} \mathrm{G}$ o $\mathrm{C}_{\mathrm{r}} \mathrm{I}$ o

r E s P i $\mathbf{R}$ o $\quad \mathbf{L}$ o $\mathbf{G}$ o $\mathbf{V}$ i $\mathbf{V}$ o

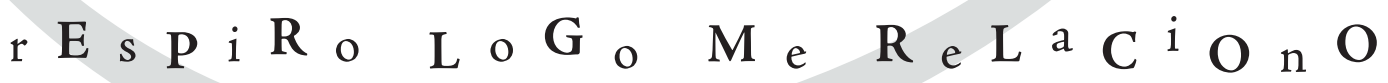

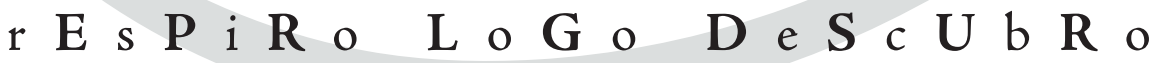

r E s P i R o L o $\mathbf{G}_{\text {o }} \mathbf{C}_{\text {o }} \mathrm{N}_{h} \mathrm{E}_{\text {c }} \mathrm{O}$ 
Depois desses ensaios sozinha em cocriação, já com algumas escolhas de movimentos corporaisvocais feitas, fui para a relação com o Alencar. A princípio, eu acreditava que o Alencar entraria com algum instrumento musical para compor junto com as palavras, o movimento corporal e a melodia que eu havia cocriado para o trecho da célula em que falocanto a palavra inspiração. Alencar, assim que conheceu a minha proposição, disse que não ouvia instrumentos ali, que a música da cena já acontecia na relação com a palavra, com os movimentos corporaisvocais. Achei coerente a observação e reconhecemos juntos que inserir algum instrumento musical nesta célula seria desnecessário, excessivo, um gosto pessoal, virtuosismo, não um desejo genuíno da célula, para expandir as ressonâncias, os sentidos e semsentidos, e encorpar a teia dramatúrgica.

A partir daí, fizemos, refizemos, compartilhamos com cocriadores. Aos poucos foram chegando ao espaçotempo de cocriação os figurinos, a iluminação, e a cada novo elemento que se integrava havia um período de experimentação necessário para deixar a nossa relação orgânica.

\section{Faixa 28}

DVD 02 / Faixa 28

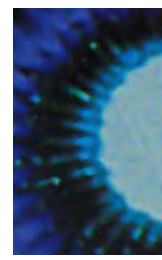

\section{CÉLULA S: INFÂNCIA}

Com as nossas narrativas de infância e os objetos pessoais trazidos para o espaçotempo de cocriação, esta célula começou a ganhar contornos.

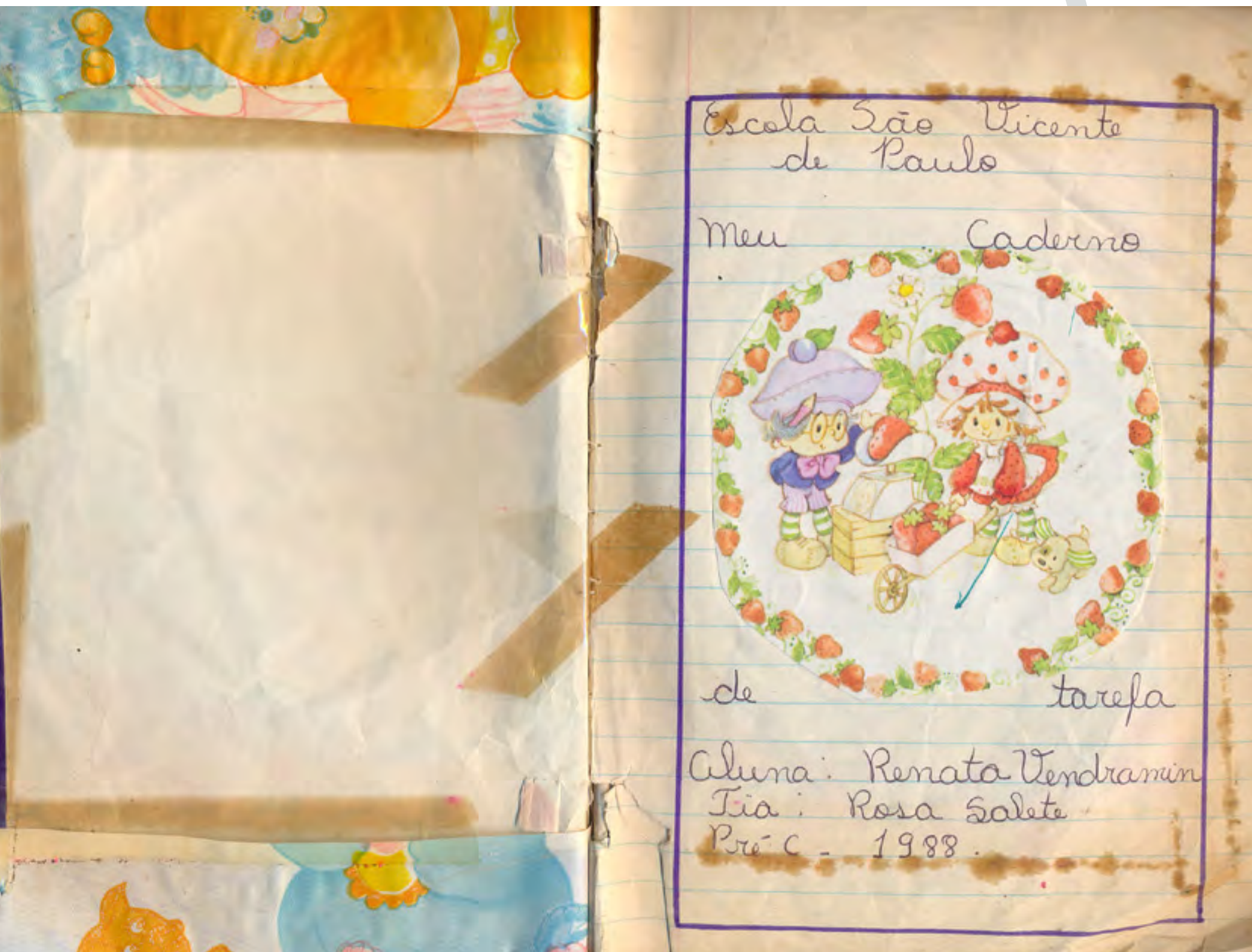


As narrativas de infância estiveram conosco desde o princípio do sistemaprocesso, quando começamos a $\mathrm{E}_{\mathrm{X}}$. PERIMENTA ${ }^{\mathrm{R}} \mathrm{O}$ IAMÁ: sentando no pequeno banco de madeira e contando histórias livremente, seguindo o fluxo do momento presente, da maneira mais natural e ingênua possível, deixando-nos atravessar pelas emoções, sensações, sentidos e semsentidos, reflexões que a ação de contar aquelas histórias nos proporcionava. $\mathrm{O}$ "contar livremente", sem nada além de nós e do banco, aos poucos foi modificando-se, numa evolução natural; começamos a trazer objetos, uma peça ou outra de figurino, conforme sentíamos vontade, e seguimos experimentando com muita liberdade, sem nos preocupar ainda em formalizar células.

\section{Faixa 29}

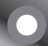

DVD 02 / Faixa 29

Dentre tantas narrativas que se revelaram, que descobrimos, buscando por diferentes e novas histórias na nossa família, duas delas, a do Pé de Chupetas e a da Lua, sempre retornavam: na palavra narrada, no movimento corpovoz, nos sons durante as práticas e improvisações experimentados. Como se através delas conseguíssemos nos aproximar de um...
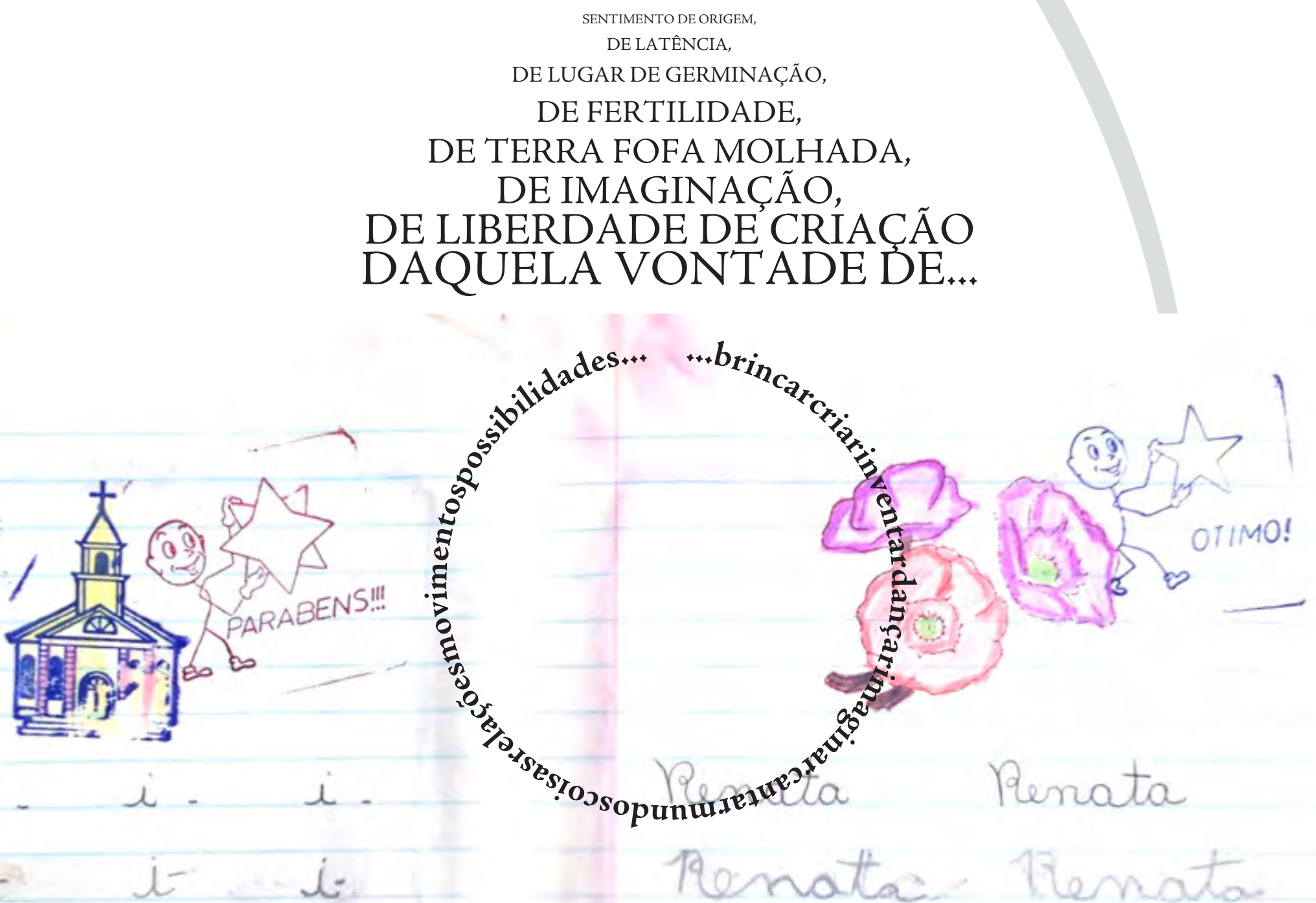

... que nos interessava vibrar na peça: a atmosfera, o estado, a instância da infância. A infância é um período da vida, um estado em que, como diria Eduardo Galeano, "somos todos pagãos e poetas, depois o mundo se ocupa de apequenar nossa alma".,53

Surgiam então perguntas: como trazer essas narrativas para a cena? Como trazer as narrativas pessoais e ampliá-las a ponto de encarnar problematizações que digam respeito a todos que compomos a experiência teatral?

${ }^{3}$ Depoimento de Eduardo Galeano em vídeo, disponível em: https://www.youtube.com/watch?v=gujK5WEVG8g 
Sempre que compartilhávamos essas narrativas com o público, desde os primeiros experimentos mais ingênuos, despertava-se um sentimento de pureza, de frescor, um respiro de confiança, de fé, de esperança, qualidades todas características do ESTADO infância, como se, ao ouvir as nossas histórias, as pessoas relembrassem as suas histórias e se conectassem à própria infância. Não somente à infância histórica, datada, vivida, passada, mas a um sentimento de infância que nos acompanha durante toda a nossa existência e que nos é tão precioso para que a vida seja um MOVIMENTO CЯIATIVO. Como se a gente recordasse da nossa capacidade, da nossa habilidade, do nosso dom de cocriarmundos.

Esse sentimento de infância, sabíamos que queríamos na peça, pois o despertar desse estado infância era uma condição necessária para conseguirmos desenhar novas geografias para as próximas histórias.

E como seria a célula? Qual seria o textovozcorposompalavramovimentomúsicasonoridade que nos conduziria a essa instância? Nos improvisos, experimentos, no contar livre das histórias, conseguíamos despertar esse sentimento que tateávamos; na formalização de uma célula será que conseguiríamos manter esse frescor?

As perguntas estavam no espaçotempo de cocriação, sendo respiradas, e começaram a surgir, junto com os experimentos corporaisvocais dessa atmosfera da infância, as primeiras propostas de textopalavras. Desde a pRIMEIRA escrita (um textoembrião) lançada no espaçotempo de cocriação, o Jogo do Trânsito ${ }^{54}$ estava presente. Esse jogo norteava a cocriação de todas as células e da dramaturgia cênica como um todo. Nessa primeira escrita, o trânsito acontecia num jogo entre a primeira e a terceira pessoa. Estávamos sempre contando a nossa história em primeira pessoa e narrando a narrativa da outra em terceira pessoa.

\section{PRIMEIRAESCRITA: O ELEFANTEE A LUA 55 (escrita por Renata Vendramin)}

Alguém escolhe o caderno de tarefas ou o elemento que leve pra história da lua. (Qual é?)

Dança que instaure a atmosfera da infância, da confiança, do olhar fresco e crente na vida. Investigar o movimento e a composição musical juntos, cada uma descobrir quais os movimentos individuais e em relação que presentificam essa sensação, intenção).

No microfone: Que chaves abriram a casa da sua memória?

\section{O ELEFANTE}

\section{R: Eu tinha 4 anos.}

\section{J: Ela tinha 4 anos.}

R: Eu sou a filha caçula de três irmãos, e nessa época meus irmãos mais velhos já iam pra escola, e eu ficava em casa sozinha à tarde, sem ninguém pra brincar. Eu pedi pra minha mãe pra ir pra escola.
J: Ela pediu pra mãe dela pra ir pra escola.

R: Entrei no Jardim da Tia Rosa Salete. A Tia Rosa Salete tinha um cabelo com permanente, tipo poodle. Todos os dias ela passava uma tarefa pra eu fazer. Eram pontos pra ligar, maçãs para contar, jogo dos 7 erros, letras pra desenhar, desenhos para pintar. Um dia, eu abri meu caderno de tarefas e encontrei com um elefante pra pintar.

${ }^{54}$ Entrelaçamento com o texto da página 37.

55 Antes deste texto, já havíamos escrito outros textos, fazendo o trânsito entre nossas narrativas pessoais. Com um deles, chamado Pé de Memória, participamos de uma roda de histórias no evento Boca do Céu (Encontro Internacional de Contadores de Histórias), em São Paulo, em 10 de setembro de 2012. 
J: Ela abriu o caderno de tarefas e encontrou com um elefante pra pintar. Já ia abrindo um sorriso nos lábios quando se deu conta de uma coisa importante. R: Eu me dei conta de uma coisa muito importante. Os elefantes são cinzas!

J:Os elefantes são cinzas!

R: E eu tenho uma caixa de lápis de cor com apenas 12 cores! Eu não tenho cinza! Como é que eu vou pintar o meu elefante???

\section{J: Ah, pinta de azul!}

R: Não!!!! Não era possível, eu gostava de pintar as coisas com as cores que elas são!

Naquela época, eu tinha um sonho.

J: Ela tinha um sonho de ter uma caixa de lápis de cor com 36 cores, com cinza, lilás, verde água, azul piscina...

$R$ :...com todos eles apontados, com a ponta grande! Naquele dia, eu tinha um problema muito grande para resolver. Provavelmente o maior problema da minha vida até então.

J: Ela pegou o caderno, a caixa de lápis de cor de 12 cores e correu pro quarto do pai. Com o coração na mão, explicou a sua situação de vida ou morte.

R: Meu pai me olhou e disse tranquilamente: "Calma filha, pra tudo tem um jeito, é muito simples..." Ele pegou o lápis branco e pintou todo o elefante. (Faço o movimento de pintar o caderno.)

J: Depois ele pegou o lápis preto e foi passando bem de leve por cima do branco...

$R:$ :.. e o elefante...

J.... como num passe de mágica, foi ficando...

R: ... cinza!!! O cinza mais bonito que eu já tinha visto!

J: O cinza mais cinza de todos os cinzas!

R: O cinza mais... Era o elefante mais lindo do mundo!

Microfone: Que primeiras vozes tocaram a pele da sua alma?
R: Ela, chorava, chorava... Chorava sem motivo. Chorava tanto, e ninguém sabia o porquê.

J: Não tinha o que me fizesse parar de chorar. Meu pai contava histórias pra ver se eu parava de chorar, e nada.

R: Ela esgoelava mais ainda. É fome?

J: Não!

R:É sono?

J: Não!

R: Alguém fez alguma coisa pra ela?-

J: Não! E eu chorava! A minha avó vendo o desespero do meu pai, trazia doces, pra ver se eu parava de chorar, e... nada!

R: Daí que, em frente da casa da vó dela, tinha um toco de árvore que servia de banco. Numa dessas noites em que ela chorava...

J.... chorava, chorava...

R:É fome?

J: Não!

R:É sono?

J: Não!

R: Alguém fez alguma coisa pra ela?

J: Não! Meu pai teve a ideia de me levar pra sentar no toco pra ver a lua...

R: O pai dela teve a ideia de levá-la pra sentar no toco pra ver a lua...

Je R: A uuuuuua, Jana! (Sobreposição.)

$J$ e R: Era o elefante mais lindo do mundo! Era o cinza mais cinza que já existiu! (Sobreposição.)

Je R: Quais as primeiras chaves? 
A célula se iniciava com uma proposição de movimento corporalvocal, seguida de uma pergunta direcionada ao público, mas que, neste momento, não era pra ser respondida verbalmente. Um dos nossos desejos nesta célula era trabalhar mais a fundo com o movimentodança para a cocriação de sentidos e semsentidos em relação com os demais elementos. Com a proposta de textopalavras, voltamos para a prática, para botar corpovoz e, a partir das palavras concatenadas, deixar que as perguntas, sentidos, reflexões, semsentidos, sensações se maturassem e encarnassem no espaçotempo de cocriação.

Em setembro de 2013, no primeiro ensaio, com o músico Alencar, propusemos uma experiência com a instância da infância e o movimentodança.

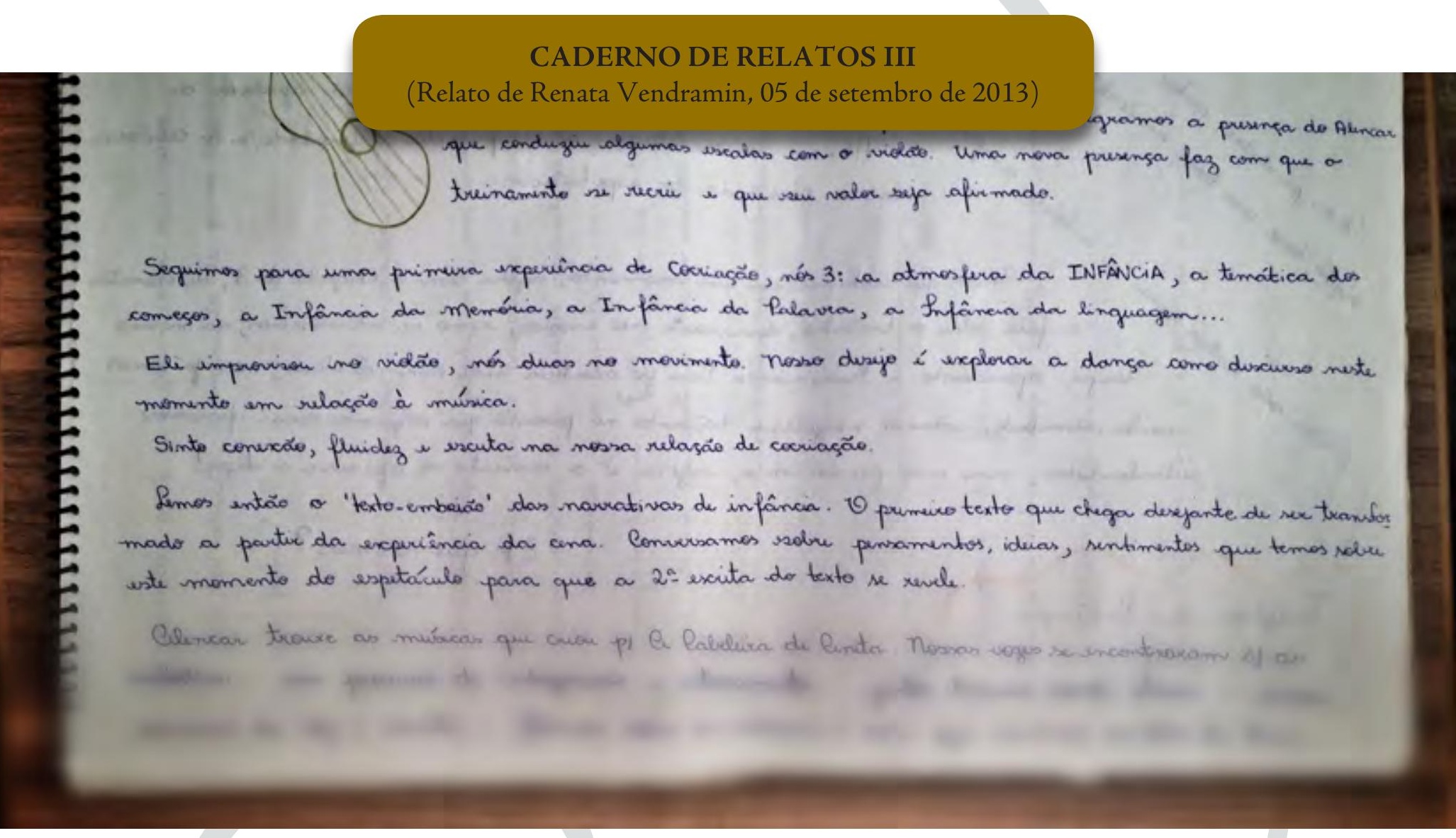

A partir da primeira escrita (junto com os experimentos corporaisvocais e reflexóes coletivas), Janaína propôs uma SeGUNDA escrita para o texto, misturando outros trechos de narrativas de infâncias que havíamos contado. As narrativas foram entrelaçadas entre si e com propostas de movimento corpovoz. Essa segunda escrita também trouxe perguntas reflexivas ao início do texto que ainda não pensávamos em fazer ao público. Mais uma vez fomos transpirar a proposta, e um pensamento recorrente era que precisávamos mudar um pouco o texto, as palavras e as falas coloquiais. Queríamos manter o contar ingênuo, informal, que gerava uma certa cumplicidade e afetividade com o público; mas queríamos também expandir os sentidos das narrativas cotidianas. Além disso, acreditávamos que, da maneira como estava (o entrelaçamento das duas narrativas contadas de maneira coloquial), não era o bastante para criarmos uma dinâmica expressiva para a célula. O Jogo do Trânsito parecia ainda não ter sido explorado em sua potência máxima.

Janaína propôs que criássemos fábulas a partir de nossas narrativas de infância, a ideia era escolher uma delas e fabular. Assim, retornaríamos à baliza do Jogo do Trânsito como fazíamos no começo do sistemaprocesso: com o entrelaçamento de uma narrativa fabulada (que surgiria a partir da nossa proposição) e alguma narrativa pessoal, contada de maneira coloquial e mais improvisada. Acredito que, com essa proposta, começamos a perscrutar sutilezas e detalhes dessa dinâmica do trânsito ainda desconhecidas. 
Foi, então, que, na TErCEIRA escrita do textopalavras, floresceu a narrativa da Lua fabulada por Janaína:

\section{TERCEIRAESCRITA: A INFÂNCIA DA HISTÓRIA}

(escrita por Janaína Silva)

(Uma das atrizes pergunta pra algumas pessoas do público.)

Onde é que estão guardadas as histórias da sua infância? Onde você acha que elas foram parar?

(Outra atriz pergunta pra alquém do público.)

Você lembra alguma história desses tempos? Uma história que se possa contar?

Diziam que aquela menina era entristonhada de outras vidas, já! É! A menina era tinhosa demais pra dormir... tinha olheiras enormes, não durmia nem com reza. Tinha espanto do silêncio da noite! E isso dava motivo pra todo tipo de explicação médica: "Isso daí é mau olhado, vizinha! Bom cuidar com chá de carqueja!", "Ah! Obra do ruim, viu? Coisa boa na outra vida a sujeitinha não deve ter feito...", "A pessoa quando não consegue dormir, é que não tá em paz com a consciência!" - Mas a menina só tem quatro anos!?! - "Ué?! E desgraça tem idade? Já acompanha de outras vidas..." Inda se fosse só a insônia! Mas bastava dar seis da tarde, o sol saía, e a tristeza da menina chegava! As galinhas iam se empoleirando pra dormir, e já batia o desespero na coitada! Era a natureza trocar de dono, que a menina garrava num choro descontrolado que espantava todo mundo! $E$ nada dava jeito! A vó uma vez ficou sabendo de um velhinho benzedor que curava de um tudo e levou a menina: 0 velhinho olhou, pôs othos de bom senso... e antes de receitar qualquer mandinga... agachou até a medida miúda da menina, olhou de igual pra igual, encontro de alma antiga... alma com alma, no profundo do othar... e lá no meio da bola preta do olho, foi dar de cara com o espanto, aquele monstro que não deixava ninguém dormir! "Onde dói?" A menininha tinha o coração disparado; mas, sem que ela mesma tivesse tempo de enfiar a cara no suvaco da vó, a boca abriu primeiro! Falou, apertando o peito: "é por aqui, assim..." Ecomo é que é a dor? "Dói uma dor de antes! De quando eu morava lá, com ela..." E apontou, na janela, a Lua, que tava cheia, gorda, pesada, fazendo um clarão na consciência... A vó se arrepiou feito gato e soltou uma palaura mal emendada na outra, tentando virar frase: "... a primeira palaura que ela aprendeu a falar foi Lua!" Equem é que ia duvidar que a menina tinha mesmo vindo de lá? $O$ benzedor deu a receita: É dor de saudade! Toda vez que ela chorar, bota pra vê a Lua! A menininha, como se tivesse tomado xarope colorido de pronto efeito, esmiuçou um sorriso miú- do no canto da boca. A receita da alma antiga era... doce! A vó pegou firme no pulso da menina, fez que sim com a cabeça e desse mesmo jeito tomaram 0 rumo da rua... $O$ pescoço dançava um sim, mas na cabeça, envolta numa esquisitice de pensamentos, dançava uma desconfiança: "Saudade... Saudade de quê?? E criança lá tem saudade?" Nas obviedades daquela cabeça adulta, criança erá criatura que só colecionava instantes, só tinha compromisso com o agora... memória de criança vive de minutos! Mas a da menina, não. Deu pra guardar saudades sem idade e ainda por cima de uma esquisitice de ter morado na brancura da Lua. Mas se pra curar aquele berreiro era só botar a menina pra ver a Lua boiando no breu da noite... que mal tinha lambuzar o dedo naquele devaneio? Pra que contrariar? Quando as duas apareceram na ponta da rua, o Sol já tava baixo, enrolando pra ir embora, só pra dar tempo das duas chegarem em casa. "E lá vem a noite..." A menina já começou a ficar encruada, formando cara de choro, quando a vó parou no portão da casa e sugeriu sentarem no toco. "Borá ver a Lua?" A menina se alegrou. "Eu conheço lá, vó! Já fui sozinha até o pé da Lua e voltei!" Aquela conversação soava tão fresquinha e inocente nos ouvidos, que a vó esqueceu da hora da janta e se alimentou de vez naqueles devaneios... parece até que tinha trocado de lugar! A menina narrando saudade de um tempo sem data, e a vó se lambuzando naquele instante! Quando viu, tava toda envolta nas suas próprias saudades... desatou a confidenciar pra menina tudo quanto é tipo de lembrança mofada, esquecida nas gavetas da memória sem uso. E cada uma que a vó puxava daquele baú do tempo, virava presente no olhar instante da menina! $E$ assim elas iam invertendo a lógica fria do sentido das coisas... Quem visse de frente, podia reparar que a cara das duas tinha o mesmo semblante... cada uma testemunhando uma contagem diferente do tempo... Naquilo a vó caiu em compreensão de que o medo que a menina tinha, era um medo que também morava nela. Aquele medo 
do breu da noite, era o medo do breu do esquecimento. De ir se acostumando no tempo dos relógios, das máquinas e das panelas e ir esquecendo, assim..., da origens das coisas... das gentes... de ir desaprendendo de imaginar... Aquela espécie de saudade, então, era um jeito de não esquecer? Naquela noite $e$ na outra e em todas as outras que se seguiram... a menina não chorou, não... Chorar agora só de dia e por motivo besta, mesmo. Porque à noite a menina e a vó embarcavam na mesma viagem e rumavam a cara na brancura da Lua... A vó ia pegando gosto em saudadear e de tanto lembrar começou a temperar as verdades com umas invencionices que iam servir pra dar nome às saudades sem porquês da menininha. Ali naquele toco, de cara pro clarão da Lua, as duas se faziam em muitas, a voz de uma se misturava nas vozes de tantas... que agora todas as histórias do tempo passavam por ali, lumiando a noite, botando claridade no breu do esquecimento...

A narrativa se apresentou no nosso espaçotempo de cocriação com muita força poética, ressoando de maneira muito coerente em todas nós. Um daqueles momentos do sistemaprocesso em que algo se materializa em forma e todas reconhecemos e confiamos que aquilo que se modelou deve ser encarnado. Ela não era somente uma fabulação de uma narrativa pessoal, mas trazia muitos sentimentossemsentidosreflexóessentidos que vínhamos ao longo do sistemaprocesso entrando em contato, maturando, quase uma síntese de muitas das nossas vivências. Janaína modelou em palavras algo da suanossa experiência do sistemaprocesso.

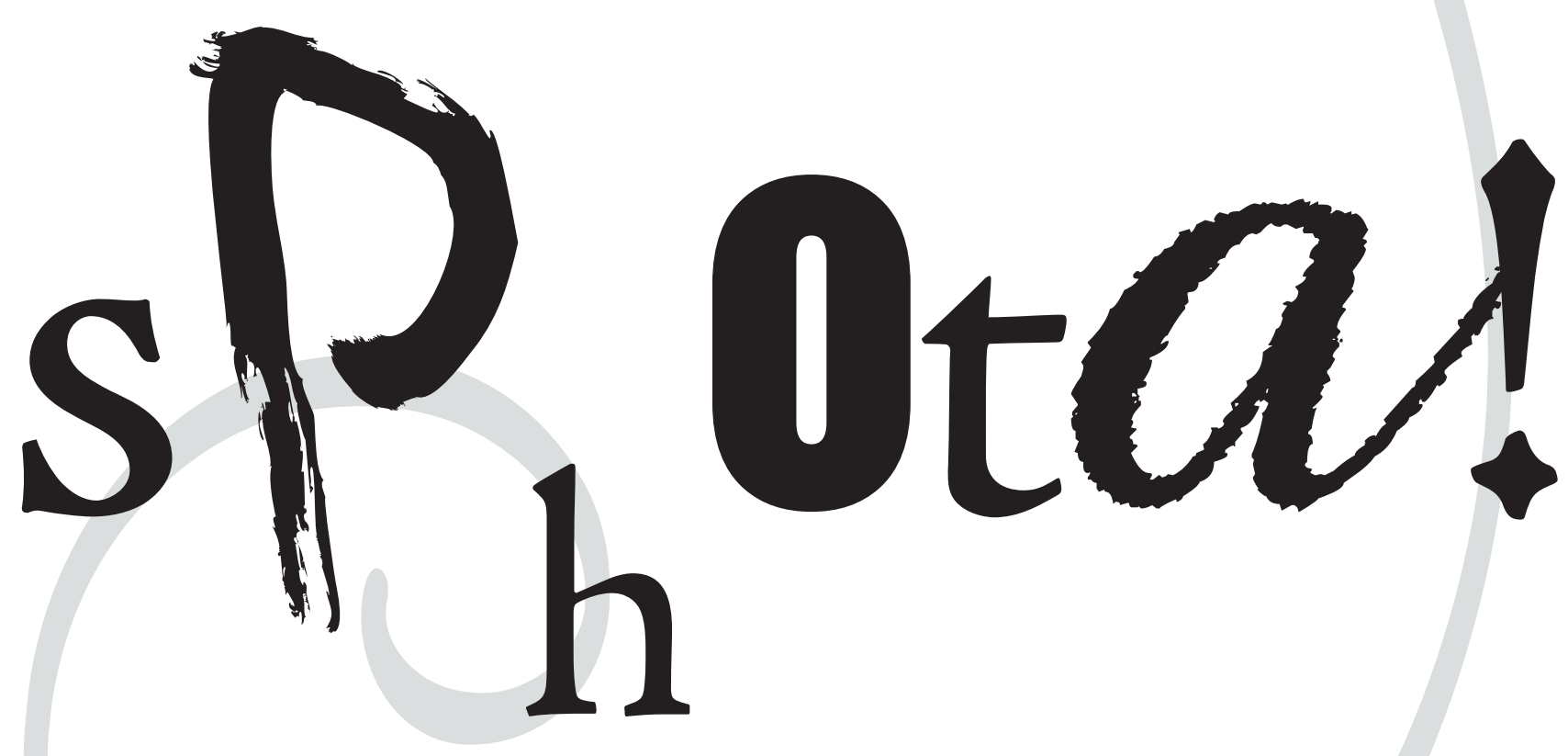

Não tivemos dúvidas de que essa seria a narrativa fabulada para realizar o trânsito da célula Infância. Escolhemos então a minha narrativa do Pé de Chupetas para fazer a instância da memória.

Rascunhada a proposta de fazer a pergunta ao público (atualidade) e fazer o trânsito entre a narrativa pessoal lembrada (memória) e a narrativa fabulada (imaginação), partimos para a prática. Sabíamos também que precisávamos experimentar a proposta da pergunta ao público com pessoas no círculo. Mal podíamos esperar para esse momento! Antes do encontro com o público, suamos a proposta de célula e o trânsito entre as narrativas... Nesse primeiro momento, ainda fazíamos o trânsito sentadas nos banquinhos, que ficavam na borda do círculo. 


\title{
Conversas pobre andamentos da dramaturgia cênica...
}

\author{
Pnstância Infância:
}

- Momento de ouvir a voz do público, de um gesto passa pi a fogo do - Transito entre fabulaça da lua e Depoimento da Chupeta.

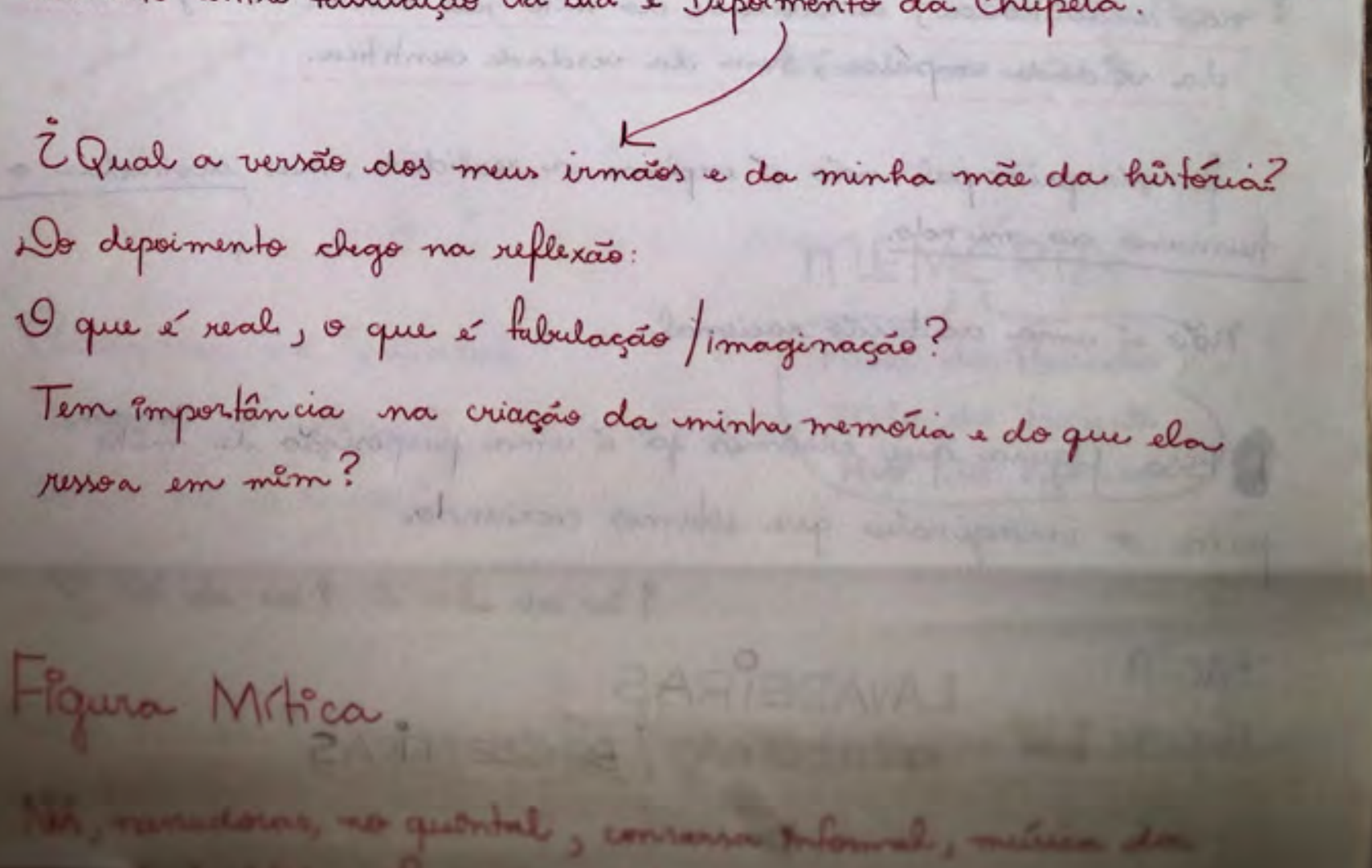

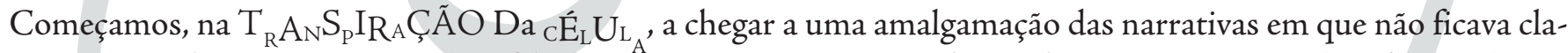
ro o que era depoimento pessoal ou fabulação, se a narrativa era minha ou da Janaína, se era real ou ficcional. Isso nos interessava. Assim, acredito, conseguíamos partir de nós, das nossas narrativas, e chegar às problematizações que a peça propóe, sem ficarmos no universo egocêntrico das nossas narrativas pessoais e sem criar um ambiente nostálgico de rememoração de memórias pessoais.

Das improvisações nos ensaios, surgiu uma QUAそTA escrita, em que organizei numa dramaturgia cênica os movimentos corporaisvocais que surgiram das nossas experimentaçóes. $\mathrm{O}$ meu caderno de infância iniciaria a célula.

Junto com o caderno, uma música suave e terna composta por Alencar (a partir do experimento citado acima, em que improvisamos movimentos corporaisvocais de infância e música) e um movimento que convidaria o público a ver o caderno em minhas mãos, iniciavam a cena. Nesta quarta escrita, propus fixar os momentos de trânsito entre a narrativa da chupeta, narrada de maneira coloquial, e a narrativa da Lua, fabulada. Sugeri ainda fixar os movimentos corporaisvocais ou palavras que seriam repetidas para entrelaçar uma narrativa à outra. 


\section{QUARTAESCRITA: AS CHAVES DA MEMÓRIA}

\section{(escrita por Renata Vendramin)}

(R pega o caderno de tarefas do varal. Abre. Quando abre, Alencar começa a tocar o violão. A abertura do caderno abre o portal das histórias da infância, da Infância da memória, as histórias da infância são as chaves que começam a despertar a nossa memória. $R$ mostra o elefante para o público, fecha o caderno, música cessa. $R$ pergunta para o público.)

$R$ : Onde é que estão guardadas as histórias da sua infância? Onde você acha que elas foram parar?

(Atrizes conversam com o público, falando suas impressões e escutando as do público.)

Renata pega algum movimento feito por alguém do público e transforma no movimento das chupetas: uma esfrega no nariz, outra na boca. Começo do TRÂNSITO.

$R$ : Teve uma época, quando eu era criança, que eu chupava duas chupetas. Na verdade eu chupava uma e a outra eu esfregava no nariz.

E assim passavam os dias, era assim que eu dormia... Começava a dormir com as duas: uma chupando a outra esfregando...

\section{(TRÂNSITO: J pega o som do chupar a chupeta e trans- forma no choro-manha.)}

J: Diziam que aquela menina era entristonhada de outras vidas, já! E! A menina era tinhosa demais pra dormir... tinha olheiras enormes, não durmia nem com reza. Tinha espanto do silêncio da noite! E isso dava motivo pra todo tipo de explicação médica: "Isso dá é mau olhado, vizinha! Bom cuidar com chá de carqueja!" "Ah! Obra do ruim, viu? Coisa boa na outra vida a sujeitinha não deve ter feito..." " "A pessoa, quando não consegue dormir, é que não tá em paz com a consciência!" - Mas a menina só tem quatro anos!?! - "Ué?! E desgraça tem idade? Já acompanha de outras vidas..." Inda se fosse só a insônia! Mas bastava dar seis da tarde, o sol saía, e a tristeza da menina chegava! As galinhas iam se empoleirando pra dormir, e já batia o desespero na coitada! Era a natureza trocar de dono, que a menina garrava num choro descontrolado que espantava todo mundo! (Choro.)

(TRÂNSITO: $R$ pega o choro e transforma no movimento das chupetas.)

R: ... até que de repente a do nariz caía, aí, dali a pouco o sono embalava profundo e a da boca também caía. Quando acordava no outro dia, tinha que sair caçando as chupetas debaixo da cama. Nessa época eu tinha 4 anos, e eu sou a filha caçula de três irmãos. Lá em casa a gente é escadinha, minha mãe teve um atrás do outro, a gente tem uma diferença de 2 anos de idade. 0 meu irmão mais velho tinha 8 anos, minha irmã do meio 6 , e eu 4 . E os meus irmãos mais velhos já iam pra escola à tarde. De manhã a gente brincava juntos, e à tarde eu ficava sozinha em casa. Era muito chato! Muito chato. Na hora do almoço já começava a ficar chato, meus irmãos tomavam banho, colocavam o uniforme da escola, arrumavam a mochila, cheia de tápis, cadernos... e comigo não acontecia nada... Chato! Aí eu pedi pra minha mãe, pedi pra minha mãe pra ir pra escola. Todo mundo ia, por que é que eu tinha que ficar em casa? Minha mãe adorou a ideia! Só que tinha um problema, um problema grande! (Movimento chupetas.)

\section{(TRÂNSITO: J pega o som das chupetas e transforma no choro-manha.)}

J: E nada dava jeito! A vó uma vez ficou sabendo de um velhinho benzedor que curava de um tudo e levou a menina: o velhinho olhou, pôs olhos de bom senso... $e$ antes de receitar qualquer mandinga... agachou até a medida miúda da menina, olhou de igual pra igual, encontro de alma antiga... alma com alma, no profundo do olhar... e lá no meio da bola preta do otho, foi dar de cara com o espanto, aquele monstro que não deixava ninguém dormir! "Onde dói?" A menininha tinha o coração disparado; mas, sem que ela mesma tivesse tempo de enfiar a cara no suvaco da vó, a boca abriu primeiro! Falou, apertande o peito: "É por aqui, assim..." E como é que é a dor? "Dói uma dor de antes! De quando eu morava lá, com ela..." E apontou, na janela, a Lua, que tava cheia, gorda, pesada, fazendo um clarão na consciência... A vó se arrepiou feito gato e soltou uma palaura mal emendada na outra, tentando virar frase: "... a primeira palaura que ela aprendeu a falar foi Lua!" Equem é que ia duvidar que a menina tinha mesmo vindo de lá? $O$ benzedor deu a receita: "É dor de saudade! Toda vez que ela chorar, bota pra vê a Lua!" A menininha, como se tivesse tomado xarope colorido de pronto efeito, esmiuçou um sorriso miúdo no canto da boca. A receita da alma antiga era... doce! A vó pegou firme no pulso da menina, fez que sim com a cabeça e desse mesmo jeito tomaram o rumo da rua... O pescoço dançava um sim mas na cabeça, envolta numa esquisitice de 
pensamentos, dançava uma desconfiança: "Saudade... Saudade de quêe? E criança lá tem saudade?" Nas obviedades daquela cabeça adulta, criança era criatura que só colecionava instantes, só tinha compromisso com o agora... memória de criança vive de minutos! Mas a da menina, não. Deu pra guardar saudades sem idade e ainda por cima de uma esquisitice de ter morado na brancura da Lua. Mas se pra curar aquele berreiro era só botar a menina pra ver a Lua boiando no breu da noite... que mal tinha lambuzar 0 dedo naquele devaneio? Pra que contrariar?

\section{(TRÂNSITO: R repete: Pra que contrariar?.)}

R: Pra que contrariar? Me diz! Pra que contrariar? A menina tava pedindo, não queria ficar sozinha, sem ninguém pra brincar. A mãe, a minha mãe, aceitou 0 meu pedido. Mas tinha um problema: as chupetas. Não dava pra ir pra escola segurando duas chupetas. Tava na hora de largar as chupetas. E agora? Que fazer? Precisa largar, mas também não dava pra arrancar as chupetas da menina, no caso eu, e jogar no lixo, queimar, e me deixar chorando desesperada, eram as minhas companheiras de dia, de noite, de embalar sonhos. A minha mãe teve um ideia brilhante, daquelas de mãe que é guardiã de filho, e sugeriu:

- Renata, vamos plantar as suas chupetas no quintal pra nascer um Pé de Chupetas?

Um Pé de Chupetas?!? Aquela foi a melhor proposta que eu tinha ouvido desde que eu nasci. Se eu fechar os olhos neste instante, eu me lembro o Pé de Chupetas que eu imaginei naquele dia. Na mesma hora fomos pro quintal os cinco... (Levanta, movimento de dar o passo.)

\section{(TRÂNSITO: J levanta, faz movimento de dar o passo.)}

J: Quando as duas apareceram na ponta da rua, 0 Sol já tava baixo, enrolando pra ir embora, só pra dar tempo das duas chegarem em casa. "E lá vem a noite..." A menina já começou a ficar encruada, formando cara de choro, quando a vó parou no portão da cảsa e sugeriu sentarem no toco. "Borá ver a Lua?" A menina se alegrou "Eu conheço lá, vó! Já fui sozinha até o pé da Lua e voltei! O vó, você sabia que quando você viaja de trem, de carro, de metrô, de ônibus, a lua vai junto, e chega até antes, você sabia?"

(TRÂNSITO: R repete: Você sabia?)

$R:$ Você sabia que, se você plantar sua chupeta no quintal, nasce um pé de chupetas, se você tiver duas então... Fomos os cinco pro quintal debaixo do pé de goiaba: o meu irmão mais velho, a minha irmã do meu meio, eu, a minha mãe e o nosso cachorro. Em uma das mãos eu tinha uma colher de sopa; na outra, as duas chupetas. Comecei a cavar o buraco. (Movimento de cavar.) Aí eu dei uma olhada pro lado e vi um sorriso de canto de boca na cara dos meus dois irmãos mais velhos e os olhos deles diziam: bobinha!, eu achei meio estranho, mas não dei bola, continuei a cavar o buraco. Eu só pensava no Pé de Chupetas.

\section{(TRÂNSITO: J pega a atmosfera do encantamento.)}

J: Aquela conversação soava tão fresquinha e inocente nos ouvidos, que a vó esqueceu da hora da janta e se alimentou de vez naqueles devaneios... parece até que tinha trocado de lugar! A menina narrando saudade de um tempo sem data, e a vó se lambuzando naquele instante! Quando viu, tava toda envolta nas suas próprias saudades... desatou a confidenciar pra menina tudo quanto é tipo de lembrança mofada, esquecida nas gavetas da memória sem uso. E cada uma que a vó puxava daquele baú do tempo, virava presente no olhar instante da menina! $E$ assim elas iam invertendo a lógica fria do sentido das coisas... Quem visse de frente, podia reparar que a cara das duas tinha o mesmo semblante...

\section{(TRÂNSITO: R repete: quem visse de frente.)}

$R$ : Quem visse de frente podia ver ali os quatro (irmãos, mãe, cachorro) cúmplices daquele momento. Terminei de cavar o buraco, coloquei as chupetas, antes dei um beijinho, e tampei. $E$ aguei. Naquela noite...

\section{(TRÂNSITO: J repete: naquela noite.).}

J: Naquela noite cada uma testemunhando uma contagem diferente do tempo... Naquilo a vó caiu em compreensão de que o medo que a menina tinha, era um medo que também morava nela. Aquele medo do breu da noite, era o medo do breu do esquecimento.

\section{(TRÂNSITO: R repete: e no breu daquela noite.)}

R: E no breu daquela noite, eu senti falta das minhas chupetas, das minhas companheiras de dia, de noite, de embalar sonhos. Minha mãe disse que foi me espiar, eu rolava na cama, mas não pedi pelas chupetas, em nenhum momento pedi pelas chupetas. Tudo em nome do Pé de Chupetas que ia nascer no 
meu quintal. A minha mãe disse que durante uma semana eu aguei todos os dias as sementes de chupeta, esperando por um broto de árvore. (Faz movimento de aguar.)

\section{(TRÂNSITO: J faz o movimento de aguar e transforma.)}

J: Um medo de ir se esquecendo. De ir se acostumando no tempo dos relógios, das máquinas e das panelas e ir esquecendo, assim... da origens das coisas... das gentes... de ir desaprendendo de imaginar... Aquela espécie de saudade, então, era um jeito de não esquecer? Naquela noite e na outra e em todas as outras que se seguiram... a menina não chorou, não... Chorar agora só de dia e por motivo besta, mesmo. Porque a noite a menina e a vó embarcavam na mesma viagem e rumavam a cara na brancura da Lua... a vó ia pegando gosto em saudadear e de tanto lembrar começou a temperar as verdades com umas invencionices que iam servir pra dar nome às saudades sem porquês da menininha. Ali naquele toco, de cara pro clarão da Lua, as duas se faziam em muitas, a voz de uma se misturava nas vozes de tantas... que agora todas as histórias do tempo passavam por ali, lumiando a noite, botando claridade no breu do esquecimento...

(As duas repetem juntas, sobrepondo vozes.)

R: Um pé de chupetas!

J: A unuuuuuaa!

Fomos então ao encontro com o outro, ampliando a cocriação:

\section{Faixa 30}

DVD 02 / Faixa 30

Neste vídeo da Faixa 30, experimentávamos uma primeira proposta de figurino e trabalhávamos com uma proposta de dramaturgia cênica em que os objetos que "puxavam o fio das histórias", que traziam as narrativas para o espaçotempo da peça, ficavam dispostos em um varal, e pedíamos a alguém do público que escolhesse um dos objetos. Dessa maneira, a sequência narrativa (a ordem das células) seria escolhida pelo público. Todos esses movimentos de cocriação aconteciam simultaneamente, em rede.

Às vezes uma palavra nova que surgia em algum textopalavra ressoava na escolha de um figurino, a presença de um novo objeto influenciava a cocriação de uma sonoridade, um movimento corporalvocal compartilhado modificava a dramaturgia cênica.

\section{O SiSTeMaProCeSSo DANÇAVA, MOVIMENTOS DE COCRIAÇÃ O, EM REDE.}

Depois desse encontro com cocriadores, assentando e deixando ressoar as percepções deles, resolvemos também nessa célula sair dos banquinhos que ficavam na borda do círculo e ocupar o centro da arena. O iamá (o nosso iamá), que foi uma prática essencial no início do sistemaprocesso, que se desdobrou em dois, neste momento não parecia coerente estar em cena, parecia segurar a evolução da célula. A nossa relação com o banco não estava contribuindo para o amadurecimento da nossa presença em cena; e não era somente nessa célula da peça, mas em todas as que estávamos experimentando naquele momento.

Ainda nesse encontro com cocriadores, tivemos a confirmação de que fazer a pergunta para o público era muito valioso neste momento; poderia, sim, ser um recurso eficaz para trazer outras vOZES (que desde sempre desejamos!) para o encontro teatral. Nosso desejo era que a COcRIAÇÃ $O$ seguisse durante a vida da peça, sempre viva, 
que não se encerrasse quando ela ganhasse contornos artísticos. Se o desenho da peça ficasse engessado, deixasse de pulsar, não faria sentido, não seria coerente com todo o sistemaprocesso.

\section{CADERNO DE RELATOS III}

A poesi (Relato de Renata Vendramin, 14 de outubro de 2013)

Como público, olhando nos olhos de quem ali estava, senti as pessoas percorrendo seus puónios caminhos, tecendo suas trajetorias, se sentindo a rede, se imocionando. e nos momentos de mais singeleza, poesia que sinto se abrindo. os portais do novo, onde a pessoa se encontra consigo Amesma, reariva sua coragem, confranca, crenca na vida, se sente capaz de assumir a escrita de sua propria história. a críagöos dos suns terscitoicios

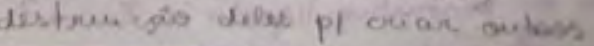

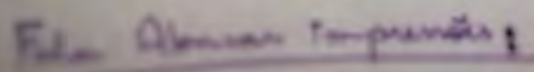

Arejadas com o encontro de cocriação, felizes com a descoberta do início da célula, e de como esse começo ressoava no público, voltamos a transpirar a célula. Decidimos tirar os banquinhos da borda do círculo. Eles não existiriam mais. Estava uma atmosfera muito boa, tudo ao nosso favor pra mergulhamos na célula, foi então que...

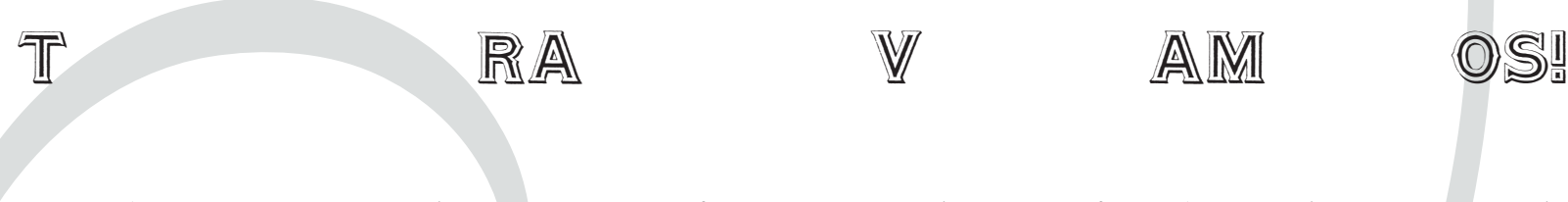

Ficamos, durante alguns ensaios, travadas! Os trânsitos ficaram enrijecidos com a formalização dos momentos de troca entre uma história e outra, perdemos totalmente o frescor das narrativas. A narrativa da Lua fabulada, ainda em processo de memorização, não conseguia materializar poesia no corpovoz. A narrativa da Chupeta, narrada de maneira coloquial, perdeu o seu tom cotidiano, banal, simples; estava se misturando com o tom da narrativa fabulada. Ambas estavam virando a mesma coisa, perdendo o contraste das atmosferas que interessava na célula para o trânsito MEMÓRIAIMAGINAÇÃOATUALIDADE ser encarnado. E nós duas, com tudo isso, ficamos irritadas com o que estava acontecendo.

Estávamos nesse ponto do sistemaprocesso, em um momento delicado de passagem dos experimentos livres para a formalização da célula, a memorização de um textopalavras fixo, de trânsitos definidos e, além de tudo, estávamos em pé! Completamente expostas na arena, sem banquinho pra sentar. D QUE FAzER?

\section{R E S P I R A M O S ! R E S P I R A M O S JUNTAS...}

...as nossas irritações, os nossos bloqueios, as nossas travas... e quanto mais conseguíamos respirar juntas, cada uma as suas dificuldades, sem projetar na outra, melhor. Nem sempre conseguíamos... 
deles estäo mais bibertas. Hoje no ag

CADERNO DE RELATOS IV

Bonito!

(Relato de Renata Vendramin, 05 de novembro de 2013)

- Partimos para a Infância novamente, no ensaio passado tinha sido um bode esta cena, a terto näo estava memorizado, tinham um bloqueios, uns receios, uma viritaçäo, tava difícil... hoje fluiu tbrm, nossa presença tava aberta pra se arriscar, pra ouvir o outro, pra ser ouvido. Cs falas ganharam ritmos $\neq s$, os movimentos mais vitalidade. Pmprovisamos algumas vezes, descobrimos jó alguns movimentos que provavelmente võo ficar, faremos mais algumas vezes. Ocupamos a curna. Deixamos de ficar só nas bordas.

Fazendo, refazendo, irritando-nos, conversando, questionando, respirando, movimentando-nos, fomos reconhecendo que definir os momentos dos trânsitos entre as narrativas e marcar os movimentos corpovoz enrijeciam o jogo. Janaína propôs de deixarmos os trânsitos acontecerem no improviso, na escuta. Definimos ainda que a narrativa da Chupeta não seria narrada sempre do mesmo jeito; existia um trajeto dramatúrgico a ser percorrido, e eu poderia realizá-lo de diferentes maneiras, ficando aberta para o improviso; e que Alencar e Gabriel (o outro ator que cocriava a música conosco neste momento do sistemaprocesso) improvisariam a música durante a narrativa da Lua fabulada, ajudando a cocriar e distinguir uma atmosfera da outra, pelo menos no início da célula - pois, caminhando para o final, a intenção era que as narrativas se misturassem e até se confundissem em seus limites, sem que se soubesse onde terminava uma e começava a outra.

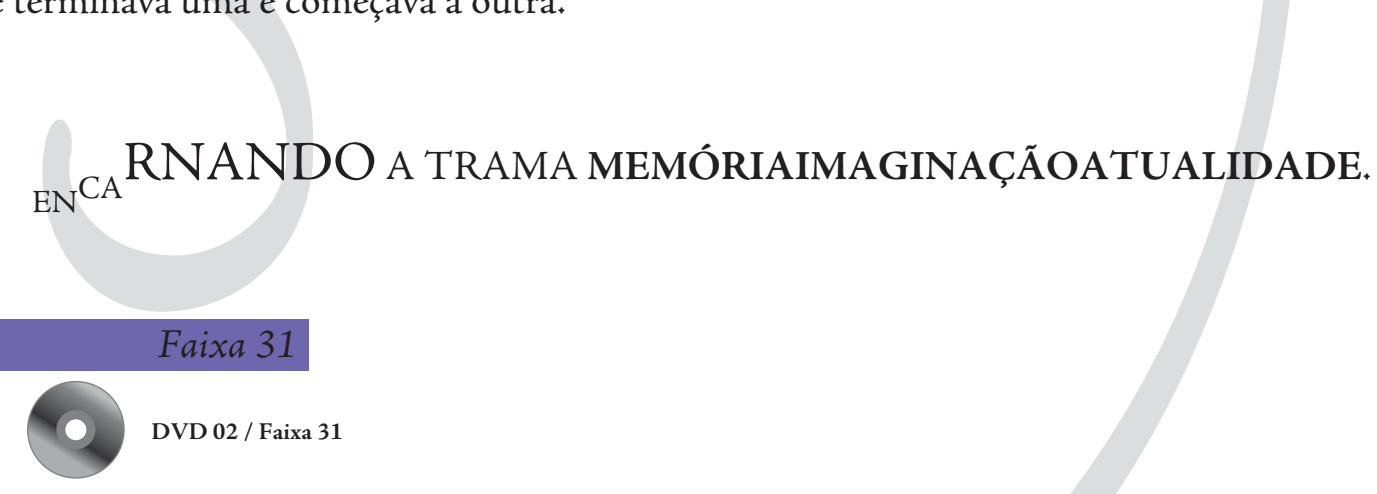

$\mathrm{Na}$ abertura de processo da peça, em dezembro de 2013, a fala das pessoas era unânime em relação à célula Infância. Para muitos, a peça acontecia a partir dali, toda a dramaturgia cênica que havíamos percorrido antes era desnecessária. Seguidas da célula Infância estavam a célula Imaginamentos ${ }^{57}$ e a célula Música Instrumental $A$ Próxima História. ${ }^{58}$

${ }^{57}$ Entrelaçamento com o texto da página 168.

${ }^{58}$ Entrelaçamento com o texto da página 174. 


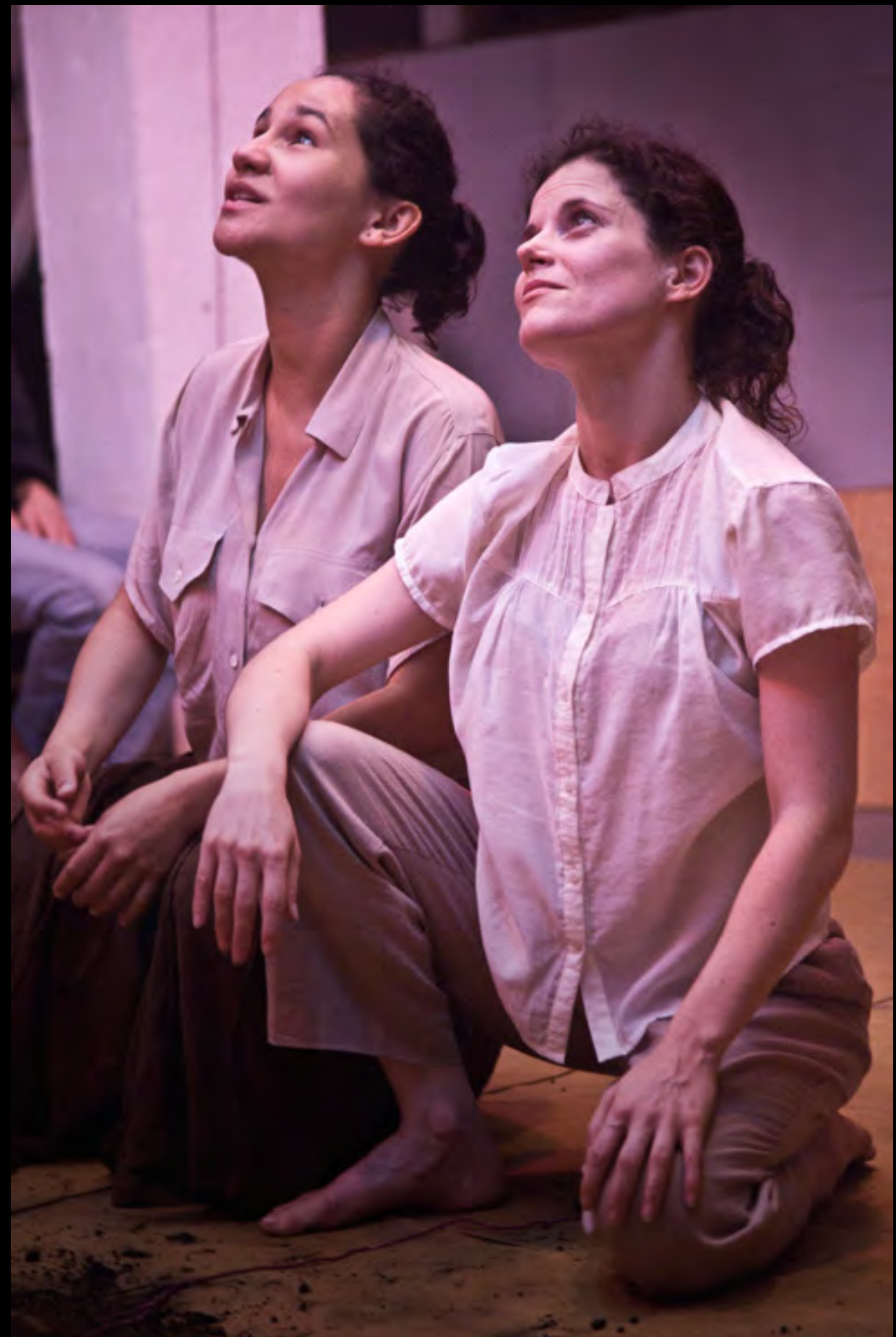

Figura 11. Abertura de processo da peça, dezembro de 2013. Foto: Tide Gugliano.

Quando iniciamos o segundo ciclo do processo, em 2014, mantive esse sentimento de que a célula Infância e as outras duas células que se seguiam existiriam na peça. Alencar estava de acordo.

O primeiro trabalho da retomada da célula foi a memorização do textopalavras da narrativa fabulada. Foi um trabalho solitário para encarnar todas as palavras, respeitando o texto na íntegra. Comecei a relacionar-me com ele sozinha e, aos poucos, suando-o também nos ensaios junto com Alencar, fui encarnando-o.

Senti vontade ainda de retomar o banquinho, trazê-lo agora para o centro da arena. O nosso iamá retornou materializado em cena, pois, apesar de não estarmos mais trabalhando com ele como presença física até a abertura de processo, o conceito do iamá esteve sempre presente, como se todos nós que compuséssemos o círculo da peça estivéssemos sentados em nossos iamás.

Em princípio eu mantive o banquinho que já utilizávamos, e com a chegada da diretora de arte, Marisa Rebollo, conseguimos trazer um pequeno toco de madeira para o centro da arena. 
"Nosso Pai Primeiro

criou-se por si mesmo

na Vazia Noite iniciada.

As sagradas plantas dos pés,

o pequeno assento arredondado

do Vazio Inicial

enraizou seu desdobrar (florescer).

Círculo desdobrado da sabedoria inaudivel,

fluiu-se divino Todo Ouvir

as divinas palmas das mãos portando o bastão de poder,

as divinas palmas da mãos feito ramas floridas

tramam o Imanifestado, na dobra de sua evolução,

no meio da primeira Grande Noite.

Da divina coroa irradiada

flores plumas adornadas

en leque.

Em meio às flores plumas floresce

a coroa-pássaro

do pássaro futuro,

luz veloz

que paira

em flor e beijo,

que voa não voando.

Nosso Pai Primeiro criava

futuro colibri, no curso de sua evolução, seu divino corpo.

Existia no entanto em meio aos primeiros Ventos Futuros

como coruja dentro da Noite Primeira

olhava-se, revoando

seu futuro firmamento, sua futura terra,

brisas surgidas

enquanto colibrizava vidas

dos ventos produzidas do Imanifestado que fora:

Nosso Pai, O Grande Mistério, o primeiro,

Antes de haver-se criado,

no curso de sua evolução,

sua futura morada,

sustenta-se no Vazio.

Antes que existisse sol.

ele existia pelo reflexo de seu próprio coração

e fazia-se servir de sol dentro de sua própria divindade.

$O$ verdadeiro Grande Espírito, o primeiro,

existia diante dos ventos primeiros

de onde ancorava-se no vazio-noite

feito coruja produzindo silencios.

E fez que se gir assem as manifestações de si diante da noite, vestido de espaço.

Antes de haver o verdadeiro Pai, o Uno,

criado no curso de sua evolução, sua morada,

antes de haver criado a Terra Primeira,

existia em meio aos primeiros ventos:

e o Vento Primeiro de nosso Pai podemos percebê-lo como espaço-tempo,

onde ao fim deste Vento,

nomeou-he: época, era, (h)ora.

Orou, arando rios de tempo-espaço,

desaguando novos ventos, os espaços novos,

defloram e florescem

a flor de cada época.

("Os primeiros costumes do colibri". In: JECUPÉ, 2001, p. 25. Grifos meus.) um colibri.

O pequeno toco de madeira seria, de maneira poética, esse pequeno assento arredondado do Vazio Inicial, que, ao fluir divino do todo ouvir, desdobra-se (floresce) em manifestações, deságua em novos ventos, deflora novos espaçostempos. Ali, no centro do espaço cênico circular, o pequeno toco passa a ser o lugar onde me assento e inicio a cocriação da peça.

Figura 12. Primeiro dia do toco na cena. Foto Renata Vendramin.

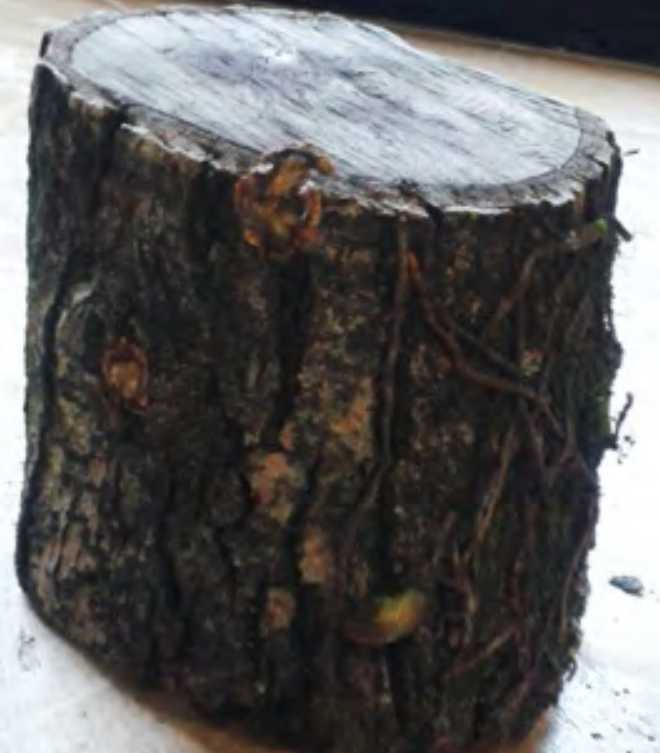


Mas, no período de maturação da célula, o toco era ainda um pequeno banquinho de madeira. Trabalhei sozinha em alguns ensaios com as duas narrativas separadamente e fiz junto com Alencar a primeira experiência de transitar entre as narrativas. Ainda estávamos investigando se a cena aconteceria comigo sozinha fazendo as passagens.

Faixa 32

DVD 02 / Faixa 32

A experiência mostrou que poderia ser interessante eu realizar, sozinha, o trânsito entre as narrativas. Para isso, precisávamos trabalhar os detalhes e as sutilezas das passagens. Essa célula nos trouxe um desafio particular, pois ela já existia na abertura de processo, com essa mesma estrutura, e agora precisávamos modificar alguns detalhes e, ao mesmo tempo, estabelecer outra relação com ela, sem querer que fosse o que era antes.

Em alguns momentos, pegamo-nos agarrados a detalhes e elementos que já não faziam sentido existir na célula neste novo ciclo - como, por exemplo, alguns movimentos que Janaína fazia enquanto narrava a história fabulada e, no início da minha relação com o textopalavras, eu reproduzia de maneira inconsciente. A música improvisada por Alencar na narrativa fabulada parecia não ser mais coerente agora; no entanto, mesmo assim, nós experimentamos muitas vezes diversas possibilidades de a música acontecer na cena, até reconhecer e aceitar que a musicalidade estava nas palavras que eu narrava. Nos dizeres de Alencar: "a música nesta cena é uma coisa da outra peça".

Experimentamos todas as possibilidades que surgiu no espaçotempo de cocriação e chegamos à proposta que foi apresentada ao CEPECA com todo o desenho dramatúrgico da peça. Neste dia, já havia feito alguns pequenos cortes e pequenas modificações no texto: agora começávamos a célula com a narrativa fabulada, que vinha em

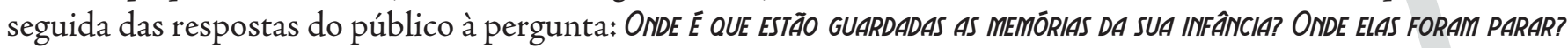

Antes de começar o ensaio compartilhado no CEPECA, atravessou-me a ideia de trazer a máscara que estava usando na célula $A$ Mais Velha que o Tempo para fazer a figura do benzedeiro que ajudava a menininha na fábula. Ouvi e deixei passar... No final da apresentação, no momento do Círculo de Falas, em que compartilhamos as ressonâncias do encontro, o Prof. Armando Sérgio sugeriu:

\section{POR QUE VOCÊ NÃOTRAZ A VELHA PRA CENA DA MENINA?}

Ele queria relacionar-se com a velha de novo, não somente na célula inicial. Assim como ele, outras pessoas também queriam. Assim, o velho benzedeiro do texto original, escrito pela Janaína, transformou-se na VELHA BENZEDEIRA, e eu comecei a trazer a máscara para esta célula. A máscara acabou, depois, indo também para a célula seguinte: Imaginamentos. Começamos, a partir do compartilhar com o CEPECA, a trabalhar com a repetição e a reposição de elementos e movimentos corporaisvocais em diferentes células, uma ideia que já estava presente, contudo era o momento de encarná-la em detalhes e sutilezas.

\section{Faixa 33}

\section{DVD 02 / Faixa 33}

Com as escolhas feitas e com uma sensação de que a energia da célula estava encarnada em forma, fizemos, refizemos, fizemos e refizemos. Essa célula traz em sua estrutura, de maneira mais explícita, o trânsito memóriaimaginaçãoatualidade, e, sempre que nos encontrávamos em uma encruzilhada ou bloqueio de cocriação da dramaturgia cênica da peça, eu voltava a relacionar-me com a estrutura da célula Infância, para me alimentar deste trânsito entre as instâncias, deixar que ele ressoasse em todas as células e momentos de passagem da dramaturgia cênica. 
Quando mergulhei na escrita deste texto da dissertação, relembrando, rememorando os detalhes, os passos de cocriação da célula Infância, acompanhando a trajetória de surgimento das perguntas que moveram nossas ações de cocriação, percebi que nesta transição para o segundo ciclo eu modifiquei no texto a pergunta feita ao público. A pergunta era:

Onde é que estão guardadas as histórias da sua infância?

E eu estava fazendo (fiz na última apresentação da micro temporada que realizamos):

Onde é que estão guardadas as memórias da sua infância?

Refletindo sobre a ressonância da célula no público, resolvi mudar a palavra memórias por histórias novamente, para que a pergunta que inicia a entrada no universo da infância, no ESTADO infância, este estadoterrenofértil, de devires, de construção de novas possibilidades, outras geografias, próximas histórias, não fique estritamente ligada à memória, mas se entrelace também com a $I^{\mathrm{MAGINAÇA}} \mathrm{O}$ e a $\mathrm{A}_{\mathrm{t} u a l} \mathrm{l}_{\mathrm{d}} \mathrm{d} \mathrm{dE}$. Seguimos em cocriação, enquanto a peça estiver viva, pulsante, tiver sentidos de existir...

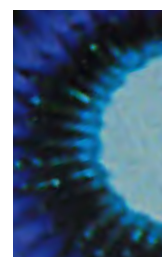

\section{CÉLULA G: IMAGINAMENTOS}

\section{Faixa $35^{59}$}

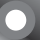

DVD 02 / Faixa 35

Do encontro com a voz de Eduardo Galeano, a partir deste vídeo compartilhado no Youtube, delineamos e fomos lapidando a pergunta que vivifica esta célula e é a perguntaguia de toda a dramaturgia cênica da peça:

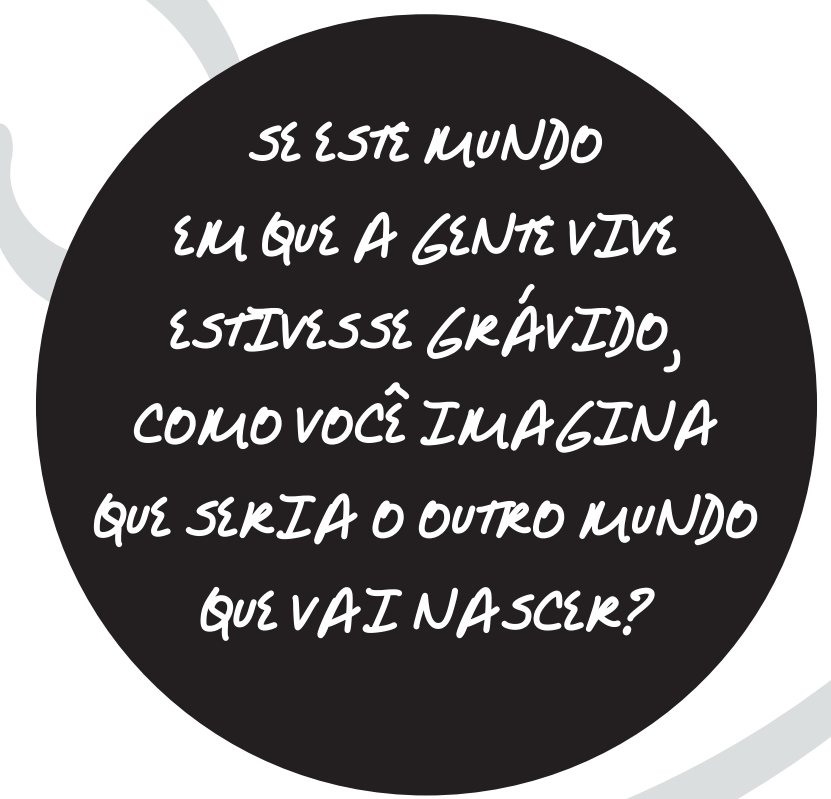

${ }^{59}$ Parte de depoimento de Eduardo Galeano, realizado na praça Catalunya, em Barcelona, ocorrido em 24 de maio de 2011. O vídeo completo está disponível em: <https://www.youtube.com/watch?v=mdY64Tdrijk>. (Acesso em: 5 mai. 2015. .) 
para a voz do público cocriar com a gente outras possibilidades de existiramarpensarsentiragirrefletir... esteve presente desde o início do sistemaprocesso. Era um daqueles desejos que são desejados por todas, no início por Janaína e eu, depois pelas outras artistascocriadoras que atravessaram o sistemaprocesso. Ainda não sabíamos como realizar isso formalmente, e muito menos como entrelaçar essas vozes, essa pLURALiDaDlE, na dramaturgia cênica. Fomos caminhando: experimentando diferentes perguntas e maneiras de inseri-las.

A vOZ DO OuTRO foi, e continua sendo, a cada apresentação da peça, condição essencial para a cocriação dessa pesquisaexperiênciaobraartística. Encontramos com vozes, durante todo o sistemaprocesso, através da colheita das narrativas pessoais, na busca por referências sonorasmusicais, textos de artistas e/ou pensadores, nos encontros de cocriação, nos nossos Círculos de Falas. E, na peça, o desejo era de entrelaçar nossas vOZ ${ }^{\mathrm{ES}}$ para cocriar a trama memóriaimaginaçãoatualidade.

A primeira fresta que se abriu para receber a voz das pessoas foi na célula Infância, e desde aquele momento (ou até antes dele), já maturávamos a ideia de, no início da peça, propor alguma ação para o público (que poderia ser uma pergunta para ser respondida), que já o instigasse a adentrar no universo que transitávamos, e, também, já deixasse claro que a sua voz seria essencial para a cocriação da peça. Quando Janaína comprou um gravador para colher depoimentos, cogitamos a possibilidade de gravar a fala das pessoas antes de começar a peça e depois colocá-las para serem ouvidas em algum momento da dramaturgia cênica. A ideia soava maravilhosa! Mas tínhamos a questão: $\mathrm{O}$ que perguntar?

Com a gestação da Janaína, aproveitando a sua enorme barriga, ela chegou a levantar a possibilidade de perguntar algo do tipo: Como seria o mundo que você gostaria pra minha filha, pros seus filhos, os nossos filhos viverem?.

Experimentamos essa possibilidade em encontros com alguns cocriadores, e um caminho começou a se delinear; porém, eu acreditava que precisávamos conseguir formular uma pergunta que ampliasse ainda mais a problematização que propúnhamos, CONVOCANDO A vOZ e $A_{\text {IMA G }}{ }^{I N}{ }^{A C ̧ A ̃ O}$ do público, e sem ficar muito atreladas à presença da barriga de grávida da Janaína, pois ela duraria até a estreia e depois disso não haveria por que manter uma barriga cenográfica na peça.

\section{BARRIGAGRÁVIDA. MUNDOIMAGINA. BARRIGAMUNDO. IMAGINAGRÁ VIDA. MUNDOGRÁVIDO}




\section{CADERNO DE RELATOS III}

(Relato de Renata Vendramin, 16 de julho de 2013)

\section{Este mundo está grávido}

de autro... Fala de Eduardo Galeano nos revisita 20

JANA está GRÁvida...

TEM

MAIS UMESSE

Nos trajetos sinuosos do sistemaprocesso a fala de Galeano já havia me inspirado a escrever um texto poético chamado $O$ Parto do Bebê-Mundo, que durante um bom tempo esteve entrelaçado à dramaturgia cênica; no entanto, em um determinado momento, antes da abertura de processo no final de 2013, decidimos que seria melhor tirá-lo da peça.

Lá ande o olko tem coracto

\section{PARTO DO BEBE-MUNDO}

Este mundo está grávido de outro;

a Toura-máe gesta seu renascimento.

Aqui nas entranhas de EAIA

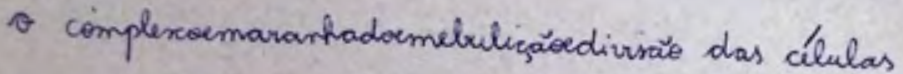

se processa, a barriga da terra se contonce na dansa do novo;

Escuta! fá é possivel ausentar a coraçăo do novo munde.

(1) cérulro está en formaçăo, thas a coraçäo fá is possivil... Escuta!

$\hat{E}$ Ciranda, $\hat{\imath}$ ciranda, abraça o novo

Tempo, vem entra na danga!

Escuta, o movimento da Mäe náo é de proussamento en śrue, de autormatismo padräe,

Muito longe de ser uma máquinia a Terra grávida geme, 
recele um ESCUTA o projeto comum da vida;

Esauta, o corasäa do belk̂-mundo pulsa sereno, compassado, trazendo os ritmos das novas músicas..

Pulsa na urgincia de pacificar-se.

Como alguím que há muito gira no TEMPO, Que nöo tem TEMPO a perder,

Que está cansado de tropecar no TEMPO.

Que năo ve sentido en covrer atrás do TEMPO

E nunca ter TEMPO pra reorer

lu mäe recriare no bebî.

(1) criadar renarce na criação.

1 Parto e' natural.

(1) Parto é, como sumpu foi, humanizado!

É humanamente humano a parto da

Escuta!

Humanidade!

É possivel auscutar $\theta$

coraçäo do bebérmundo em PAZ!

Respirando todas essas propostaspossibilidadesvozescocriaçóes, propus a seguinte pergunta para fazermos ao público:

\section{Se este mundo en que vivemos estivesse grávido de outro, comovocê imagina que seria soutro mundo que vai nascer deste?}

Com esta pergunta lançada no espaçotempo de cocriação, fomos para mais encontros com cocriadores, e para os dois dias de abertura de processo em 2013. Assim, essa célula, e toda a ressonância que ela gerou no espaçotempo de cocriação, pareceu-nos muito coerente e em sintonia com toda a experiência que vivíamos.

\section{Faixa $36^{60}$}

DVD 02 / Faixa 36

\footnotetext{
${ }^{60} \mathrm{O}$ áudio das Faixas 36 e 37 são vozes colhidas do público durante as apresentações da peça A Próxima História, na abertura de processo em dezembro de 2013 e na estreia e micro temporada em novembro de 2014, respectivamente. Aqui são trazidas, como na peça, sem que peçamos alguma autorização formal das pessoas, com licença poética, para compor uma pLURALiDaDlE de vozes. Ainda, tal como na peça, não consideramos necessário citar o nome das pessoas.
} 
As falas das pessoas ressoavam muitos desejosideiassensaçõespercepções que compartilhamos em nosso sistemaprocesso, além de expandir e diversificar a nossa experiência.

Como atriz, em cena, ouvir e respirar juntas as vozes das pessoas que se apresentam a cada dia, conduzem-me a lugares e estados que trazem novos e outros sentidossensaçõespercepçóes a cada experiência teatral. É um momento de comunhão, em que a diversidade de pensamentos, de crenças, de maneiras de existirimaginarsentir manifestam-se, sem nenhum tipo de preconceito ou julgamento. Não fazemos a pergunta esperando por alguma qualidade de resposta. A pergunta traz a oportunidade da manifestação de voZES D/vERSAS, da pLURALiDaDIE, e da ESCUTA das vozes. Como se todas as vozes do mundo pudessem ser ouvidas. Criamos um CAMPO DE DEVIREC:

\section{cheiro de noite entuarada EVPCREDITO \\ MUNDO DOBKADO FECUNDO DEPOSSIBLIDADES \\ GHIIE HO DIE IE SPAAGOS.

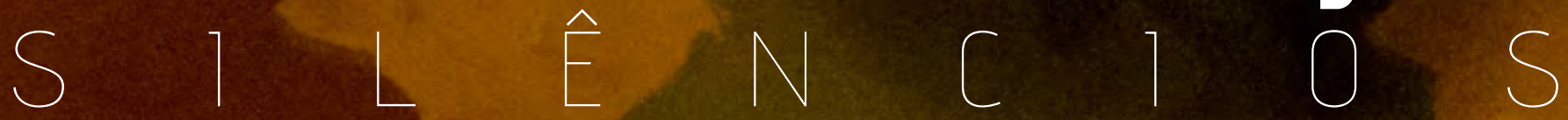

\section{GUTBOS DEYIRES RELAGIONAR-SE cou AS coISAS E}

GERAR OUTRAS SUAVIDADE COM OS OUTROS EM POSSIBILIDADES

OUTRO TEMPO

DE MUNDO MAIS

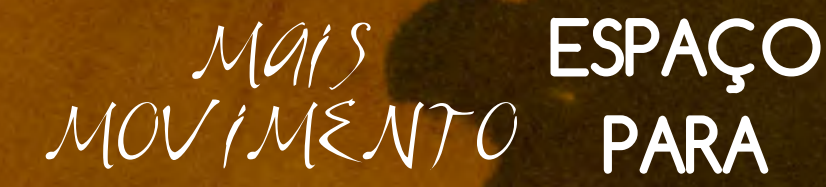

ENCONTROS

EXPERIENCI
Uma continuação deste melhorado

\section{DIVRRSO}

PARA

RESPJRAR

Com a entrada no segundo ciclo, a sequência das células: Infância, Imaginamentos e Música Instrumental pareceunos coerente para o fechamento da experiência teatral, e a pergunta, SE \&ST MUNDO ESTIVESSE GRAVIDO DE OUTRO, COMO SERIA?, passou a ser guia do trajetopoesia que é esta dramaturgia cênica. 


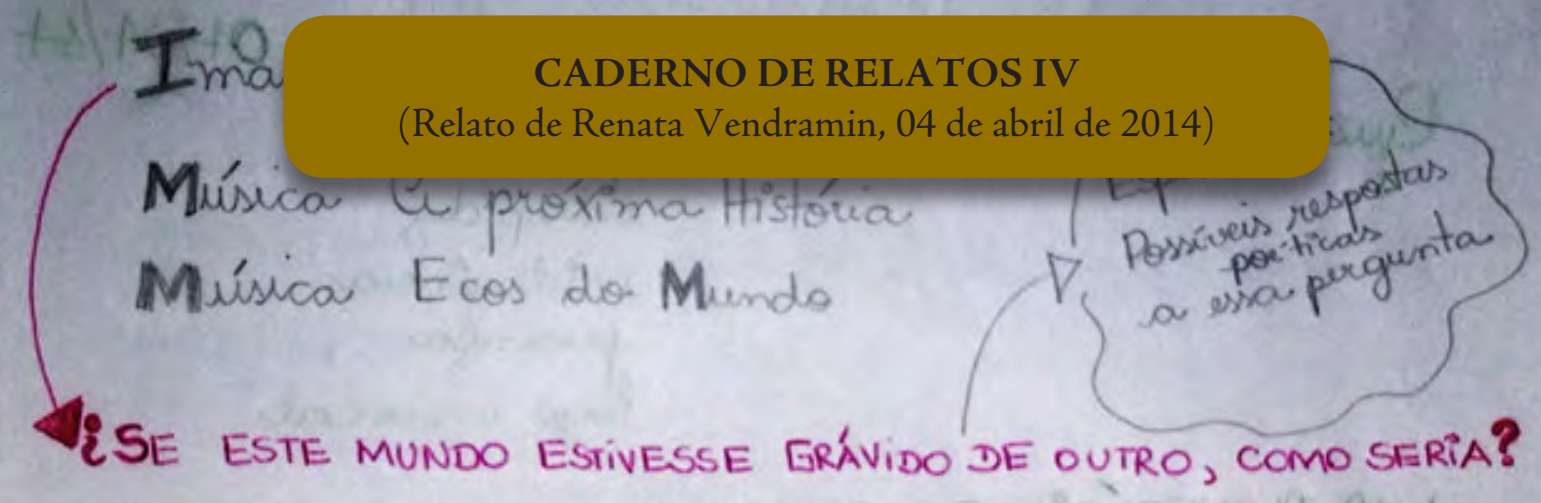

Aoredito que ussa es a frase/ que deve guiar esse'trajetoporsia'. Mexer nas nossas histórias, na nossa rede de histónas, nos fez refutir sobre MUITAS cousas e chegar (nos conectar e formular através da fala de Gallano) a ussa purgunta-poética súntese. Cocredito que issa pergunta nos lança pi a instância do imaginamento, movimenta a energia pl tranmutar e saur do lugar da estagnação e da prisáo ao passado. Sugere un exercicio saudánel, criativo, artéstico, de Imaginar!!! Usar nossa energia vital p/ imaginar! Cidiar pensamentos, a semente da agäa, que ros impulsione var novo.

Quando se apresentou a nova ordem da dramaturgia cênica, guiada por esta pergunta, fizemos ainda alguns experimentos em relação a essa célula (que se inicia na chegada do público, antes de estarmos todos em círculo acomodados, e é retomada depois, quase no final da experiência teatral):

- Dançar as vozes das pessoas e suas ressonâncias. A ideia era trazer movimentos corporaisvocais para a célula: eu dançando livremente, enquanto as vozes do público saturavam o espaçotempo de cocriação;

- Dar contornos visuais para os imaginamentos: Alencar movimentando uma lanterna virada para a lona, que delimita o espaço da cena, enquanto as vozes ecoavam;

Contudo, as duas propostas pareceram prejudicar a escuta das vozes. Era preciso

$$
\text { s } \quad \mathrm{i} \quad \mathrm{e} \quad \mathrm{n} \quad \mathrm{c} \quad \mathrm{i} \text { a } \mathrm{r} \quad \text { os OlhOS E abRiros OUVIDOS, }
$$

neste momento de ESCUTA, de RECEBER as vozes no espaçotempo de cocriação, esse momento YWN da peça, em que cocriamos um ambienteuterino para gestar nossos imaginamentos.

Quando comecei a trabalhar a repetição de elementos de cena, de movimentos corporaisvocais, de palavras e frases, durante a peça, depois do compartilhar realizado no CEPECA, em 05 de junho de 2014, naturalmente a máscara, que foi para a célula Infância, escorreu para a célula seguinte. A Mais Velha que o Tempo, retomada na figura da benzedeira, agora escutaria também os imaginamentos lançados no espaçotempo de cocriação, sentada no toco (o vazio inicial de onde tudo floresce), no centro da cena, e recolheria as... 


\section{Faixa 37}

\section{Faixa 38}

\section{CÉLULAT:}

\section{MÚSICA INSTRUMENTAL A PRÓXIMA HISTÓRIA}

Alencar, se fosse para você compor uma música que ressoasse o sistemaprocesso que estamos vivendo, os sentimentosvozespensamentossemsentidosinquietaçõespercepçõessentidosreflexões que saturam o nosso espaçotempo de cocriação, qual seria esta música?

Fiz essa propostapedidoprovocação para Alencar em um dos nossos ensaios. Isso foi aproximadamente umas três semanas antes da abertura de processo em dezembro de 2013, e já vínhamos cocriando outras músicas e sonoridades para várias células que ficaram, ou não, na dramaturgia cênica final.

Alencar, então, trouxe sua VOZ para o espaçotempo de cocriação:

\section{Faixa 39} de outras sonoridades do espetáculo, como ela surgiu no período final da criação musical, sua sonoridade é complementar e sintética a respeito de toda sonoridade que veio anteriormente. ${ }^{61}$ 
Um momento de cocriação em que, através dessa propostapedidoprovocação, integrada à vivência do sistemaprocesso, o músico Alencar acessou e usou de seu conhecimento técnico para encarnar uma música. Desde a primeira vez que ouvimos, a música mostrou-se completamente coerente e harmônica com o sistemaprocesso em sua formaconteúdo - em sua integridade.

Essa propostapedidoprovocação só nasceu porque eu sabia que Alencar tinha conhecimento e habilidades técnicas para isso, e o fato de ele ser um músico era essencial para que essa cocriação pudesse acontecer. Como atrizcriadora eu não teria condições de compor essa música e muito menos ensinar alguém a criá-la. A qualidade e a complexidade da música nasceram dessa relação de cocriação entre artistas de diferentes áreas.

Havia nessa propostapedidoprovocação que fiz para Alencar um desejo muito pulsante de trazer para a dramaturgia cênica a linguagem da música (assim como a linguagem da dança em outros momentos da peça), de uma maneira mais "pura", e colocá-la em relação com outros elementos (textofalado, gestos, sonoridades, vozcantada, elementos de cena), ou com outras células da peça, cocriando e ampliando sentidos.

A música instrumental, que se entrelaça à célula Imaginamentos na teia dramatúrgica, prolonga o T E M P O DE ESCUTA da peça. É um momento de assentarmos juntos, cada um consigo, a experiência compartilhada.

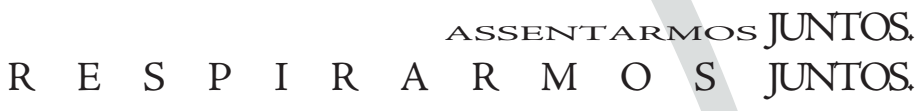

Assentar é respirar, deixar acomodar no corpovoz a experiência, para que ela não se esvaia como tantas coisas que nos atravessam, para que sentidos e semsentidos cocriem-se e assentem-se. Aqui também se instaura, assim como na célula Imaginamentos, o

\section{ESPAÇOTEMPO DE ESCUTA}

\section{ESPAÇOTEMPO DE SILÊNCIO}

ESPAÇOTEMPO DE ASSENTAR

ESPAÇOTEMPO DE RECOLHIMENTO

ESPAÇOTEMPO PARA CONEXÓES SIGNIFICATIVAS

ESPAÇOTEMPO צ্ִর

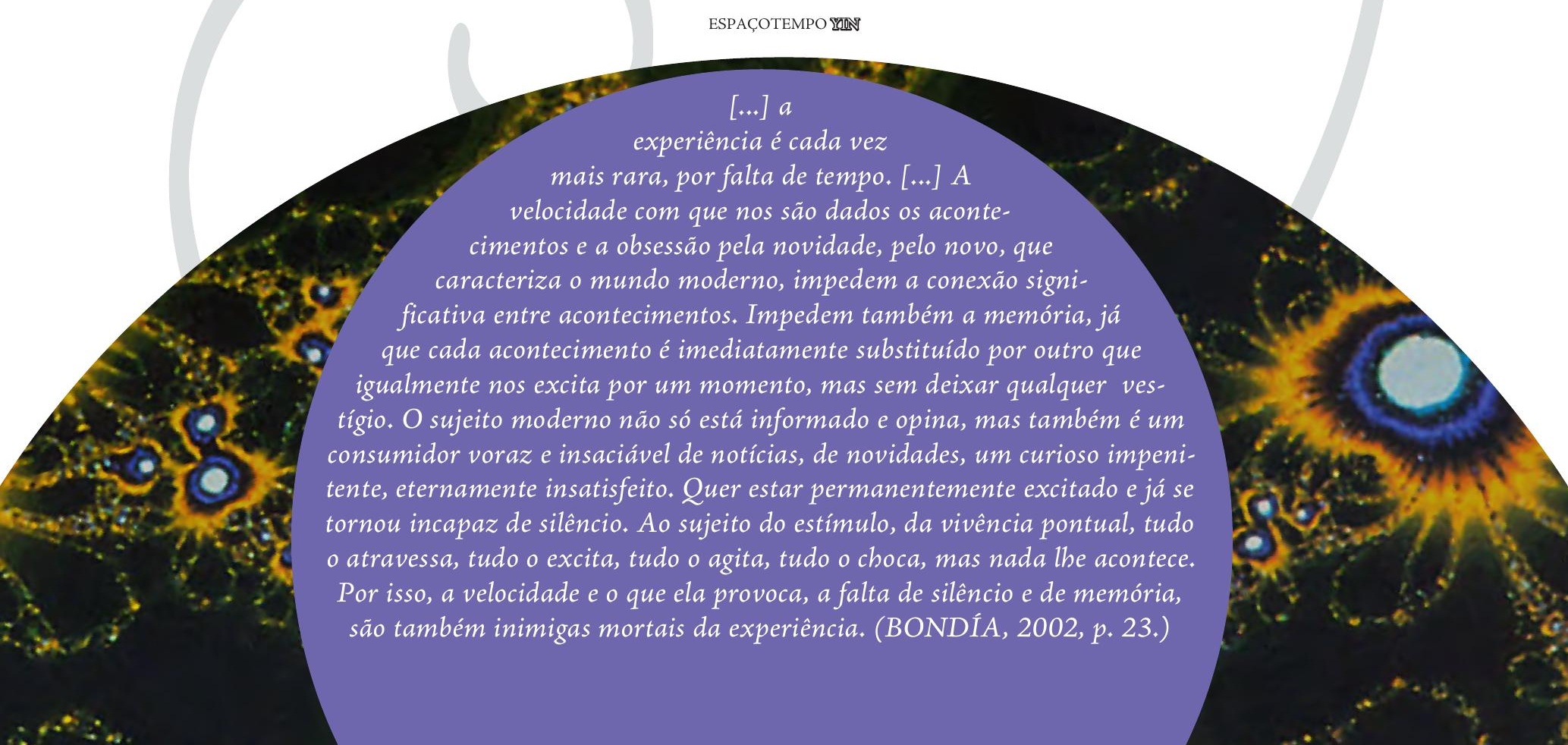


Quando adentramos esta célula na peça, estamos ainda em uma experiência compartilhada, de cocriação, olhando uns para os outros sentados em círculo (neste momento, sento-me na borda do círculo, junto com todos), e reservamos um momento, um precioso espaçotempo da peça, para respirarmos juntos, assentarmos a experiência individualmente, ao mesmo tempo em que somos sensibilizados pela música tocada por Alencar.

Em relação à evolução desta célula ao longo de todo o sistemaprocesso, desde a primeira elaboração, sentamo-nos todos na borda do círculo e ouvimos a música executada por Alencar. $\mathrm{Na}$ abertura de processo em dezembro de 2013, após a música, ainda tínhamos mais uma aparição da Figura Mítica. Depois da experiência dos dois dias de abertura, decidimos encerrar a peça com a música instrumental. Assim, no fluxo da música, deixando ressoar a experiência em nós e no espaçotempo de cocriação, encerramos o ciclo da experiência teatral do dia.

\section{Faixa 40}

DVD 02 / Faixa 40

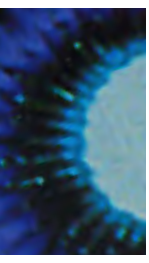

\section{A ORGANIZAÇÃODA RIA DRAMATÓRGICA}

DANÇANDO COM o sistemaprocesso, tecemos a TEIADRAMATÚR GICA que é a peça - experiência moldada em linguagem teatral. $O$ conceito teia dramatúrgica foi encarnado em palavras para que pudéssemos lidar com ele de maneira mais concreta, suá-lo em nossos ensaios ${ }^{62}$. Ele foi criado a partir da experiência e continua maturando-se a partir dela. Com o fim do mestrado e a escrita dessa dissertação, encerra-se mais um ciclo dessa pesquisaexperiência. No entanto, ela segue evoluindo e recriando-se em outras vidasexperiênciasobras.

Quando a vida começa a tecer em nós um projeto comum, a principal ação é escutar. 63

Conforme caminhamos e fomos encarnando a consciência sistêmica (e seguimos sempre encarnando em níveis mais profundos e mais expandidos), acredito que começamos a cocriar uma dramaturgia cênica que ressoa essa consciênciaatitudepensamentoposturamaneiradeexistir. Assim, a peça começou a ganhar um CORPO SiSTÊMICO, um CORPO CONECTIVO, um CORPO VIBRÁTIL, em que os sentidos e semsentidos se constroem nas relaçóes dos elementos que a compóem, em que nenhum dos elementos é mais fundamental que o outro, visto que os sentidos e semsentidos criam-se e recriam-se no E S P A Ç O E N T R E eles.

\section{A ORGANIZAÇÃO DA DRAMATURGIA CÊNICA.}

T А T E A R traz-nos a experiência da PELE. Para chegar à organização final da dramaturgia cênica (passando por suas mortes e renascimentos), tivemos que sensibilizar e convocar a presença da pele e da escuta, fechando de tempos em tempos os olhos e toda a linearidade e racionalidade que esse sentido (maravilhoso em sua potência) nos solicita. A prática era acabar com a tirania do olhar. Deixar que todas as nossas possibilidades perceptivas vibrassem em cocriação, ativassem a sua capacidade conectiva de cocriação de sentidos e semsentidos. 


\section{aBRIMOs os OUviDOs da PELE.}

A SABEDORIA I N T U I T I VA, que se manifesta quando um grupo de pessoas se reúne para viver uma experiência, foi cultivada entre nós. Quando damos tempo e espaço para que essa qualidade de sabedoria se manifeste, trabalhamos em cocriação. gica somente surgirá quando

aliarmos ao nosso conbecimento racional uma intuição da natureza não linear de nosso meio ambiente. Tal sabedoria intuitiva é característica das culturas tradicionais, não letradas, especialmente as culturas dos indios americanos, em que a vida foi organizada em torno de uma consciência altamente refinada do meio ambiente. $\mathrm{Na}$ corrente principal de nossa cultura, por outro lado, foi negligenciado o cultivo da sabedoria intuitiva. (CAPRA, 1982, p. 31.)

\section{CADERNO DE RELATOS II}

\section{TJT52 - 04 de jultho de 2013. (Relato de Janaína Silva, 04 de julho de 2013)

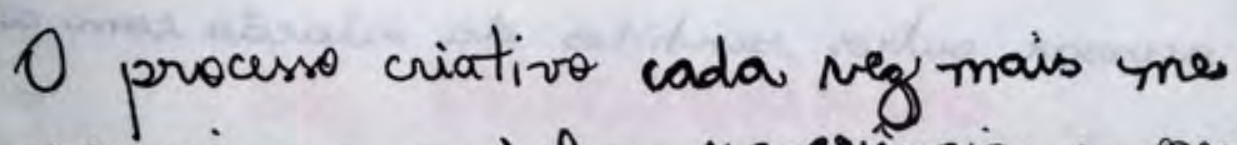 ajuda a organizar minha experiencia e a organizacaio da mintha exeperiência contribui para a organizaço en matenializaçáo das iderasedos

กับนทน

A palavraconceito COCRIAÇÃO encarnou em nosso sistemaprocesso simultaneamente à teia dramatúrgica e pareceu-nos bastante coerente, pois, ao usar a palavra COCRIAÇÃO, botamos em foco a criação que nasce da relação. A modelagem dessa palavraconceito, e o seu constante ressoar em nosso espaçotempo de cocriação, fez com que experimentássemos outra qualidade de relação entre nósł mais cooperativa, mais receptiva, mais passiva, mais pacífica, mais WִN. A palavraconceito cocriação, que para essa pesquisaexperiência encarna a consciência sistêmica, foi incorporada e ganhou corpo, conforme o sistemaprocesso encarnava durante a trajetória percorrida.

No contexto do nosso sistemaprocesso, a cocriação não ficou restrita às relações entre as artistascocriadoras que compunham o grupo. Realizamos vários encontros com outros artistas, amigos, conhecidos e desconhecidos para, através da RELAÇÃO CoM O OutrO, dar passos. Mesmo os encontros para colheita de narrativas (lá nos primeiros movimentos com a família) já eram encontros de cocriação.

\section{O DESEJO DE OUVIR A vOZ DO OUTRO JÁ ERA UM DESEJO DE COCRIAÇÃO.}

Realizamos encontros com cocriadores, para compartilhar aquilo que estávamos modelando em peça teatral, no CEPECA; convidamos amigos, artistas ou não (pessoas que trabalham em diferentes áreas) para assistir a alguns ensaios; criamos encontros como o da experiência com a argila ${ }^{64}$; realizamos alguns encontros específicos com outros artistas para trabalhar com a voz ou com os nossos tambores. Outros encontros ainda foram para conversar sobre a temática da peça e colher narrativas, para ouvir a voz do outro - que chamamos de Círculo de Falas. 
Fizemos nossa primeura Amostiagem / Compartilhar do processe:

$3 \times$ durante uma semana,

dia $19 / 03$ - Maitề Uuias - Éder

dia $21 / 03$ - Cepeca

dia $22 / 03$ - Andrea Drige

Todos as incentros com pessoas de $\neq$ mundos e refếncias foram muite precie ses. Revelou-nos o que apresintamos de força, de essincia no trabalho, to que necessitamos trabalhar mais. No gial, as pesseas se involveram i ficaram curvosas em conticer o trabalho, em salur o que vai resultar dali.

Comentárias que brotaram nos encontros:

- Presengas fortes. Magnetismo Sintonia, afinaçäo entre a gente. Encontro de diferentes.

- Os uncercícios revelam a experiencia, o trabalho que estamas reali zando. T) trabalho demonstra confiança maturidade naquile que propuse mos.

- Necessidade de (ser for uma excolha) desenvolver mais conflitos.

- Necessidade de trabahhar com nossa AERESSIVIDADE. Ganhar mais voz de base, abuir espaços, ter apojo da base.

- Andrea: abrir a escuta das costas, de trás da calrega, espaços YiN, lunaves, uscuros; abuir espaços de R1, uspaços YiN num primuire momento pode parecer contraditório, quando säo complementares.

¿Que encercícus criar para trabalhar com essas qualidades de energia?

- Tospace de feminino, de cérculo, mulheres navrando. 
O encontro com o outro, principalmente nestes primeiros movimentos do sistemaprocesso, era um espelho para nós. Víamo-nos através do outro. Sentíamos necessidade disso; afinal, nós duas (neste momento só estávamos Janaína e eu) estávamos completamente entregues e mergulhadas no sistemaprocesso, e o movimento de distanciamento, que também é imprescindível para dar passos, concretizava-se de maneira mais efetiva no encontro e através do outro.

\section{EU sou um outro VOC $\hat{A}^{65}$}

O desejo no encontro com o outro era o de VIBRAR E SENTIR RESSONÂNCIAS. Ao final de cada encontro, fazíamos o Círculo de Falas, aberto para as vozes que quisessem compartilhar as ressonâncias que vibravam em seu corpovoz. Não é um trabalho simples, visto que a maioria de nós tem tendência a emitir opiniões, falar do que gosta ou não gosta, falar das referências artísticas que lembra ao entrar em contato com determinada obra, em vez de falar sobre impressões, estados, sentidos, sensações, semsentidos que estão vibrando no corpovoz e no espaçotempo no momento presente. A nossa fala, que abria o Círculo de Falas, convidada à ressonância, procurava conduzir-nos para essa vibração. Estamos ainda experimentando e descobrindo o que dizer e como dizer para irmos todos para o E S P A Ç O DA RESSONÂNCIA, para esse espaço de escuta e cocriação.

Algumas vezes (quando havia tempo!), logo após compartilharmos o material artístico, antes de abrirmos o espaçotempo para as vozes, já acomodados em círculo, propúnhamos o exercício da Escrita em Fluxo ${ }^{66}$ para os presentes, para estimular um compartilhar de ressonâncias que trouxesse o CORPO EM VIBRAÇÃO. Nós fazíamos junto o exercício e, ao final, pedíamos para ficar com as folhas de cada um.

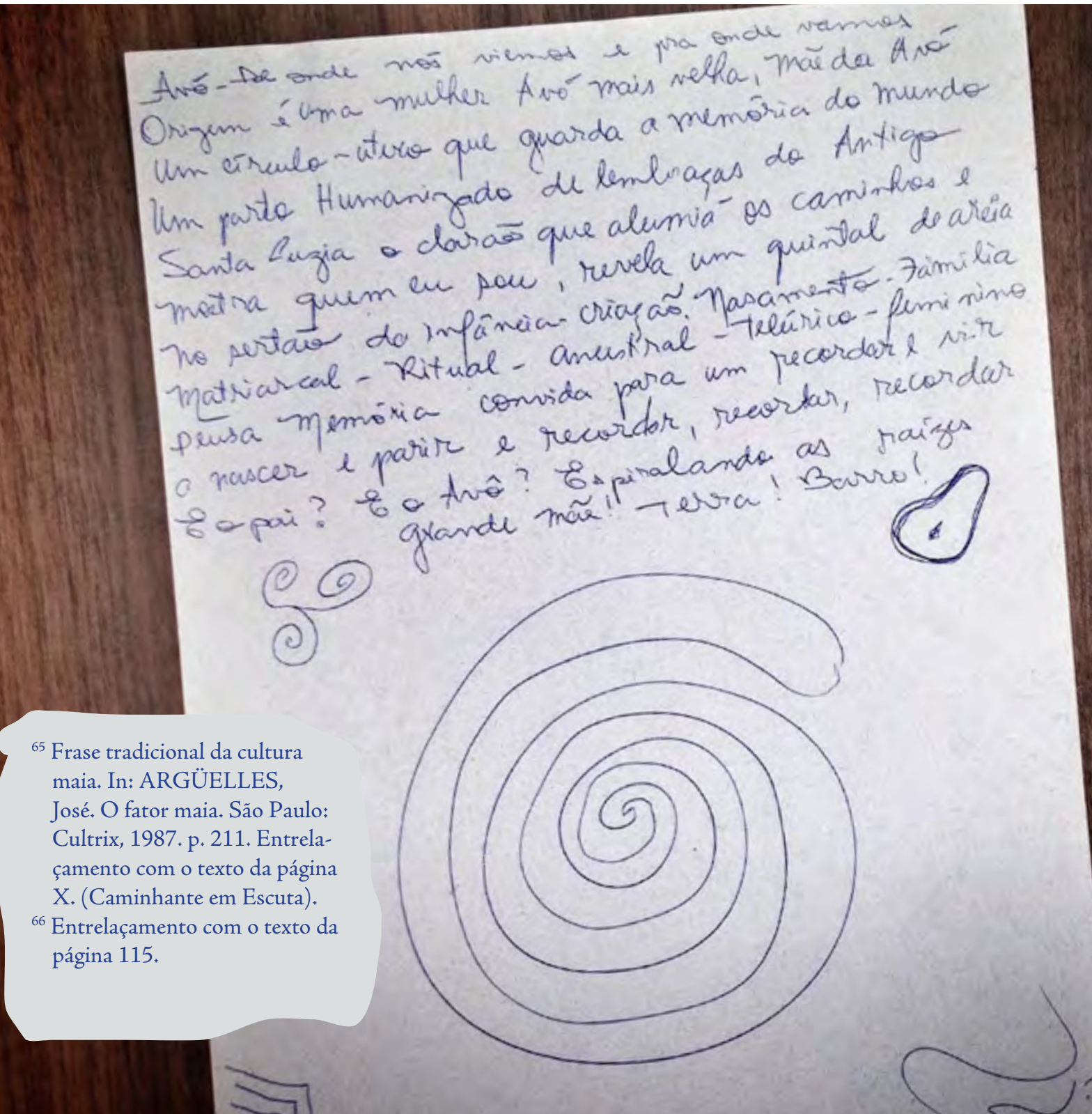



sujeito da experiência

é um sujeito "ex-posto". Do

ponto de vista da experiência, o

importante não é nem a posição (nossa

maneira de pormos), nem a "o-posição" (nossa

maneira de opormos), nem a "imposição" (nossa

maneira de impormos), nem a "proposição" (nossa

maneira de propormos), mas a "exposição", nossa

maneira de "ex-pormos", com tudo o que isso tem

de vulnerabilidade e de risco. Por isso é incapaz de

experiência aquele que se põe, ou se opõe, ou se impóe,

ou se propõe, mas não se "ex-póe". É incapaz de

experiência aquele a quem nada the passa, a quem

nada the acontece, a quem nada the sucede, a

quem nada o toca, nada the chega, nada o

afeta, a quem nada o ameaça, a quem

nada ocorre.' (BONDÍA, 2002,

p. 24-25.)

Mantivemos uma prática constante de COMPARTILHAR COM COCRIADORES - de EX-POSIÇÃO -, às vezes convidávamos as mesmas pessoas para acompanhar os passos do sistemaprocesso, junto com outras pessoas que nadam conheciam do que estávamos fazendo. Tivemos, com a prática e constância desses encontros, que tomar alguns cuidados.

proussa

\section{CADERNO DE RELATOS IV}

(Relato de Renata Vendramin, novembro de 2013)

Reflexöes e Assentamentos a partix dos ensaios de 11/11 sa $15 / 11$ :

Comor lidar com a presença dos cocriadores que vem ver o trabalho de vez em quando? I mavovia para a gente 'mostrar' cenas ou trechos de cenas e näo poura estar junto durante a feitura da cena, lidando com as cuises do processo criativo?

Sinto que temos que estar muito atentos para nöo buscar na fala dos corriadous a duuçäo que näo excisted. A ausência de uma direça to uma especificidade e uma escella para este trabalho. Acredito que tbrn temos que pensar em $\neq$ s nivis de cocriaçäo, o Alencar e a Gabiul estäo presentes no dia a dia, tendo/criando experiências com a gente, les estáo dentre, imerse no processo criative, que ó \& do públice que rriá $1 \times$ on de outro parcuiro cocriador que vem de vez em qdo. 
Janaína por muitas vezes disse sentir falta de ter uma pessoa que ocupasse a função de diretor e outra de dramaturgo, ou uma só que realizasse as duas funçóes. Pessoa(s) que nos ajudasse(m) a organizar o nosso sistemaprocesso. Sempre que ela trazia essa fala, quase sempre angustiada, eu ponderava que a organização era uma função nossa dentro da prática de cocriação que vivíamos e também do próprio sistemaprocesso em sua capacidade de autogestão. Nós tentamos, no início, convidar amigos artistas que pudessem dirigir ou contribuir com a dramaturgia da peça, o que seria possível também dentro do processo de cocriação, mas a parceria não aconteceu no começo e, depois que os movimentos começaram a se encorpar, não parecia orgânico tentar integrar alguém a essa função. Ou seja, teríamos que fazer da especificidade de não ter uma pessoa que cumpra a função de diretor uma escolha do trabalho, que a meu ver era bastante coerente para encarnar uma experiência de cocriação. Experiência que inclusive já havíamos vivido na criação dos dois trabalhos anteriores do grupo, em que não tínhamos uma pessoa atuando na figura de diretor.

FOLHA AVULSA DE RELATO

3658

(Relato de Janaína Silva, 05 de setembro de 2013)

enco de netembro de das nil e trize

Iá difíil tá difúil tá difícil

por onde pra que como qual

$\theta$ caminho? falta tanto falta

quanto? fatta minto falta

falta folta falta fala

fala fala fala solta mexce

olha interage respira a coura

e deirea limpo o espraco pra

contimuar a andar e anda anda

anda e oune som da nova

preserva disineminel tão disposta

trá aluerta excenta selembra reconecta

e vai vai vai e danca e lembra e

fala e mexe e ralina que se vorê

anda de onilus de arraío an de

Carro a Lua vai funto? falia que

quando ul una crianca póde deircar

nó que quando du preser en var

matar a tirov que comer sua mäe

da llia a uhumua nompéde chupeta

enorme $\theta$ elifante mais cinza de todos

os unzas com foce e foro e fora e

foca que a cana bai i ganka forma e

se ereprande e ganha sentido e gera sentido tá fluindo ta fluinds tá flundo ron onde

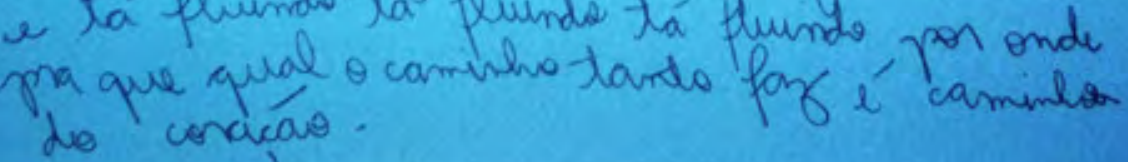


No entanto, mesmo conversando bastante sobre isso, era preciso estar muito atentas para, no encontro com o outro (no compartilhar com cocriadores), não buscar pela figura de um diretor, por uma fala que nos desse o "norte salvador"; afinal, não estávamos perdidas, mendigando respostas para algo que nós escolhemos e desejávamos cocriar; a direção era, sim, por escolha (consciente ou dada pelo contexto, pouco importa), compartilhada. Essa era a qualidade de experiência que encarnávamos.

\section{CADERNO DE RELATOS IV}

(Relato de Renata Vendramin, novembro de 2013)

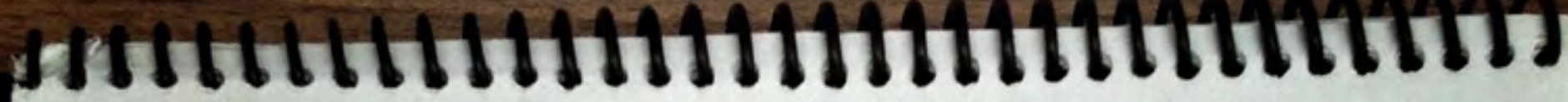

e cocriagäo é um encurcício fino de relagão;

de saber ouvire \& falar;

de receber e recusar;

de equilibrar energias YiN e YANE.

Tăo quexmininos comparti thar com o outro o nosse procusso cruativo para ter: APROVAÇÃO

\section{RESPOSTA}

OPINIÃo

Eu lusce Ressionáncias, ir além do gosto es ponto de vista pessoal, perceber o que surge na relagáo do outro com o ispetáculo. Me interessa sentir a resperacäo de outre durante e depois da peça, seu alkar, o tem de vioz com que comenta... par onde ile transitou

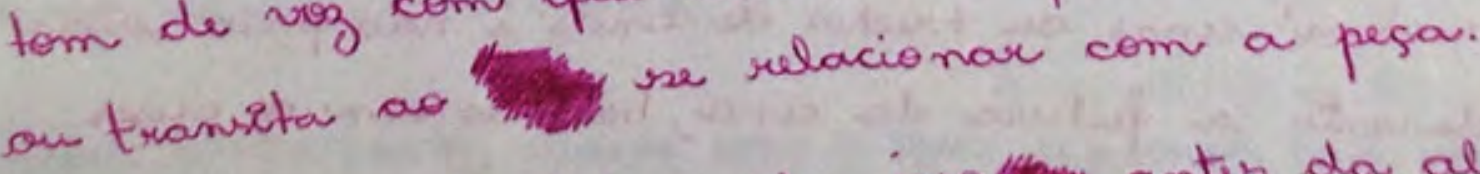

Acho interessante falar sobve isso theng antes da abertuca de processer parar que nossas presencas, falas e iscutas ovim este espage de RESSONANCIAS. ¿Por que vecê ante necessidade de compartilhar com 
A intenção do encontro com o outro era de sentir ressonâncias,

\section{COCRIAR UM E S P A Ç O T E M P O DE RISSONANATAS.}

E, a partir dessas ressonâncias, fazer escolhas dos próximos passos, assentando-as, deixando-as vibrar em nossos corposvozes. Também o ASSENTAMENTO DO ENCONTRO COM O OUTRO precisava ser feito pelo nosso corpo vibrátil, não somente pelo nosso corpo racional, que está acostumado a atuar como o tirano do olhar, ávido por linearidades, respostas, lógicas e conclusões. Do contrário, era fácil acabar com propostas ainda em fase de germinação (necessitando serem cuidadas para crescer), porque o outro não entendia, não conseguia enxergar sentido ou simplesmente porque não era do seu gosto estético.

Quando integramos mais gente no sistemaprocesso (produtora, figurinista, iluminador, cenógrafa), acredito que algumas dificuldades se intensificaram. O desejo era que essas pessoas estivessem desde o começo conosco, encarnando o sistemaprocesso, lidando com seu caos e todas as suas crises. Não foi possível, como já relatei. E, quando elas se integraram ao sistemaprocesso, também não tinham disponibilidade para estar sempre, então vinham às vezes acompanhar a evolução do trabalho. Não vinham com tanta frequência a ponto de integrar-seentregarsemisturar-se, e vinham com a frequência necessária para começar a intervir como um olhar de fora, que está presente constantemente, assumindo quase a função de uma direção. Neste ponto, por muitas vezes, quem se angustiou fui eu. Trazia também a reflexão para o grupo e principalmente para Janaina e para mim mesma.

\section{CADERNO DE RELATOS IV}

respersto (Relato de Renata Vendramin, novembro de 2013)

mos o

Um procosso de COCRIAÇẢo pussupär prerença, envoluimento, untuga dos COCRIADCRES para que nöo acale

sende lidero por um ou pouces. I liderança continua excistindor, ela é compartilhada, ruvezada, a proposta é que todas tentram a opontunidade de lideraue! I) treine da Escuta nos ensina a reconfecer quem está com a lideranga, com a FORÇA CRIATivA a cada memento, "ila pode ser compartihad a thom, 1,2, 3 lideracem. Esse revezamento nos dá mais relarcamento, tranquili dade, $\vec{n}$ depende só de mim. Eu sou mais ür que tem muite valer e que ustá tendo uma oportunidade de apeendizado colativo.

As voges se relacionam e as contradiçois $\tilde{x} \tilde{s}$ silenciadas! 
Quando Alencar, o primeiro artistacocriador, para além de mim e Janaína, integrou-se ao sistemaprocesso, demo-nos o espaço e o tempo necessários para ele chegar e assentar-se. Um espaçotempo para afinarmos o RITMO DA NOSSA RESPIRAÇÃO. Sem que nenhum de nós precisasse impor um ritmo, harmonizamos nossas presenças e nossa respiração com a respiração do sistemaprocesso. Com as demais foi diferente, não nos demos espaço e tempo. ${ }^{67}$ Apesar disso, cocriamos muita coisa juntas, que deu certo; no entanto, começamos, neste momento, a perder muito das qualidades $\mathbb{Z} \mathbb{N}$ que pacientemente vínhamos encarnando... A peça começou a se expandir em ideias de cenários mais complexos, mais grandiosos, os figurinos só aumentavam, as músicas ganharam uma grandiloquência...

\title{
wam YANG YANG YANG YANG
}

... afastamo-nos de nossa simplicidade e afetividade genuínas.

\author{
PERDEMOS O SENSO DOS NOSSOS LIMITES. \\ UM LIMITE EM QUE PODÍAMOS R E S P I R A R, DAR-NOS TEMPO E E S P A ÇO. \\ ATROPELMOS RPPRMEMUS, ESTRANGULAMOSO TEMPO E O E S P A Ç O. \\ PRENDEMOSA R E S P I R A Ç Ã O.
}

Acredito que nos envolvemos em um movimento de expansão maior do que daríamos conta naquele momento, preservando o espaçotempo da experiência.

Entrelaçamento com o texto da página 79.

${ }^{68}$ Entrelaçamento com o texto da página 80. 


\section{CADERNO DE RELATOS III \\ (Relato de Renata Vendramin, 07 de março de 2013)}

da cena.

Reconhecimento neste processo de cocriaçäo de que as necessidades brotam da ixperiencia en conjunto 2 as respostas term. Giamos is imantamos um ambiente de cocriacäo im que recontecumos im quem a forga criativa se manifesta a cada instante, pode ser que seja nas 2 ao mesmo tempo, pode ser que im 1, e cada a força creativa se apresenta, a gente reconfieca

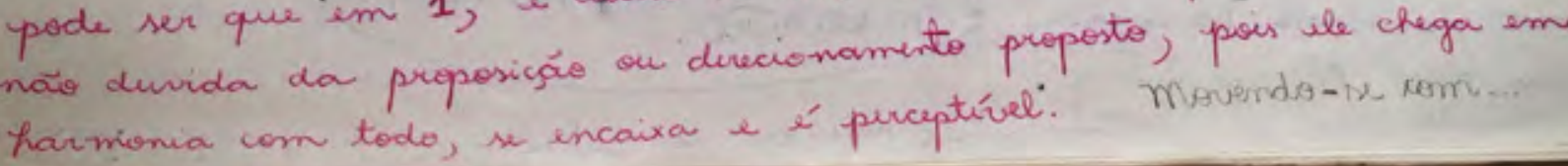

Neste relato acima, dos inícios da pesquisaexperiência, falo sobre a SABEDORIA I N T U I T I V A do sistemaprocesso, essa capacidade que todos os sistemas têm de autogerir-se, autorregular-se, que é bastante relevante para a nossa reflexão. No entanto, utilizo a palavra encaixa na última frase do relato que, considero agora, não ser a escolha mais coerente, por trazer a ideia de partes que se juntam. Assim como esse, tantos outros relatos trazem palavras como encaixar, engrenagem, peças... que nos conduzem à metáfora do mundo como máquina, e não como rede.

A METÁFORA GUIA DO NOSSO SiSTeMaPROCESSO É OMUNDO COMO UMA TEA

\section{Tow \\ $06 / 02 / 13$}

CADERNO DE RELATOS II

(Relato de Janaína Silva, 06 de fevereiro de 2013)

2015

A Próxima História (2)

Estar em procusso de criacão de un trabalko täo urgente, täo "querente" de sir dito, comprartilhado, vivido...é assim como saber, em algum lugar do corpo, do vorlacão, a sensação de tê-lo conclúdo nas e ao menmo tempo me ver diante de um ponto de caminho em que é porsivel ver mintas trilhas, virlas, caminhos, becos, túneis, portais, pecas, olsetos, de muitas cores, tons, toxturas... e uaiz shäo as pecas da nona historia-engrenagem? e qual una a cor dena e daquela historia funtas, amalgamadas? Se apesenta a necessidade da escollea, do refinamento eda memorizacão des históitas, das memórias de cada uma. Assi 
Nos dois relatos acima, vemos a encarnação de uma consciência sistêmica em desenvolvimento (e ainda seguimos em desenvolvimento). Esbarramos e lidamos com as metáforas e os padróes que alimentam, criam e recriam nosso imaginário, nossa maneira de existir no mundo. A desconstrução de algumas metáforas que nos compõem é um trabalho bastante sutil e profundo.

SE MUDAR A METÁFora, MUdO O PADR̃̃o?

\section{CADERNO DE RELATOS IV}

(Relato de Renata Vendramin, 04 de dezembro de 2013)

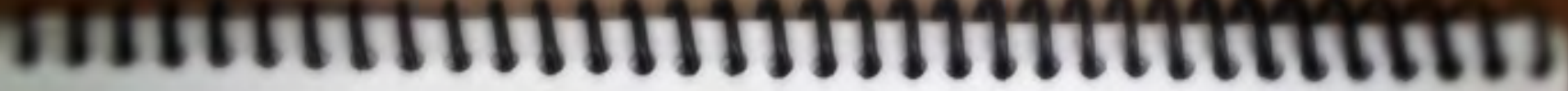

fana mitas vezes busca construie una dramaturgia que se 'resolva' na palavra, e as propostas de dramaturgia que š propostas $p /$ se construir na cena: nos corpos em relação, nos elementos un relaçäo são taxadas como 'frágeis. rapestas práticas que ela dás, p.324

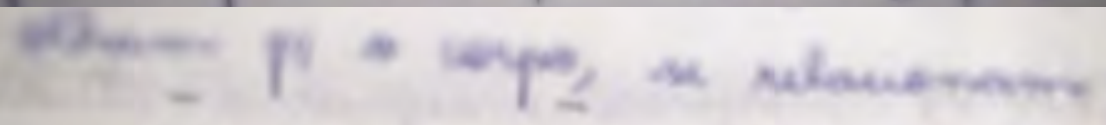

Reflexäo: As vezas a gente acha que está fazendo/ propondo mudangas radicais qdo na verdade estames dando un 'juitinho' para dixar as casias da maneiva como conhecemos e nos agrada. 
A devoração de Capra, Fabião, Brook e tantas outras vozespensamentos que ressoaram em nosso espaçotempo de cocriação nos ajudaram a caminhar, lidando com as questóesdificuldadesdesafios que se apresentavam.

\section{CADERNO DE RELATOS IV}

(Relato de Renata Vendramin, 06 de novembro de 2013)

Gidado para näo cair no padräo explicativo, de causatidade, como se cada célula tenha que ser explicativa, se concluir em si mesma.

Pors a que buscamos säo es sentidos criados has relacgós entre elas. SilÉncios. Para os

Cade os SiLENCIOS? As células de SiLENCIO? Tem alguma céluba só de Música? Oepois CHERA, antes passagem da Figura? Lancax

Eram recorrentes questóes como essas aparecerem. Elas retornavam ciclicamente. Era preciso respirar e prestar atenção a nossos padrões inconscientes, que buscavam e geravam linearidade e sentidos lógicos, que favoreciam a palavra e a fala em detrimento dos movimentos corpovoz, da música, dos sons, ruídos, gestos, da relação entre eles, para a cocriação de sentidos e semsentidos.

No dia 27 de setembro de 2013, chegamos, Janaína e eu, pensando e rascunhando, a partir de tudo que já havíamos cocriado e estávamos cocriando (e havia MUITA coisa sendo cocriada simultaneamente), a uma primeira proposta de organização da dramaturgia cênica, que, com muitas modificações depois, originaria a peça apresentada na abertura de processo de dezembro 2013.

ERA O
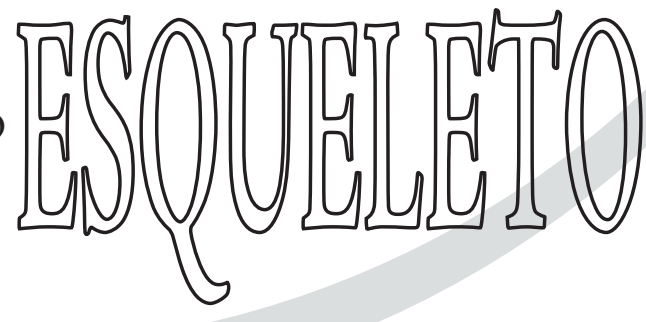

DA DRAMATURGIA. 
A FSTRUTURA

RELATO EM FOLHA A VULSA

(Relato de Janaína Silva, 27 de setembro de 2013)
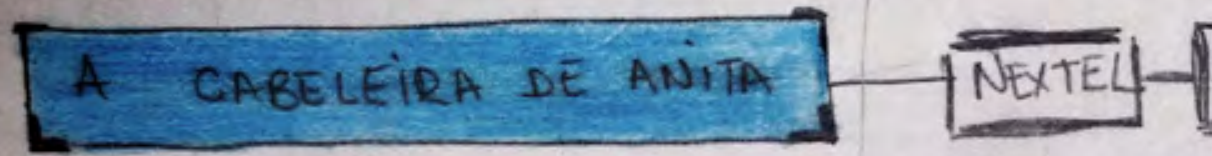

FANTÁSTICO

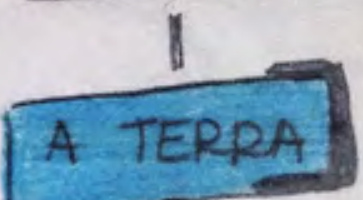

QUAL É SEU -

SONHO? "DEROIMENTO NAD TÓ FALANDO DISSO, MAS TÔ FALANDO DISSO

TRINCHEIRA

"NAO FAZ

acho que é a ligurom

SENTIDO"

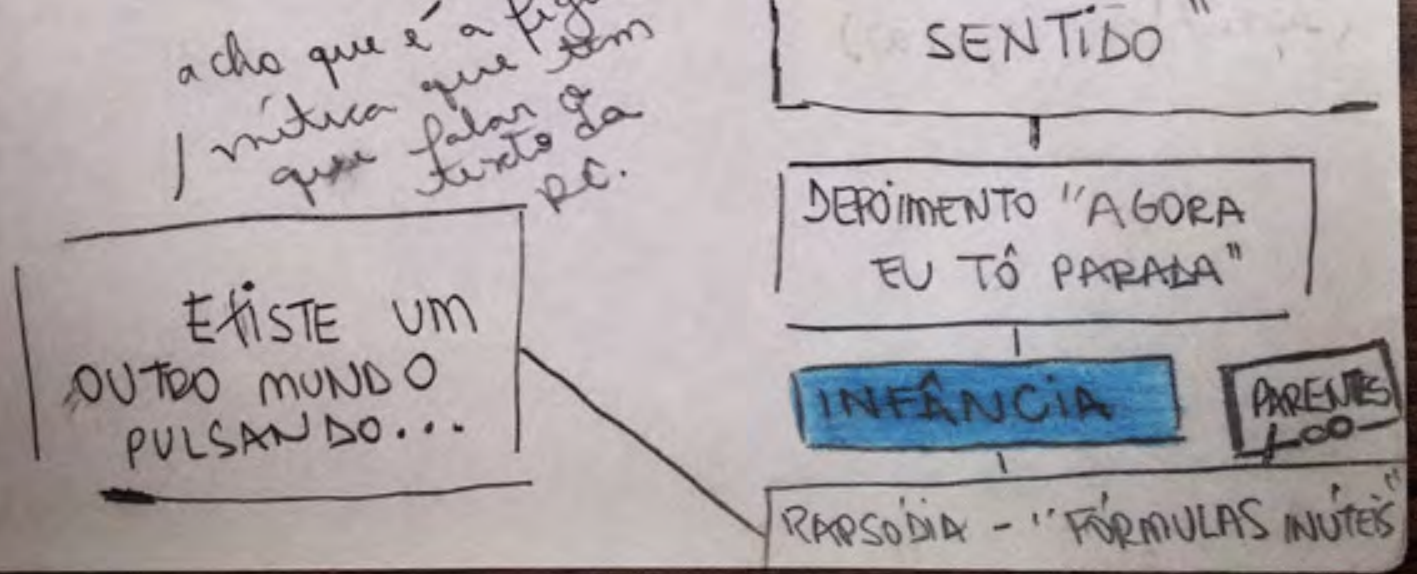

CADERNO DE RELATO III

(Relato de Renata Vendramin, 27 de setembro de 2013)

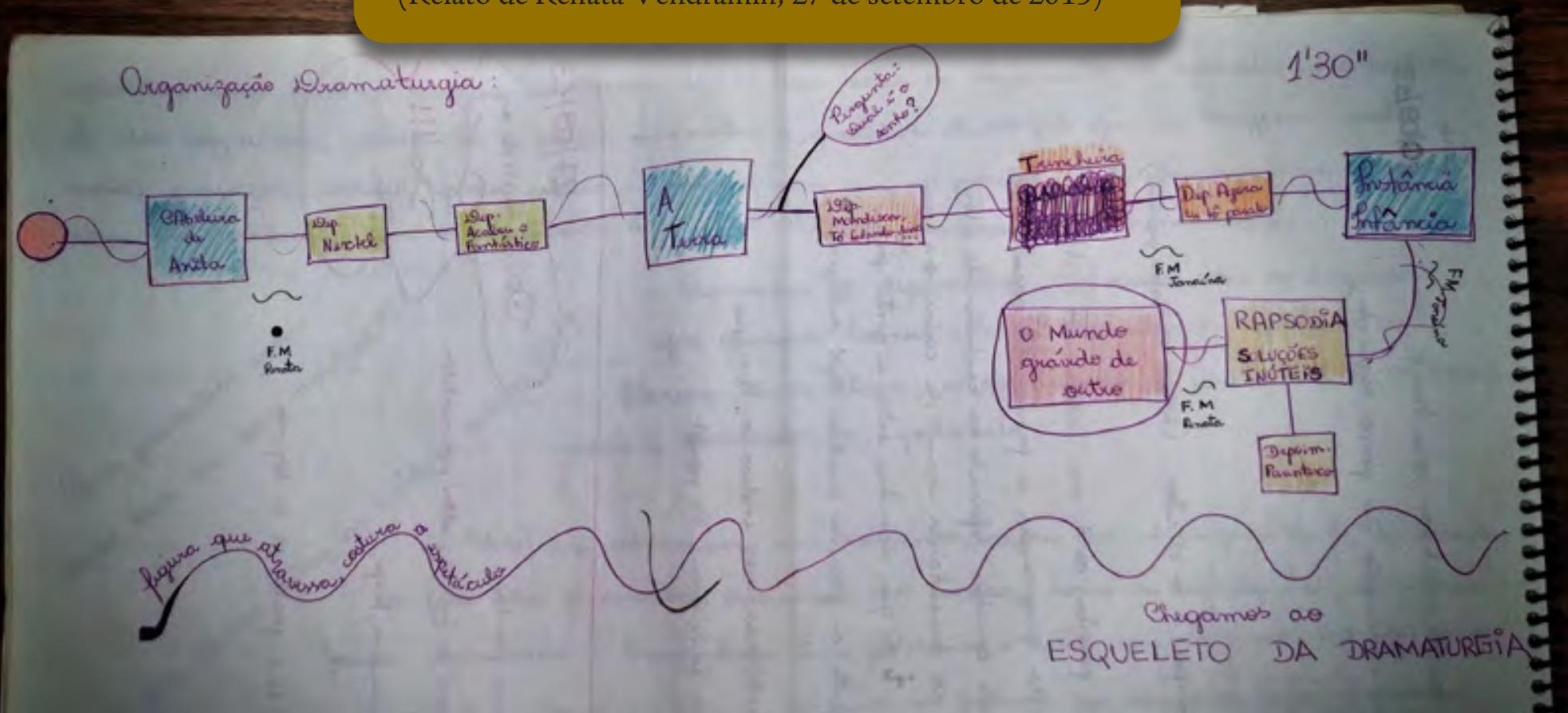


O corpo da peça ganhava uma estrutura de sustentação: a sua estrutura óssea. Ainda precisávamos suar essa proposta nos ensaios e, de fato, fizemos várias modificações. Contudo percebemos um caminho coerente que nasceu dessa primeira proposição óssea da dramaturgia cênica. O exercício de desenhar no papel esse esqueletocartografia da peça, a partir desse dia, foi feito e refeito inúmeras vezes, individual e coletivamente. Era uma prática que nos auxiliava a dar materialidade à peça. Enquanto realizávamos o desenho no papel, tínhamos espaço e tempo

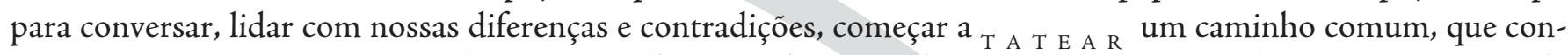
tinuava movente e poroso para abrir novas trilhas e atalhos quando preciso, mas que auxiliava na encarnação da peça - afinal, nos interessava sim a configuração da experiência em carne, em forma artística.
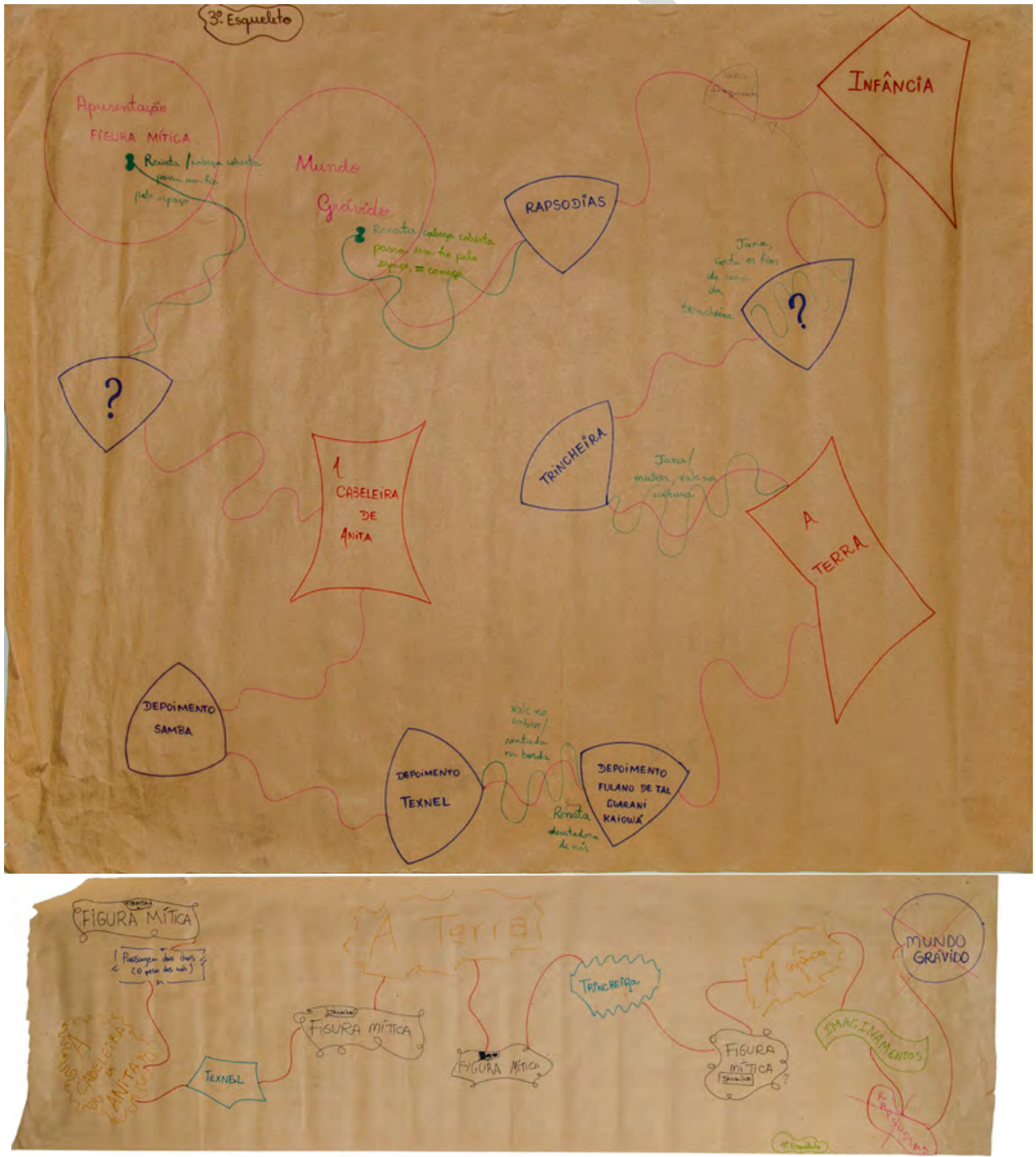
O fato de traçarmos a dramaturgia cênica em uma sequência (em uma ordem), como desenhamos nos relatos acima, por vezes trazia novamente ao espaçotempo de cocriação a ideia de uma linearidade e uma busca inconsciente (quase insana do olhar tirano!) de causalidade entre uma célula e outra. Eu constantemente nos relembrava de que os sentidos e semsentidos estavam sendo cocriados na relação entre as cenas, que justamente passamos a chamar de $\mathrm{C}^{E} \mathrm{~L}^{\mathrm{U}} \mathrm{L}^{\mathrm{A}} \mathrm{S}$ para trazer ao espaçotempo de cocriação a ideia de organismo, a percepção da peça como um CORPO, como um SISTEMA.

\section{AS C É $^{\mathrm{U}} \mathrm{L}^{\mathrm{A} S} \mathrm{~S}$ DO CORPOPEÇA, DO SiSTeMaPROCESSO.}

Para sair desse $\square$ LHAR QUADRAD $\square$, propus desenharmos as células usando círculos e outras figuras geométricas, ao invés de quadrados, e traçar a trajetória de maneira mais sinuosa, ao invés de uma linha reta. Mas ainda estávamos desenhando em um papel, lidando com uma superfície plana, bidimensional, era preciso IMLATENR a tridimensionalidade, a circularidade, a simultaneidade das células e sentidos e semsentidos que vibravam no momento em encarnávamos cada célula da peça. Afinal o corpopeça que estávamos cocriando, assim como os nossos, também é um

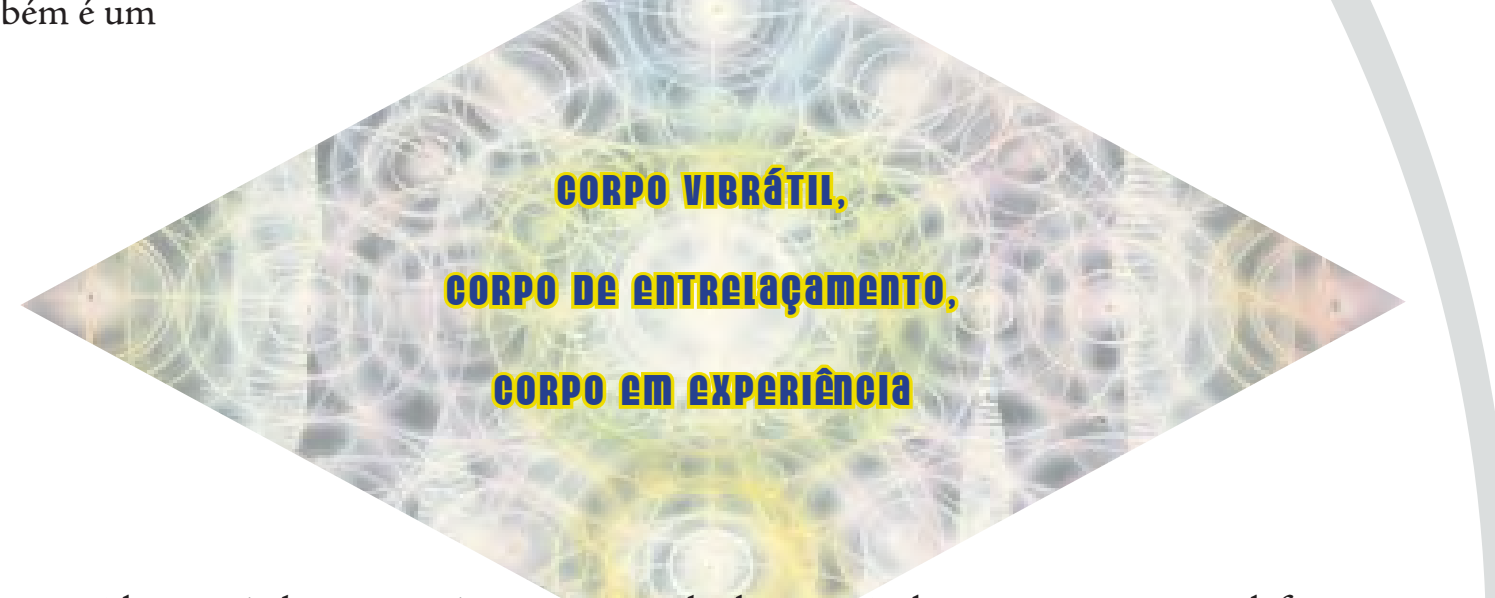

A peça, neste sentido, não é algo que está pronto e resolvido a partir do momento em que defino a concatenação de uma célula e outra, em que escolho qual será a primeira e a última. $\mathrm{O}$ trajeto da dramaturgia cênica desenhado é um caminho coerente a ser percorrido para criar e recriar sentidos e semsentidos, relacionados às perguntas e à temática que estamos tateando em nosso sistemaprocesso. E todas as pessoas que cocriam e compartilham a experiência teatral, incluindo o público, integram o movimento de cocriação dessa experiência.

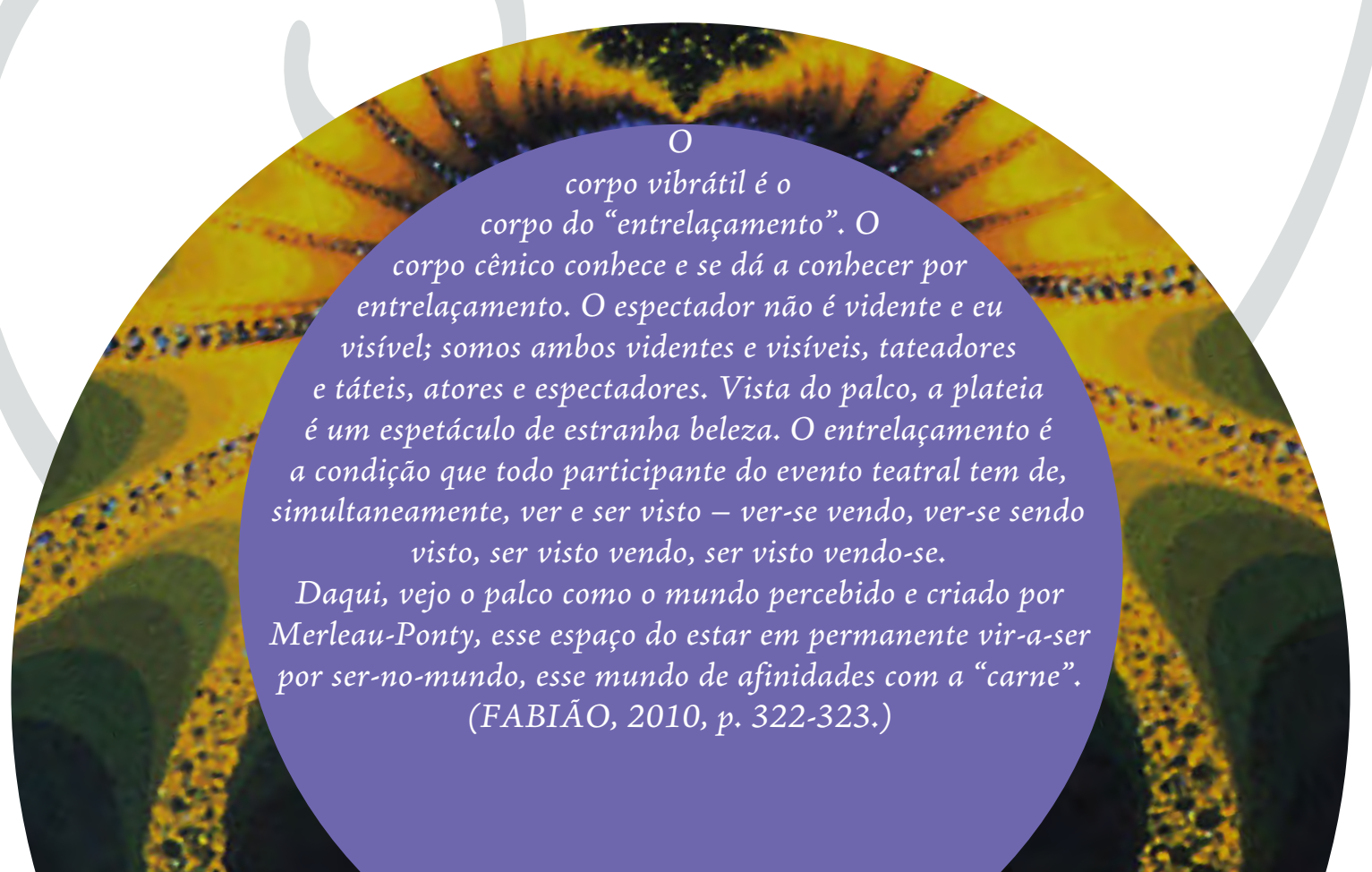


Um corpo está em constante movimento, mesmo que parado. Se para de movimentar-se, se para de pulsar, se para de respirar, morre. O corpopeça, cocriado neste contexto sistêmico, tem o mesmo movimentofluxo. Definir qual será a trajetória percorrida durante a encarnação da dramaturgia cênica não significa que deixaremos de respirar e seguir em movimento de cocriação. Temos que suportar viver a peça respirando, deixando os fios da teia (capazes de conexóes significativas), desobstruídos, para que a energia vital da peça flua, com ritmo, pulse vida, crie e recrie sentidos e semsentidos.

Quando iniciamos o segundo ciclo do sistemaprocesso, tivemos a oportunidade de fazer diferente, de escolher outros caminhos que não nos fizessem cair no olhar tirano, na linearidade, na necessidade de resposta, na expansão desmedida que explode limites e prende a respiração - dos nossos corposvozes e do corpopeça.

\section{DEIXAMOS OCORPORESPOSTA E RETORNAMOS AO CORPOPERGUNTA.}

Quando nos coloquei a pergunta: ${ }^{69}$

\section{CADERNO DE RELATOS IV}

(Relato de Renata Vendramin, 04 de abril de 2014)
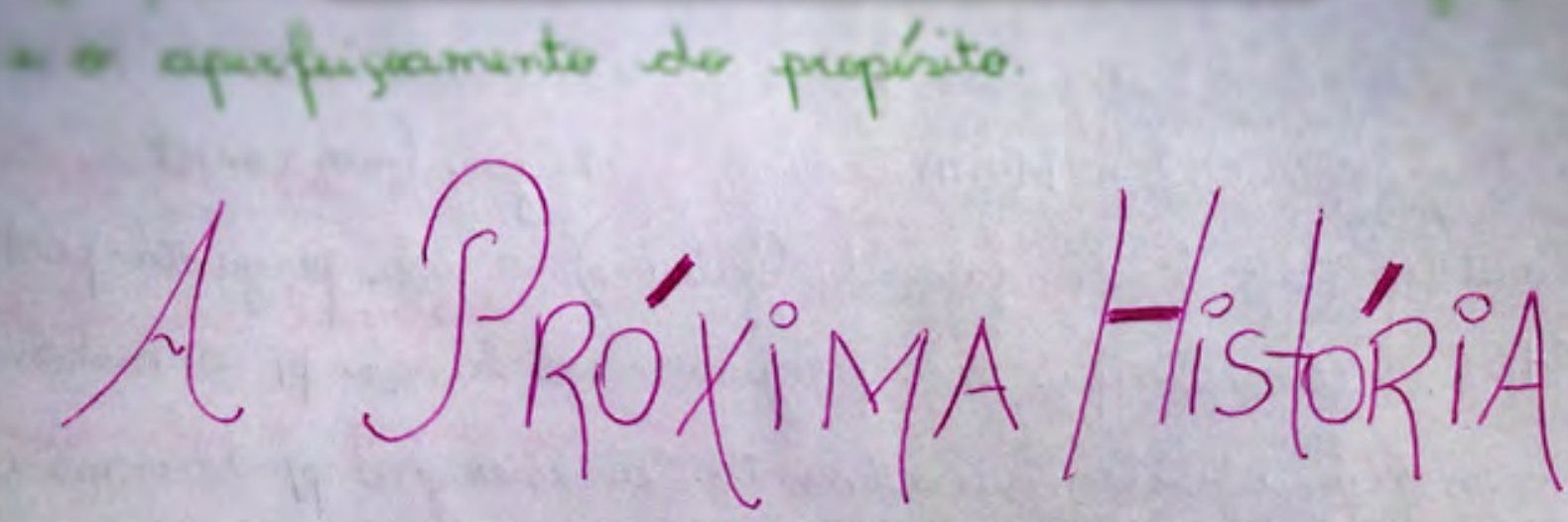

- (O que, de tudo que constrúmos até aqui, no espetáculo é esservial manter? Que diz respuito à essência è à forsa do espatáculo? Uma cena, uma pergunta, uma atmosfera, uma frase, uma palavica, um estado, um -movimente, uma música, um silêncie...

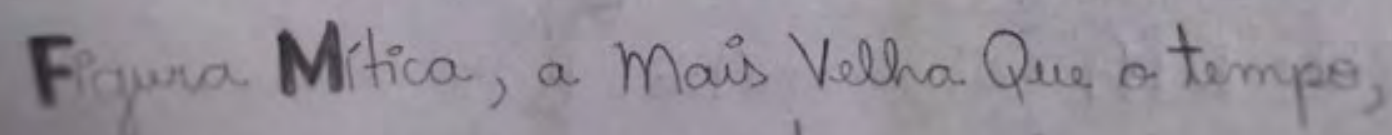

${ }^{69}$ Entrelaçamento com o texto da página 96 
Natural e coerentemente, no fluxo da minha escrita, a pergunta, que já estava encarnada no corpopeça na célula Imaginamentos, surgiu como possível direção para a dramaturgia cênica retornar ao seu caminho sistêmico, de entrelaçamento, de trânsito entre memóriaimaginaçãoeatualidade. Compartilhei com Alencar esse pensamentofluxocriativo e definimos que a peça seria a partir de agora possíveis respostas poéticas a essa pergunta. Então, habitamos, suportamos habitar o espaçotempo de cocriação, deixando ressoar as novas escolhas feitas, sem ter ideia ainda de que caminhos se abririam a partir daí.

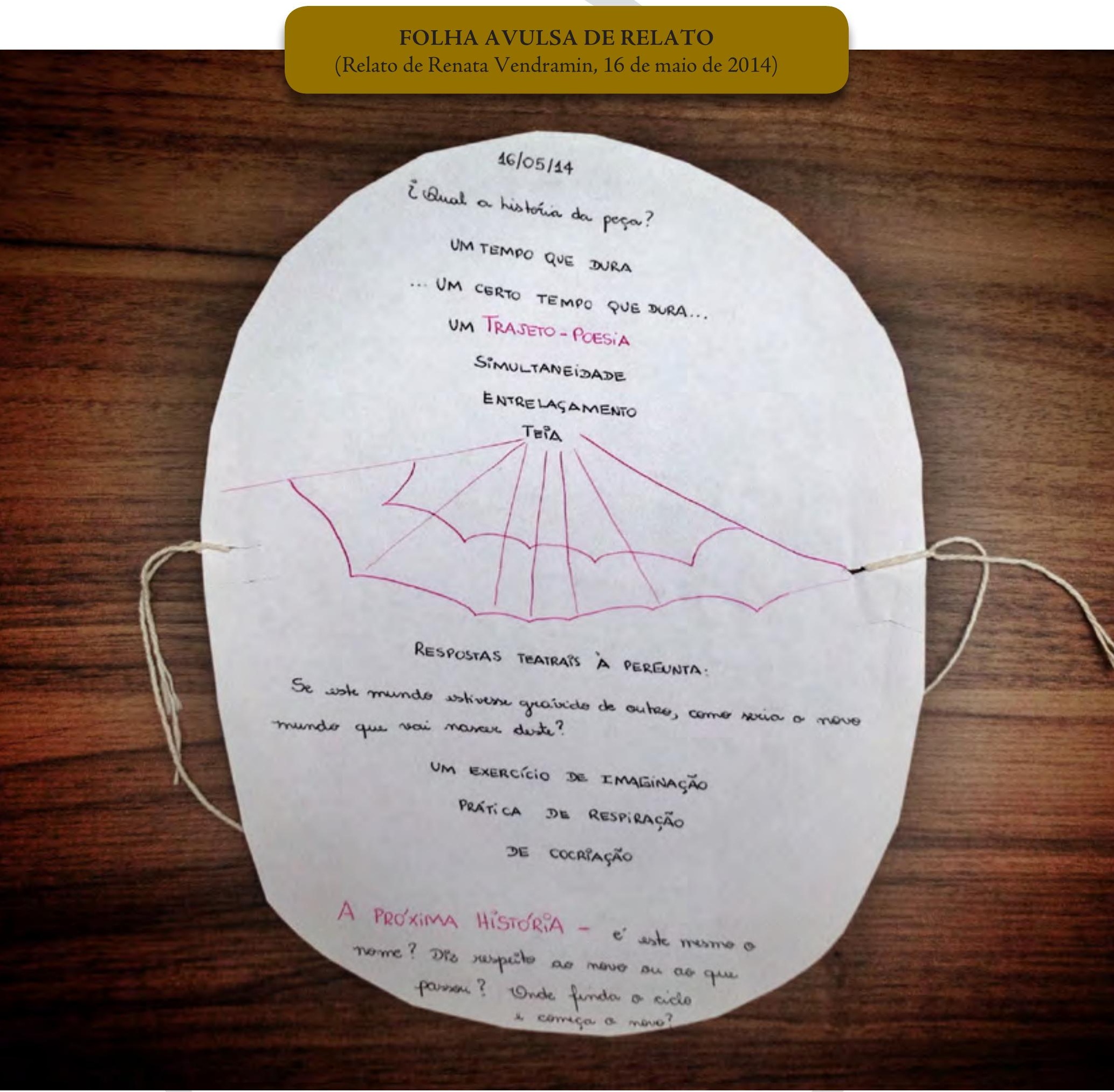

No fim deste relato, coloco um questionamento sobre o nome da peça. Assim como esse, tantos outros ressoavam em nosso espaçotempo de cocriação, quando reiniciamos o trabalho com a dramaturgia cênica que já existia e achamos coerente deixar na peça neste segundo ciclo. Integrando as questões, os medos, as dúvidas, as angústias, suávamos nos ensaios para cocriar novas relações com esse material, que dissessem respeito ao novo contexto que vivíamos, Alencar e eu. 
Foi então que, no final de maio de 2014, o esqueleto da dramaturgia cênica que deu origem à peça no segundo ciclo encarnou em FLUXOe R I T M O CR $\mathrm{R}_{\mathrm{T}} \mathrm{T}_{\mathrm{V}} \mathrm{O}_{\mathrm{S}^{70}}$, depois de um ensaio habitando o espaçotempo de cocriação sozinha em relação com o texto de $A$ Mais Velha que o Tempo. Anotei o que passava por mim sem pensar a respeito do que significava. Sem julgamentos, opiniões e dúvidas. Em escuta, tateando o que chegava.

\section{RELATO EM FOLHA A VULSA}

(Anotação de Renata Vendramin, 23 de maio de 2014)

(Sonoridades Figura Mútica)'íngua dos anyos' de funde.

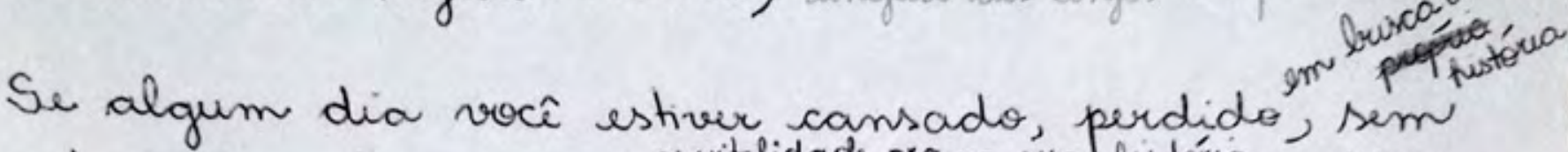
Ser alver cansado, perdido, sem vontade de imaginar, unitalidade pra la sua his tórig cante. 2Oizem que a mais velha que o tempo se aproxima do alento de qualquer criatura que cante

\section{DANCA $\rightarrow$ movimento AMVQT.}

to If se eu pudesse só por um segundo, rever os portoes do mundo que os avós criaram. Ito

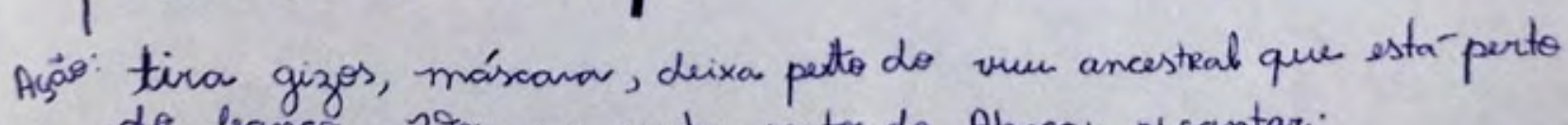
do banco. Wou me sentar perto do Alencar pi cantar:

- Ecos do mundo

- Senta imoutro banco disponivel na borda do cúculo pl "Solucaás Iruéteis." Embaixo deste banco deixau o caderno da infôncias

- Pego o caderro comego cena infáncia

- Prnaginamentos (dango?) - A próxima história 
A inspiração que encarnou a sequência de células da dramaturgia cênica, o seu SiSTeMa OBSSED, é uma ressonância da experiência que estava acontecendo desde o primeiro ciclo do sistemaprocesso. Todas as minhas possibilidades perceptivas, da mais racional a mais intuitiva, estavam integradas, habitando o espaçotempo de cocriação, respirando (inspirando e expirando o espaçotempo de cocriação) e suportando permanecer nele, ainda que as formas e os sentidos e semsentidos tivessem contornos muito sutis e frágeis.
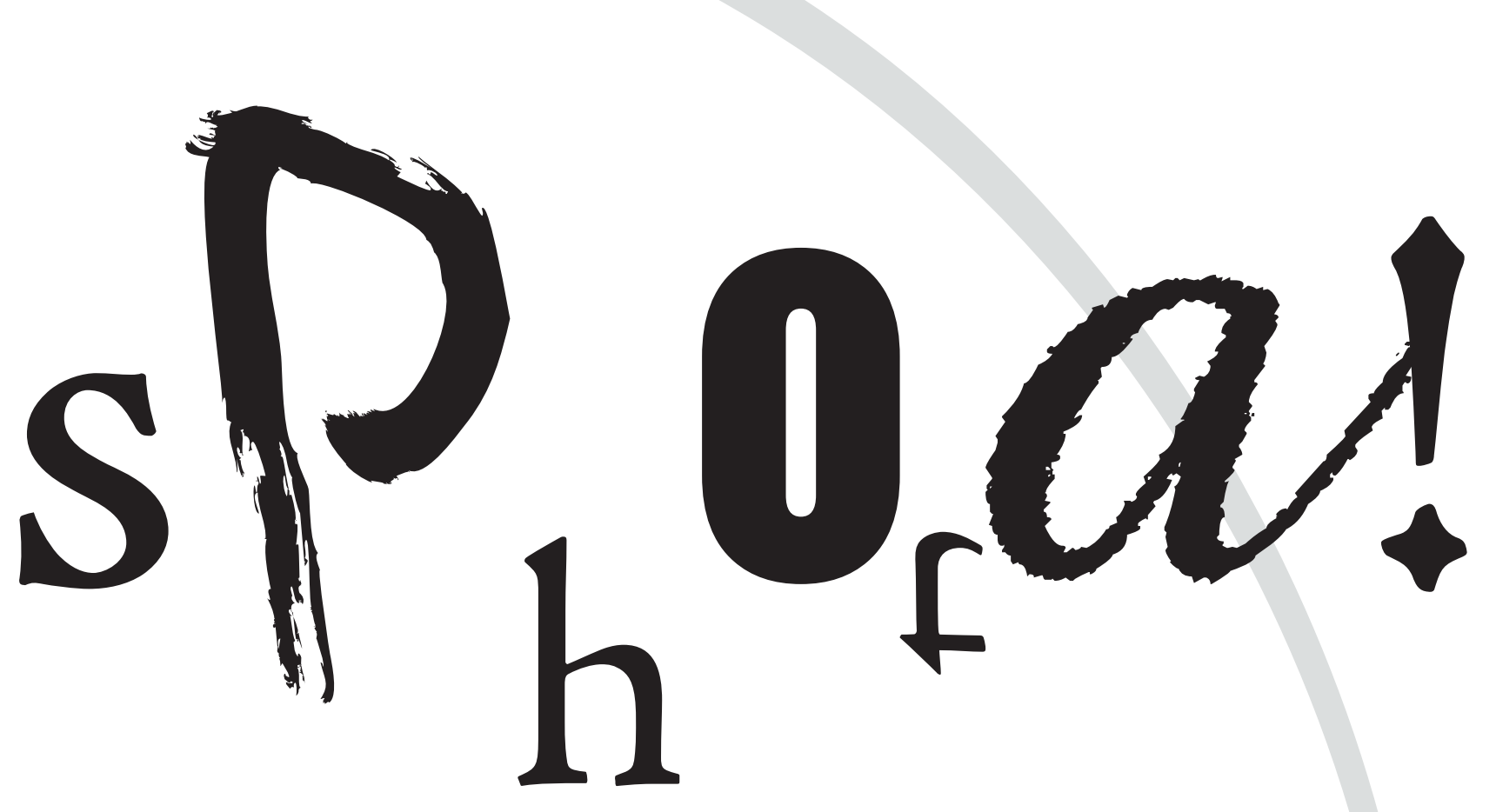

Suamos essa proposição óssea. Alencar a recebeu de corpo aberto. Transpiramos juntos a proposta, e, assim, o esqueleto mostrou-se coerente para sustentar todos os demais sistemas integrados a ele.

\section{O GORPOPERCUnTasISTêmIGOVIBRáTII}

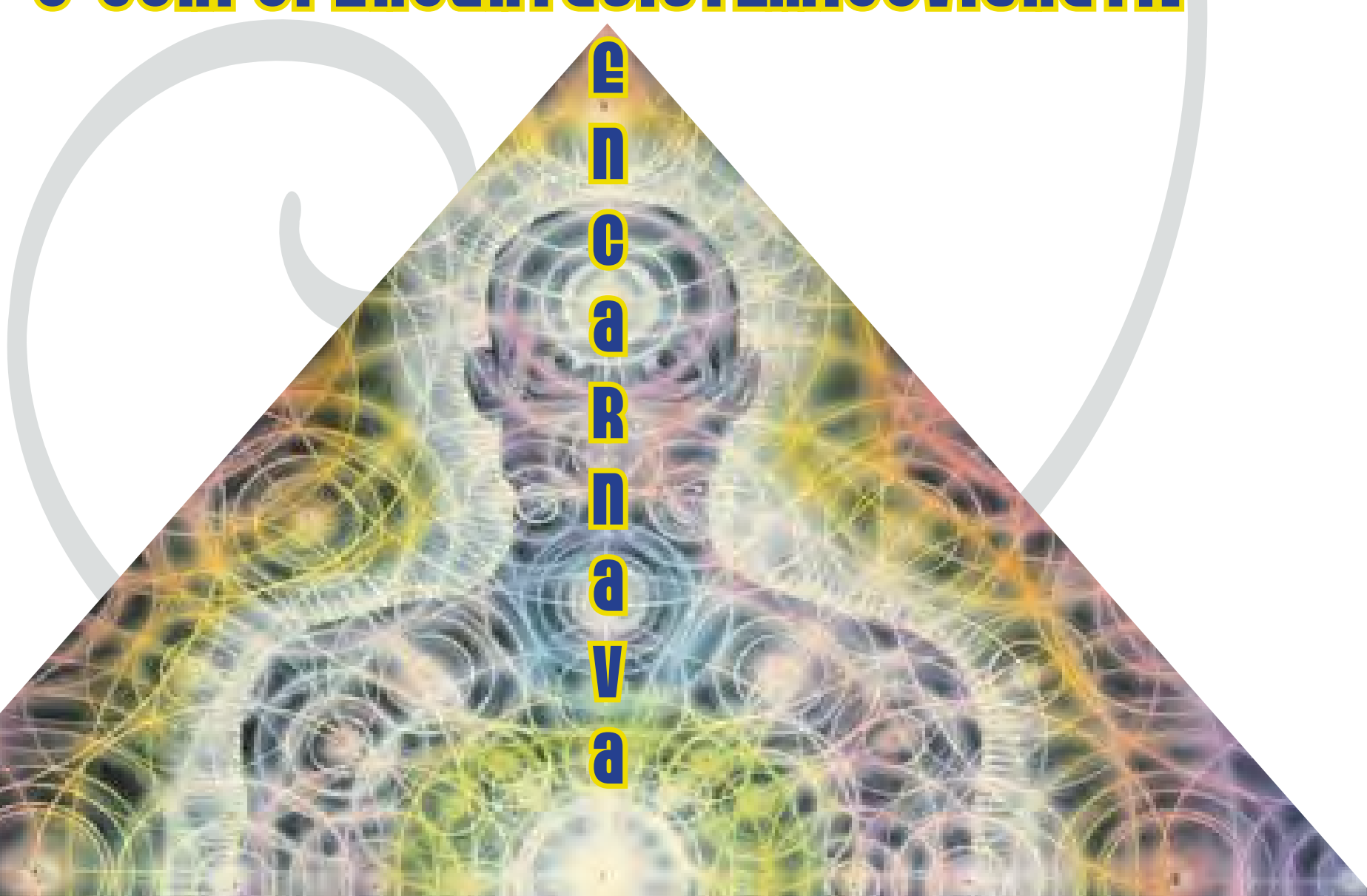




\section{PARTO}

$\mathrm{E}$

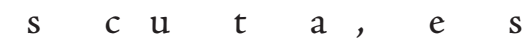

c u

$t$

$\mathrm{a}$

e

$\mathrm{S}$

$\mathrm{u}$

a + +

Faixa 41: A Feminina Voz do Cantor ${ }^{71}$

DVD 02 / Faixa 41

Aqui parto.

PARTO porque encerro o ciclo dessa pesquisaexperiência de mestrado e dessa experiência de leitura...

PARTO porque renasço outraS depois de toda a experiência vivida...

Pari a mim mesma: outra artistacriadora, uma artistapesquisadora, uma artistaeducadora (as duas últimas recém-paridas),

\section{DESDOBRAMENTOS DE UM ÚNICO SSP. VOZZSS QUE TÊM SUAS ESPECIFICIDADES E COMPLEMENTAM-SE EM SUA DIVERSIDADE.}

Aqui parto: inteira, íntegra, sistêmica.

Quantos nascimentos, mortes e renascimentos! Quantos partos durante a trajetória percorrida! E isso faz conectar-me à experiência da mulher ao dar à luz um ser humano: processo de encarnação, processo natural da vida, que acontece em fluxo e ritmo criativos. SPh $\mathrm{S}$ T $a$ ! Também faz me conectar ao ofício da parteira, não à médica do hospital precário e lotado ou superfaturado e espelhado, que marca a cesariana, liquidando o tempo e o espaço que a mãe e o bebê necessitam para viver suas experiências de PARTO; mas à guardiã do parto, em escuta, que não interfere no fluxo natural do acontecimento, que deixa a mulher parideira acessar a sua sabedoria intuitiva para viver a experiência, que é sua e da CRIAnça que encarna no planeta. A metáfora do parto faz também com que nos aproximemos da experiência do feminino: da força do feminino, da voz do feminino, da encarnação do feminino, que nos foram tão preciosas durante toda a caminhada.

Por muitas vezes trouxe a metáfora do parto durante essa narrativa poéticoinvestigativa, por acreditar que ela é uma metáfora justa para essa pesquisaexperiência de mestrado. No meu caso, artistacriadora que percorreu esses trajetos sinuosos na cocriação de uma peça teatral e dessa dissertação, sinto-me ao mesmo tempo a mulher parideira e a parteira. Todas as pessoas que foram o sistemaprocesso têm um pouco de mulher parideira e parteira. Estivemos a todo momento parindo - sentindo as dores e os êxtases da cocriação, e guardando, preservando o tempo e o espaço para que os nascimentos e as encarnaçóes ocorressem. Certamente, quanto mais tempo e espaço dedicamos ao sistemaprocesso, mais pudemos ter consciência e atuar com mais integridade nestas duas funções. 
Como uma jovem aprendiz de artistapesquisadora e artistaeducadora, que se cria e se recria em relação, a cada respiração em cada passo da caminhada, sinto-me um pouco parteira, um pouco curandeira, aquela pessoa que guarda um espaçotempo para que seres humanos possam manifestar sua força, sua criatividade, sua sensibilidade, sua inteligência, seus dons, sua beleza, sua integridade, confiando que todo $c$ a $m$ i $n$ b a $n$ t $e$ EM ESCUTA sabe qual o caminho a trilhar. Confiando no ser humano. Estou junto, perto, em cocriação, compartilhando possibilidades de caminhos, a experiência de trajetos percorridos, ajudando quando necessário, mas exercitando, acima de tudo, a escuta aberta e uma relação que menos FECHA, FORMA-

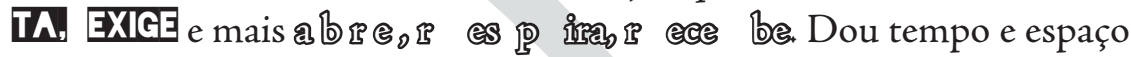
para a experiência, para que manifestem a sua vOZ PoétıCA. Para que alcem os seus voos poéticos, sejam cocriadores de seus mundos. Para que exercitem sua musculatura éticapoética. Para que fortifiquem a sua autoestima e só assim possam voar e cooperar criativamente com o contexto em que vivem. Para que possam parir a si mesmos quantas vezes forem necessárias em sua trajetória de artistas e de vida, pois um fio se conecta ao outro.

Sinto a minha musculatura éticapoética de artistacriadora fortalecida depois de percorrer essa trajetória, e sinto a minha musculatura éticapoética de artistaeducadora e artistapesquisadora formando-se, ganhando corpo, em sintonia, em rede, com a artistacriadora. As oportunidades que se criaram durante o mestrado de manifestar-me como educadorapesquisadora foram essenciais para esse fortalecimento ${ }^{72}$. Elas criaram-se sincronicamente, num fluxo natural, para a $c$ a $m$ t $i$ n $b$ a sejante de estar em relação, de compartilhar os saberes que pulsavam na/da sua experiência.

Vivendo a experiência da sala de aula, aprendendo a dar corpo à minha artistaeducadora, muitas são as questões e reflexões que surgem: como preservar o espaçotempo da experiência dentro de um semestre, de um ano de trabalho? É possível preservar esse espaçotempo na maneira como muitos (a maioria) dos cursos de artes cênicas, sejam universitários ou técnicos, estão estruturados - por exemplo, exigindo uma montagem de peça teatral a cada semestre? Como criar um espaçotempo para nos conectarmos ao pensamento sistêmico, quando normalmente as disciplinas de corpo são separadas das disciplinas de voz, como trabalhar o corpovoz? Qual é a qualidade de artistaeducadora que o contexto em que vivemos hoje necessita?

São muitas questões que pulsam. A experiência do mestrado me deu mais maturidade para lidar com elas, equilibrando dinamicamente as energias Y YNN e INNG Eu respiro as questõesreflexóes; quando surgem inspirações, experimento, proponho, escuto; mas também aceito que o caminho é longo, que as mudanças acontecem em rede, que as cocriamos juntos... A próxima história está sendo vivescrita, a cada respiração, de cada passo, em fluxo e ritmo criativos...
T R A J E T O $S$
E R P
E N T E
É T I C O
$U \mathrm{O} \mathrm{s}$
P
É TIC

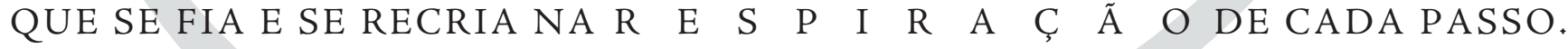

72 Além da oficina ministrada na Colômbia em 2014, no primeiro semestre de 2015, realizei um trabalho de corpovoz, como estágio, em uma das turmas do curso de Artes Cênicas da Faculdade Paulista de Artes, FPA, conduzida pelo professor Marcelo Braga, um amigo que também faz parte do CEPECA. 
Nessa narrativa poéticoinvestigativa, texto sistêmico, de entrelaçamento, que tem a intenção de compartilhar uma experiência e os saberes que nascem e renascem dela, experienciofortaleçoamadureço uma maneira de existir, de gerar e compartilhar saberes, que estejam em harmonia com os pensamentosconhecimentosconceitosexperiências aos quais estou conectada e conectei-me nestes pouco mais de dois anos de mestrado. Desde o início, aceitei o risco de viver essa experiência e pratiquei libertar-me da necessidade de cocriar algo que fosse correto, aceito, aprovado, que estivesse dentro de algum padrão rigidamente preestabelecido e reproduzido. Relacionei-me diariamente com inúmeras questões: Qual é o equilíbrio dinâmico entre o poético e o investigativo? Será que não estou reproduzindo inconscientemente, por medo, por necessidade de ser aprovada, por ignorância, algum padrão de formaconteúdo que é incoerente com a pesquisaexperiência sistêmica que vivencio? Será que estou contestando demais os padrões estabelecidos, precisa tudo isso? Respirei muitos questionamentos, muitos deles ainda pulsam no meu corpovoz... Como, por exemploः será que não estou sendo explicativa demais neste momento?

Certamente, se fosse começar a escrever hoje outra narrativa poéticoinvestigativa, ela seria diferente. Contudo, ela só seria diversa (não sei se melhor ou pior) porque vivi a experiência de escrita desta narrativa que se fia. Reconheço, respirando toda essa trajetória, que foi importante ampliar a minha percepção do todo (da teia), colocar o foco nas relações, fazer esse zoom out, priorizando as relações em diferentes camadas do sistemaprocesso (para alguns, talvez possa parecer que tratei superficialmente de certos tópicos ou assuntos) para, quem sabe, quando florescer o desejo de me arriscar em outros caminhos poéticoinvestigativos, sejam acadêmicos ou não, eu possa mergulhar em algum detalhe ou assunto com essa consciência do todo (da rede) fortalecida. Intuo, e já sinto encarnar, que a minha trajetória como artistapesquisadoraeducadora é o caminho do trabalho corpovoz, e acredito que, com o final do ciclo desse trabalho, abro inúmeras portas e janelas sistêmicas que posso adentrar e aprofundar em pesquisasexperiências e cocriações futuras.

Desejo ainda que todas as experimentações de linguagem que arrisquei realizar nesta narrativa, (mesmo com um espaçotempo justo para dar conta de todos os compromissos do mestrado), com todas as suas falhas e assertividades, desde o trabalho com e a inserção das faixas de vídeo e áudio, até os recursos de aglutinação de palavras, entrelaçamento de rodapés, inspire outras artistaspesquisadoras a criarem os seus padrões e a colaborarem na construção de outros padrões coletivos que ressoem os sentidos e semsentidos das nossas pesquisas práticas em Artes. A próxima história está sendo vivescrita, a cada respiração, de cada passo, em fluxo e ritmo criativos...

A experiência de escrita dessa dissertação também faz parte do movimento de entrar em contato com as o R I G E N S - com os meus processos de origens, com a minha vOZ PoétICA de artistacriadorapesquisadoraeducadora - que é a temática da peça que desaguou com/dessa pesquisaexperiência de mestrado...

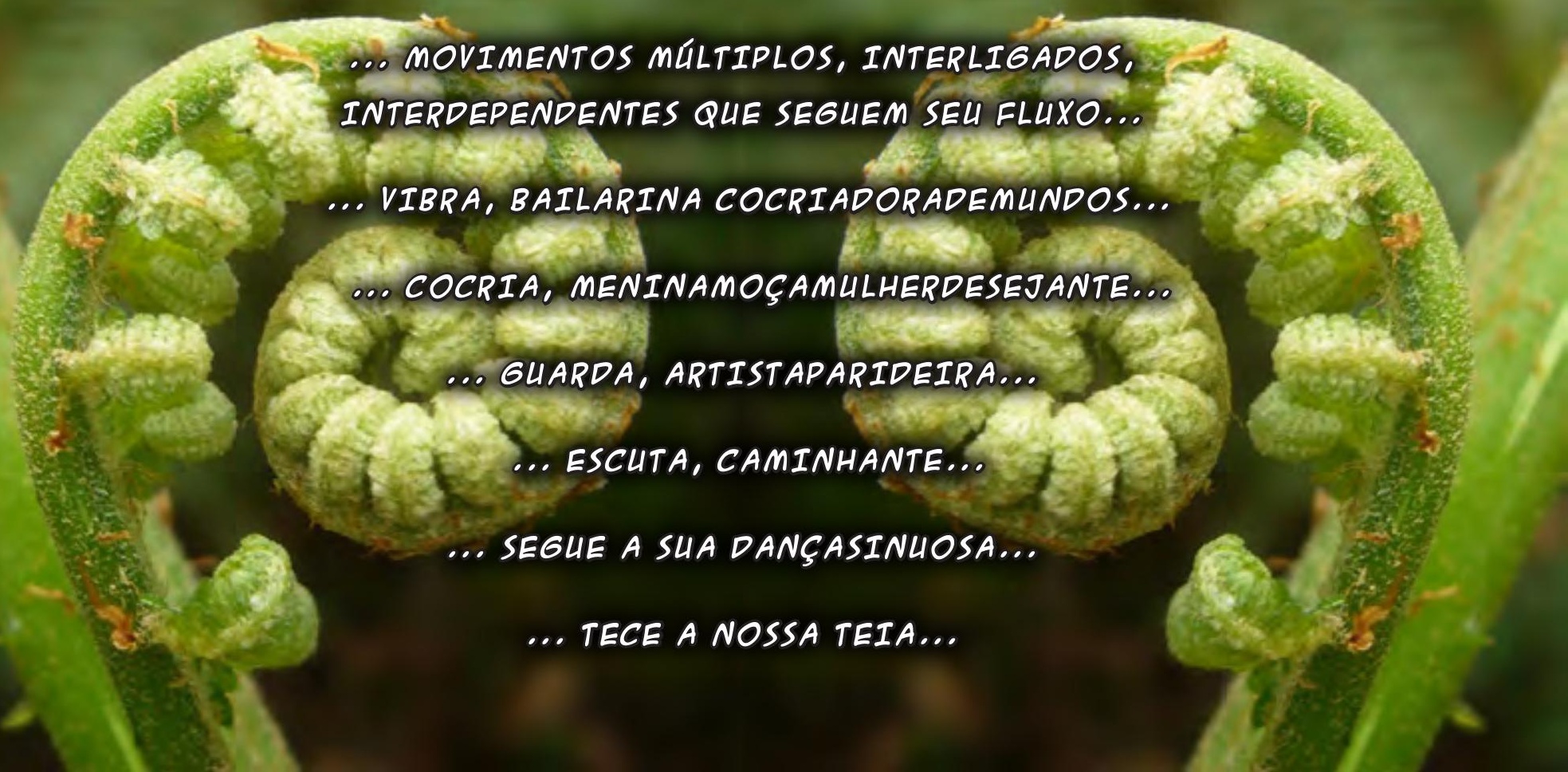


Essa narrativa poéticoinvestigativa, a peça A Próxima História e todas as outras ações que desaguaram com/ dessa pesquisaexperiência são respostas práticas à pergunta:

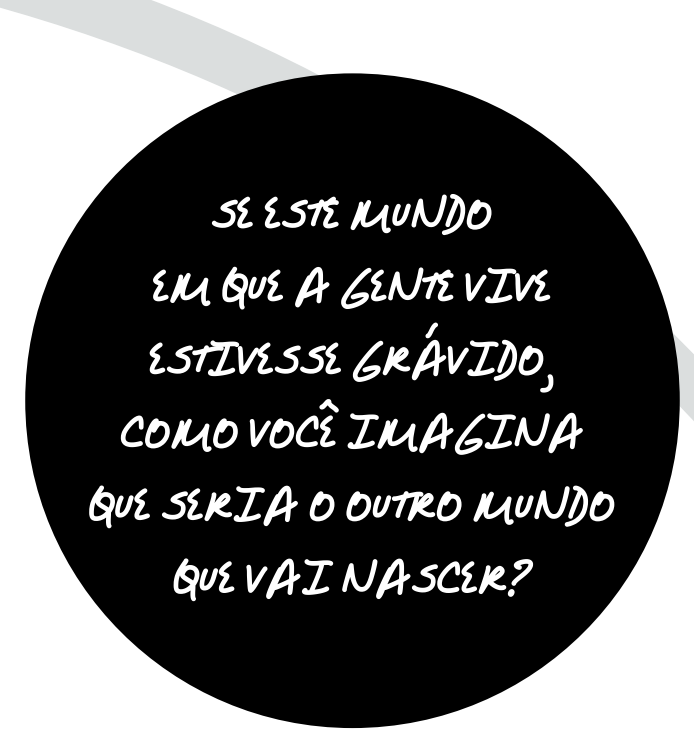

O espaço em branco abaixo é um convite para que você partilhe o seu imaginamento, a sua resposta a essa pergunta, traga a sua voz e cocrie essa pesquisaexperiência, junto, comigo e com o AiVU. Para que possamos seguir pulsando essa experiência em fluxo e ritmo criativos... 
<smiles>C1CCCCCC1</smiles> 


\section{AGRADECIMENTOS}

Gratidão a todas(os) as(os) artistas, vozes, seres criativos - os que vieram antes, junto com e depois de mim - que me inspiram e fazem a vida pulsar em fluxo e ritmo criativos.

À minha família terrena amada, que me deu tempo e espaço para respirar, guardou-me e deu-me suporte para o meu fluir.

Ao AIVU Teatro, espaçotempo de florescimento da minha arte, de encontro com o outro e de encarnação de muitos aprendizados de vida.

Às(Aos) companheiras(os) de cocriação Alencar Martins e Marisa Rebollo, pela confiança, pela presença preciosa de escuta, por compartilhar suas sensibilidades e dons para a cocriação desse trabalho.

Ao meu orientador, Eduardo Coutinho, pela confiança e pela liberdade que tive para percorrer minha trajetória. Também à sua esposa, Rosane Avani Rodrigues, e sua filha, Helena Rodrigues Coutinho, que acompanharam os passos do trabalho e contribuíram com a sua cocriação.

Ao professor Armando Sérgio da Silva, que, com sua generosidade, abriu espaçotempo para o nascimento da minha artistapesquisadora.

A todos os integrantes do CEPECA, espaço coletivo de interlocução, de encontro de diversidades, que fomenta o desenvolvimento de pessoas, arte e pesquisa, que me acolheu, ofereceu oportunidades para a maturação da minha pesquisa e contribuiu muito para a minha formação.

Ao designer e companheiro amado, Marcelo Tomasini, por sua presença amorosa, sensível, talentosa e de cocriação, que contribuiu muito para que essa dissertação encarnasse. Também por todos os abraçosaconchegoscarinhos que me alimentaram e renovaram minha energia em tempos de trabalho intenso, e por todos os feriados e finais de semanas dedicados a esse trabalho.

Ao editor e amigo, Wagner Priante, pela longa parceria de amizade, pela presença sensível, questionadora, cocriadoradesaberes, que contribuiu para que minha escritapensamentoaçãoexperiência amadurecesse durante a feitura deste texto. Também pela sua presença de cocriador em escuta durante todo o sistemaprocesso da peça.

À Janaína Silva, comadre, amiga, irmã de alma, que guardou e germinou comigo a semente deste trabalho. À minha afilhada amada, Nara Dias Gugliano, sementinha que cresceu no meio e junto com essa pesquisaexperiência, ensinando-me sobre o fluir criativo da existência.

A Maria Tereza Urias, Túlio Pezzoni, Gabriel Stippe, Lívia Loureiro, Áurea Teixeira, Ilaise Rabello, Denilson Marques, Kátia Kuwabara, Tide Gugliano, seres criativos que alimentaram esse sistemaprocesso com suas vozespresenças.

A Rodrigo Sarti, Rune Tavares e Leandro Saraiva, amigos e donos da produtora Acere, que confiaram e acolheram o trabalho do AIVU, oferecendo o espaço de que necessitávamos para o início da gestação deste projeto.

Ao Marcelo Braga, amigo e integrante do CEPECA, pela confiança no meu trabalho e por me receber em sua sala de aula como parceira cocriadora.

À Débora Zamarioli, amiga preciosa que, mesmo distante fisicamente, colaborou com este trabalho, compartilhando a sua experiência de artistacriadoraeducadorapesquisadora. 
Aos meus alunos de teatro e de yoga, que permitem que a experiência de cocriação encarne e que os aprendizados necessários para o meu desenvolvimento aconteçam em relação.

A todo o público e amigos que acompanharam e participaram (compartilhando sua vozpresença) do sistemaprocesso de cocriação da peça A Próxima História, ao público que acompanha o AIVU Teatro, que faz com que o trabalho tenha sentido de existir.

Aos professores da pós-graduação da USP: Regina Machado, Zebba Dal Farra, Maria Thais Santos, Marília Velardi e Maria Helena Bastos, com quem fiz disciplinas durante o mestrado, que renovaram a minha confiança na universidade. Também ao professor Renato Ferracini, da UNICAMP, pela interlocução generosa e encorajadora da minha qualificação.

A todos os funcionários e amigos da USP que contribuíram com os pequenos detalhes cotidianos, aqueles essenciais para a cocriação do todo.

À FAPESP pelo financiamento que me possibilitou dedicar tempo e espaço para essa pesquisaexperiência florescer, também pela presença de escuta e abertura para o diálogo, que fez com que reconsiderasse alguns dos meus pedidos.

Vibro muita gratidão!

Esta pesquisa foi realizada com o financiamento da Fundação de A mparo à Pesquisa do Estado de Sáo Paulo (FAPESP). 


\section{REFERENNCIAS BIBLIOGRÁFICAS}

ABREU, Luís Alberto de. A Restauração da Narrativa. In: NICOLETE, Adélia. (org.) Luís Alberto de Abreu: um teatro de pesquisa. São Paulo: Perspectiva, 2011. p. 599-609.

AMADOR, F.; FONSECA, T. M. G. Da Intuição como Método Filosófico à Cartografia como Método de Pesquisa - consideraçóes sobre o exercício cognitivo do cartógrafo. Arquivos Brasileiros de Psicologia, Rio de Janeiro (UFRJ), v. 61, n.1, p. 30-37, 2009. Disponível em: <http://seer.psicologia.ufrj.br/index.php/abp/article/ view/119/286>. (Acesso em: 15 mai. 2015.)

ARGÜELES, José. O Fator Maia. 9 ed. São Paulo: Cultrix, 2009.

ARTAUD, Antonin. O Teatro e seu Duplo. São Paulo: Martins Fontes, 1999.

BÂ HAMPATÉ, A. A Tradição Viva. In: KI-ZERBO, Joseph. (org.) História Geral da África I. Metodologia e pré-história da África. São Paulo: Ática/UNESCO, 1980. p. 181-218.

BARROS, Manoel de. Memórias Inventadas - as infâncias de Manoel de Barros. São Paulo: Planeta do Brasil, 2010.

BENJAMIN, Walter. O Narrador: considerações sobre a obra de Nikolai Leskov. In: BENJAMIN, W. Magia e Técnica, Arte e Política: ensaios sobre literatura e história da cultura. São Pauloः Brasiliense, 1994. p. 197-221.

BONDİA, Jorge Larrosa. Notas sobre a Experiência e o Saber de Experiência. Rev. Bras. Educ., Rio de Janeiro, n. 19, p. 20-28, abr. 2002. Disponível em: $<$ http://www.scielo.br/scielo.php?script=sci_arttext\&pid=S141324782002000100003\&lng=pt\&nrm=iso $>$. (Acesso em: 15 mai. 2015.)

BRIGGS, J. Fractals: the patterns of chaos. New York: Touchstone book, 1992.

BROOK, Peter. A Porta Aberta. 5 ed. Rio de Janeiro: Civilização Brasileira, 2008.

. O Ponto de Mudança. Rio de Janeiro: Civilização Brasileira, 1994.

. Grotowski, el Arte como Vehiculo. Máscara - Cuaderno Iberoamericano de Reflexion sobre Escenologia, Ciudad del México, ano 3, n. 11-12, p. 76-77, jan. 1993.

. O Teatro e seu Espaço. Petrópolis, RJः Vozes, 1970.

BROWN, Christina. A Bíblia do Yoga: o livro definitivo em posturas de yoga. São Paulo: Pensamento, 2009.

CAMARGO, Carlos Augusto Nunes. Minhas Mortes: encontros poéticos suspensos no tempo. 2008. Tese (Doutorado em Artes). Instituto de Artes, Universidade Estadual de Campinas, SP, 2008.

CAPRA, Fritjof. A Ciência de Leonardo da Vinci. São Paulo: Cultrix, 2008.

O Tao da Física. São Paulo: Cultrix, 2006.

. A Teia da Vida. São Paulo: Cultrix, 1996.

. Sabedoria Incomum. São Paulo: Cultrix, 1988.

. O Ponto de Mutação. São Paulo: Cultrix, 1982.

ÉSTES, Clarissa Pinkola. A Ciranda das Mulheres Sábias. São Paulo: Rocco, 2007.

. Mulheres que Correm com os Lobos: mitos e histórias do arquétipo da mulher selvagem. Rio de Janeiro: Rocco, 1994.

FABIÃO, Eleonora. Corpo Cênico, Estado Cênico. Contrapontos, Itajaí, SC., v. 10, n. 3, p. 321-326, set. 2010.

Disponível em: <http://www6.univali.br/seer/index.php/rc/article/view/2256/1721>. (Acesso em: 10 jul. 2014.)

FLASZEN, L; POLLASTRELli, C. O Teatro Laboratório de Jerzy Grotowski. São Paulo: Perspectiva, 2007.

GROTOWSKI, J. Tu Eres Hijo de Alguien. Máscara - Cuaderno Iberoamericano de Reflexion sobre Escenologia, Ciudad del México, ano 3, n. 11-12, p. 69-75, jan. 1993a. 
. El Performer. Máscara - Cuaderno Iberoamericano de Reflexion sobre Escenologia, Ciudad del México, ano 3, n. 11-12, p. 78-81, jan. 1993b.

. Em Busca de um Teatro Pobre. Rio de Janeiro: Civilização Brasileira, 1992.

HERMÓGENES. Autoperfeição com Hatha Yoga: um clássico sobre saúde e qualidade de vida. Rio de Janeiro: Nova Era, 2010.

IYENGAR, B. K. S. A Luz da Ioga. 11 ed. São Paulo: Cultrix, 2010.

JECUPÉ, Kaká Werá. Tupã Tenondé: a criação do Universo, da Terra e do Homem segundo a tradição oral Guarani. São Paulo: Peirópolis, 2001.

KANDINSKY, Wassily. Do Espiritual na Arte. 2 ed. São Paulo: Martins Fontes, 1996.

LEADBEATER, C.W. Os Chakras ou os Centros Magnéticos Vitais do Ser Humano. São Paulo: Pensamento, 2006.

MARTINS, H. H. T. S. Metodologia Qualitativa de Pesquisa. Educação e Pesquisa, São Paulo, v. 30, n. 2, p. 289-300, maio/ago. 2004. Disponível em: <http://www.scielo.br/pdf/ep/v30n2/v30n2a07.pdf>. (Acesso em: 10 jul. 2014.)

MARTINS, José Batista (Zebba) Dal Farra. Notas sobre escuta, ressonância, memória e vocalidade poética. Porto Alegre: Anais do VII Congresso da ABRACE, 2012.

. Palavras Invisíveis. São Paulo: Revista Sala Preta n 9, 2009, p. 183.

. Palavra Muda. São Paulo: SESC, 2014 (no prelo).

. O Testamento da Rapsoda. Barcelona: XVI Seminário Apec, 2011.

MINDLIN, Betty. Nós Paiter: os suruí de Rondônia. Petrópolis: Vozes, 1985. Disponível em: <http://iamausp. wordpress.com/about/ >. (Acesso em: 14 jul. 2014.)

MIKOSZ, José Eliezer. Arte Visionária: representações visuais inspiradas nos estados não-ordinários de consciência (ENOC). Curitiba: Prismas, 2014.

ROLNIK, Suely. Cartografia Sentimental: transformações contemporâneas do desejo. 2 ed. Porto Alegre: Sulina/Editora da UFRGS, 2014.

SANTAELLA, Danilo Forghieri; SILVA, Gerson D'Addio da. Anatomia e Fisiologia aplicadas ao Hatha Yoga. Volume 1ः sistema locomotor. São Paulo: Carthago Editorial, 2011.

WILHELM, Richard. I Ching: o livro das mutações. São Paulo: Pensamento, 2006.

ZAMARIOLI, Débora. Cartografia de um Corpo em Cena: extração e codificação de matrizes corporais através do método Body Mind Centering R. Dissertação (Mestrado em Ảrtes). Universidade de São Paulo, Escola de Comunicação e Artes, São Paulo. 2009. 